\author{
Universidade de São Paulo \\ Faculdade de Filosofia, Letras e Ciências Humanas \\ Departamento de Letras Clássicas e Vernáculas \\ Programa de Pós-Graduação em Literatura Brasileira
}

Maria Rita Sigaud Soares Palmeira

Cada história, uma sentença: narrativas contemporâneas do cárcere brasileiro

São Paulo

2009 


\author{
Universidade de São Paulo \\ Faculdade de Filosofia, Letras e Ciências Humanas \\ Departamento de Letras Clássicas e Vernáculas \\ Programa de Pós-Graduação em Literatura Brasileira
}

\title{
Cada história, uma sentença: narrativas contemporâneas do cárcere brasileiro
}

Maria Rita Sigaud Soares Palmeira

Tese apresentada ao Programa de Pós-Graduação em Literatura Brasileira do Departamento de Letras Clássicas e Vernáculas da Faculdade de Filosofia, Letras e Ciências Humanas da Universidade de São Paulo para obtenção do título de doutor em letras.

Orientador: Prof. Dr. Jaime Ginzburg

São Paulo

2009 


\section{Sumário}

Introdução: p. 7

Capítulo 1 (ou “Cada detento, uma sentença”): p. 23

Capítulo 2 (ou "Ninguém sabe o peso que tem uma grade"): p. 51

Capítulo 3 (ou “Sou o que resulta daí"): p. 88

Capítulo 4 (ou "Vivo em dois mundos simultaneamente"): p. 117

Capítulo 5 (ou "Neste mundo fora do mundo"): p. 145

Anexo: p. 166

Bibliografia: p. 170 


\section{Agradecimentos}

A Jaime Ginzburg, a quem devo a orientação paciente e sempre generosa.

Aos meus amigos do grupo de orientandos, que souberam aliar a seriedade do trabalho intelectual ao amparo amigo, imprescindível para não sucumbirmos aos corredores labirínticos da USP: Cristiana Boaventura, Jayme Costa Pinto, Moacyr Godoy Moreira, Valéria Freitas Pereira e Vinícius Veneziani.

Pela leitura cuidadosa de meu texto de qualificação, agradeço ao professor Marcos Natali e ao professor Márcio Seligmann-Silva (a quem devo também a participação na banca final). A Andrea Saad Hossne e Sérgio França Adorno de Abreu, pela enorme contribuição de suas argüições, às quais este trabalho é desde já devedor. Devo muito a Francisco Foot Hardman: pela participação rigorosa e afetiva em minha defesa de doutorado, mas sobretudo pela presença, desde 1996, em meu pequeno itinerário crítico.

A Miguel Palmeira, meu irmão, “contemporâneo de USP” e estimado interlocutor, e a Fernanda Guimarães, minha cunhada, pelo acolhedor teto paulistano no início desta empreitada e pela força-tarefa ao final dela. A Flávia Trocoli, com quem, desde os tempos de mestrado, venho compartilhando inquietações literárias, porque, entre muitas coisas, foi ela quem, em 2003, primeiro imaginou que a curiosidade em torno desses livros pudesse se tornar um projeto de doutorado. A Ana Raquel Motta de Souza e Alexandre Caroli Rocha, pelos livros, textos e leituras que compartilhamos. A Carlos Minchillo, pelo empenho, ao qual sou muito grata, para que eu obtivesse um semestre dedicado exclusivamente à redação da tese. A Olga Fernández, pelos livros achados e indicados, quando a pesquisa era só uma idéia, e pela amorosa disponibilidade em me ajudar quando a tese já teimava em despontar. A Edu Marin, pela inestimável ajuda com as imagens. Aos amigos de toda hora: Carolina Vaz, Fernanda Raquel, Inaê Coutinho, Laura Bruno, Luiza Marcier, Márcio Varella, Mariana Klinger, Marina Magalhães, Micaela de Góes, Nanda e Celinha Cardoso de Melo, e Rafael Oliva. E também à Wilma e ao Chico Moura, pela ajuda com o laptop e pelo enorme carinho.

Ao Miguel e à Tereza, e também à Mariana, porque, com incansável amor fraterno, se desdobraram para que, nos últimos meses, eu tivesse serenidade para terminar a redação deste trabalho. E, claro, ao João, pela leveza e doçura dos seus quase 17 anos.

A Lygia e Moacir, meus pais, cuja integridade intelectual me faz apostar que a dedicação à universidade e à pesquisa é não só possível como desejável, agradeço o apoio amoroso, as indicações de leitura e a apresentação do mundo.

Ao Flávio Moura, meu melhor leitor, por esta e por outras, porque sim. 
Para Lygia Sigaud, minha mãe, (que partiu quando as palavras ao pé do ouvido terminaram, mas muito antes de a história acabar), porque nomeá-la é, afinal, honrar a sua memória. 


\title{
Resumo:
}

Esta tese analisa quatro livros publicados entre 2000 e 2001, quando foi lançado um grande número de livros escritos por homens encarcerados: Diário de um detento, de Jocenir, Sobrevivente André du Rap (do Massacre do Carandiru), de André du Rap e Bruno Zeni, Memórias de um sobrevivente, de Luiz Alberto Mendes, e Vidas do Carandiru, de Humberto Rodrigues. Sustento que a disposição material desses livros e o modo como a matéria narrativa é enformada sejam indícios de que as narrativas do cárcere brasileiro tragam as marcas dos modos de sociabilidade daquele ambiente, em que se reconhece a condição de preso, mas se almeja o estatuto de escritor.

Palavras-chave: literatura brasileira; prosa contemporânea; prisão; literatura carcerária; testemunho.

\begin{abstract}
:
This work analyses four books published between 2000 and 2001, when there was a boom of "prisoners narratives": Diário de um detento, by Jocenir, Sobrevivente André du Rap (do Massacre do Carandiru), by André du Rap and Bruno Zeni, Memórias de um sobrevivente, by Luiz Alberto Mendes, and Vidas do Carandiru, by Humberto Rodrigues. I argue that the material disposition of these books and the way the narrative substance is constructed are signs that the narratives from Brazilian prisons carry marks of the sociability of that environment, in which one acknowledges the condition of prisoner, but also aims at a writer status.
\end{abstract}

Keywords: Brazilian literature; contemporary prose; prison; prison literature; testimony. 


\section{Introdução}

I.

A escrita a partir da clausura aparece como um tópos na tradição literária ocidental. O silêncio e a solidão costumeiramente associados a esse tipo de trabalho encontrariam nos espaços fechados seu ambiente ideal ${ }^{1}$. A experiência do encarceramento, no entanto, lança por terra qualquer idealização a respeito desse espaço. À clausura forçada, vista muitas vezes como espaço que reuniria condições de trabalho desejáveis ${ }^{2}$, impõe-se a realidade carcerária, tão brutal como aniquiladora.

Os textos produzidos por escritores e intelectuais quando aprisionados costumam ser alvo de atenção das ciências humanas: os Cadernos do cárcere (1948) de Antonio Gramsci, as Recordações da casa dos mortos (1861) de Fiódor Dostoiévski, A balada do cárcere de Reading (1898) de Oscar Wilde, passando pelas não menos canônicas, se consideradas as letras nacionais, Memórias do cárcere (1953) de Graciliano Ramos - é vasta a gama de livros produzidos por escritores e intelectuais a partir da prisão.

Menos difundidos são os livros de homens que, depois de presos, passam a escrever, alçando-se assim à condição de escritores. Ainda que haja exceções, como a de Jean Genet ${ }^{3}$, os livros escritos por homens que se tornam escritores na prisão ou a partir da vida criminosa são bem menos conhecidos do grande público ${ }^{4}$.

No Brasil, há um número considerável de livros feitos por intelectuais a partir da prisão (em sua franca maioria, motivada por suas atividades e posições políticas), mas são poucos - ao menos até o início desta década - os produzidos por homens "do crime", os chamados presos comuns.

\footnotetext{
${ }^{1}$ Ver, particularmente, Victor Brombert, La prison romantique: essai sur l'imaginaire.

${ }^{2}$ Graciliano Ramos conta, em suas Memórias do cárcere, antes de ser de fato preso, mas quando já ouvia rumores de que sua detenção não tardaria: "A cadeia era o único lugar que me proporcionaria o mínimo de tranqüilidade necessária para corrigir o livro [Angústia]" (Memórias do cárcere, v. 1, p. 45). Essa percepção, evidentemente, se altera de todo quando Graciliano é levado à prisão.

${ }^{3}$ Cuja notoriedade possivelmente se deve em muito também, a despeito de suas qualidades literárias, ao estudo que the foi dedicado por Jean-Paul Sartre (Saint-Genet). A esse respeito, ver o artigo de Andrea Saad Hossne "Autores na prisão, presidiários autores. Anotações preliminares à análise de Memórias de um sobrevivente".

${ }^{4}$ Um caso exemplar é o do norte-americano Edward Bunker, cujos livros vêm sendo publicados no Brasil pela editora Barracuda. De Bunker, ver especialmente $A$ educação de um bandido, um romance de suas memórias.
} 
A partir de 2000, livros escritos por homens presos ou recém-saídos da prisão ganharam as páginas dos suplementos culturais dos grandes jornais ${ }^{5}$ e revistas, fosse porque publicados por casas editoriais médias ou grandes ${ }^{6}$, fosse porque parece haver, hoje em dia, maior curiosidade em torno da vida na prisão?.

Este trabalho procura investigar, a partir da análise de quatro volumes de um conjunto bastante mais amplo ${ }^{8}$, livros escritos por homens que, na cadeia, vêem na publicação de seus escritos uma possibilidade de se tornarem autores: Diário de um detento: o livro, de Jocenir; Sobrevivente André du Rap (do Massacre do Carandiru), de André du Rap e Bruno Zeni; Memórias de um sobrevivente, de Luiz Alberto Mendes; e Vidas do Carandiru: histórias reais, de Humberto Rodrigues?.

\footnotetext{
${ }^{5}$ Ver, por exemplo, na ocasião de lançamento de Sobrevivente André du Rap: "Sobrevivente relata massacre do Carandiru" (Folha de S. Paulo, "Ilustrada", 09/09/2002). Ou a resenha do livro de Humberto Rodrigues feita por Hélio Schwartsman: "Vidas do Carandiru: instantâneos expõem o sistema prisional brasileiro" (Folha de S. Paulo, "Ilustrada", 21/12/2002). Ainda, sobre Luiz Alberto Mendes: "Ex-preso usa as próprias cicatrizes" (FSP, "Ilustrada", 20/08/2005) ou as resenhas que lhe dedicaram a escritora Ana Miranda ("Arte e crime em rota de convergência", FSP, "Ilustrada", 17/03/2002) e o sociólogo Sérgio Adorno ("A ciência da tortura", Jornal de resenhas, 12/01/2002). Na revista Istoé gente, saíram, sobre o livro de Jocenir, "Memórias do cárcere: parceiro do rapper Mano Brown, o ex-detento Jocenir lança livro sobre a sua vida atrás das grades" (04/06/2001), sobre o livro de André du Rap e Bruno Zeni: "Sobrevivente André du Rap: ex-detento conta o que viu no Pavilhão 9" (07/10/2002); sobre Vidas do Carandiru: "Vidas no cárcere: livro de jornalista que ficou preso no Crandiru ajuda leitores deprimidos" (29/01/2003). Em $O$ Estado de S. Paulo: "Chega às livrarias Vidas do Carandiru" (11/12/2002); "Ex-detento descreve em livro a rotina da violência" (21/02/2001, sobre Diário de um detento).

${ }^{6}$ Para me ater apenas aos autores abordados nesta tese: a Companhia das Letras publicou dois dos livros de Luiz Alberto Mendes: Memórias de um sobrevivente, 2001, e Às cegas, 2005; a Geração Editorial publicou um outro livro de Mendes (Tesão e prazer, 2004), além de Vidas do Carandiru, de Humberto Rodrigues (2002); a Labortexto Editorial foi responsável pelo lançamento de Sobrevivente André du Rap, de André du Rap e Bruno Zeni (2002) e Diário de um detento, de Jocenir (2001).

${ }^{7}$ As razões hão de ser várias. Regina Dalcastagné, por exemplo, em edição da revista Cult dedicada ao tema, sugere que: "A atração pela escatologia e a literatura de presos talvez supra o prazer de violência do público" (Cult 59, p. 40). É possível apontar ainda o crescimento das discussões sobre criminalidade, política de segurança pública, bem como o surgimento, desde o fim dos anos 90, de bens culturais versando sobre violência e o universo prisional.

${ }^{8}$ Ver, na Bibliografia, a seção "Outros livros do cárcere".

${ }^{9}$ Há, pelo menos, dois casos que merecem ser comentados por seu caráter predecessor, ainda que não façam parte desta pesquisa. O médico Hosmany Ramos tornou-se escritor depois de preso. Descoberto pela prestigiosa editora francesa Gallimard, é, entre os escritores que pertencem a esse segundo grupo (qual seja, o dos que se tornam escritores na prisão), um caso bastante particular: começou a escrever e publicar muitos anos antes e, salvo em seu Pavilhão 9, sua escrita diferencia-se bastante das demais por não narrar em nome de um grupo, não demonstrar compromisso com o que se entende por "coletividade" na cadeia (distanciando-se nesse sentido do grupo que será aqui analisado): "Não faço literatura de presidiário. Sou um escritor preso" (Revista Cult 59, p. 39). Em seu Pavilhão 9, a pedido de outro detento, Milton Marques Viana, um sobrevivente do Massacre do Carandiru, narrou o 2 de outubro de 1992 assumindo a ótica de Viana.

Além dele, o caso talvez mais conhecido seja o de William Carlos da Silva, cujo Quatrocentos contra um: uma história do comando vermelho, publicado em 1991 entrelaça sua trajetória ao processo de formação da famosa facção criminosa carioca. A reedição do livro (por um selo que se dedicaria a essa literatura - a Labortexto Editorial) em 2001, ano em que saem outras publicações ligadas à vida na prisão, revela seu
} 
O que provocava, desde o início da pesquisa, minha reflexão não era que escrevessem $^{10}$, mas que enxergassem na publicação de seus livros a reinserção, que buscassem legitimar-se aos olhos da sociedade a partir de um discurso deslegitimado previamente, o de homens encarcerados ${ }^{11}$. A escrita implicaria transformação. Nesse sentido, a escrita parecia assumir uma dimensão ética.

Alguns deles traziam relatos de constrangimentos físicos e morais, outros, embora não se furtassem a contar as violências a que seus autores haviam sido submetidos nas prisões, dedicavam boa parte do texto à narrativa de suas histórias de vida. Uniam ao relato fotografias, reproduções de cartas recebidas e enviadas, fragmentos de textos de sua autoria (em muitos casos, letras de rap); mas também reflexões sobre o sistema carcerário brasileiro, glossários, contos, poemas.

Esses livros comungavam nos valores ali expressos, que, por sua vez, remetiam ao ambiente de onde provinham - a prisão. Assim, o eixo das histórias narradas parecia ser a manutenção desses valores, o que ajudava a caracterizá-los como dignos de reunião para fins de análise. O que se encontrava ali como matéria narrativa construída a partir de qualidades como lealdade, humildade, solidariedade, professadas à exaustão por seus autores, era na maior parte das vezes o relato da experiência na prisão (a vida "no crime"; eventualmente, suas motivações; a saudade de casa; a dureza do cárcere;), mas também o rememorar da vida para além do "peso da grade".

Despertava-me curiosidade a maneira como seus autores, na maior parte das vezes provenientes dos estratos menos favorecidos da sociedade, lançavam mão de um objeto com o qual pareciam não ter muita familiaridade - o livro - e o transformavam,

caráter precursor. Sua prosa, bem como suas escolhas por privilegiar o texto em detrimento de fotos, cartas etc., se aproxima da de Luiz Alberto Mendes.

${ }^{10}$ Nos livros há sempre referência à escrita e à leitura - e até mesmo em relação ao papel que essa atividade desempenha no dia-a-dia da cadeia: "No campo [de futebol] todo mundo se encontrava, combinava de passar um no barraco do outro. Você ia no barraco de um companheiro, ele mostrava um jornal da quebrada dele ou mostrava o que tava escrevendo, já pegava amizade. Era uma troca no dia-adia" (Sobrevivente André du Rap, p. 50).

11 "O automatismo [de aceitar que textos escritos por escritores a partir da experiência prisional sejam literários] se rompe e se expõe quando o objeto enfocado não ocupa de antemão o panteão literário. Nesse caso, já não se trata mais de autores (e personagens e narradores) na prisão, mas de presidiários autores, ou seja, aqueles nos quais a condição de encarcerado precede e mesmo preside a da escrita. O que se coloca em xeque, então, não será apenas a natureza da representação e a matéria representada, mas também, e sobretudo o acolhimento crítico a ela" (Andrea Hossne, "Autores na prisão, presidiários autores", p. 129). 
reorientando-o em sua disposição material, em função de certas percepções que diziam muito sobre a vida no cárcere. Esse ajuste era feito de maneira bastante peculiar, uma vez que não se abandonava uma concepção previamente estabelecida do livro ou do que significa contar uma história. Assim, se estavam ali para narrar a maneira como as suas trajetórias individuais entrelaçavam-se à história de violência dos presídios brasileiros, $\mathrm{o}$ que até então não fora feito, era preciso dar conta disso partindo de um modelo em tudo oposto a sua situação: ao romance burguês e sua solidão constitutiva, opunha-se uma escrita formada a partir de condições precárias e violentas de concentração humana, como as reveladas pela superlotação das celas, os acertos de contas entre presos e a vigilância nem sempre distante das forças do Estado.

Chamava ainda atenção o que resultava desse enfrentamento, quase uma forma em mosaico, provocada pela reunião do texto a outros elementos que se assumiam igualmente narrativos, como as cartas e as fotos. Os livros traziam, em sua maioria, não só o texto propriamente, como também fotografias, letras de música, glossários, cartas recebidas e enviadas, o depoimento dos seus próximos. Parecia que a escolha do livro como meio privilegiado de expressão determinava que, ao fazê-lo, fosse preciso transformá-lo de modo a dotá-lo de singularidades que, a alguém que se dispusesse a ler o sem-número de títulos editados, não escapariam como índices de formação de um conjunto. Em maior ou menor medida, as narrativas a partir da prisão obedeciam a uma disposição que remetia à história ali enunciada - ainda que lançassem mão do livro para fazê-lo.

Era preciso verificar se também na escrita se manifestava essa primeira ambivalência reveladora da adesão ao mundo exterior às grades (visível na escolha do livro em ambiente não especialmente letrado) e interior a elas (perceptível na lealdade aos valores compartilhados e na conduta assumida).

Diante desse conjunto, era possível perceber a recorrência do que se poderia considerar um certo padrão: seus autores mobilizavam, ao recuperar fragmentos da história vivida no cárcere, formas de atestar que aquilo tudo havia, de fato, se passado com eles. Ao menos esta era a hipótese mais plausível quando se constatava o temor, reiteradamente expresso, de que o que ali se contava não fosse levado a sério ${ }^{12}$.

\footnotetext{
${ }^{12}$ Alfredo Bosi, em artigo sobre as Memórias do cárcere, de Graciliano Ramos, chamou a atenção para o fato de o testemunho "quer[er]-se idôneo, quer[er]-se verídico, pois aspira a certo grau de objetividade", ao mesmo tempo em que não escapa à idéia de que o que se tem ali é obra de uma testemunha, impondo à sua história um "foco singular de visão e elocução", portanto, de subjetividade. ("A escrita do testemunho em
} 
A fim de que a respeito daqueles relatos não pairassem dúvidas - uma necessidade de cercar-se de todas as maneiras da pergunta que se fazia premente naqueles indivíduos que começavam a reivindicar o estatuto de autores: "mas quem vai acreditar no meu depoimento?" ("Diário de um detento", Jocenir/ Mano Brown) -, recorria-se a depoimentos e fotografias que recuperassem as trajetórias narradas. A sensação de serem alvos de desconfiança de seu eventual público leitor se fazia presente nessas histórias - fruto certamente da sensação da intraduzibilidade da violência a que foram submetidos, mas também do sentimento de exclusão, este muito anterior - na maior parte das vezes - à experiência do cárcere, já que a maioria da população carcerária provém das camadas menos favorecidas da sociedade: é pobre, moradora de periferia ou favela e, sobretudo, pouco letrada. Salvo raras exceções, essas narrativas mostravam que a palavra escrita parecia pertencer ao outro, não a eles - o outro de quem se distanciam pelas diferenças sociais e pelas grades. Era preciso tomar posse dela e adequá-la a seus propósitos, afinal, a palavra escrita é, antes, do mundo que o condenou e de suas instituições, o mundo dos "homens livres".

Esse volume de títulos, como aqui já se disse, desiguais em muitos aspectos, começou a ser publicado com certa freqüência. Passou-se a chamar de "literatura carcerária" ${ }^{13}$ o que autores como Jocenir, Luiz Alberto Mendes, Humberto Rodrigues, entre outros, escreviam.

Além disso, uma vez publicado seu primeiro livro, esses homens passaram a reivindicar para si o título de escritores. Quando saíssem da prisão, ou mesmo enquanto pagavam a sua pena, estariam longe "do crime" e se dedicariam à escrita (daí a aludida dimensão ética que essa narrativa parecia assumir).

O que ali se notava era um imperativo de relatar a dureza da experiência carcerária - as humilhações, torturas, falta de condições básicas de higiene e de acesso aos benefícios previstos em lei -, aliado a certo sentido de missão (presente principalmente entre aqueles que sobreviveram a rebeliões violentas ou ao Massacre de $1992^{14}$ ). Por outro lado, tal

Memórias do Cárcere”, p. 222).

${ }^{13}$ Ver, por exemplo, Márcio Seligmann Silva, "Violência, encarceramento, (in)justiça: memórias de histórias reais das prisões paulistas". Andrea Hossne, em seu "Autores na prisão, presidiários autores. Anotações preliminares à análise de Memórias de um sobrevivente", prefere referir-se a esses livros (particularmente o de Luiz Alberto Mendes) como uma expressão da "literatura marginal".

${ }^{14} \mathrm{Ou}$ "Massacre do Carandiru", quando pelo menos 111 presos foram mortos pelas forças policiais do Estado de São Paulo, durante invasão da Casa de Detenção do Carandiru. 
necessidade vinha acompanhada de uma incapacidade de narrar com precisão os piores momentos vividos na prisão.

Pareciam escrever (e também aqui era possível perceber uma dupla intenção) tanto aos jovens cuja origem se assemelhasse à sua (a fim de que estes não seguissem os maus exemplos, não "caíssem no crime”) quanto a um público a eles estranho - aquele capaz de inseri-los como autores, legitimar sua escrita.

Antes de passar ao próximo item, é preciso lembrar que esses autores, muitos dos quais assumem a condição de "sobreviventes", trazem em suas narrativas a idéia de que são mensageiros da realidade carcerária, tarefa à qual não podem se furtar ${ }^{15}$. Contudo, há uma ambigüidade no modo de apresentar-se: o foco é contrário ao "sistema" - categoria em que aglutinam as forças que lhes seriam contrárias -, mas, como uma espécie de redenção, uma maneira de sair da "vida no crime" ou, antes, da vida simplesmente marginal, apostam na nova profissão - a de escritor -, o que os colocaria dentro do "sistema" combatido. Esse aproximar-se e afastar-se do "inimigo" contribui para entender a complexidade desses livros.

Como escrevem esses autores? Como representam em seus relatos a experiência do cárcere? Como se colocam frente à literatura, isto é, adotam os modelos tradicionais de escrita ou procuram rompê-los? O que, finalmente, os distingue como narradores? Como a elaboração que fazem da experiência do cárcere atua na constituição dessas obras?

Este trabalho procura discutir essas questões, cujos desdobramentos apresento no próximo item, em Memórias de um sobrevivente (Luiz Alberto Mendes), Diário de um detento: o livro (Jocenir), Sobrevivente André du Rap - do Massacre do Carandiru (André du Rap e Bruno Zeni) e Vidas do Carandiru: histórias reais (Humberto Rodrigues). A escolha desses títulos, um recorte na relativamente extensa literatura produzida a partir do cárcere, se pautou pelo desejo de estabelecer um pequeno conjunto de textos que, a despeito de suas similitudes formais e da experiência comum de seus autores, preservassem

\footnotetext{
${ }^{15} \mathrm{~A}$ idéia de que não possam escapar à tarefa dolorosa perpassa os volumes estudados (sobretudo nos livros de Jocenir e de André du Rap) e faz lembrar a observação de Michael Pollak e Natalie Heinich, em seu estudo sobre os campos de concentração, quando discutiam o caráter autobiográfico de uma experiência coletiva: "o acesso à palavra pública e à publicação de uma vida individual não depende da notoriedade da pessoa, mas de seu estatuto de representante de um grupo [aqui, dos deportados] e de porta-voz de uma causa (transmitir a experiência da impensável barbárie e lutar contra ela)" ("Le témoignage", p. 13 [tradução minha]).
} 
particularidades. Além disso, procurei obedecer ao critério de que fossem os próprios presos os autores de seus relatos ou que, ao menos, estes tivessem se originado a partir de uma necessidade deles, isto é, em que ficasse clara a exigência do narrar como pertencente aos sujeitos daquelas narrativas.

\section{II.}

Algumas das questões que nortearam este trabalho merecem maior detalhamento ainda nesta parte.

A escrita a partir do cárcere se funda sob o signo de várias ambivalências que parecem remeter ao modo de sociabilidade das prisões. É possível estabelecer um esquema que funcionaria assim: a sociedade (o mundo dos "homens livres") recusa aos presos condições mínimas de cumprimento das penas, mas, ao mesmo tempo, tem curiosidade pela experiência carcerária e cria uma demanda por suas narrativas (admitindo-se aqui que a circulação dos livros não se dê apenas dentro dos presídios). Os homens encarcerados que escrevem, por sua vez, querem opor-se a essa mesma sociedade (que os expõe às piores condições de cumprimento de sua pena), ao "sistema", mas querem também de algum modo pertencer a esse mundo, cujas leis reconhecem em sua normatividade.

Essa literatura, embora (ou porque) feita por homens enclausurados, traz uma tentativa de interlocução, nem sempre explícita, com a sociedade que privou seus autores de liberdade. Isso se percebe quando, mesmo encarcerados por um "sistema" que julgam injusto, os autores o vêem como detentor de um conjunto de regras claramente identificáveis em seus textos e às quais se reportam com certa freqüência: não é permitido matar, roubar, ser cruel, injusto. Apesar de não as terem seguido quando em liberdade e, em alguns casos, mesmo quando presos, incorporam-nas, cada um a seu modo, a sua escrita. Haveria, portanto, o que, em meu trabalho, chamo de adesão aos códigos dos homens livres, a partir do olhar duplo do narrador.

O confinamento, contudo, faz com se criem leis próprias àquele universo, as leis do crime, as leis dos presos - regrário que se impõe pela palavra empenhada. Os valores exaltados nos textos que aqui analiso são também ambivalentes. Quando legitimam a 
conduta humilde, quando condenam a soberba, quando prezam a coletividade e a fraternidade, ecoam, para além do discurso de cunho religioso e também por causa dele, o mundo dos homens livres.

A escrita a partir do cárcere deixa revelar, portanto, uma adesão ambivalente a esses dois universos, o que de algum modo repõe no texto a relação estabelecida com a sociedade da qual estão apartados - ou com o "sistema" -, responsável pelas condições precárias dos presídios, bem como por submetê-los a experiências-limite, mas também capaz de nomeálos escritores.

Essa junção do ambiente majoritariamente iletrado com o mundo dos livros produz uma nova configuração material da escrita, provavelmente, reflexo do pouco crédito dado à palavra desses homens (daí a necessidade de cercar-se das "provas" materiais da experiência - as fotos, as cartas, os depoimentos de outras pessoas) e à dificuldade de torná-la crível (em razão, por um lado, da introjeção do estigma de presidiário; por outro, do estigma que lhes é de fato atribuído); mas reflexo também de um conjunto de condutas e valores que devem ser expressos - a lealdade, a fraternidade etc. Os princípios partilhados pelos enclausurados contribuem para dar forma à sua escrita. Novamente, se repõe, desta vez na formalização material do livro, o modo como essa escrita e seus autores se relacionam tanto com o mundo além das grades quanto com o mundo da prisão.

A escolha do romance ${ }^{16}$, aqui entendido como forma híbrida e problemática ${ }^{17}$, cuja origem remonta à expressão da individualidade e dos valores burgueses, é em si um modo de singularizar a si e a experiência. Porém, como a identidade se liga, aqui especialmente, à defesa das normas compartidas, é preciso de algum modo dar conta disso, já que a prisão impossibilita ignorar a coletividade.

Como ocorre em narrativas produzidas a partir de confinamento coletivo, há aqui também o questionamento do modo de formalizar, pela escrita ou pela disposição dos elementos que compõem o livro, o que é particular e o que é do grupo. A experiência traz uma dimensão coletiva, mas quem narra a viveu de modo obviamente particular $^{18}$. No

\footnotetext{
${ }^{16}$ Romance de teor autobiográfico, testemunhal ou autoficcional, uma vez que todos eles assumem narrar a própria experiência prisional.

${ }^{17}$ Ver Fredric Jameson, Marxismo e forma, p. 136.

18 A esse respeito, é iluminadora a observação de João Camillo Penna sobre o testemunho quando trata de "estatuto coletivo do sujeito" ou de "singularidade plural" ("Este corpo, esta dor, esta fome: notas sobre o testemunho hispano-americano", p. 313 e 320, respectivamente).
} 
entanto, chamar a atenção em demasia para o estatuto individual recusa a própria idéia de coletividade a que um homem deve aderir quando chega à prisão. De modo geral, esses autores vêem sua narrativa encrespar-se diante disso - daí um movimento que observei nos textos e a que chamei, com fins meramente indicativos, de singularização e coletivização.

Além de explorar a conformação material dada a esses livros (leia-se: como são dispostos os elementos formadores do mosaico), procurei perceber em que medida essa dupla adesão se revelava também na escrita. Valer-se do uso de clichês, por exemplo, se revelaria fundamental na construção narrativa de alguns desses volumes. Afinal, tal emprego sugere a adesão ao que esses autores reconhecem como código escrito dos homens "livres", como boa escrita, mesmo se não os percebem como vocabulário gasto. As gírias, as expressões "da cadeia", ao contrário, constituem linguagem própria. ${ }^{19}$ A junção que advém dessa mistura de registros repõe para o nível da escrita o que já se percebe na apropriação do livro como objeto e que recupera o modo como o interno se relaciona com o mundo exterior.

\section{III.}

Apesar de crescente, o interesse por essas obras é ainda bastante restrito. Salvo algumas dissertações de mestrado ${ }^{20}$ e artigos em periódicos ${ }^{21}$, um estudo mais detido sobre esses livros ainda estava por ser feito.

A tese está montada em cinco capítulos. Os quatro primeiros dedicam-se ao exame dos livros. Optei por discutir separadamente cada um dos textos. Com isso, pude apresentar as questões conforme surgissem no enfrentamento analítico. Nesse sentido, a tese inclui o seu próprio memorial. Cada capítulo serve de base ao seguinte. Se essa escolha evidencia

\footnotetext{
${ }^{19}$ Karl E. Schollhammer, em seu artigo "Memórias de delinqüência e sobrevivência", atribui o excesso de clichês "à expressão da impotência do testemunho" (p. 142). Acredito que o emprego dos lugares-comuns, longe de resultar em uma perda, se observado junto ao uso da "linguagem da cadeia", reverte-se em arranjo formal interessante e que poderia ser visto à luz da dúplice adesão a códigos de escrita e de conduta de que venho tratando.

${ }^{20}$ Ver, especialmente, Adauto Locatelli Taufer, Do factual ao ficcional: memória, história, ficção e autobiografia nas Memórias de um sobrevivente, de Luiz Alberto Mendes (UFRGS); e Pablo Augusto Silva, O mundo como catástrofe e representação: testemunho, trauma e violência na literatura do sobrevivente (Unicamp).

${ }^{21}$ Ver, especialmente, os artigos de Márcio Seligmann-Silva, que, com certa constância, tem se dedicado ao assunto - "Novos escritos dos cárceres: uma análise de caso. Luiz Alberto Mendes, Memórias de um sobrevivente"; "Violência, encarceramento, (in)justiça: memórias de histórias reais das prisões paulistas" -, bem como, de Karl Erik Schollhammer, op. cit., e de Andrea Saad Hossne, op. cit.
} 
um percurso crítico, também pode se revelar por vezes arriscada: como os livros trazem questões semelhantes, abordá-las em quatro momentos poderia ser visto como procedimento repetitivo. Não se trata disso. Examiná-los de imediato pelo que trazem de próximo diluiria suas especificidades e tornaria as questões que aponto no Capítulo 5 menos claras. As repetições, ademais, são elementos característicos à literatura produzida a partir do cárcere - incorporá-las ao trabalho recupera o próprio objeto. Os fios condutores desta tese - a apropriação do objeto livro, a adesão a códigos de escrita e comportamento dúplices, a reivindicação do estatuto de autor, a perspectiva da escrita como transformação - aparecem assim como se apresentam em cada história.

No primeiro capítulo, analiso Diário de um detento, de Jocenir. Tento mostrar como haveria um "olhar duplo" por parte do narrador. Por olhar duplo, algo que já venho perscrutando nesta introdução, entenda-se uma adesão ambivalente aos códigos carcerários (dos homens presos) e ao dos homens livres. Procuro mostrar como a escolha vocabular e a estrutura sintática ora revelavam uma incorporação do etos prisional ${ }^{22}$, ora mostravam-se mais próximas ao que se compreende como pertencente ao mundo dos homens livres. Essa ambigüidade narrativa constitui a particularidade do livro de Jocenir e - aí reside a minha aposta - do conjunto pesquisado de narrativas a partir do cárcere. Entrelaçando essa preocupação à da escolha do livro como meio privilegiado de expressão, procuro mostrar como ela obedecia a uma mesma "lógica": o livro, como objeto de um universo letrado, pertenceria ao mundo dos "homens livres", mas a apropriação que Jocenir fazia dele transformava-o em objeto igualmente pertencente ao cárcere, dotando-o de particularidades que expressavam essa ambivalência formal.

Sobrevivente André du Rap, de André du Rap e Bruno Zeni, é objeto do Capítulo 2. Analiso-o como a convergência de duas urgências narrativas de origem diversa, da qual resulta um livro ambivalente não apenas em sua adesão ao discurso externo e interno à cadeia, mas também na dupla autoria de sujeitos com trajetórias distintas e que trazem para a linguagem essas diferenças, em que a prisão, ainda assim, se impõe como elemento estruturador.

\footnotetext{
${ }^{22}$ Compreendido como o conjunto de valores e condutas reconhecidos como legítimos dentro da prisão.
} 
No Capítulo 3, apresento as reflexões sobre Memórias de um sobrevivente, de Luiz Alberto Mendes. Esse livro, em suas quase 500 páginas, narra a história da vida de Mendes, desde a infância até meados da década de 1970. É a narrativa de sua história na prisão, mas também antes dela. Para além do fôlego de escrita, as suas Memórias de um sobrevivente diferenciam-se dos outros livros em sua conformação, ainda que esteja presente a dupla adesão aos códigos externo e interno à cadeia. Não aparecem, como nos outros três livros que estudo, reprodução de cartas, nem fotos, tampouco seu autor disponibiliza espaço para declarações dos "aliados". Memórias de um sobrevivente é fruto da dupla experiência de Mendes na vida criminosa, encarcerada (por um lado), e na vida letrada (por outro). Procurando construir um personagem que ultrapassa, sem exatamente negar, o que o ambiente prisional reconhece como legítimo, até porque escolhe narrar também a sua vida anterior à prisão, afasta seu texto do de outros autores egressos do cárcere. Faz isso, contudo, sem negar sua experiência, o que seria, sob a ótica da prisão, um desvio como preso que foi e que ainda era no momento da elaboração e publicação do seu texto.

O Capítulo 4 versa sobre o último dos livros estudados: Vidas do Carandiru, de Humberto Rodrigues. O publicitário, preso aos 67 anos, conta a sua experiência como detento. Rodrigues, ainda que faça questão de se apresentar como observador diferenciado, dedica grande espaço às histórias ouvidas enquanto esteve preso, o que o aproximaria dos outros livros analisados. Seu Vidas do Carandiru apresenta diário, glossário e uma espécie de elucidário das tatuagens feitas pelos presos; faz a crítica ao sistema penitenciário que os outros volumes também se esmeram em fazer; bem como o relato de seu inferno pessoal. A maneira como mobiliza o conhecimento livresco (nas constantes epígrafes, citações, notas de rodapé) e, a partir dele, tenta escapar à condição de preso esbarra em como o seu livro está amoldado a um fazer narrativo característico do cárcere.

No capítulo 5, tendo esmiuçado os quatro livros, passo ao que seriam as considerações finais, quando proponho uma leitura para a escrita prisional, destacando-a de outras produções que surgiram paralelamente.

Com o avançar da pesquisa, pude perceber que se, por um lado, essa escrita não negava a experiência prisional e miserável, assim como não deixava de atacar a "sociedade", o "sistema", responsável, afinal, pelas más condições de cumprimento da 
pena, por outro, essa nova expressão literária parecia estabelecer no plano textual uma cumplicidade com essa mesma sociedade e sistema recusados, porque capazes de alçá-los ao estatuto de autor e tirá-los do passado marginal (nesse sentido, esses autores parecem ver na escrita um caminho para a redenção social). A própria escolha do livro indicava essa aderência, que poderia se dar a um só tempo em duas vias: a preservação da identidade carcerária e a necessidade de esquecê-la para poder continuar.

A tese investiga, portanto, essa ambivalência, que pode ser vista em diversos níveis, mas que remonta a uma duplicidade que se poderia chamar de original ou constitutiva e que diz respeito à relação que esses livros estabelecem entre o mundo interior à prisão e o mundo exterior a ela. A escrita prisional procura ser fiel aos modos de sociabilidade do cárcere, o que implica o respeito aos códigos de conduta estabelecidos pelos próprios presos, bem como o respeito reiterado pelos valores ali compartilhados.

$\mathrm{Na}$ construção de suas narrativas, esses escritores procuram evidenciar a importância que teve a escrita durante a estada na instituição penal: é ela que irá diferenciálos dos demais, garantindo-lhes um papel privilegiado no hierarquizado jogo das cadeias. Além disso, a escrita aparece como saída para vencer o tempo e evitar confusões com outros presos.

Jocenir, autor de Diário de um detento, conta que, enquanto estava preso, aos poucos ia sendo reconhecido por seus pares como alguém que sabia fazer versos (nesse sentido, os outros presos legitimavam sua escrita, quando começavam a lhe pedir que escrevesse versos e cartas para a família deles) e por ele mesmo (quando constrói para si a imagem de alguém que tem intimidade com as palavras, em função de um "dom" que outros também enxergam nele).

A facilidade com a escrita, ao mesmo tempo em que cria uma identidade prisional (a de alguém que sabe escrever bem, é capaz de fazer versos, mas que continua detido), destaca-o do conjunto de detentos, aproximando-o da carreira almejada de escritor. Nesse sentido, aproximando-o também do mundo exterior à prisão. Além disso, trazer a escrita para o proscênio aparece como possibilidade de reintegração ao mundo além-grades ${ }^{23}$.

\footnotetext{
${ }^{23}$ Essa dimensão da recuperação é explorada de maneira bastante aguda no trabalho de José Ricardo Ramalho sobre o Carandiru como fazendo parte do discurso dos presos: "A viabilidade da recuperação se afirma pela prática do trabalho, pela manutenção ou restauração de laços familiares, pelo acesso à instrução, pela profissionalização, valores aos quais o preso adere, por 'esforço' pessoal, voluntariamente" (Mundo do crime: a ordem pelo avesso, p. 112).
} 
Quando Jocenir afirmava que as experiências eram as mesmas (e, nesse caso, ele sendo um "homem de letras" é capaz de traduzi-las para o papel, o que o singulariza nesse conjunto), sinaliza que há uma experiência comum em jogo e que seu livro é o relato de "seu inferno", que, por sua vez, é muito próximo ao de tantos outros.

A desenvoltura com as palavras the rende, então, para além da fama de homem das letras, um ofício - raro na cadeia e reconhecido como digno também fora dela. Assim, o tornar-se escritor e o vislumbrar de uma recuperação por meio desse novo estatuto apontam para fora do cárcere, embora, para fazê-lo, Jocenir precise narrar da e sobre a cadeia.

"Há também o fato de que, boa ou ruim, esta é a minha história. Quer dizer: sou o que resulta daí" - escreve Luiz Alberto Mendes. "Mas eu não tenho vergonha de ser expresidiário, não. É a minha história. Acho que é por isso que essa história deve ser contada da maneira que aconteceu, porque é a história de cada um, ninguém se livra dela, ninguém tem outra pra contar" - pontifica André du Rap.

Tanto no que diz Mendes como no que diz André percebe-se um modo ambíguo no tratamento da própria história. Ambos repetem "é a minha história", no que parecem expressar certa altivez. Mas a ressalva é feita. Mendes coloca em questão se se trata de uma história "boa ou ruim", sugerindo que ele seja o "resultado" disso - portanto, se hoje ele escreve sobre o que houve do modo como escreve, é porque passou por tudo aquilo. Ao mesmo tempo em que expressa orgulho por sua trajetória de mudança, conversão, sugere saber que não pode recusar a pecha de "ex-presidiário" (ou, no caso de Mendes à época da publicação desse seu primeiro livro, de presidiário), dono de uma história que pode ser vista como boa, pelo que dela resultou, mas também ruim, pelos muitos percalços enfrentados.

André é mais explícito e diz "Mas eu não tenho vergonha de ser ex-presidiário, não". O uso do "mas" já sugere um discurso contra o qual tenta se insurgir - o de que ele talvez devesse ter vergonha de ser ex-presidiário.

Logo depois, justifica a necessidade de contar a sua história: "porque é a história de cada um" - num elogio às trajetórias no que elas têm de único -; "ninguém se livra dela" o verbo é especialmente digno de nota porque remete não só à idéia de livramento da pena (e, nesse caso, a própria história é também uma pena), mas também à idéia de que de outras coisas se pode escapar, mas não da própria história. "Ninguém tem outra pra contar", 
sentencia André, sugerindo, no que se mostra muito fiel aos ditames do cárcere, que é impossível fugir ao vivido quando se está na prisão.

Humberto Rodrigues, autor de Vidas do Carandiru, assim se refere à decisão de escrever: "Subitamente, não me sentia mais como um preso, mas como um pesquisador que havia se proposto a permanecer durante algum tempo num local de privações para elaborar um livro". O preso é, aqui, colocado em oposição ao pesquisador. A escrita funcionaria, portanto, como modo de não assunção da identidade prisional, embora Rodrigues não tenha como se furtar a ela.

No Capítulo 5, exploro a idéia de que a saída pela escrita poderia fazer parte do que Erving Goffman chamou de uma forma de o indivíduo estigmatizado "corrigir" a sua condição, "dedicando um grande esforço individual ao domínio de certas áreas de atividade consideradas, geralmente, como fechadas a pessoas com o seu defeito" 24 . O investimento na escrita seria, desse modo, uma maneira de tentar fugir ao estigma, mas, no que diz respeito à literatura prisional, também de reafirmá-lo.

Estou aqui considerando o estigma, não como um atributo depreciativo, mas como "uma linguagem de relações", já que "um atributo que estigmatiza alguém pode confirmar a normalidade de outrem, portanto ele não é, em si mesmo, nem honroso, nem desonroso". O "estigma" precisa ser entendido, no contexto dessa produção, como marca de reivindicação autoral e no modo como se concatena à ambivalência constitutiva que mencionei.

Ao depender das instâncias de legitimação, para que sua trajetória (ou "carreira moral" para continuar com Goffman) possa ser contada e transformada (afinal, tornam-se escritores), esses autores fazem um movimento de diálogo com o mundo exterior à prisão, que, por sua vez, pode reconhecer aquele discurso, mas que dificilmente o entenderá além da perspectiva prisional.

Na tentativa de livrar-se da pecha de presidiário, esses homens procuram construir para si um novo caminho, por meio da escrita, quando se tornam autores. No entanto, a experiência prisional é tão extremamente disciplinadora que, como diz Jocenir, "um homem nunca é o mesmo depois da prisão". Por isso, eles não podem se furtar a narrar a partir da prisão, mesmo se já fora dela.

\footnotetext{
${ }^{24}$ Erving Goffman, Estigma: notas sobre a manipulação da identidade deteriorada, p. 19.
} 
Narrando a partir da prisão, constroem uma perspectiva que, ao mesmo tempo em que dialoga com os pares, confirmando o pertencimento ao grupo, procura escapar à condição limitadora. A escrita produzida a partir da prisão revela oscilação entre o sentimento de tomar parte em um coletivo (quando faz valer na sua escrita o conjunto de valores - solidariedade e fraternidade, por exemplo - e condutas - não delatar, não testemunhar, não deixar de pagar dívidas, não deixar de cumprir as tarefas etc. - próprios ao cárcere, ou quando é capaz de solidarizar-se com o sofrimento alheio e escrever a história do companheiro, colocar em seu livro uma foto sua, ou simplesmente louvá-lo como sujeito digno) e de não fazer parte desse grupo (quando se torna um escritor publicado: aqui, afasta-se do grupo não só pela destreza com a escrita e o que vem com ela - afinal, posta-se como observador privilegiado -, como também pela inserção - ou possibilidade de inserção - por meio da edição de sua história, quando é alçado à categoria de autor).

Também reitera seu pertencimento a partir do estigma de "presidiário", que acompanha a recepção desses livros, mas também, como se viu, o seu próprio discurso. Não se trata, contudo, de discurso solidificado: há uma aposta num porvir não estigmatizado, embora, paradoxalmente, esses autores tenham que narrar a prisão, entendida aqui, de acordo com Myriam Castro, como "um lócus que, embora faça parte do contexto social global, está fora dele, não só pela sua circunscrição jurídica como pelas suas práticas específicas" ${ }^{25}$ - daí o que afirmei acima a respeito da costumeira fidelidade dessas narrativas às formas de sociabilidade do cárcere.

Lançando mão do livro (no que se destaca do que se espera do ambiente prisional), mas conformando-o às necessidades impostas por essa "microssociedade" (porque precisa honrá-la, sob risco de ser desleal aos companheiros), a recente literatura carcerária propõe uma identidade paralela à do presidiário, qual seja, a do escritor.

\section{IV.}

Antes de passar ao Capítulo 1, uma pequena citação, para que se esclareça o quão extraordinária é a situação abordada nesta tese: presidiários escrevendo histórias e conseguindo publicá-las em editoras de médio e grande porte.

\footnotetext{
${ }^{25}$ Myriam Castro, "Ciranda do medo: controle e dominação no cotidiano da prisão".
} 
Em seu Cabeça de porco, Luiz Eduardo Soares comenta o assassinato do traficante Márcio Amaro de Oliveira ("Marcinho VP"), em 2003, logo após o lançamento de sua biografia:

"[Márcio] temia ser assassinado não propriamente porque o livro [Abusado, de Caco Barcellos] divulgasse inconfidências que envolvessem terceiros, mas pelo simples fato de [ele] ser objeto de um livro, destacando-se, diferenciando-se, ultrapassando fronteiras simbólicas que o mundo cerrado da comunidade encarcerada erguia. Essas fronteiras invisíveis eram erguidas justamente para opor-se à diferenciação individualizante - sobretudo quando ela sugerisse possibilidades de mudança e de superação do universo valorativo compartilhado pelo universo dos apenados. Uma coisa é converter-se à Bíblia, que é parte do código cultural dos apenados, outra coisa é furar a parede cultural com livros, que são armas poderosas e perigosas porque absolutamente inclassificáveis. Pouco depois, em 2003, Márcio foi encontrado morto numa caçamba de lixo da penitenciária em que cumpria pena. Seus livros estavam jogados sobre ele, coroados por um cartaz: 'Nunca mais vai ler"',26.

${ }^{26}$ Celso Athayde, MV Bill e Luiz Eduardo Soares, Cabeça de porco, p. 107. 


\section{Capítulo 1 (ou "Cada detento, uma sentença")}

I.

Quando em 2001 Jocenir Prado publicou, pela Labortexto Editorial ${ }^{27}$, seu Diário de um detento: o livro, já tinha seu nome associado ao rap homônimo, do qual é co-autor, e que alçou o grupo de rap Racionais MCs ao que, com alguma licença, se poderia chamar de estrelato fora do "gueto"28. Daí, talvez, a necessidade de esclarecer, por meio do seu subtítulo (o livro), que aquele volume não trataria da música, conhecida no país pela voz de Mano Brown ${ }^{29}$.

A foto da capa, em preto-e-branco, é uma imagem do videoclipe da música "Diário de um detento", dirigido por Maurício Eça e Marcelo Corpanni, e mostra a silhueta de um homem com um cigarro em uma das mãos olhando, através das grades, para fora do presídio. Ainda na capa, a informação de que a apresentação é assinada por Drauzio Varella e que o livro é de autoria de Jocenir.

A própria identidade do autor do livro fica atrelada a sua relação com os Racionais, uma vez que adotou esse pseudônimo depois de Mano Brown ter confundido o seu verdadeiro nome (Josemir Prado), que nunca aparece, com "Jocenir". Com o sucesso da música, adotou como assinatura artística aquela que o notabilizara no rap feito em parceria com o famoso grupo da zona sul de São Paulo.

Ocupando as páginas 4 e 5, há uma fotografia de um homem de costas (parece ser Jocenir, embora não haja indicação que o confirme) em um salão, apoiado em janelas gradeadas. Outra vez, o olhar é para além das grades (aqui, o horizonte é bem mais restrito: avista-se outro prédio, no que parece ser o outro lado do pátio). Jocenir não aparece em fotografias ao longo do livro.

\footnotetext{
${ }^{27}$ A Labortexto, no início desta década, trouxe a público alguns livros escritos a partir da experiência do cárcere, como Sobrevivente André du Rap e Quatrocentos contra um: uma história do comando vermelho (2001), de William da Silva Lima, e também da assim autodenominada "Literatura Marginal", cujo exemplo mais destacado é o primeiro livro de Ferréz, Capão Pecado (2000).

${ }^{28}$ O CD Sobrevivendo no inferno (1997), no qual "Diário de um detento" consta como uma das faixas, vendeu cerca de 500 mil cópias. A associação entre periferia e gueto está presente nas letras do grupo. Ver, por exemplo: "Eu sou o Mano, homem duro do gueto, Brown Obá/ Aquele louco que não pode errar"; "Aí, você sai do gueto, mas o gueto nunca sai de você, morou, irmão?" ("Negro drama", do álbum Nada como um dia após o outro dia, 2002). Ou ainda: "O pobre, o preto, no gueto, é sempre assim/ O tempo não pára, a guerra não tem fim" (“Crime vai e vem”, idem, 2002).

${ }^{29}$ É, no entanto, o próprio Brown quem aparece, de costas, na capa do livro de Jocenir. Ainda que o líder dos Racionais só seja reconhecido pelo auxílio dos créditos dentro do livro.
} 
As fotos confirmam o que o título anuncia: é a história, o diário, de um detento.

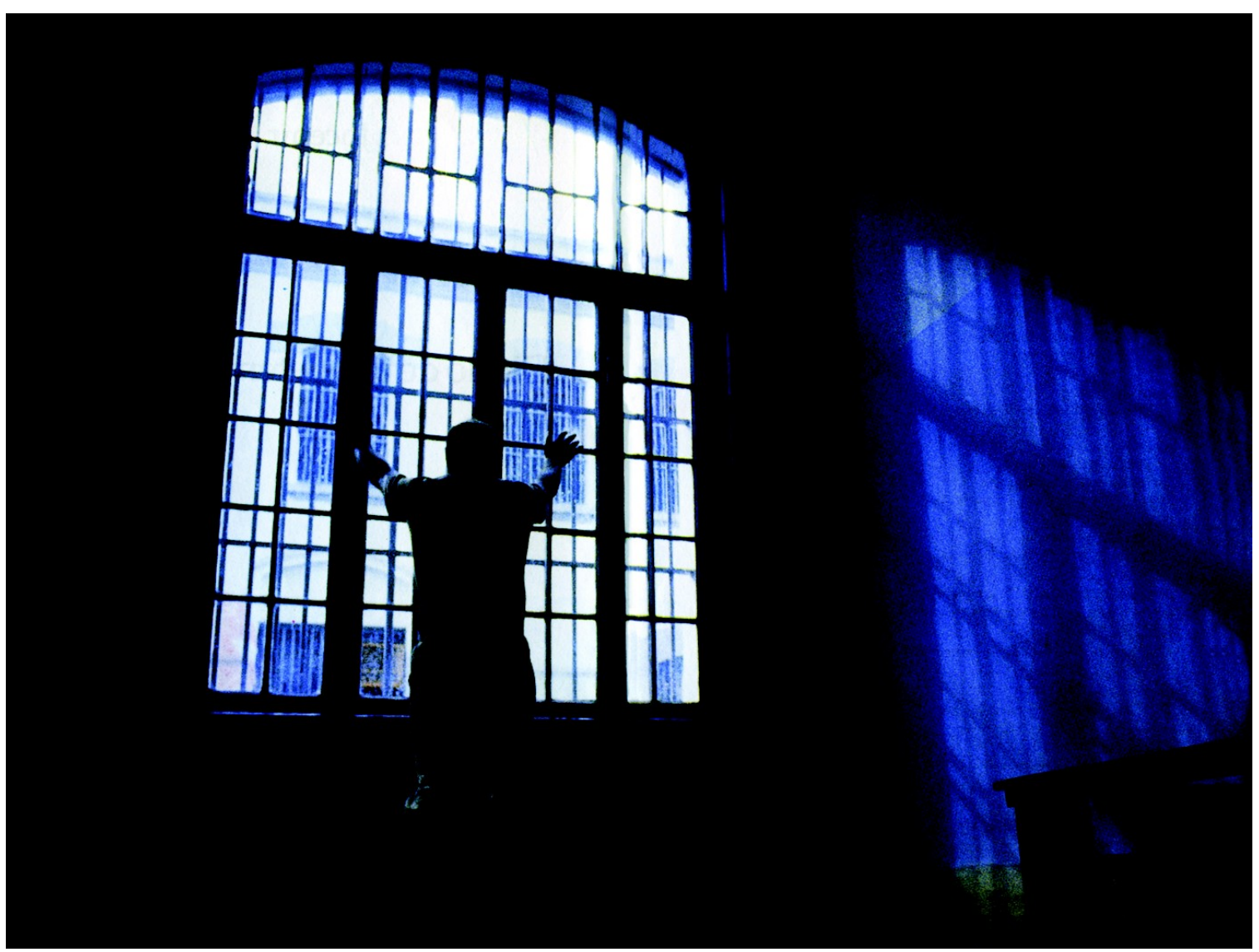

As histórias de prisioneiros se espalhavam, desde 1999, pelo país, muito provavelmente na esteira do enorme sucesso do best-seller de Drauzio Varella Estação Carandiru. O médico, aliás, além de responsável pela pequena apresentação do livro de Jocenir, tem um capítulo dedicado a ele, bem como é incluído na diminuta lista de agradecimentos que abre o volume.

Em comum, a música dos Racionais e o livro de Varella trazem o relato do massacre do Carandiru, em 1992, que Márcio Seligmann-Silva, em artigo recente, afirmou constituir “o núcleo e o ‘buraco negro’ em torno do qual esta nova literatura do cárcere se orienta" 30 .

Chamava-me atenção que o livro de Jocenir fosse composto não só pelos capítulos propriamente, ou seja, a "matéria narrativa" assim reconhecida, mas também por outras

\footnotetext{
${ }^{30}$ Márcio Seligmann-Silva, "Violência, encarceramento, (in)justiça: memórias de histórias reais das prisões paulistas".
} 
pequenas seções, cuja presença, se não chegava a destoar, era intrigante pelo que podia revelar.

O livro se estrutura da seguinte maneira:

Na seção dos agradecimentos, vêm citados apenas os nomes de (nesta ordem) Drauzio Varella; Ferréz; José Luis da Conceição, responsável pela foto que ocupa as duas páginas precedentes à de rosto; Mano Brown, responsável por aquilo que, na falta de termo mais apropriado, se pode chamar de sua "descoberta", e também "modelo" da foto da capa; Maurício Eça, diretor do videoclipe da música de Jocenir e Mano Brown.

Em seguida, a pequena apresentação de Drauzio Varella, em que o médico ressalta o fato de ser Diário de um detento "um livro escrito por quem experimentou a dureza do cárcere". Comenta ainda o estilo "cortante" de Jocenir e recomenda a leitura: "É um relato forte. Vale a pena ler". Percebe-se aqui a valorização, por parte do médico, da experiência na prisão, como a sinalizar que o autor daquele livro é digno de ser escutado ("relato") porque esteve presente, porque vivenciou uma situação-limite, a do cárcere. Esse aspecto não pode ser ignorado, não só porque está presente em boa parte das narrativas originárias do cárcere (de Dostoiévski a Graciliano), mas porque aparece expressa no livro em vários momentos - ou seja, a experiência é valorizada também por Jocenir e por seus companheiros.

Depois do sumário, a dedicatória aos cinco filhos, à cunhada e, em especial, à “companheira". Todos são nomeados e o serão novamente no último capítulo do livro, que narra o momento em que é libertado.

Os capítulos de maneira geral obedecem à cronologia dos fatos narrados: a prisão e a passagem por cadeias públicas e penitenciárias. Alguns deles são digressivos para que se possa narrar um episódio específico, nada que comprometa aquilo que o autor deseja que seja a compreensão exata, por parte do leitor, de como os fatos se deram. A preocupação com a fidelidade de suas palavras também se faz notar ao longo do livro e é aspecto importante para sua construção.

Além disso, um ponto central a Diário de um detento é o cuidado com a apresentação do espaço e do modo como a vida na cadeia funciona, em um reconhecimento ou expectativa de que aquele que o lê ignore o ambiente em que se desenrolarão as ações narradas, bem como as suas regras de convívio. 
As epígrafes que abrem alguns dos capítulos são extraídas do rap "Diário de um detento" e têm como tema o que de algum modo será tratado no capítulo seguinte, como se a letra da música reunisse os vários episódios por que Jocenir passou na prisão: uma espécie de mote à espera de glosa. O que me parece especialmente curioso aqui é que a história contada no rap de Mano Brown e Jocenir não é a história de Jocenir (não tem, portanto, apelo autobiográfico claro), que nem sequer estava preso à época do Massacre, mas a de outro(s) presidiário(s). Portanto, ao anteceder o relato de cada capítulo de sua história prisional - ou, como ele prefere chamar, de "seu inferno"31 - com um trecho da canção que não fala propriamente da sua vida, Jocenir compartilha o seu inferno, ou seja, a sua dolorosa passagem pelo sistema prisional paulista, com o de tantos outros "companheiros", como mostram alguns excertos do rap reproduzidos dentro dos capítulos: "Na cadeia, vale o que o sistema não quis, esconde o que a novela não diz" (p. 131)/ "Nada deixa o preso mais doente que o abandono dos parentes" (p. 116, p. 149 - na letra do rap, “preso” é substituído por "homem”).

Entre os capítulos "Um visitante chamado Mano Brown" e "Periferia, futebol e televisão", aparece fac-similada uma carta de Erick, um companheiro de cela, bem mais jovem que ele, a quem Jocenir aconselhava e por quem tinha se afeiçoado, apesar das constantes confusões em que o rapaz se metia. A carta vem depois de menção feita a ela no capítulo sobre Mano Brown, em que se lê: "Um ano após o encontro com Mano Brown, recebi uma carta de Erick dizendo que meus versos tinham se transformado em música, um rap, e que era um sucesso, tocava nas rádios a todo momento, tinham até gravado um videoclipe da música no Carandiru" (p. 101). Nesse sentido, a carta atestaria para o leitor a veracidade de seu sucesso.

\footnotetext{
${ }^{31}$ A imagem do "inferno" aparece nos outros livros dessa chamada "literatura dos cárceres", principalmente no de André du Rap (não por acaso, sobrevivente do Massacre - ver Capítulo 2), e faz lembrar os escritos de Primo Levi sobre o campo de extermínio (ver, por exemplo, É isto um homem?).
} 


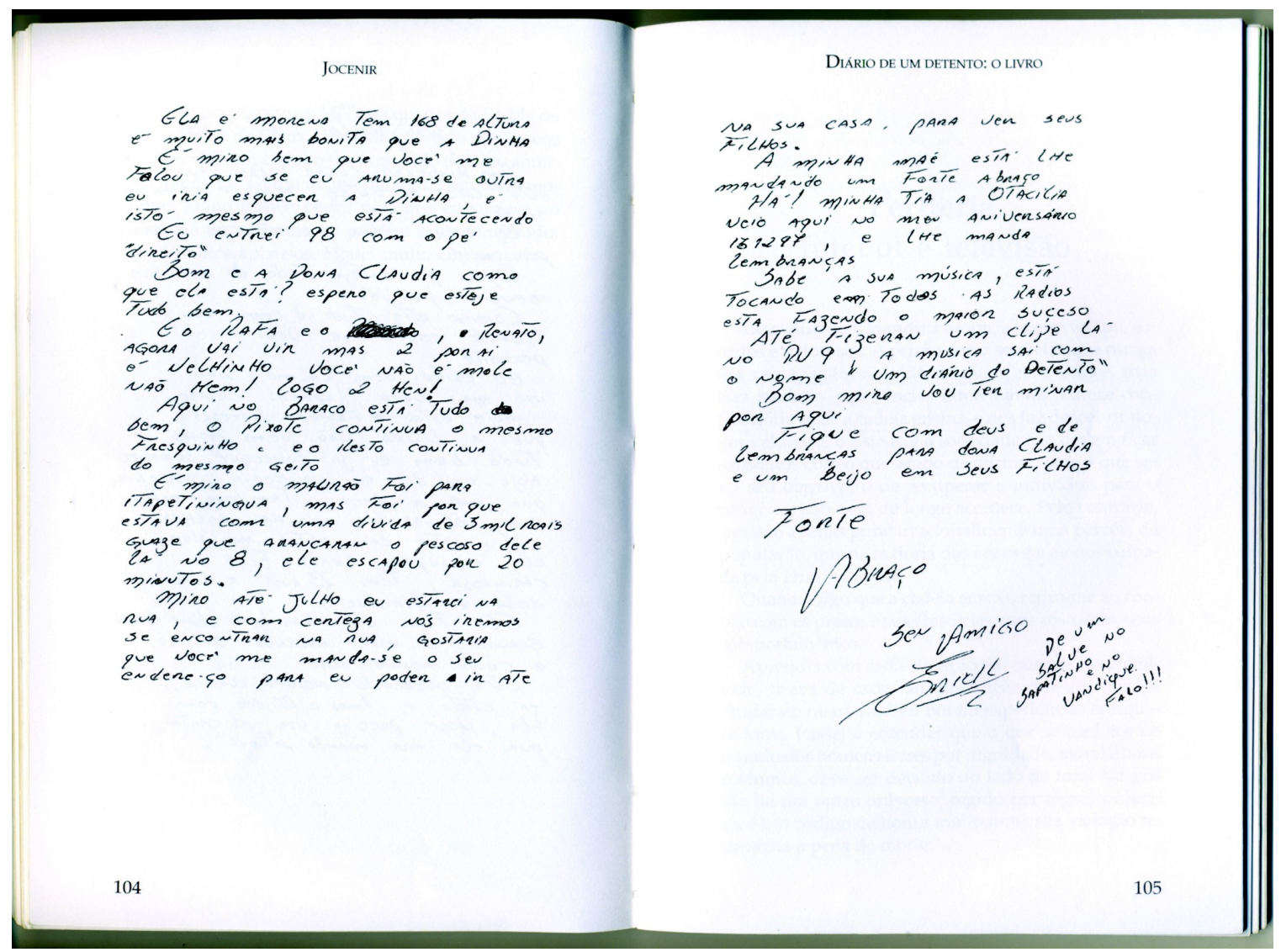

No fim do livro, "Um salve aos manos" (onze nomes, alguns seguidos de apelidos, aparecem): "A todos, mencionados ou não, minha mais profunda gratidão. Que Deus ilumine seus caminhos e alivie suas dores e sofrimentos" (p. 173).

Jocenir termina o livro com a transcrição da letra de "Diário de um detento", uma extensa narrativa que se passa entre a véspera e o dia seguinte ao Massacre do Carandiru, em outubro de 1992.

Essa disposição material parecia apontar para algumas particularidades do livro de Jocenir e em maior ou menor grau dos volumes que compõem o que se costuma chamar de "literatura carcerária": há uma conformação generosa do livro, visível no amplo espaço dedicado aos que o ajudaram na edição, aos que o esperaram pacientemente enquanto esteve preso e aos que esperam pacientemente presos. Parecia haver na maneira como se organizava o livro uma elaboração estética do etos, que supõe o companheirismo, a lealdade, a solidariedade, a humildade. 
Vista por outro ângulo, essa conformação não poderia estar só, uma vez que o livro como objeto não parece ser dos mais familiares aos presos - não entra, por exemplo, na ampla rede de trocas que alicerça a economia dos presídios, como cigarros, produtos de higiene pessoal, rádios, tvs, maconha, facas etc. Outras questões surgiam.

O livro de Jocenir estava sendo publicado por uma editora, que ao fazê-lo chancelava-o junto aos seus prováveis leitores; recebia de um médico, também autor de um grande best-seller sobre a prisão, um pequeno texto à guisa de prefácio recomendando a sua leitura. Para quem? Certamente, não para os detentos, para os quais os livros praticamente não chegam, para os quais, salvo raras exceções, o livro nem sequer é, como sugeri acima, um objeto familiar. O mais provável é que a publicação do livro e sua recomendação de leitura se dirigissem para aqueles que estão distantes do universo carcerário, o que, empregando expressão do próprio Jocenir, vou chamar de "mundo dos homens livres".

Sem negar nenhum dos ambientes - tanto aquele a que pertenceu enquanto esteve preso, quanto aquele a que deseja pertencer e do qual espera legitimação pela escrita -, Jocenir equilibra-se em um volume que é ambivalente na sua forma material, como também em sua forma narrativa.

Antes de partir para uma análise do texto propriamente, algumas considerações. Diário de um detento - como de resto a "literatura carcerária" ou literatura produzida a partir do cárcere - nasce sob o signo de uma ambivalência estrutural. E ela se deixa ver em pelo menos dois aspectos.

O primeiro deles diz respeito a uma movimentação do narrador que oscila entre a singularidade de sua experiência ("este é meu inferno, doloroso e meu”) e a necessidade um imperativo moral - de ampliá-la para a de um grupo ("Meu e de milhares de companheiros que tentam sobreviver trancafiados”, p. 17), coletivizando-a, sem anular as particularidades de cada sofrimento, de cada trajetória. Aqui, está-se diante de uma ambivalência circunscrita ao ambiente carcerário e, por isso, a chamarei de "interna".

Paralelamente, e eis o segundo aspecto, que não deixa de ser desdobramento do primeiro, há um movimento igualmente duplo de adesão aos códigos bem marcados de conduta do universo prisional e aos códigos de conduta entendidos como os do além- 
grades. ${ }^{32}$ Aderindo às normas de fora da prisão, o narrador singulariza-se dentro da prisão, mas também fora dela, uma vez que reconhece as "leis" que regem a sociedade e as toma para si, considerando-as legítimas e legitimadoras do seu discurso e da sua trajetória. Quando se aproxima das regras da prisão, o narrador autentica o discurso e a trajetória dos companheiros, bem como o seu na qualidade de "detento".

Essa dupla aderência aparece na construção sintática, que pode tanto remeter às estruturas orais, como a subordinações mais elaboradas, próprias do registro culto da língua.

Essa oscilação aparece também na eleição daquele para quem parece ser escrito o livro: em alguns momentos, Jocenir sugere voltar seu discurso para seus antigos companheiros de prisão, quando, por exemplo, dá lições aos mais jovens ou quando compartilha os valores ali dentro professados, mas em outros, mais imediatamente identificáveis, parece escrever para quem jamais esteve em um presídio ou em uma cadeia pública, daí a constante presença de expressões retificadoras: "O funcionário nos arrumaria os litros, mas exigiria um pau, isto é, uma taxa" (p. 120, grifos meus); "O mais agitado era Mineiro. Pálido, andava de um lado para o outro, dizia não querer justificativas, era da opinião de que deveriam subir o gás do Márcio, ou seja, matá-lo" (p. 133, grifos meus).

Essa preocupação de Jocenir em se fazer entender também por quem pertence a outra realidade ou é alheio às particularidades da vida no cárcere permeia o livro todo e surge na necessidade de clareza quase didática que imprime a seu texto. Veja-se, por exemplo, o esclarecimento trazido neste trecho que não faria sentido se unicamente dirigido aos companheiros de prisão: "Personalidades do meio artístico fazem com freqüência visitas à Detenção. Às vezes como contratados da direção do presídio para shows, às vezes para rever amigos cumprindo pena" (p. 99).

A coexistência desse movimento duplo do discurso que ora adere à perspectiva externa, ora à interna aponta para uma questão talvez anterior, qual seja, a própria escolha do livro como meio privilegiado de expressão. Parece-me que a adoção do livro não

\footnotetext{
${ }^{32}$ Um esclarecimento talvez seja necessário: quando estabeleço essa distinção entre códigos de conduta dos presos e dos homens livres, eu o faço em função do que mostram os próprios relatos prisionais: na cadeia, o modo pelo qual os detentos pautam seu comportamento é fruto de uma rígida normatização elaborada por eles mesmos e que não corresponde exatamente ao que se supõe dos homens do além-grades. Isso deve ficar mais claro adiante.
} 
significa aceitar suas "limitações", seu estatuto previamente dado e que não corresponde ao etos prisional, o que se percebe na própria estruturação das partes que o compõem. Quero sugerir que o livro assume em Diário de um detento como em outros exemplares dessa "nova literatura do cárcere" um formato próprio, que, por sua vez, é revelador de um "conjunto de traços" que faz com que esse narrador, sem perder sua especificidade óbvia, pertença a um grupo. Ao escolher o livro, objeto raro nas prisões da pouco letrada sociedade brasileira, Jocenir o faz de modo a não recusar sua condição dolorosa de encarcerado, o que significa inserir-se em uma coletividade e tomar para si muitos de seus valores. Isso aparece na estruturação do volume, mas também no próprio texto, e de maneira tão coesa que é possível arriscar que tudo - não só os capítulos, mas as seções de abertura e de fechamento do volume - componha a matéria narrativa de Diário de um detento.

Está-se diante, portanto, de um volume cuja estrutura, exigida pela tensão presente da vida no cárcere, configura-se como peculiar. Procurarei a seguir mostrar como esse movimento ambivalente aparece em Diário de um detento e quais os desdobramentos surgidos daí.

II.

A apresentação do espaço no qual se desenrolam as ações narradas merece atenção especial na "literatura carcerária". Se tomasse de empréstimo as palavras de Lukács em seu célebre ensaio "Narrar ou descrever?", diria que em Diário de um detento "a narração distingue e ordena" (em oposição à descrição, que, segundo o mesmo autor, "nivela todas as $\operatorname{coisas}{ }^{33}$ ), uma vez que o espaço é fundamental nessas narrativas. O espaço narrado confina, enclausura, animaliza, se torna metáfora da condição encarcerada ("as grades"), remodela as relações de tal modo que aparece até na capa do livro.

Há, portanto, uma preocupação bastante expressiva em situar o leitor quanto ao ambiente narrado e suas implicações. De modo geral, a apresentação do espaço vem antes do entrecho e surge acompanhada de observações sobre as condições precárias das cadeias e presídios. Observe-se o quarto parágrafo do livro de Jocenir:

\footnotetext{
${ }^{33}$ Georg Lukács, Ensaios sobre literatura, p. 62.
} 
“A privação da liberdade, retirar o condenado do convívio social, não representa o maior sofrimento do homem que passa a fazer parte da realidade carcerária do país. A hipocrisia da elite, bem como das instituições públicas, não admite que esta idéia seja propagada: os distritos policiais, cadeias públicas e alguns presídios, antes de restringir a liberdade de um indivíduo, tirá-lo de circulação, são campos de concentração, senão piores, iguais aos que os nazistas usaram para massacrar os judeus na $2^{\text {a }}$ Guerra Mundial. São verdadeiros depósitos de seres humanos tratados como animais" (pp. 17-18).

A denúncia do sistema penitenciário faz-se presente ao longo desse livro. Na ausência de parâmetros que dêem conta do horror vivido, apela-se à comparação - também presente em outros volumes sobre o cárcere - com o Holocausto, em uma tentativa de inscrever-se em um sofrimento reconhecido como tal por quem o lê.

As instalações, o relato da violência entre os presos (como parte da práxis local), a higiene, a comida, as drogas - tudo compõe um cenário assustador que serve a um só tempo para tentar sensibilizar os "de fora", sem faltar com a lealdade aos "de dentro", que sofrem com os desmandos do "sistema"34.

\section{III.}

Logo no início do livro, Jocenir comenta:

“Tudo o que se possa julgar sobre uma prisão não pode ser fundamentado nos princípios morais, éticos e religiosos da sociedade dos homens livres. Nela os princípios são outros, escritos pelo sofrimento e pela delinqüência do mundo marginal” (p. 19, grifos meus).

\footnotetext{
${ }^{34} \mathrm{O}$ uso do termo "sistema" merece atenção. Pode referir-se tanto ao sistema penitenciário, como a genericamente tudo aquilo que oprime o preso: a estrutura sócio-econômica, a elite etc.: "É duro ser bode expiatório do sistema. Fiquei pensando naquele momento qual seria o tamanho do presídio se a justiça funcionasse e botasse todos os criminosos de colarinho branco. Eles teriam direito a corredor polonês? Comeriam merda?" (Diário de um detento, p. 80), ou então: "Os presos são vitimados por transgressões de todas as ordens. O sistema não educa. Pune de maneira cruel, machuca o homem para sempre, o torna quase irrecuperável" (idem, pp. 53-54). O "sistema" pode ser ainda, embora mais raramente, algo que os aglutine e cujas regras devam respeitar.
} 
Evidenciam-se no excerto acima alguns aspectos relevantes para a escrita desse autor, que diferencia, por oposição, a "sociedade dos homens livres" da prisão, baseando a distinção nos códigos de conduta, que são também princípios morais, e nos valores vigentes na cadeia.

Hoje talvez de conhecimento mais amplo - até mesmo em função do crescente interesse pelo assunto -, a existência de um rígido conjunto de normas entre os presos poderia ser motivo de espanto. O percurso do prisioneiro supõe, quando "homem livre", a infração às leis e - como sabê-lo? - o não reconhecimento de sua legitimidade. Uma vez preso, há de se submeter (o que implica aprendizado mais ou menos rápido) às leis da prisão: as do presídio como instituição, mas principalmente as geridas pelos próprios prisioneiros (e das quais a instituição presídio também se beneficia).

Muitos dos comportamentos esperados são aqueles que valem para os "verdadeiros malandros" ainda antes de serem presos: como a não delação, a cobrança da palavra empenhada. Outros são mais propriamente aplicados ao ambiente prisional, porque decorrentes das circunstâncias (como o respeito às visitas: "O respeito é fundamental. Qualquer visita é bem recebida. No código de honra dos presos, maltratar uma visita pode levar à morte", conta Jocenir, à página 96) e, a bem da verdade, não chegam a causar espanto: em situação de extrema precariedade material, esses homens se organizam para estabelecer um convívio possível.

O tribunal não é moroso, o julgamento é rápido, e a pena, amiúde, capital. A lei vigente é a de que alguns, por infringirem o código local, não seriam dignos de viver entre eles: "Procurava conhecer bem as normas do presídio a fim de não as transgredir. Prestava muita atenção às normas de conduta dos detentos. São eles que determinam a vida cotidiana no Carandiru" (p. 85).

Para o bom funcionamento da cadeia, alguns valores como respeito e honra precisam ser preservados: "Em jogos entre times na detenção não existem palavrões nem ofensas. Tudo transcorre no maior respeito e harmonia, assim evitam-se problemas e brigas sérias. A honra de um preso vale muito" (p. 109, grifos meus).

Repare-se aqui na necessidade de dar a perceber ao leitor (que, a julgar pelo que sugere o texto, é alguém que desconheceria aquele ambiente) a importância, inclusive para os episódios narrados no livro, da adesão do preso àquele código. E sentencia: não se pode 
olhar para a prisão com os mesmo parâmetros que se enxerga o "mundo dos homens livres" - a situação é outra, exige conformações próprias. ${ }^{35}$

$\mathrm{O}$ etos prisional liga-se primordialmente à palavra empenhada. É ela que determina a existência de respeito e honra por parte dos presos: "Uma palavra mal colocada, um desentendimento, seria motivo para começar uma carnificina" (p. 137). Mas liga-se também, para além das obrigações, ao senso de fratria ${ }^{36}$ e solidariedade. O reconhecimento por parte dos presos de que partilham infortúnios traduz-se em ações de companheirismo. Aqui, Jocenir conta como foi amparado pelos outros detentos depois de ter sido surrado pelos carcereiros na Cadeia Pública de Osasco:

"Imediatamente procuraram me ajudar, perceberam o péssimo estado em que me encontrava depois das duras agressões que sofri. Pediram a alguns manos que esquentassem água para que eu pudesse mergulhar meus pés, que estavam inchados demais (...) Um dos presos gentilmente ofereceu-me a cama em que dormia, a fim de que eu ficasse melhor acomodado e descansasse" (pp. 59-60).

A cena se repetiria. Logo na chegada ao Carandiru, depois de ter sido torturado na Cadeia Pública de Barueri, ele conta que: "Das celas, os presos gritavam oferecendo algum tipo de ajuda, roupa, alimentos, remédios (...) A todo momento apareciam presos procurando saber de onde vínhamos, nos traziam mais alimentos e roupas limpas" (p. 81).

Por parte dos presos, há, evidentemente - e a existência do código de conduta implacável é prova disto -, a percepção de que, mobilizando-se coletivamente, têm mais chances de se preservar. No caso de Jocenir, a popularidade de que goza por ser "homem das letras" (discutirei mais detidamente essa dimensão no item IV), por escrever cartas ${ }^{37}$

\footnotetext{
${ }^{35}$ Observe-se, por exemplo, este episódio, narrado no capítulo "A chegada de Márcio": Márcio, seu irmão, chegou à Casa de detenção sob ameaça de outros presos que, supostamente, haviam sido roubados "lá fora" por ele. Em episódio delicado como esse, Jocenir revela que o etos prisional supõe, em muitos casos, a conversa, o debate. Quando explica a situação aos companheiros de cela, recebe apoio ("Disseram estar dispostos a me ajudar, iriam propor um debate para clarear a situação", p. 136), mas também um alerta: caso se confirmasse o erro do irmão, valeriam as regras do cárcere ("Fui avisado: se meu irmão estivesse errado, seria a cara dele procurar uma forma de acertar com os manos, me disse Branco, de forma incisiva", p. 136).

${ }^{36}$ Maria Rita Kehl explorou em um ensaio intitulado "A fratria órfã" a importância do sentido de fratria no discurso do rap, que não por acaso é incorporado pelos próprios prisioneiros.

${ }^{37}$ As cartas ocupavam, a julgar pelo que nos contam os livros produzidos a partir do cárcere, enorme espaço na rotina prisional. É por meio delas que se dá a comunicação com o mundo exterior, sobretudo
} 
para as famílias dos outros presos, contribui claramente para o respeito solidário que muitos lhe dispensam. Em momento embaraçoso em sua passagem pela prisão, ele narra que:

\begin{abstract}
"Reuni meus companheiros de cela para colocá-los a par do que estava para acontecer, rapidamente prestaram solidariedade a mim, estavam do meu lado para o que desse e viesse (...). Muitos manos queriam falar comigo sobre o assunto, aos poucos eu ia recebendo o apoio de muitos lugares do presídio. Dos pavilhões chegavam mensagens de força, eu era sangue-bom, e muito respeitado na Casa de Detenção de São Paulo" (p. 135).
\end{abstract}

Note-se, aqui, a aderência ao etos prisional, revelada na nomeação dos pares como “companheiros" e "manos". Ele reconhece naqueles que o amparavam um comportamento digno e correto, por ser o narrador igualmente digno e correto ("sangue-bom"). Desperta interesse a estruturação do trecho, em que o narrador parece proceder de duas maneiras, alternando um registro coloquial (como a reproduzir a provável fala de alguém: "estavam do meu lado para o que desse e viesse", "eu era sangue-bom") e o seu correlato em chave culta ("prestaram solidariedade a mim”, "[eu era] muito respeitado na Casa de Detenção de São Paulo" - respectivamente). O que não significa, importante frisá-lo, o abandono da percepção de que escreve para quem não compartilha esse etos - tanto que, ao lançar mão dos dois registros, emprega uma sintaxe culta, própria ao registro escrito.

O elogio do espírito fraterno no cárcere aparece de modo eloqüente no momento em que narra a chegada do seu "alvará de soltura". Trata-se do último capítulo do livro, não por acaso chamado "Adeus sangue-bom". Aqueles que ficavam eram os que davam adeus. Nesse sentido, no título, Jocenir presta homenagem, transferindo o foco narrativo aos companheiros cuja hora de saída ainda não tinha chegado. A estrutura do capítulo contribui para essa sensação de que era preciso, mais uma vez, dar espaço a outros relatos que não apenas o seu. No momento mais desejado, Jocenir, em pequena digressão, interrompe a narrativa de sua saída da prisão para comentar a importância de sua amizade com outro detento, Papi. Apesar de tão aguardado por ele, o momento de liberdade era também o de

quando os presos estão recolhidos em unidades distantes das suas cidades de origem. 
reverenciar os "aliados", em clara expressão dos valores da cadeia. Claro, não era qualquer aliado, mas Papi, com quem, nos últimos meses, havia passado madrugadas em longas conversas.

Nesse capítulo, que, aliás, precede a seção "Um salve aos manos" (aquela na qual faz questão de nomeá-los em movimento de explicitação dos laços de afeto), lê-se:

"Ia pela galeria com um funcionário de cada lado quando comecei a ouvir de dentro das celas os gritos de adeus e boa sorte. Eram muitos gritando ao mesmo tempo. Em determinado momento o som tornou-se ensurdecedor, os companheiros começavam a bater com suas canecas de plástico nas portas. Era uma homenagem. Fiquei emocionado. (...) Ao olhar para as celas, os manos paravam de bater suas canecas e com as mãos me desejavam felicidade e boa sorte. Seguia pela galeria e meus olhos se enchiam quando das portas partiam os sinais de positivo e vitória das mãos dos que ficavam" (p. 170).

O emprego de "olhos se enchiam" pode ser interpretado como uma junção das expressões "olhos cheios d'água" e "de encher os olhos" (aqui, como sinônimo de contentamento). $\mathrm{O}$ uso do clichê, dada a lacuna que pode ou não ser preenchida por "d'água" (afinal, os olhos apenas se enchem, não se sabe de quê), não é completo, e o enunciado se oferece em chave dupla, tensionando algo cujo sentido seria dado de antemão, se apenas clichê fosse. Nesse flerte que não se completa com o fácil, com o lugarcomum, o texto de Jocenir se revela em sua ambivalência de registros.

A incorporação dos valores da prisão, sem que isso representasse a recusa daqueles compreendidos como próprios ao mundo dos homens livres, aparece assim formulada na escrita de Diário de um detento:

"Quando digo que a cadeia ensina, refiro-me ao contato com os presos e suas histórias, seus costumes, seu comportamento. (...) Aprendia com cada situação em que me via envolvido, tirava de cada fato uma lição que aos poucos mudava meus valores. Foram experiências enriquecedoras. Passei a entender que o que se conhece no mundo dos 
homens livres por dignidade, moral e bons costumes, deve ser deixado do lado de fora. Na prisão há um outro universo, regido por regras próprias, e um código de honra muito forte, sua violação representa a pena de morte" (p. 107).

Jocenir faz questão de explicar ("quando digo que..., refiro-me a"), para que não pairem dúvidas quanto à ineficácia do desumano sistema penitenciário. O aprendizado vem, não da instituição, mas da troca de experiências entre homens ${ }^{38}$ que, reduzidos a um espaço exíguo, alçam a palavra a um estatuto sem igual se se considerar o lado de fora da prisão. É a esse público de fora da prisão que, na maior parte das vezes, Jocenir se dirige e a quem precisa dar explicações. Sendo os seus prováveis leitores associados ao "sistema", haveria o risco, que Jocenir não quer correr até mesmo em lealdade aos companheiros, de se acreditar que, em última instância, a cadeia pudesse educar.

Não há espaço para essa dúvida:

"Meus dias no Carandiru foram, a um só tempo, sofridos e valorosos. A prisão deixa seqüelas que nunca mais se apagam na vida de quem nela esteve, mas traz também experiências interessantes. Parece contraditório, mas a cadeia ensina, e nos faz descobrir novos valores. E o Estado e a sociedade não devem ficar satisfeitos com o que acabo de afirmar, pois o que seria seu objetivo, o de recuperar o indivíduo para o convívio, isso nem de longe acontece. Pelo contrário, a prisão apenas pune irracionalmente uma parcela da população, que na maioria das vezes é a menos culpada pela criminalidade” (p. 107).

O reconhecimento de uma identidade prisional contribui para essa clara distinção que estabelece entre os códigos de conduta e seus desdobrados registros lingüísticos. Pense-se, por exemplo, na maneira como apresenta Papi, "um argentino de 74 anos que cumpria pena por tráfico de droga" (p. 167). Além da idade e nacionalidade (dados, aliás, nada desprezíveis, porque podem despertar a compaixão: trata-se de um homem idoso e estrangeiro), o que se sabe sobre esse personagem é apenas a razão de sua pena, em clara

\footnotetext{
${ }^{38}$ Veja o que diz sobre as conversas com o argentino Papi: "Nas longas noites que passamos conversando, pude ouvi-lo narrar situações e acontecimentos que com certeza dariam um excelente livro" (p. 162).
} 
incorporação do discurso institucional em imagem ${ }^{39}$ feita do amigo. Naquele ambiente, o crime cometido passa a determinar a identidade. ${ }^{40}$

Importa pensar que a explicitação da existência de rígido código de conduta, bem como de valores comungados coletivamente, expõe igualmente a existência de uma forma narrativa e material que procura dar conta deles. Tomado por esse etos, o escritor precisa conformar a sua escrita a esse modo de ver o mundo, sob o risco de ser desleal (lembre-se: a lealdade é um valor) por não "narrar a verdade da cadeia". Entre o etos da cadeia e a expectativa de ser alçado a escritor (pertencer, portanto, ao mundo dos homens livres), há um abismo social e, claro, narrativo - e é onde reside a especificidade da prosa prisional.

IV.

Jocenir, como outros dos autores discutidos neste trabalho, trata a escrita como um “dom”, ou seja, como algo que lhe foi dado, sem que para isso despendesse maior esforço. Nesse sentido, sente-se em dívida com aqueles que não foram merecedores da mesma sorte e dispõe-se a narrar também em seu lugar. ${ }^{41}$

O estatuto obtido graças à familiaridade, que pode ser mínima, com a prática da escrita e da leitura é em si denunciadora da realidade sócio-educacional brasileira. Interessa-me pensar mais detidamente em como essa percepção do dom transforma-se em um certo senso de missão que se manifesta na necessidade premente de narrar a experiência - e isso é um traço constitutivo da chamada literatura de testemunho, mas que aqui ganha dramaticidade social em função do letramento extremamente baixo dos presidiários -, sem deturpá-la. Como sentencia logo no início do livro: "Quero pintar um quadro que possa dar uma idéia do que se passa no interior de uma prisão brasileira, um quadro macabro, mas também repleto de histórias humanas" (p. 17).

Com isso, devolve-se o que ganhou, respeitando dois preceitos fundamentais: a lealdade ao realmente vivido (reiteradas vezes manifesta) e, como um desdobramento, o respeito aos "companheiros de sofrimento".

\footnotetext{
${ }^{39}$ Ver, a esse respeito, o volume organizado por Ruth Amossy, Imagens de si no discurso.

${ }^{40}$ Apropriar-se do discurso oficial, institucional a respeito dos companheiros presos é um recurso de que se vale também Humberto Rodrigues (ver Capítulo 4).

${ }^{41}$ É possível pensar também que, nesse sentido, é um herdeiro da tradição da autobiografia moderna, que, como afirma Mario Barenghi, "desenvolveu-se sob o signo da tensão entre exemplaridade e excepcionalidade” (Mario Barenghi, “A memória da ofensa: recordar, narrar, compreender”, p. 177).
} 
No capítulo "A rebelião", conta que, depois de ter sido surrado e humilhado por policiais, havia rezado e agradecido a Deus por tê-lo "preservado do pior" e que havia prometido publicar - um dia - a prece feita naquele momento. A publicação da oração ao final desse mesmo capítulo é um acerto de contas consigo e com sua fé. ${ }^{42}$

Há, aqui também, um movimento ambivalente - o dom é singular e pessoal, mas a devolução deve ser mais ampla, coletiva portanto. A sua história é parecida com a de outros. Ao narrá-la, Jocenir individualiza-se, mas o faz também em nome daqueles que não têm o privilégio da escrita.

Atente-se para o fato de que é preciso narrar pelos companheiros, mas não exatamente para os companheiros. O público visado, como já mencionei, é aquele que desconhece $\mathrm{o}$ ambiente prisional, assim como aquele que flerta com a marginalidade e deve tomar aquelas palavras como sábios conselhos. Se é Jocenir quem assina o livro - e nesse sentido, ao ressaltar sua inserção na categoria de autor, singulariza-se -, os valores e os sofrimentos são partilhados pelos outros encarcerados, que se reconhecem naquela história - coletivizando-a.

A relação com a escrita ocupa lugar fundamental em Diário de um detento e pode ser vista, inicialmente, sob três ângulos assim formulados por seu narrador: evitar aborrecimentos com outros presos; fazer o tempo passar; adquirir status em função da destreza com as palavras. São três possibilidades conferidas à leitura e, sobretudo, à escrita dentro do cárcere.

Em primeiro lugar, argumenta que essa atividade o resguardava das confusões:
"A maior parte do tempo eu procurava ficar dentro da cela escrevendo versos e cartas, ou lendo livros espíritas. Desta maneira evitava contato direto com alguns elementos indesejáveis. Também não ficava exposto a acontecimentos violentos que ocorriam com freqüência" (p. 45).

\footnotetext{
${ }^{42}$ É também, na aguda observação de Márcio Seligmann-Silva, a única instância de quem se espera justiça: "Se universo jurídico e Justiça não têm nada em comum a não ser a sua mútua exclusão, esta literatura [dos cárceres] é uma das provas mais contundentes deste fato. Não por acaso Hosmany Ramos vai fazer apelo à 'Justiça divina' ao descrever o massacre do Carandiru (...). Esta parece ser a única justiça possível em um mundo carcerário abandonado ao tempo da repetição infernal do castigo" ("Violência, encarceramento, (in)justiça", op. cit., p. 7).
} 
Em segundo lugar, porque a escrita e a leitura contribuíam para diminuir a angústia do tempo que custava a passar:

"Eu procurava vencer o tempo. Na cadeia o tempo anda em câmera $\underline{\text { lenta }^{43}}$. Fazia versos para os presos presentearem suas famílias, também lia e respondia cartas. Com isto, ia pouco a pouco ganhando a simpatia de todos, até dos mais perigosos. Por ler e escrever com facilidade, o que é raro na cadeia, tomei contato com muitas almas infelizes. Isso era bom, ganhava respeito, mas virei espectador de muitas tragédias" (p. 55 , grifos meus).

No trecho acima, o que se percebe também - e este é o terceiro ângulo pelo qual se pode analisar a sua relação com a escrita - é que a declarada destreza com as palavras lhe rende fama e respeito. Além disso, chama atenção que Jocenir assim a perceba, mais uma vez reforçando a sua posição singular no ambiente carcerário, salientada ainda mais quando se leva em consideração que ele se opõe às "almas infelizes", que, no entanto, encontravam-se na mesma condição que ele. ${ }^{44}$

"Prova"45 dessa condição de "homem das letras" é que, como ele nos conta, os seus cadernos repletos de versos circulavam pelos pavilhões para serem copiados pelos detentos, que se reconheciam naqueles versos, sem, no entanto, deixar de enxergar em Jocenir uma posição destacada em função do trato com as palavras ${ }^{46}$.

Se se ampliar a questão, será possível ver a relação com a escrita, em um desdobramento da abordagem inicial com seus três ângulos (quais sejam: evitar aborrecimentos; passar o tempo; adquirir status), sob dois aspectos. Em primeiro lugar: a

\footnotetext{
${ }^{43}$ A frase em destaque é também parte da letra do rap "Diário de um detento", o que contribui para a sugestão de que haja aí o tal movimento de singularização, presente na adoção do "eu" para contar o seu empenho em minorar o tempo ocioso, e expansão, visível na incorporação desse rap, que, em sua expectativa de representatividade, pode ser visto como a história de todo detento.

${ }^{44}$ Humberto Rodrigues adotará procedimento que caminha na mesma direção.

${ }^{45}$ As aspas em "prova" devem sinalizar aqui a necessidade instante de atestar a veracidade do que é dito pelo autor, que, a todo tempo, exemplifica o que conta com acontecimentos. Essa idéia de "prova" remete, evidentemente, a uma situação de tribunal - de algum modo, repõe-se a todo tempo a cena do julgamento. Márcio Seligmann-Silva discutiu essa dimensão em seu "Violência, encarceramento e (in)justiça": "A literatura dos cárceres coloca-se abertamente enquanto literatura-denúncia, cumprindo o papel de acusação nos tribunais jurídico e da história" (p. 5).

${ }^{46}$ Segundo Jocenir, a popularidade de seus versos levou-o a ser apresentado a Mano Brown, o líder dos Racionais. Esse encontro rendeu a já referida parceria famosa.
} 
facilidade com a escrita, ao mesmo tempo em que cria uma identidade prisional (a de alguém que sabe escrever bem, sabe fazer versos, mas que continua detido), destaca-o do conjunto de detentos, singularizando-o, aproximando-o da função almejada de escritor.

Justamente esse movimento, decorrente da facilidade com as palavras, capaz de alçá-lo à categoria de autor na ocasião da publicação do livro, constitui o segundo aspecto pelo qual se pode discutir a relação de Jocenir com a escrita. Trata-se da possibilidade de recuperação.

"A dor de cada um se transferia para mim, e de mim para o papel. Primeiro ouvia atentamente o que o companheiro dizia, procurava interpretar suas ansiedades, seus sonhos, seus desejos. Se o solicitante quisesse versos para a esposa, eu procurava compor como se fosse para minha esposa, para algum amigo, procurava pensar em algum amigo, filhos, pensava nos meus, e assim sucessivamente. Incorporava nos versos minhas experiências que, sabia, eram as mesmas daqueles homens. $\underline{\text { Cada detento uma mãe, uma crença, cada crime uma sentença, }}$ cada sentença um motivo, uma história de lágrimas, sangue, vidas inglórias, abandono, miséria, ódio, sofrimento, desprezo, desilusão, ação do tempo. Traduzia o cárcere com um lápis” (p. 97, grifos meus).

O movimento que pode ser lido em chave dupla aparece explicitamente quando Jocenir afirma que as experiências eram as mesmas (e, nesse caso, ele sendo um "homem de letras" é capaz de traduzi-las para o papel, o que o singulariza nesse conjunto), mas também quando lança mão de um trecho de sua música famosa (em destaque na citação) para sinalizar que há uma experiência comum em jogo e que seu livro é o relato de "seu inferno", que, por sua vez, é muito próximo ao de tantos outros. Repare-se em que, depois de assumir que as experiências eram próximas, recorre ao trecho da canção que aponta para a singularização. Esse vai-e-vem costura a narrativa de Diário de um detento.

A desenvoltura com as palavras the rende, então, para além da fama de homem das letras, um ofício - raro na cadeia e reconhecido como digno também fora dela. Assim, a segunda abordagem, com seus dois aspectos (quais sejam, o tornar-se escritor e o vislumbre de uma recuperação por meio desse novo estatuto), aponta para fora do cárcere. 
V.

No capítulo em que narra a chegada à Cadeia Pública de Barueri, logo no início de sua detenção, comenta a respeito dos presos que já estavam por lá:

"Vieram para me ver. Faziam inúmeras perguntas ao mesmo tempo, todos juntos, querendo a minha atenção. Alguns pediam os meus sapatos, outros a minha roupa. Eu estava atordoado com o que via e ouvia. Uma multidão de pobres-diabos molambentos me chamando. Meus companheiros” (p. 41).

Aqui, a parataxe acentua a percepção que Jocenir tem do quadro miserável que o cercava e do qual ele começava a fazer parte, sem, ainda, atribuir-lhe relações de sentido. Acentua seu mal-estar, por não se sentir parte do ambiente, mas dá-se conta de que já pertencia àquele lugar e tinha, portanto, aqueles "pobres-diabos molambentos" como "companheiros". O termo não poderia ser mais justo. Companheiro é aquele que, nas acepções dicionarizadas, "participa das ocupações, atividades, aventuras ou do destino de outra pessoa" ou "aquele que vela por uma pessoa, trazendo-lhe consolo ou ajuda". É isso que Jocenir percebe durante todo o tempo de encarceramento.

O desconhecimento do rap é também um modo de singularizar-se em meio à massa carcerária (aqui, pela idade e pela origem), embora se perceba o respeito ao tratar do assunto: “(...) sabia da admiração e do respeito que os presos cultivavam pelo rap, em especial os mais jovens. Sempre ouvia falar do som dos Racionais MC's, e sabia da identificação daquela gente sofrida e condenada com Mano Brown. Eram da mesma realidade" (pp. 99-100).

Nesse trecho, quando se refere aos "presos", exclui-se do grupo, assim como quando se refere a eles como "gente sofrida e condenada". Aproxima-os de Brown - mas não de si -, ampliando a distância estabelecida.

Ao longo de sua narrativa, Jocenir vai se familiarizando com as demonstrações de lealdade, companheirismo, solidariedade, imbuído que estava dos chamados "valores da prisão". O momento em que isso atinge o paroxismo é precisamente quando, na cadeia de Avaré (no interior de São Paulo), recebe uma carta de Tadeu, um de seus antigos 
companheiros de cela no Carandiru, avisando que "chegara ao presídio Adrenalina", um preso que o havia agredido impiedosamente na Cadeia Pública de Barueri, porque Jocenir se negara à extorsão, prática veementemente condenada nos presídios. Assim é narrado o episódio:

"[ a carta de Tadeu $]$ dizia que muitos detentos que presenciaram a covardia de Adrenalina e seus comparsas em Barueri queriam, em respeito a mim, subir com o referido elemento. E mais, queriam que a decisão partisse de mim. Sim ou não, matar ou não Adrenalina? Por um lado, me emocionei com tamanho respeito e consideração que os manos daquele presídio tinham com minha pessoa. Por outro, fiquei chocado com a possibilidade de decidir de maneira tão banal a vida de um ser humano" (p. 144).

Note-se que aqui, para explicar o termo "subir", não faz uso de expressão retificadora (até porque o termo já havia sido esclarecido páginas antes, no episódio envolvendo seu irmão), mas de sinonímia algumas linhas depois (“matar"). Não deixa de aderir à ótica prisional quando não se preocupa em dar imediatamente o significado do termo, mas, quando lança mão de um sinônimo, parece ter em perspectiva a possibilidade de ser lido pelos que estão fora da cadeia. Ademais, a aderência ao código local divide espaço com os valores dos homens livres, segundo os quais não vale - ou não deveria valer - a lei de Talião.

Essa incorporação dos princípios norteadores da conduta prisional é decisiva na construção narrativa do livro. Percebe-se isso, por exemplo, quando escreve sobre o amigo Tadeu e faz questão de expressar sua gratidão e lealdade:

"Desde que chegou à Casa de Detenção, Tadeu foi uma companhia constante. (...). Devo-lhe muito pelo amigo leal que sempre foi. Deus queira me permitir algum dia retribuir tudo o que ele fez por mim (...) Aprendi a admirá-lo pelo caráter, pela simplicidade e humildade. (...) Todos que o conheceram passaram a respeitá-lo como pessoa de bem e sujeito homem, pois tinha muita palavra e honra" (p. 124). 
O que se nota aqui é a assimilação do modus operandi prisional, com a valorização da humildade - sempre exaltada como uma das qualidades mais importantes em um preso -, da lealdade, da solidariedade, do companheirismo. Além disso, paira a necessidade de retribuir algo que the foi dado ${ }^{47}$. A idéia de "aprendizagem" revela um antes e um depois na trajetória narrada. A conseqüente ampliação dos que, como ele, consideram Tadeu dono de muitas qualidades (ter palavra e honra) é o desdobramento do movimento de singularizarse e coletivizar-se.

Esse aprendizado do etos prisional leva à incorporação dos valores da cadeia, daí, como sugeri acima, a necessidade de nomeação, a exigência pessoal de contar a história de seus companheiros, o "inferno" de cada um deles, o sentimento premente de narrar o que foi capaz de observar.

Ao terminar seu último capítulo, sentencia que "Um homem nunca é o mesmo depois da cadeia" (p. 171) e, com isso, acentua o caráter único da experiência prisional. Ao escrever "um homem", compartilha o que viveu e redimensiona seu relato, que é seu, mas é também de outros, como daqueles "manos" mencionados por ele na página seguinte a essa, justamente na seção "Um salve aos manos".

Assim, Diário de um detento pode ser lido a partir de uma primeira chave de leitura: a existência de um olhar duplo, que ora adere à perspectiva prisional, ora prefere aproximar-se da dos chamados "homens livres".

Essa tensão que atravessa todo o livro não impede que os princípios norteadores da vida no cárcere façam-se presentes na disposição que Diário de um detento assume, com as suas pequenas seções. Essa segunda chave de leitura remete, novamente em veio duplo, à escolha do livro, objeto usualmente associado ao ambiente dos "homens livres", que aqui é transformado de modo a não trair o etos prisional. Dessa forma, a escolha do livro está necessariamente associada à sua adequação aos valores e às condutas que se mostram presentes tanto no texto como na organização de Diário de um detento - os valores e as condutas do cárcere.

\footnotetext{
${ }^{47}$ A necessidade de retribuir está ligada à honra, como sugeriu Marcel Mauss em seu "Ensaio sobre a dádiva". Na cadeia, em que a honra é um dos mais altos valores, essas imposições não deixam de aparecer. "A dádiva não retribuída ainda torna inferior quem a aceitou" (Marcel Mauss, "Ensaio sobre a dádiva", p. 294) ou ainda: “(...) aceitar sem retribuir, ou sem retribuir mais, é subordinar-se, tornar-se cliente e servidor, ser pequeno, ficar mais abaixo" (idem, p. 305).
} 
Essa ambivalência narrativa parece-me própria de seu lugar de enunciação, a prisão, de onde Jocenir lançou com precisão o verso em forma de questão que carrega de significados a idéia de uma escrita da violência: "Mas quem vai acreditar no meu depoimento?".

\section{V.1.}

A prosa de Jocenir obedece, no geral, a uma estrutura fato-comentário. Narra a ação e, em seguida, a comenta. Alguns aspectos internos a essa formalização merecem olhar detido.

No que concerne à análise de estilo, é possível encontrar em sua prosa elementos que remetem à estrutura folhetinesca, em que se destaca o anúncio de desdobramentos, apenas futuramente revelados: "Esta foi a última vez que os vi [refere-se a Nego Nardo e Adrenalina, dois presos que o haviam surrado na Cadeia Pública de Barueri]. Mas Adrenalina, algum tempo depois, cruzaria meu destino de maneira trágica” (p. 51).

O fim de um capítulo que posterga revelações, apontando para o que viria a seguir, é ilustrativo: "Em meados de 1996, fui surpreendido por um fato muito interessante em razão de meu gosto por escrever versos" (p. 98).

Só se sabe a que fato remete no capítulo subseqüente, não por acaso intitulado "Um visitante chamado Mano Brown", quando trava conhecimento com aquele que o projetaria como compositor.

A mesma estrutura se repete ao longo do livro: "Em meados de 1998 eu cumpria pena na penitenciária de Avaré. E foi lá que talvez tenha ocorrido o fato mais curioso e trágico da minha passagem pelo sistema carcerário. Entretanto só mais tarde é que fui tomar consciência da dimensão inusitada deste acontecimento" (p. 143).

Há parágrafos constituídos de uma única frase e que também contribuem para prender o leitor à revelação do que não é dito em um primeiro momento: "Uma vez aconteceu comigo" (p. 125).

A incorporação de uma estrutura narrativa consagrada vem entrelaçada a construções sintáticas que podem remeter à oralidade (aqui, percebida na repetição: "Facas nas cinturas. Todos tinham facas na cintura", p. 138), bem como à criação de termos não pertencentes ao registro culto da língua e cuja autoria não é necessariamente sua, mas fruto 
de sua passagem pela prisão (“[...] queriam subir com o referido elemento ${ }^{48 ", ~ p . ~ 144, ~ g r i f o ~}$ meu).

A sintaxe peculiar muitas vezes está a serviço da escrita dirigida primordialmente para os que não compartilham os códigos da cadeia: "Laranjas. São presos que assumem a autoria de crimes que não cometeram" (p. 95) ${ }^{49}$. De algum modo essa construção alude à dos próprios capítulos, cujas epígrafes dão mote ao que será narrado em seguida. “Laranjas" é o mote. Sua explicação vem em seguida.

A interrupção da narrativa para esclarecer alguns termos aos leitores é igualmente constante: "Ele queria receber e ainda mandar o Erick para o Seguro, no pavilhão Cinco./ O Seguro é um lugar para onde vão os presos que correm risco de vida. É a maior fábrica de laranjas da Detenção" (p. 119). Tendo explicado algumas páginas antes o que "laranja" queria dizer, basta que explique o que é o "Seguro".

A linguagem assume tom informativo quando, no último capítulo, prestes a deixar a cadeia, sente-se compelido a esclarecer, estabelecendo, pelo emprego do conectivo, uma relação de sentido, só possível porque adere ao que chama de "tradição dos presídios": “(...) pois é da tradição dos presídios doar todos os objetos de uso pessoal para aqueles que ficam, um preso quando ganha as ruas normalmente leva só a roupa do corpo e as correspondências acumuladas em sua passagem" (p. 167, grifo meu).

A ausência de subordinação, normalmente associada a construções mais simples, faz-se igualmente presente: "Alguns presos estavam endividados. Droga. Resolveram me extorquir. Diziam que eu não era bandido, nem ladrão. Não era digno de viver entre eles” (p. 45). O uso dos períodos breves, que prescindem de conjunções reveladoras de sentido, é extremamente adequado à situação: Jocenir, que ao longo de todo o livro argumenta que sua prisão foi injusta, reitera o seu não pertencimento àquele ambiente corrompido $^{50}$ dos falsos malandros quando, recriando a situação, atribui aos outros a

${ }^{48}$ Aqui, é digno de nota que as gírias dos presidiários muitas vezes incorporam termos e expressões do jargão policial, como "elemento".

${ }^{49}$ Curiosa aqui é a necessidade de explicação do termo "laranja", gíria que pertence ao mundo dos "homens livres”, ainda que para indicar ato de infração. O laranja, na prisão, não é o que assume a compra de algo que não adquiriu, mas a autoria de um crime não cometido por ele - nesse sentido, tem seu sentido aprofundado.

${ }^{50}$ Esse episódio, ocorrido durante sua passagem pela Cadeia de Barueri, revela uma distinção reiteradas vezes anunciada pela "literatura carcerária" entre os "falsos malandros" (que não seriam bandidos de verdade e, para tentar suprir essa "lacuna", oprimiam os recém-chegados cujos laços com a "comunidade" não parecessem suficientes para protegê-los) e os "verdadeiros malandros" (aqueles que habitavam os presídios, tinham penas longas e eram respeitados por seus pares). Os verdadeiros malandros, adeptos do 
identidade que reivindicava para si: "Diziam que eu não era bandido, nem ladrão". Mas quem infringia o código de conduta eram os que the diziam aquilo, uma vez que a extorsão é prática condenada nos presídios. Ao recriar a fala dos que o ameaçavam, Jocenir o faz de modo a evidenciar a inadequação, no ambiente da cadeia, do que lhe diziam os "falsos malandros". A ameaça não era vista como correta naquele universo, o que pode indicar que a narrativa da cena traz em sua sintaxe a ausência de conectivos causais, justamente pela incapacidade de, em acordo com o etos do cárcere, conferir explicação àquela extorsão. As lacunas explicativas podem ser lidas como o modo de Jocenir, tendo introjetado as regras de conduta da prisão, refutar um discurso e uma prática não reconhecidos como dignos à cadeia.

À medida que se aproxima do fim, a narrativa se concentra na espera ansiosa do alvará de soltura: "Meu coração batia descompassado, pedia para sair do peito, pedia para sair do presídio" (p. 164). À estrutura em paralelo deve ser dedicada atenção. Com o coração que pedia para sair do peito, o leitor vê-se novamente às voltas com o clichê. Trata-se, contudo, do mesmo coração que pede para sair do presídio. O emprego do lugarcomum nesse trecho pode ser pensado de dois modos: lançando mão dele, aproxima a situação de seu público-alvo, que não sabe o que é o desejo de liberdade ("Quando se está em liberdade essas coisas [botar os filhos na cama, dar-lhes boa noite, abraçar a companheira e beijá-la] parecem não ter tanto valor", revela Jocenir um pouco adiante, ainda à página 164), mas é capaz de, pelo reconhecimento do clichê, imaginar uma dada situação. O acréscimo de um "coração que pede para sair do presídio", além de transformar o "peito" anteriormente mencionado em uma "prisão" no sentido figurado, contribui para, agora, tendo deixado o leitor mais ou menos próximo de uma circunstância conhecida (a do clichê), trazê-lo para a especificidade da sua sensação e situação.

Nesse sentido, novamente o lugar-comum é incorporado ao texto, mas em sua negatividade - trata-se de um recurso para tentar fazer-se entender por alguém que não compartilha a linguagem do cárcere, mas que é capaz de compreender a expressão-clichê. $\mathrm{O}$ uso do dito compartilhado parece ser uma tentativa de, mobilizando a linguagem esgotada do lugar-comum, fazer entender a não-banalidade da sua experiência, torná-la mais próxima do leitor.

código de conduta dos próprios presos, vêem a extorsão como uma prática vil. 
À página 76, lê-se: "Ironizavam com nossos ossos quebrados, nosso sangue que escorria, nossas roupas rasgadas, nosso desespero. Preparavam uma maldade policialesca. Algo bem podre e condizente com eles" (p. 76, grifo meu).

O adjetivo empregado - "policialesca" - poderia parecer redundante, visto que quem cometia as barbaridades narradas eram policiais, mas o termo escapa ao exagero, não só porque a situação narrada é desmedidamente brutal e, portanto, qualquer acusação de "exagero" será leviana, mas porque sugere que atos tão covardes são próprios de policiais. Os ossos quebrados e o sangue que escorria não são apenas revelados, mas vêm acompanhados do verbo "ironizar", aqui, de um descaramento ímpar. As roupas rasgadas e o desespero acentuam a crueldade do quadro. Nesse plural sem nomes, os policiais são reduzidos a um "eles" sem cara, não reconhecíveis, o resumo do horror, tanto que os verbos "ironizavam" e "preparavam" ficam sem sujeito explícito, a sinalizar uma separação abissal entre "nós" e "eles". Não há adesão possível a esse "eles", porque eles são o contrário do que é entendido como próprio ao "mundo dos homens livres", embora, na prática, sejam por esse mesmo mundo engendrado e autorizado.

Nesse sentido, colocar "policialesca", termo sugestivo de seu local de enunciação (que nega o respeito à força policial), ao lado do culto "condizente" é um gesto resistente à violência infligida, em que o narrador, sem recusar sua condição (circunstancial) de homem preso, incorpora a língua do agressor para fazer notar que sua condição circunstancial não o torna bestial.

As leis institucionais da prisão, aquelas também não escritas, mas praticadas pelos seus responsáveis, como carcereiros, guardas, diretores, não têm espaço na literatura carcerária, porque os homens presos não as reconhecem como legítimas. Se adesão há - e minha aposta é de que ela exista -, ela se dá entre a efetividade dos códigos criados pelos próprios presos e a normatividade da conduta dos homens livres, ou seja, na aposta de que o etos do lado de fora exista tal qual imaginado.

\section{V.2.}

Diário de um detento é o único livro de Jocenir, autor ainda de um conto publicado no suplemento "Literatura Marginal", organizado por Ferréz e editado sob o selo da revista Caros Amigos. 
A partir de seu livro, constrói para si uma imagem - a de escritor - que vai na contramão do que o senso comum poderia esperar de alguém "oriundo" 51 das prisões. Sua escrita é construída sobre valores muito bem definidos, que são os seus a partir da experiência prisional, portanto, presumem um antes e um depois. A idéia do aprendizado igualmente supõe uma condição prévia (homem livre) e ulterior (ex-detento). Entre esses dois momentos, passa pelo que a sociologia dos campos chama de ritos de instituição ${ }^{52}$ (e que Jocenir, apropriando-se do jargão dos presídios, nomeia como "processo de inclusão", quando os presos recebem uniformes, têm a cabeça raspada etc.), impostos pelo Estado, que, ao fazê-lo, determina uma nova identidade, a de presidiário ${ }^{53}$.

“(...) a investidura exerce uma eficácia simbólica inteiramente real pelo fato de transformar efetivamente a pessoa consagrada: de início, logra tal efeito ao transformar a representação que os demais agentes possuem dessa pessoa e ao modificar sobretudo os comportamentos que adotam em relação a ela (a mais visível de todas essas mudanças é o fato de lhe conceder títulos de respeito e o respeito realmente associado a tal enunciação); em seguida, porque a investidura transforma ao mesmo tempo a representação que a pessoa investida faz de si mesma, bem como os comportamentos que ela acredita estar obrigada a adotar para se ajustar a tal representação" 54 .

Como esse antes e depois aparecem no texto ${ }^{55}$ Observe-se um dos excertos em que Jocenir cria uma imagem de si:

"Nasci e fui criado em bairros de classe média, talvez por isso minha facilidade em notar que a história da grande maioria dos presos está absolutamente ligada ao estado de miséria em que se encontra nosso

\footnotetext{
${ }^{51}$ Há nesse discurso que ora incorporo, lançando mão das necessárias aspas, uma idéia muito reveladora do estigma que acompanha o presidiário, afinal ninguém pode ser originário da prisão.

${ }^{52}$ Ver Pierre Bourdieu, "Os ritos de instituição", em Economia das trocas lingüísticas. O ato de instituição, segundo Bourdieu, notifica a alguém - aqui o homem detido - a sua identidade (de presidiário).

${ }^{53}$ Ver Michel Foucault, "Sobre a prisão", em Microfisica do poder.

${ }_{55}^{54}$ P. Bourdieu, op. cit., p. 99.

${ }^{55}$ M. Foucault, em seu Vigiar e punir, atenta para a importância do elemento biográfico na história da penalidade: "Porque ele faz existir o 'criminoso' antes do crime e, num raciocínio-limite, fora deste" (p. 224).
} 
povo. Miséria brava, patrocinada pelo mesmo sistema que trancafia as pessoas em celas" (p. 108).

O narrador posta-se aqui como observador privilegiado ${ }^{56}$. Indicando um antes, temse, então, segundo sua formulação, a sua origem social distinta à da grande maioria dos presos, bem como a capacidade de enxergar o que outros não vêem.

O depois é percebido no modo como vai, enquanto está preso, transformando-se em autor, sendo assim reconhecido por seus pares (que legitimam sua escrita, quando lhe pedem versos e cartas para a família) e por ele mesmo (quando constrói para si a imagem de alguém que tem intimidade com as palavras, em função de um dom que outros também enxergam nele).

Em um segundo momento, sua escrita é reconhecida externamente por Mano Brown (responsável pela comunicação com os de fora), com quem assina música de sucesso, a qual lhe rende a publicação do livro (portanto, a chancela de uma, ainda que pequena, editora). Nesse movimento, torna-se um compositor e escritor, com ouvintes e leitores.

Jocenir preocupa-se em produzir uma escrita que seja leal aos valores aprendidos na prisão, de modo a não falsear a experiência, a não deixar cair no esquecimento as brutalidades sofridas por ele e pelos companheiros, mas também para memorar as suas histórias. Nesse sentido, incorpora a identidade recebida (a de presidiário), mas não a deixa reduzir-se ao que dela é esperado: valoriza a sua experiência, a dos outros, confere nome e dignidade aos que com ele compartilharam o cárcere, conforma seu livro de modo a exaltar essa subversão identitária.

Ao mesmo tempo, ao fazê-lo, cria uma identidade autoral que lhe é única - é ele quem assina o livro, foi ele quem compôs a letra -, que pode significar a legitimação de seu discurso e, em última instância, uma possibilidade de (re)inserção social. Mas a ambigüidade está dada: pois se precisa ser fiel à experiência - e um "homem nunca é o mesmo depois da cadeia" -, a marca permanece, não pode se furtar a escrever sobre isso e como o etos prisional exige, sob risco de ser deslegitimado pelos antigos companheiros.

\footnotetext{
${ }^{56}$ Essa posição é partilhada, segundo as suas próprias formulações por Humberto Rodrigues (em função de sua origem social) e, em razão dos anos de prisão e das leituras feitas, por Luiz Alberto Mendes. Já André Du Rap vê-se como alguém a quem foi dado o dom da escrita e, sobrevivente, portanto, em dívida, precisa fazer uso dessa dádiva.
} 
Em sua adesão ambivalente a códigos de conduta distintos, a partir de um uso dobrado da linguagem, a prosa de Jocenir quer provar a sua autenticidade. Essa dimensão remete-nos ao relato de Primo Levi da "cena sempre repetida [em seus sonhos] da narração que os outros não escutam" 57 . No caso da "literatura carcerária", a suposição de que não o escutem aparece, já de início, pela condição a ele atribuída de marginal. Em um segundo momento, porque narra os horrores decorrentes de ter recebido o título de marginal: brutalidade policial, covardia dos carcereiros, condições desumanas. De tão assustadores, podem soar inverídicos, sobretudo se assinados por quem já se mostrou capaz de infringir os preceitos da vida civilizada em sociedade. Sob esse duplo risco, Jocenir conforma sua narrativa à busca da credibilidade, seja pela nomeação (presente nos agradecimentos, no salve aos manos), seja pela fotografia, seja pela carta fac-similada, seja pela apresentação feita por um médico respeitável e conhecido.

Nesse sentido, seu livro é leal aos preceitos da vida no cárcere, porque se propõe a não falsear a verdade, não descumprir a palavra e manter intacta a sua honra. Como o é também ao mundo dos homens livres, quando, reconhecendo-o como instância legitimadora, confere ao papel, à escrita, à prova, a autenticidade da experiência.

\footnotetext{
${ }^{57}$ Primo Levi, É isto um homem?, p. 60. No livro Lembrar escrever esquecer, Jeanne-Marie Gagnebin analisa em alguns de seus ensaios a repetição e a importância dessa cena (ver, por exemplo, "Memória, história, testemunho" ou "Verdade e memória do passado").
} 


\section{Capítulo 2 (ou "Ninguém sabe o peso que tem uma grade")}

I.

Sobrevivente André du Rap (do Massacre do Carandiru), lançado no segundo semestre de 2002 pela mesma editora de Diário de um detento, a Labortexto Editorial, impunha-se desde o início desta pesquisa como um objeto de difícil enfrentamento, não só pelo impressionante relato que continha, o de um sobrevivente ao Massacre do Carandiru, mas também porque se tratava de um livro escrito a quatro mãos. De todos os livros que constituem o corpus deste trabalho, Sobrevivente é o único com esse perfil ${ }^{1}$. José André de Araújo, que, assim como Jocenir, adotou um pseudônimo - André du Rap -, escreveu seu

livro com o jornalista Bruno Zeni. Resultado de um encontro durante o julgamento do coronel Ubiratan Guimarães ${ }^{2}$, o livro de André e Bruno nasce de uma dupla necessidade de narrar o que houve em 2 de outubro de 1992: para que não fossem esquecidos os seus mortos e para que "aquilo" não voltasse a se repetir. ${ }^{3}$

Também ao contrário dos outros livros aqui discutidos, o de André e Bruno nasce de quatro sessões de conversas gravadas e tem como razão de existência a narrativa de Du Rap sobre o Massacre ${ }^{4}$. Não nasce, portanto, da escrita ${ }^{5}$, mas da fala em registro dialógico

${ }^{1}$ Enjaulado, de Pedro Paulo Negrini, conta a história prisional de Rogério Aparecido e, nesse sentido, poderia se assemelhar a Sobrevivente André du Rap, mas algumas observações de Negrini, que se nomeia "autor do livro", a respeito de seu papel afastariam os dois volumes. Afirma, por exemplo, que: "O autor, embora dando sua própria redação às idéias de Rogério, tentou ser o mais fiel possível ao que lhe foi exposto, colocando no texto o linguajar da cadeia, quando tal foi viável. As conversas havidas entre Rogério e o autor - que possui experiência profissional adquirida como advogado criminalista por muitos anos possibilitaram que este livro fosse escrito" (p. xvi, grifos meus). Márcio Seligmann-Silva aponta as diferenças entre os dois livros, ao mesmo tempo em que marca o papel de Zeni: "Bruno Zeni, como jornalista, literato e estudioso de literatura, encontra-se à parte neste grupo de escritores e tem também um papel sui generis na sua parceira com André du Rap, diverso do de Pedro Paulo Negrini com relação ao exprisioneiro Rogério Aparecido, já que Zeni optou por uma elaborada estratégia de 'intervenções mínimas' no relato de André du Rap" ("Violência, encarceramento, (in)justiça", op. cit., p. 11).

${ }^{2} \mathrm{O}$ coronel Ubiratan Guimarães era acusado de ser o responsável pela operação de invasão à Casa de Detenção de São Paulo, o Carandiru, em 2 de outubro de 1992, quando foram mortos, segundo os dados oficiais, 111 presos.

${ }^{3}$ Como se vê adiante, André muitas vezes se refere ao Massacre como "aquilo". Sobre sua urgência em narrar: "Minha intenção é alertar a sociedade do que pode acontecer. Que o que aconteceu pode acontecer de novo. Um novo massacre" (p. 106).

${ }^{4}$ Nesse sentido, talvez se assemelhasse a livros do testimonio latino-americano, como Meu nome é Rigoberta Menchú - e assim nasceu a minha consciência, mas, aqui também, a experiência prisional brasileira dota o livro de especificidades. Além disso, ao contrário do que ocorre naquele livro, no de André e Bruno, ambos respondem pela autoria (o de Rigoberta é assinado por Elizabeth Burgos).

${ }^{5}$ Esse ponto não parece ser pacífico entre os dois autores. Na ocasião do lançamento do livro, ambos concederam entrevistas ao jornal Folha de S. Paulo em que expressavam divergências a esse respeito. Referindo-se à seção "Fragmentos de uma correspondência", Bruno comenta que "Essas cartas são o único lugar no livro em que tem, de fato, a escrita dele; o resto é a nossa conversa" ("Sobrevivente relata o 
entre seus dois autores. É sob essa ótica que deve ser analisado - é nisso que se diferencia dos outros volumes discutidos neste trabalho e é também a partir dessa dupla elaboração que constrói a sua particularidade. De um lado, André, recém-saído de quase uma década aprisionado, tentando refazer a vida, mas precisando se haver com seu passado. De outro, Bruno, já autor (O fluxo silencioso das máquinas, pela Ateliê Editorial, 2002), jornalista e então mestrando em Teoria Literária nesta Universidade. Tinham, portanto, trajetórias muito distintas, provenientes de classes sociais igualmente díspares e haviam recebido graus bastante variados de educação formal. Bruno detinha as possibilidades rápidas, fruto de sua inserção nos meios editoriais como jornalista e como editor, de publicação do relato de André, mas não conhecia a experiência-limite vivida por ele.

Embora na capa e na ficha catalográfica Bruno apareça como responsável pela "coordenação editorial", no final do livro ambos são "os autores" (ver seção "Sobre os autores"). São ainda de autoria de Zeni as notas de rodapé, a apresentação e o ensaio que fecha o livro. Se a história narrada é a de André, era de se supor, por todas as intervenções de Zeni e por seu ensaio, que ele respondesse pela forma do livro, ainda que ele a atribua ao que reconhece como sendo de André: as fotos, as cartas, a história, a autoria. No último item deste capítulo, procurarei discutir essa questão.

Nesse sentido, a questão da inserção pela autoria, tal qual a discuti no capítulo anterior, deve ser vista a partir dos novos contornos impostos por esse livro. Para pensá-la, acredito que seja necessário enfrentar, em um primeiro momento, passada a descrição do objeto, o modo como a história de André assume uma forma narrativa, como é feita a apropriação do livro, em que pese a formação acadêmica de um dos autores. $O$ ensaio de Bruno indica pistas interpretativas para o seu próprio livro, como procurarei destacar mais adiante.

Sobrevivente André du Rap, a seu modo específico, comunga dos valores expressos nos outros livros da chamada "literatura carcerária", que, por sua vez, remetem ao ambiente de onde provêm - a prisão. A matéria narrativa, construída a partir de qualidades como lealdade, humildade, solidariedade, professadas à exaustão por André, é na maior parte das

massacre do Carandiru”, Folha de S. Paulo, 09/09/02). Já André, ao responder ao repórter se havia sido difícil publicar o livro, afirma: "Desde que eu comecei a escrever as primeiras páginas" ("Decidi fazer da experiência terrível algo bom”, Folha de S. Paulo, 09/09/02). Tomo aqui, para efeitos de análise, como não poderia deixar de ser, o que o livro afirma: o que há ali é resultado de quatro entrevistas gravadas. 
vezes o relato da experiência na prisão, mas também o rememorar ${ }^{6}$ da vida para além do "peso da grade", para usar sua expressão sobre o cárcere. Nesse sentido, aqui também, a exemplo do que percebi na prosa de Jocenir, é possível notar a adesão do discurso de André a um conjunto de regras e valores do ambiente prisional, mas também, em outros momentos, a expectativa de diálogo com o mundo exterior, do qual, no momento de concepção do livro, Du Rap já fazia parte (ao menos idealmente, como ele próprio deixa entrever quando discute o estigma do ex-presidiário). A origem do livro, o encontro dos dois, contribui para esse vislumbrar do mundo dos "homens livres", do qual Zeni é inconteste membro.

No Capítulo 1, dedicado à análise de Diário de um detento, o movimento de singularizar e ampliar a experiência, que ora era apenas de Jocenir, ora era feito em nome de todos os seus companheiros, dava-se primordialmente em função do trato com a escrita. A identidade prisional de Jocenir, a partir da qual construirá uma identidade para depois, ganhava contornos específicos graças a essa habilidade. No caso de André, esse ponto, também presente em seu livro, torna-se mais complexo: reconhece-se, como Jocenir, alguém a quem foi dado o "dom da palavra" (nem sempre escrita, muitas vezes cantada, falada, como se verá adiante), mas a sua identidade prisional não pode escapar à sobrevivência ao Massacre. Esse movimento de singularizar e compartilhar a experiência da prisão deve-se em muito, embora não somente, aos companheiros mortos (ele sobreviveu, outros muitos morreram, mas, como ele, outros que estavam lá também estão vivos).

No trecho que segue, é possível ter uma idéia do modo como se condensam essas questões para André: "A sociedade aqui fora é totalmente diferente do nosso mundo, do mundo que você vive atrás das grades. Ninguém sabe o peso que tem uma grade" (p. 186). Já no primeiro momento, falando como homem livre (o "aqui fora" é o "mundo dos homens livres" afinal), reitera seu pertencimento ao ambiente prisional ("nosso mundo"),

\footnotetext{
${ }^{6}$ Entende-se aqui rememorar na acepção benjaminiana, de acordo com Jeanne-Marie Gagnebin: "Tal rememoração implica uma certa ascese da atividade historiadora, que, em vez de repetir aquilo de que se lembra, abre-se aos brancos, aos buracos, ao esquecido e ao recalcado, para dizer, com hesitações, solavancos, incompletude, aquilo que ainda não teve direito nem à lembrança nem às palavras. A rememoração também significa uma atenção precisa ao presente, particularmente a estas estranhas ressurgências do passado no presente, pois não se trata somente de não se esquecer do passado, mas também de agir sobre o presente. A fidelidade ao passado, não sendo um fim em si, visa à transformação do presente" ("Memória, história, testemunho", p. 91).
} 
compartilhado apenas com os seus pares. Ao continuar, toma o "você" no lugar do "nós" antes empregado, de modo a tornar o que vai dizer mais próximo de seu interlocutor, ao mesmo tempo em que, momentaneamente, deixa de se inscrever (ele já não está mais preso). Quando comenta que "ninguém sabe o peso que tem uma grade", esse ninguém evidentemente refere-se aos que estão "aqui fora" e que nunca estiveram lá dentro. Atrela o conhecimento do "peso da grade" (entendido como o sofrimento que ultrapassa os anos de confinamento) à verdadeira experiência. Só quem viveu é capaz de narrá-la e talvez de compreendê-la. Mas quem viveu, sugere André, não deixa de sentir-se na prisão com tudo o que ela implica: dos valores preservados (o que the parece positivo) ao estigma do bandido (visto, evidentemente, como um problema, embora faça questão de não negar essa identidade).

Faço, no próximo item, a apresentação do livro, para em seguida olhar mais detidamente para a seção "Free Style" (item III), que de algum modo reproduz a estrutura do volume, e para o capítulo inicial do livro, em que André fala sobre o Massacre (item IV).

\section{II.}

A capa de Sobrevivente André du Rap é uma foto em preto-e-branco de André, também reproduzida no caderno de fotografias do livro, no pátio do Pavilhão 8 do Carandiru. Tirada em 2001 por Bruno, mostra ainda outros três homens ao fundo. O título traz esclarecimento do caráter de "sobrevivente" - referência ao Massacre, já sugerida pela imagem do presídio, facilmente identificável com suas janelas gradeadas e com as roupas dependuradas. Não há menção a autor, mas a foto de André parece funcionar como indicadora da identidade do dono daquela história. Em letras bem menores, a indicação de que a coordenação editorial é de Bruno Zeni.

A página 5 é inteiramente tomada por fotografias (reprodução de contatos fotográficos), também em preto-e-branco, do rosto de André. Se vistas com atenção, deixam notar a presença de cicatrizes na testa, no queixo e acima do olho. 


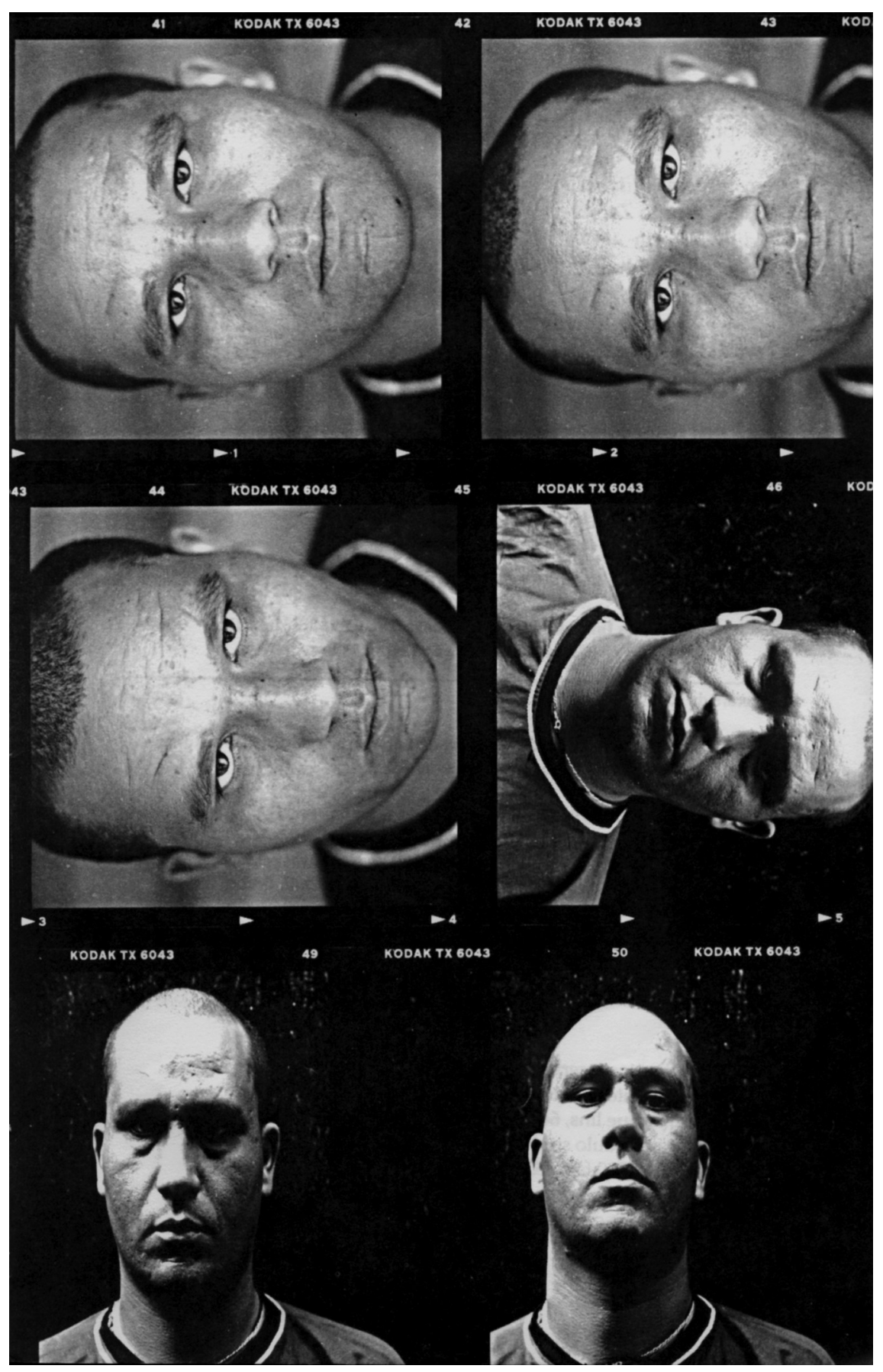

Em seguida, lê-se a dedicatória ${ }^{1}$. A reverência de André aos amigos, que perpassará todo o livro, aparece na homenagem póstuma a Natanael Valêncio, a quem chama de "irmão": "descanse em paz".

\footnotetext{
${ }^{1}$ A dedicatória é um item presente em três dos quatro volumes que compõem o corpus desta pesquisa. Deve ser compreendida, portanto, como aspecto formal estruturador dos livros aqui analisados, como procurarei discutir adiante.
} 
Às páginas 9 e 10, Bruno Zeni apresenta a estrutura do livro. Afirma que ele está dividido em quatro partes (exclui do rol das partes o seu texto, que funciona como um posfácio). Para Bruno, apenas as partes iniciais são a matéria narrativa do livro: "Depoimento" ("transcrição das quatro sessões de entrevistas feitas [por ele] com André du Rap"); "Fragmentos de uma correspondência" (reunião de algumas cartas escritas e recebidas por André); "Free style" ("trechos do relato que André gravou sozinho"); e "Aliados" ("companheiros de hip-hop e de luta social falam sobre a convivência com o autor"2).

Essa apresentação funciona como uma explicitação metodológica dos procedimentos adotados por Zeni. Afirma ter sido ele o responsável pela edição do "Depoimento", que parte de escolhas suas quanto à necessária adequação forma-conteúdo. Conta que respeitou a ordem do relato de André - só mexeu na narrativa do Massacre, que trouxe para o início, e que suprimiu as "perguntas e outras intervenções que f[e]z durante as (...) conversas": "Na edição do texto, procurei ser o mais fiel possível às particularidades da fala de André - mantive inclusive suas incongruências e incorreções - por acreditar que não se pode separar a forma e o conteúdo daquilo que se diz, escreve ou cria" (p. 9). Essa sugestão será reforçada pela presença das notas de rodapé ao longo de todo o volume, pelos procedimentos próprios de arquivista na seção das cartas, bem como pelo próprio ensaio, que se dispõe a analisar o material.

Na apresentação da seção "Free Style (de improviso)", à qual dedicarei análise mais minuciosa no próximo item, Bruno comenta: "Escolhi trechos do relato que André gravou sozinho", evidenciando ter sido sua a escolha a partir de um relato espontâneo de André. Explica o "free style" do título e depois afirma: "Acho que é uma definição justa para o depoimento que André fez com toda liberdade, sem a minha mediação", que, no entanto, está dada no momento em que é ele quem atribui um título que remete ao hip-hop (ambiente de André) e que submete o improviso à edição. ${ }^{3}$

\footnotetext{
${ }^{2}$ Note-se que Bruno, nesse excerto, chama André de autor do livro (o que ganha maior peso quando se percebe que Bruno assina todas as partes que considera suas, notadamente, a apresentação - que não chega a ser assim chamada - e o ensaio-memorial ao final).

${ }^{3}$ Não se pode perder de vista, no entanto, que, no "Depoimento", o próprio André comenta o nome dado a essa prática de improviso: "A gente fazia o que hoje se chama free style, um mandava uma rima, outro mandava também” (p. 48).
} 
A primeira parte - ou "Depoimento" - é dedicada ao relato da vida de André na prisão, incluindo o trecho, que abre o livro, em que dá o seu testemunho do dia do Massacre. Dividido em sete pequenos capítulos, conta o cotidiano da cadeia, as relações amorosas, a vida de foragido antes de ser preso, o trabalho com o hip-hop na cadeia. O relato do Massacre é, junto à tumultuada relação com a namorada Eliana, o ponto central ao qual André volta com freqüência.

Ao longo desses capítulos, são objeto da atenção de André a linguagem e o etos prisional, a relação com a escrita (que, aqui, é entendida de modo ampliado: as cartas que escreve e recebe, as letras de rap que compõe), o estigma de ser um ex-presidiário e a experiência-limite pela qual passou.

A percepção de que não se dirige a um conhecedor das cadeias (justificada pela presença de Zeni) aparece na preocupação em explicitar as gírias empregadas: "Fui pago no pavilhão de triagem, o Nove. Na linguagem da cadeia, a gente fala assim: fui pago" (p. 45) - conta André, sem de fato esclarecer o que vem a ser, nessa acepção, o verbo "pagar"4. Ou: "Estou vendo chamar meu nome lá na boca de ferro, como é chamado o serviço de locução" (p. 75).

Tal preocupação, como já disse aqui, poderia parecer óbvia, uma vez que o livro parte do encontro de André, que esteve preso, com Bruno, que jamais passou por experiência semelhante. Mas interessa-me pensar na manutenção dessas marcas de explicação, que se repetem significativamente e que sugerem a intenção de esclarecimento de um ambiente desconhecido.

Essa apreensão é vista também quando André explicita os valores que norteiam a vida prisional, por exemplo, quando reproduz o que, à sua chegada ao Carandiru, lhe teriam dito na cela ("o 69-E")): "Você demonstrou ser um cara humilde, pode ficar morando aqui com a gente" (p. 46). Ainda: "Dentro do sistema penitenciário existe muita solidariedade (...)", "A gente pega muito isso, a irmandade, a lealdade" (p. 51). Chega a sugerir que tais valores estejam mais presentes na prisão do que no mundo dos homens livres: "O que muitas vezes não existe aqui fora, existe lá dentro" (p. 51). Note-se que aquilo que para

\footnotetext{
${ }^{4}$ No Capítulo 5, discuto, um comentário de Luiz Alberto Mendes sobre esse verbo.

${ }^{5}$ André sempre que pode indica o número de sua cela, o que pode ser lido como mais um recurso para atestar que de fato esteve lá, afinal, são dados que podem ser comprovados. Assim como fará Humberto Rodrigues com o número de prontuário seu e dos companheiros.
} 
Jocenir era o "mundo dos homens livres" para André é o "fora", como se o seu "dentro", mesmo em liberdade, remontasse à prisão.

Essa idéia é várias vezes reiterada na narrativa de André:

"Dentro do sistema penitenciário, dentro da cadeia, a gente tem o maior respeito, todos os companheiros têm o maior respeito. Não existe lugar no mundo onde existe maior solidariedade. (...) Isso é companheirismo, é de irmão mesmo. Quando a gente fala assim, companheiro, irmão, é que muitas vezes aqui fora não tem isso" (p. 100).

Há, inclusive, a percepção de construção de um etos próprio: “(...) dentro do sistema carcerário, a gente tem essas regras. A lealdade, o respeito, a dignidade. Se você mexer com a dignidade de um homem, você está mexendo com toda estrutura dele. (...)" (p. 111).

O modo de funcionamento do presídio é ditado pelos presos, como já se viu no livro de Jocenir. Quem ensina o código aos que chegam são os outros detentos: "Quando a gente chega no presídio, os companheiros já explicam como funciona. Mas tem que ficar atento. (...) Dentro da cadeia, a prioridade é o respeito" (pp. 49-50).

O valor da palavra empenhada também se faz presente ao longo de "Depoimento": "Uma palavra errada que você falar, você pode estar se condenando" (p. 55). Esse fragmento é bastante revelador da idéia de que, uma vez na prisão, o código a ser seguido é o dos próprios detentos - são eles que aplicarão a pena se falha houver. A construção faz refletir, também, porque lança mão do termo "condenar", o que sugere a reprodução, entre os presos, de mecanismos de justiça (como o instituto da "condenação") que são próprios, mas não exclusivos, do mundo dos homens livres.

A relação com a escrita está no rol dos assuntos tocados por André, que conta ter usado o seu tempo para escrever versos, como também para redigir cartas, o principal meio de comunicação com o "mundo exterior":

"Eu fazia minhas atividades, fazia limpeza, passava pano, cozinhava, subia pra jega e começava a escrever. Jega é a cama. Jega ou burra - é o linguajar lá de dentro. Subia e ficava olhando pro mundão pela ventana. 
Escrevia, muitas vezes escrevia pra minha mina (...). Eu sempre escrevia cartas. Ficava na esperança de vir alguém pra mandar aquela carta. Se você não tivesse visita, você não podia descer do andar. (...) Praticamente eu não tinha pra quem escrever nessa época. Minha família tava revoltada com o que tinha acontecido. Escrevia pra Bertioga [para Soraia, sua namorada na época], não vinha resposta. Eu escrevia, escrevia e não tinha resposta. (...) [Não podendo descer para o pátio no dia da visita] $\mathrm{O}$ único conforto que eu tinha era a caneta e o papel. Escrevi muitos poemas nessas horas" (pp. 47-48).

As cartas têm papel fundamental na história carcerária de André - e parece ser essa a razão para que um livro dedicado à narrativa desse período de sua vida as incorporasse, como se vê na seção "Fragmentos de uma correspondência". A relação com o mundo exterior, que, afinal, pauta a vida na cadeia, determina o elo entre as duas formações sociais (cadeia e mundo exterior).

A possibilidade de criação artística é apontada como um alento à vida no cárcere:

“[Na cadeia $]$ Tudo é conteúdo, é só você pegar, encaixar as coisas, 'Isso aqui dá legal pra mim, é um personagem'. É assim, o dia-a-dia. Tem um lado bom. Não é bom estar preso, mas o lado bom, que a gente fala, é a noite, quando você está livre de tudo. Este é o lado bom, eu me sentia livre. A todo momento você se sente livre. Em pensamento, em pensamento. Mas o momento em que você se sente mais livre é quando você está dormindo" (p. 54).

A escrita é vista como possibilidade de evasão temporária de uma situação perturbadora e constritora. A liberdade - "livre", Andre afirma e reafirma - só pode vir em pensamento (o termo também é repetido), a instância não vigiada e o espaço momentaneamente não compartilhado.

Quando André relata que, durante o julgamento do coronel Ubiratan, reencontra companheiros de Carandiru que também sobreviveram ao Massacre, afirma não poder se esquecer do caráter único da experiência-limite: "O que nós passamos ninguém mais 
passou" (p. 103). Diante do medo de alguns detentos, sobretudo os que ainda estavam presos, em testemunhar e serem mortos, no que André não via exagero algum (em clara denúncia da violência de que continuavam sendo vítimas: tendo sobrevivido ao Massacre, temiam novamente pela própria vida), comenta: "Eu quero falar a verdade, contar a minha história pra ela não se repetir" (p. 104).

Essa urgência narrativa vem perseguida pela possibilidade de incredulidade por parte daqueles que o lêem, daí, muito provavelmente, a necessidade da prova. Percebe-se aqui o que chamei no capítulo anterior de movimento de singularização e coletivização do vivido. Depois de sugerir aos amigos que "o que nós passamos ninguém mais passou", afirma: "Mesmo que eu não consiga provar, eu tenho que estar falando a minha verdade. É a minha verdade, é o que eu passei” (p. 111). Trata-se, portanto, da sua história (no que se singulariza), mas que em determinados momentos, como no do Massacre, confunde-se, sem perder a sua especificidade, com as de outros tantos companheiros do Pavilhão 9 de 1992. Incumbe-se, até porque não pode negar-se a isto, da tarefa de narrar em seu nome, mas também no de outros.

Nessa busca pela narrativa do passado, há uma incontornável expectativa de transformação identitária futura. Evidentemente, ela é ambígua. Se André precisa ser fiel à década em que esteve preso e em que comungou dos valores ali sustentados, o estigma de ex-presidiário (que, no entanto, como ele gosta de frisar "é parte da [sua] história" incomoda: "Antes de eu ser preso, eu era o André. Eu era o André que estudava, que trabalhava, eu tinha a minha família. À parte as intrigas de família, eu tinha uma família. A partir do momento em que eu fui preso, eu me tornei quem? Não o André, mas o bandido" (p. 106).

Portanto, assim como se viu que ocorria em Diário de um detento, nota-se que a narrativa de André é a história de um homem que passou pela experiência da prisão e que não se furta a dizê-lo. Mas é também a de um egresso da prisão, em busca de reinserção. $\mathrm{O}$ livro pode ter, em seu caráter ideal, esta função: aponta para a possibilidade de, sem negar a sua história, André tornar-se um autor.

\footnotetext{
6 "Mas eu não tenho vergonha de ser ex-presidiário, não. É a minha história. Acho que é por isso que essa história deve ser contada da maneira que aconteceu, porque é a história de cada um, ninguém se livra dela, ninguém tem outra pra contar" (p. 106).
} 
Todos esses aspectos - estigma, percepção da experiência como única, relação com a escrita e linguagem e etos prisional - reaparecerão ao longo do livro.

A seção seguinte - "Fragmentos de uma correspondência" -, como o próprio nome sugere e como já anunciado na apresentação assinada por Bruno, reproduz cartas enviadas e recebidas enquanto Du Rap esteve encarcerado. Entre essas duas partes, há algo em torno de vinte fotografias. São de André na Casa de Detenção, fora dela (em Suzano, onde morava, ou na Galeria 24 de maio), de amigos, de "resgatados pelo rap". Chama atenção que em apenas duas delas André esteja só: na primeira, em que está no pátio do Pavilhão 8 do Carandiru, e em uma das últimas, quando aparece como se estivesse apresentando o lugar onde vivia. Nas demais, em que se posta ao lado dos seus, prevalece o sentido de pertencimento a um grupo, ou talvez ao que Maria Rita Kehl chamou de fratria ${ }^{7}$ ao analisar a força do rap na periferia paulistana, presente também no texto - na dedicatória, nas histórias, em "Aliados".

\footnotetext{
${ }^{7}$ Ver "A fratria órfã", op. cit.
} 


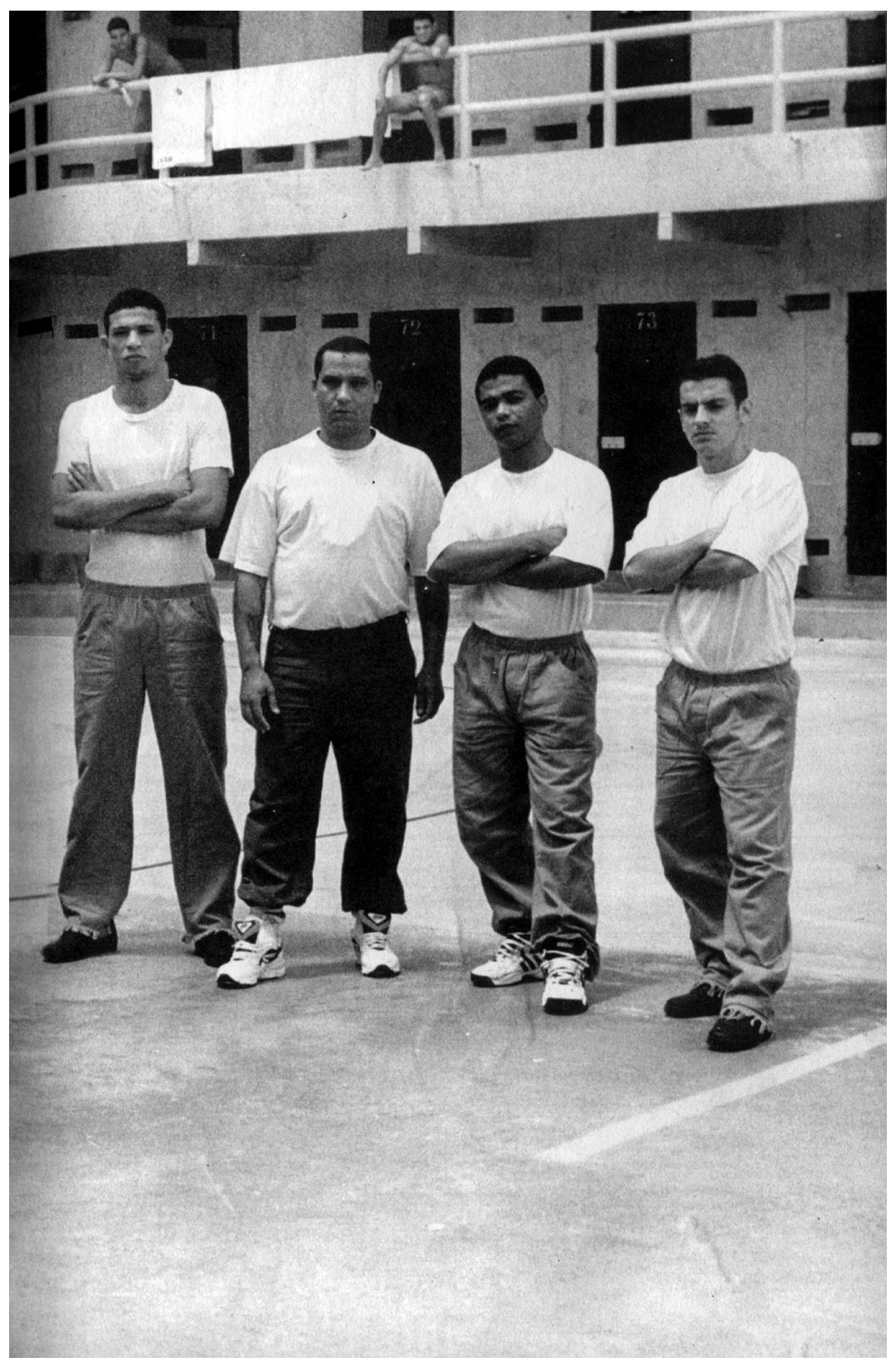




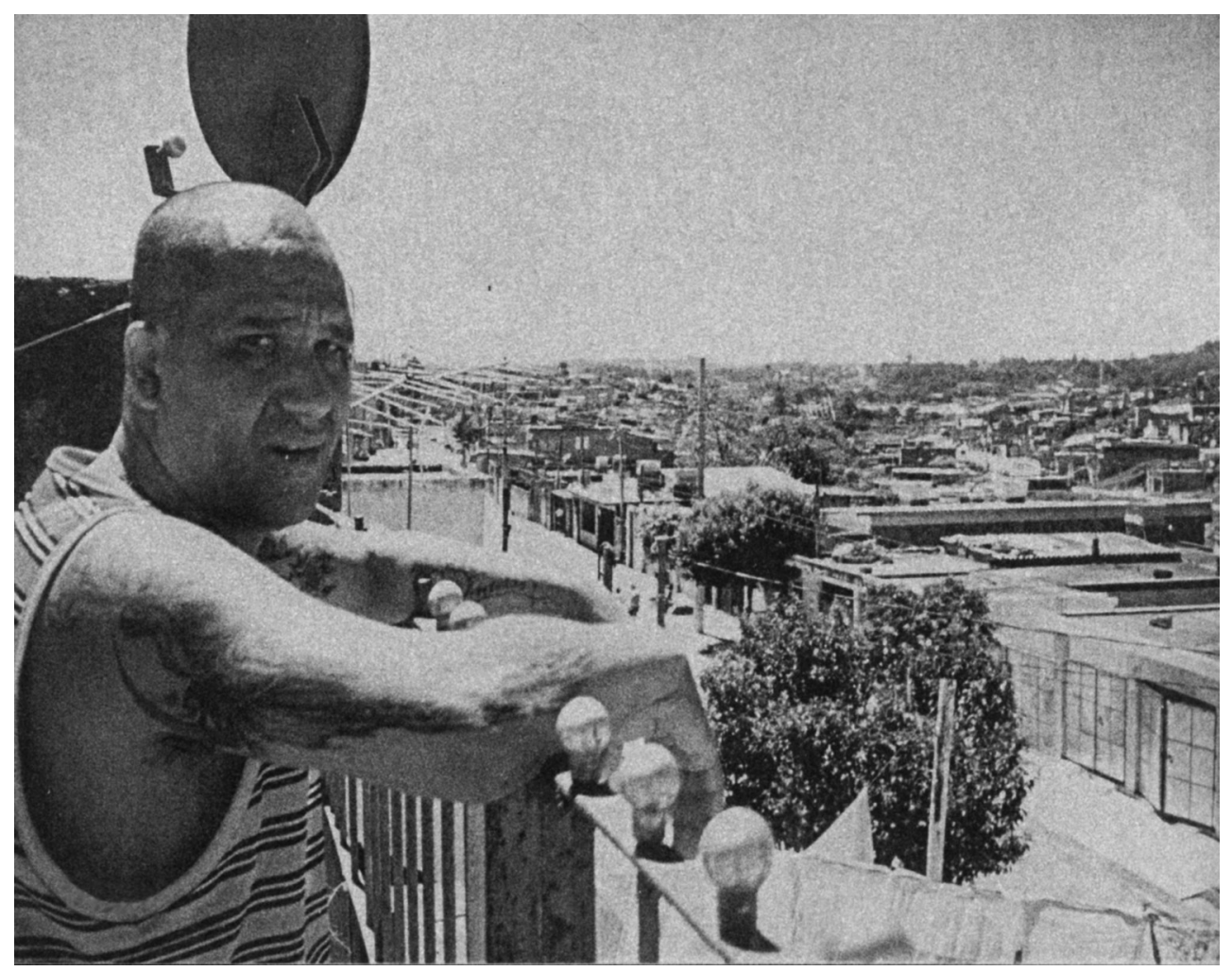

Em “Aliados", amigos de André - os "aliados", no dialeto da periferia e da cadeia dão seu depoimento. Em alguns, o teor consiste na transformação de cada um dos depoentes, de como o rap ou, de modo geral, o hip-hop foram armas fundamentais para tirá-los do crime ou das drogas. Em outros depoimentos, há a palavra de membros de associações civis que relatam a convivência com André e sua capacidade de "recuperação". Há também o comentário de dois integrantes dos Racionais MC's, Edi Rock e KL Jay. Chama atenção o modo como os sustentáculos da vida prisional se fazem visíveis aqui, no espaço dedicado aos "manos": eles se fazem perceber no elogio aos valores presentes a um só tempo no discurso de André (solidariedade, lealdade, humildade) e na forma que o livro assume (dando espaço a outros que não apenas seus autores, seja pelas fotos, seja pelos depoimentos), como discutirei adiante. 


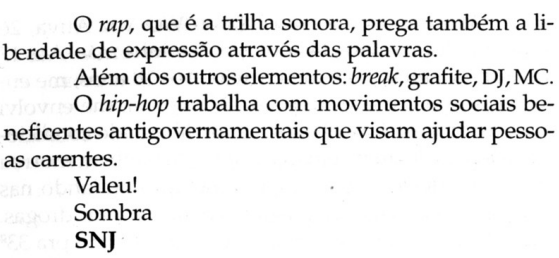

O rap, que é a trilha sonora, prega também a liberdade de expressão através das palavras.

Além dos outros elementos: break, grafite, DJ, MC

O hip-hop trabalha com movimentos sociais be-

neficentes antigovernamentais que visam ajudar pessoas carentes.

Valeu!

Sombra

SNJ

12 anos; os mesmos rostos, os mesmos olhares, o mesmo cheiro, a mesma roupa, as grades; a mesma raiva, inveja, esperança, tristeza; várias histórias... outro mundo.

Imagina só viver (ou melhor, sobreviver) +14.370 dias no meio disso tudo.

Agora acrescente +1 dia e tente imaginar o $2^{\circ}$ de outubro de 1992; cachorros, homens com ódio fardados e armados contra homens pelados com ódio, mas indefesos.

Inferno? Talvez pior..

Se coloca no lugar e no mínimo respeite, falô?

Só o amor nos salva..

KL Jay

Racionais MC's

Conheci o André du Rap quando consegui trazer para Ferraz de Vasconcelos, em parceria com a Central Sindical da Democracia Social e com recursos do FAT, alguns cursos profissionalizantes endereçados a desempregados. Ouvi atentamente o relato de André, a trajetória de sua vida, a experiência amarga dos anos de prisão, a recuperação e a reinserção na sociedade.
Sem nenhum constrangimento convidei-o para ministrar o curso de corte e costura e reforma de roupas na Vila São Paulo. Foi um sucesso. Revelou-se um ótimo instrutor.

Colaborou em alguns serviços, mostrou-se um voluntário na arte de ensinar.

Poucos dias depois, um novo André se revelava. Sentindo-se importante e capaz de ajudar na transformação da sociedade.

Ricardo de Oliveira Silva

Presidente do CCECAS

Muralha, guarita, robocop, fuzil

Funça, ferro, concreto,

bege, bege, bege

Sofrimento, mágoa, arrependimento,

Rancor, ódio, lágrimas, castigo,

Sol, futebol, sentimento, visita,

Amor, saudade, rebelião, esperança,

Revolta, vingança, rivalidade, inveja,

Crença, atitude, fé, covardia, maldade

"Sobrevivência"

Um mundo à parte dentro do nosso,

A poucos kms daqui, vai vendo.

A diferença da rua é q lá dentro

Você não tem pra onde correr,

A palavra é tudo,

Álibi, cúmplice, salvação ou sentença.

Aqui fora, ninguém dá a mínima

Pra isso, que $\mathrm{m}$..

Edi Rock

Racionais MC's

Depois do ensaio de Bruno Zeni ("Uma voz sobrevivente"), a seção "Sobre os autores" traz dados biográficos de André e Bruno.

O livro termina com os agradecimentos (outra constante nas narrativas do cárcere), em que cada um faz uma mais ou menos extensa lista de pessoas que não podem ser esquecidas. André agradece, em primeiro lugar, aos que morreram no massacre, bem como a outros amigos mortos. O seu rol de agradecimentos, bem maior que o de Bruno, revela a necessidade de lealdade aos companheiros mortos, bem como aos que estão a seu lado (como aqueles que dão seu depoimento na seção “Aliados"). É, como no livro de Jocenir, a expressão dos valores da cadeia: a necessidade de nomeação dos que lhe são ou foram solidários.

O livro se encerra com uma foto dos "autores", diz a legenda, sentados lado a lado na frente da casa de André. 


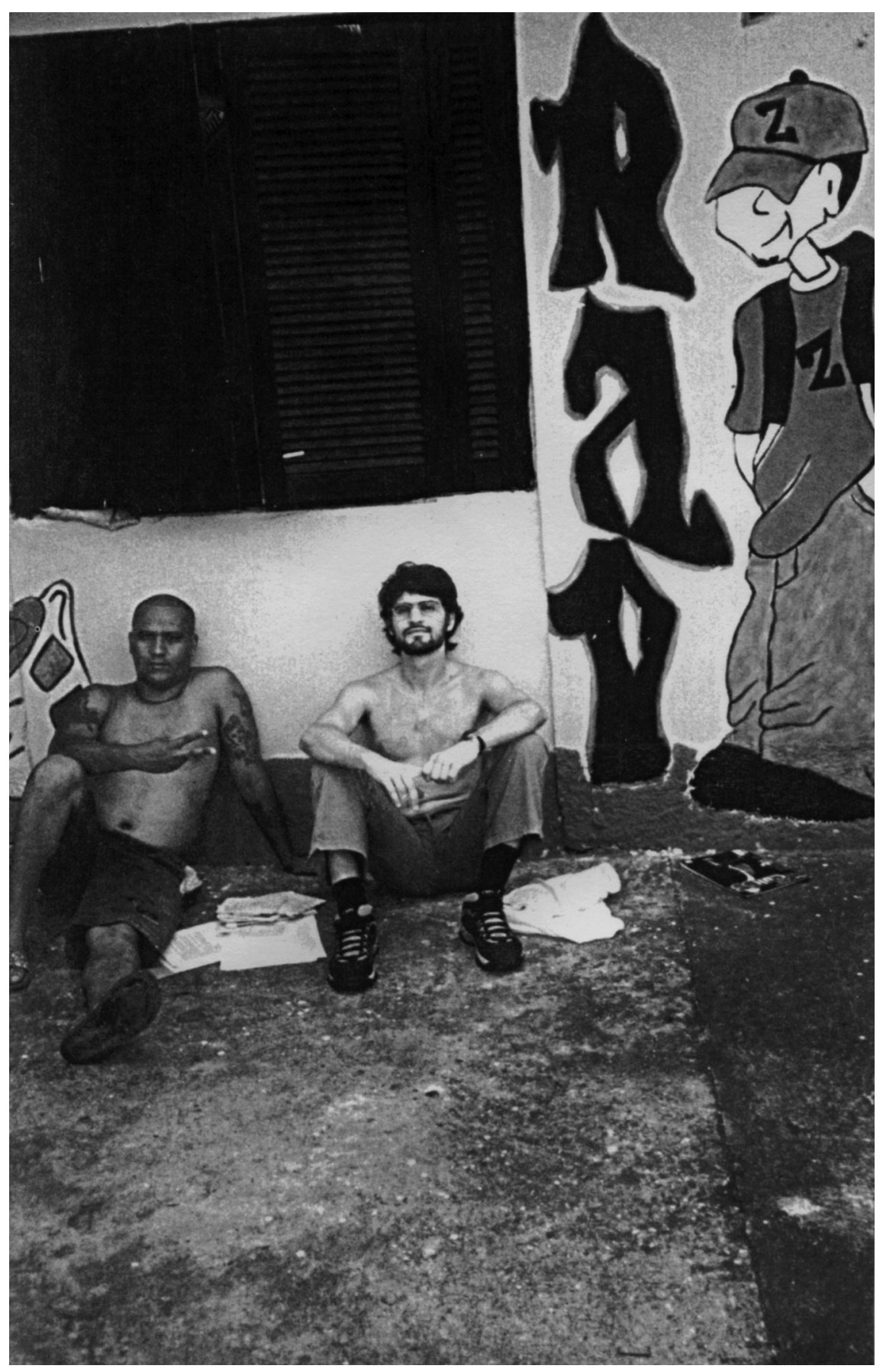

III.

A estrutura do "Free Style", grosso modo, é a seguinte: por meio de fragmentos (ou pequenas seções que recebem títulos, aos quais farei referência em alguns momentos), André apresenta-se, comenta a sua chegada à Casa de Detenção, os códigos de conduta, a escrita (também como algo singular), o reencontro com um antigo vizinho que tinha como 
ídolo, a rotina, a importância do esporte, a mudança de cela, o Massacre, o amor; faz apreciações sobre o sistema carcerário, conta dos castigos e das humilhações; revela a importância de ter sido apoiado pelos parentes e amigos enquanto esteve preso; reflete sobre o dom da palavra; condena o racismo e a exploração; elogia o hip-hop; e critica a mídia.

O que se percebe é que a base em que está construído o "Free Style" corresponde, nesse sentido, à do próprio livro, em que os temas acima mencionados constituem as partes de Sobrevivente André du Rap. Assim, produzir uma reflexão sobre o "improviso" de André du Rap é, de algum modo, também pensar como esse fragmento do mosaico que parece ser uma das marcas dessa literatura atua. ${ }^{8}$

No seu improviso, André, a exemplo do que já vinha fazendo, não perde de vista o fato de estar se dirigindo a um interlocutor que não compartilha os seus códigos - vide a explicação, aqui especialmente significativa, uma vez que não há a condução de Bruno, do que é “triagem”, “pago", "burra”, “pião", "barato já tá louco", "recorte”, “zoar”, "mula”. É como se André, apesar de a todo instante lembrar que sua mensagem se dirige aos jovens que flertam com a marginalidade, não se esquecesse de que é preciso contar essa história também àqueles que estão distantes dessa realidade (como Bruno) e que, portanto, não se reconhecem no seu “dialeto" (termo empregado por ele próprio) ${ }^{9}$.

No fragmento inicial, André se apresenta, como se, mais uma vez, fosse preciso singularizar-se. Essa oscilação entre o eu e o nós permeia o seu discurso: falando em nome do grupo, quando menciona os valores e os códigos de conduta da prisão, não consegue fugir à necessidade de mostrar as particularidades de sua trajetória. Ou seja, reconhece-se como membro do grupo, mas deseja preservar o que lhe é peculiar. "É a história de cada um, ninguém se livra dela", nas palavras do próprio André. Chama atenção que à necessidade de singularizar-se suceda o imperativo de revelar-se parte de uma coletividade (“nosso dialeto", repete às páginas 168 e 170).

\footnotetext{
${ }^{8}$ Vale a pena ressaltar o caráter coincidente dessa organização também com a dos demais livros escritos por presidiários. Todos eles, com maior ou menos insistência, fazem a denúncia ao sistema penitenciário, confirmam a importância dos entes próximos para atenuar a solidão, mostram-se fiéis aos valores da cadeia, reafirmam o sentido de missão de todos os que têm jeito com as letras, descrevem a rotina e os maus-tratos. ${ }^{9}$ A frase lapidar de Jocenir de que "um homem nunca é o mesmo depois da cadeia" refaz-se no livro de André na apropriação da fala da prisão como parâmetro ao qual não pode escapar: "Naquele momento, ali, o cara que era uma referência para mim e para várias rapaziadas aqui fora - não vou usar o termo molecada porque dentro do sistema moleque é homossexual (...)" (p. 171). Sinaliza com isso que, mesmo estando fora da cadeia, mantém-se fiel aos seus ditames, a sua linguagem.
} 
Na Casa de Detenção, André reencontra conhecidos:

"Tinha uns companheiros que moravam tudo junto, que eram tudo de Poá. Tem alguns até falecidos, é bom lembrar o nome deles: finado Durinho, finado Marquinhos - os dois falecidos. Tem o Cidoca, o Valdir, que hoje em dia tá em liberdade, o Cidoca também, e o Poinha, que também está em liberdade, moram aqui na região até hoje” (p. 168).

As notas de rodapé que acompanham o excerto contam, brevemente, como morreram esses seus aliados. A impressão que se tem é de que esse rememorar os mortos é uma das tarefas de que André se incumbiu ("é bom lembrar o nome deles"). A existência de tais notas é especialmente reveladora: se, por um lado, indica marcas de um discurso que escapa ao universo de André, uma vez que claramente acadêmico, ajuda a dotar Sobrevivente André du Rap das particularidades que caracterizam a sua hibridez formal.

O fragmento seguinte, "O dom das palavras", traz a informação de que o hábito da escrita é decorrente da prisão. A idéia da escrita como um “dom”, a que André alude com certa freqüência, é reveladora, uma vez que o termo remete à idéia de dádiva e privilégio. $\mathrm{E}$ como tal, deve ser devolvido de algum modo ${ }^{10}$, de preferência, revertido aos seus pares. Daí que a conduta, antes "viciosa”, uma vez redimida, deve ser exemplar.

Ainda nesse trecho, comenta a rotina, as cenas a que assistia. É especialmente digna de nota a lembrança do comentário de uma amiga, reproduzido por André: “É, você tem o dom com as palavras. Basta você exercer ele, e tudo que você quiser e tiver em mente você coloca num papel porque você pode reciclar isso e transformar em alguma coisa'. Mas eu não sabia no que transformar" (p. 169).

Aqui talvez apareça de modo mais efetivo como o processo de reindividuação de André tem relação estreita com mais essa singularidade - o que chama de dom da palavra. A idéia de que isso caminhe junto a uma transformação sugere a potência da palavra em um universo pouco letrado e a dificuldade mostrada por André, em um primeiro momento, em lidar com tamanho privilégio.

Considerando-se que os prisioneiros têm um código de conduta próprio, essencial para o bom funcionamento da vida enclausurada, é bastante coerente que um dos primeiros

\footnotetext{
${ }^{10}$ Ver, de Marcel Mauss, "Ensaio sobre a dádiva", op. cit.
} 
elementos do depoimento de André resvale para o confronto com esse etos, como se vê no fragmento "O ídolo", que parece ter marcado a trajetória do autor - talvez como um rito de passagem, uma espécie de perda da inocência.

O ídolo em questão, bom ladrão, conquistador, sujeito firme, havia, dentro da cadeia, virado "mulher" de outro encarcerado, em razão de tê-lo delatado. André, desavisado, tem de se haver com o "marido" do antigo ídolo, naquela que se mostrou, a julgar pelo depoimento, uma das situações mais tensas no convívio com os seus companheiros de prisão: "Naquele momento minha mente tá a milhão, porque tudo aquilo que meus companheiros falavam pra mim tava acontecendo. Conseqüentemente eu tava entrando em uma fita podre. Tava de chapéu atolado simplesmente por eu ter cumprimentado um amigo, esse meu amigo" (p. 172).

Embora André aparentasse dominar um certo conjunto de regras do grupo de presos, o episódio narrado parece ser aquele que lhe permite compreender de fato o seu significado. A sua estréia na vida prisional, se de início um pouco desastrada, mostra a rápida incorporação desse mesmo regimento, haja vista o silenciamento a respeito do desfecho do mesmo episódio. André revela que ainda traz esse código e esses valores ${ }^{11}$ : "Mediante a isso aconteceram vários fatores que nossos códigos de ética não consistem em estar contando porque é coisa lá de dentro, nossa" (p. 173, grifo meu).

André passa, então, a tratar da rotina (as saudades de casa, as orações antes de sair da cela, a hora de cozinhar) e, novamente, dos valores (respeito, humildade, lealdade, solidariedade e igualdade). Novamente, fala em nome do grupo. Revela que o início conturbado foi responsável pela assunção de postura mais cautelosa. Menciona esportes que praticava, o boxe e o futebol. E, ainda uma vez, assume o discurso coletivo: "A gente procurava se envolver, porque era um esporte, uma forma de você não ficar parado, a gente corria em volta do campo" (p. 174).

"Até que veio a rebelião [o Massacre] e eu passei por tudo aquilo que já foi falado" (p. 174, grifos meus). Esse trecho, que dá início à seção seguinte, contém aspectos de construção textual ${ }^{12}$ que merecem destaque. Em primeiro lugar, o "até" que interrompe a

\footnotetext{
${ }^{11}$ Esse traço é destacado pelo próprio Bruno Zeni em seu ensaio no fim do livro: "Como se percebe em seu depoimento, a experiência da prisão para André ainda é vivida como presente. Ele ainda fala em nome dos companheiros presos. Isso não se dá sem conflito e contradição: 'Nós temos nossos códigos de ética', diz ele, mesmo depois de ter deixado o sistema penitenciário" (p. 212).
} 
descrição da rotina na prisão. Em segundo lugar, o uso de "tudo aquilo", expressão que parece sinalizar a impossibilidade de nomeação do momento traumático.

Chama atenção a incapacidade de escapar à lembrança do Massacre, mas ao mesmo tempo a sua dificuldade em falar a respeito. André volta ao relato, ressaltando o quão presente era esse acontecimento quase dez anos mais tarde. Ele passa da descrição de uma cena ordinária - o habitual jogo de bola - ao evento deflagrador da "rebelião" - uma discussão, segundo ele - e, então, promove um corte, em que se percebe a entrada da polícia na cena.

"Eu me lembro como se fosse hoje", afirma, sem, em seguida, dizer do que se recorda. A descrição do Massacre já fora feita no início do livro (ver próximo item). Se em "Depoimento" havia a intervenção de Zeni e ainda assim era possível deparar com a sintaxe cortada, com a ausência de linearidade, agora, sem tal intermediação, o que se tem são fragmentos ainda mais estilhaçados. Novamente, André não pode deixar de nomear os companheiros - "Marcos. Fino, o apelido dele. E o finado Pico. Alexandre, o nome dele" (pp. 174-175).

Atente-se para o uso de "aquele" e "aquilo", repetidos à exaustão neste fragmento sobre o Massacre, que parece funcionar como um modo de deixar longe o já referido, como se o que foi dito já bastasse: "Chegamos lá [no segundo andar do Pavilhão] tava mó discussão, como eu já comentei, aquele tumulto todo. Aí foi onde que gerou tudo o que aconteceu"; "Aquilo ali foi um Holocausto. Eu olhava e não tinha noção do que estava acontecendo (...)"13 (p. 176, grifos meus).

A dificuldade de nomeação também se faz presente: "Aí teve um momento que cessou um pouco, no quinto andar" (idem). Outra vez, não se sabe o que cessou, mas a sugestão está feita.

André tece, então, uma série de considerações sobre a própria narrativa:

"E a gente corre até risco de vida por falar sobre isso, porque são poucos os que vieram falar dessa realidade. Eles ameaçam - o sistema é

\footnotetext{
${ }^{12} \mathrm{O}$ que autoriza uma análise de construção textual em um livro composto por depoimentos gravados é justamente a preocupação do entrevistador em preservar na transcrição os traços de oralidade: "Na edição do texto, procurei ser o mais fiel possível às particularidades da fala de André - mantive inclusive suas incongruências e incorreções (...)” (p. 9).

${ }^{13}$ Retomo a descrição e a análise dessa situação no item IV.
} 
covarde -, mas é a necessidade de alguém falar a verdade. Tem um companheiro, que é o Jocenir, que escreveu Diário de um detento. $\mathrm{O}$ doutor Drauzio Varela deu o maior apoio pra nós, escreveu Estação Carandiru. Pavilhão 9, com Hosmany Ramos, tem alguns depoimentos" (p. 177, grifo meu).

Aqui, é possível notar o uso de "isso", talvez mais um traço da dificuldade de nomeação, bem como a eleição de um "inimigo" ("eles", "o sistema" - que pode sugerir um discurso não raro de engajamento) e a necessidade de dizer o nome de quem já contou essa história (Jocenir, Drauzio, Hosmany), de quem teve a coragem (qualidade inequívoca entre os presos) de fazê-lo.

O senso de missão evidencia-se com a preocupação de que o Massacre não se repita (perceba-se a presença do "eles"): "Esta história tem que ser contada e não esquecida, porque foi uma vergonha pro nosso país. É uma vergonha quando você vê várias vidas indo, e até hoje eles não tomaram providência de nada" (p. 177, grifo meu).

A oscilação entre o narrar da sua história e a de seus companheiros reaparece. Inicialmente, fala de si: "É uma coisa que ficou marcada e vai ficar marcada pro resto da minha vida. O importante é frisar que foi uma experiência de vida. Que aquilo ali, só Hitler mesmo” (p. 178). Então, passa novamente à experiência coletiva: “(...) foi um Holocausto, um massacre, uma invasão, uma covardia, porque nós não estávamos armados, não existia nenhuma arma de fogo lá dentro" (p. 178). André mobiliza o conhecimento de momentos de barbárie, na expectativa de compartilhá-lo com o leitor, para tentar se fazer compreender. Há, evidentemente, a necessidade de estabelecer uma interlocução com aqueles que não viveram experiência semelhante, aqueles de quem quer se distanciar quando os nomeia de "sistema" ou "eles", querendo singularizar a si e ao seu grupo -, mas também de quem busca reconhecimento e compreensão - nos momentos em que "traduz" as gírias da prisão ou em que, como no trecho acima, procura aproximar o seu relato do Holocausto. Tal preocupação percorre o livro todo.

A tensão existente entre a vítima do trauma e o criminoso que se redimiu, sendo então capaz de aconselhar os mais jovens, aparece com bastante ênfase nesta sentença: "Então, passado isso tudo, hoje eu tenho essa reflexão" (p. 178). O emprego de "isso" o 
mantém distante do fato, mas a idéia de que, em função do vivido, é portador de experiência aproxima-o da situação traumática. ${ }^{14}$

Em "Caminhos entrelaçados", retoma o fragmento "A saudade na direta", a respeito da ex-namorada Eliana. Nota-se que a palavra é proferida em nome do grupo, salientando a existência de um objetivo em sua escrita: "Então, o meu objetivo, o nosso objetivo é mostrar o valor que tem uma companheira lá dentro, o valor que tem a família, porque a Eliana, ela me aceitou do jeito que eu era, reestruturou a minha vida, e toda companheira que aceita um companheiro que está lá dentro é uma guerreira” (p. 182).

A sua trajetória, as suas necessidades são também as dos companheiros de prisão, o que se percebe neste excerto em que ele parte da experiência individual para chegar a uma situação coletiva: "Ela [Eliana] me apoiou nos momentos mais difíceis, como cada companheira que apóia seus maridos lá dentro" (p. 182).

Há um senso de missão próprio de quem passou por experiências singulares, sobreviveu a elas, e é, portanto, capaz de enunciar uma palavra que sirva de conselho aos que não dispõem da mesma sorte. $\mathrm{O}$ fato de ser um sobrevivente do Massacre aparece-lhe como um sinal de eleição divina, e não é possível ignorá-lo: "Eu sei que Deus me deu um dom. Seja de compor, compor poema, poesia, letra de rap, seja de costurar, de conversar com as pessoas. Deus me deu um dom, e eu tenho que explorar ele. Então é isso que eu passo pros adolescentes, pras pessoas, quando eu vou num show, num evento" (p. 184).

No fragmento subseqüente, percebe-se que atrela a condição de sobrevivente ao discurso militante, proferido em nome da coletividade: "Então, quando a gente fala da consciência negra, é porque nós hoje, negros, ocupamos um lugar muito pequeno perante a nossa sociedade" (pp. 184-185).

O elogio ao hip-hop faz parte desse sentimento de grupo e recupera a premência de narrar a realidade a ser contada: "O movimento hip-hop faz a revolução através das palavras. É o jogo das palavras, é você pegar os conteúdos e transformar num ritmo, numa

\footnotetext{
${ }^{14}$ Márcio Seligmann-Silva notou que, nas obras produzidas no cárcere, "reencontramos (...) toda a metaforologia ligada à memória e ao esquecimento. A memória traumática e encriptada é revelada como uma modalidade de apresentação do esquecimento, do censurado e recalcado, que agora vem à tona nessas obras e reivindica o seu direito à voz. Inúmeras vezes lemos sobre prisioneiros 'aprisionados' em suas recordações, em flash back, das torturas que sofreram ou dos assassinatos a sangue frio a que assistiram dentro da prisão. Essas marcas, se por um lado são terríveis na sua presença constante e massacrante - que leva paradoxalmente à escritura como estratégia de arquivamento para esquecer -, por outro lado, são consideradas também como provas do ocorrido" (Márcio Seligmann-Silva, op.cit., pp. 40-41).
} 
poesia, numa realidade. (...) Porque a gente fala a verdade doa a quem doer, e a gente fala a nossa realidade" (p. 185). Na crítica que faz à mídia, encontra-se novamente o emprego de “eles" sinalizando o outro: "Por que a gente não está na mídia, por que a gente não estoura, não tem um canal aberto pro hip-hop? Porque eles não querem ver essa realidade” (p. 185).

Ainda aqui, a necessidade de evidenciar a experiência compartilhada: "Como eu, tem milhares de sobreviventes, mas todos eles sofrem represálias, como eu sofro também” (p. 185). A condição de sobrevivente, tantas vezes evocada por André, remete inicialmente, como o próprio título do livro deixa entrever, ao Massacre de 1992, mas André é também um sobrevivente da periferia, no que mais uma vez seu discurso se coaduna ao do rap: “Aqui quem fala é mais um sobrevivente” (Racionais MC's).

Em "Free Style", se a impossibilidade de dar conta da experiência se faz presente (o que é característico das vítimas de trauma), há outro aspecto que fica à espreita desse e que ajuda a singularizar a escrita prisional: a exemplaridade do relato. É preciso que essa escrita traga as marcas da humildade de modo a admitir os erros pregressos de seu autor, mas ela deve ser igualmente resistente ao discurso produzido pelo que André chama de "sistema". Esse enfrentamento é, também ele, exemplar dos valores coletivos ali professados responsabilidade, honra, coragem, além da já aludida humildade.

IV.

“(...) eram terríveis lances, obscuros para todo o sempre. (...) o horror de um quadro onde a realidade tangível de uma trincheira de mortos, argamassada de sangue e esvurmando pus, vencia todos os exageros da idealização mais ousada."1

A narrativa do Massacre, que não por acaso abre o livro, inscreve-se muito provavelmente entre as mais terríveis cenas da literatura brasileira. Faz lembrar a descrição abjeta dos destroços de Canudos, na aguda escrita de Euclides da Cunha, que tomo de empréstimo para a epígrafe.

O relato de André começa assim: "No dia dois de outubro, meu aniversário, abriu a tranca como de rotina" (p. 17).

\footnotetext{
${ }^{1}$ Euclides da Cunha, Os sertões, p. 778.
} 
Logo de início informa a data (apenas em parte, pois não situa o ano), mas não o espaço. Presume-se, no entanto, que ele, o sujeito que narra, estivesse trancafiado e aquele não fosse seu primeiro dia enclausurado ("abriu a tranca", "como de rotina"). Alguns dados não inteiramente esclarecidos aqui são esperados como de conhecimento prévio do leitor, como a existência do Massacre do Carandiru (e, em segunda instância, a sua data, 2 de outubro de 1992, o que preencheria a lacuna do ano não informado). Tendo-se a compreensão desejada e pressuposta (para a qual o título da seção igualmente contribui), o relato ganha ainda maior dramaticidade porque, de chofre, somos informados de que o dia do Massacre é também o dia do aniversário de André.

Apenas na frase seguinte se sabe quem "abriu a tranca" - André explica: "o funcionário veio e abriu". Para fazer compreender a rotina do presídio, Bruno lança mão de uma nota de rodapé, o que, como já insinuei, parece ser indício de incorporação de discurso científico, que precisa esclarecer e, no limite, comprovar. O teor explicativo da nota, a respeito das atividades desenvolvidas pelos presos, é suavizado pela ressalva de que foi André quem sentiu necessidade da explicação ("como lembrou André durante a revisão do depoimento", p. 17).

No desenrolar de seu testemunho, relata um fato ocorrido na véspera, ao qual parece atribuir o início da confusão entre os presos: "O dia anterior também tinha sido normal, só tava aquele zunzunzum devido a terem descoberto que o cara que morava com o Barba era moleque. Na linguagem da cadeia moleque quer dizer homossexual" (p. 17). "Na linguagem da cadeia" sinaliza a um só tempo a existência de um interlocutor "externo", não conhecedor do modo de falar da prisão, e de uma "linguagem" da prisão, que, assim como as atitudes implicadas, decorre da vida compartilhada naquele ambiente. Note-se ainda o uso do sinônimo culto para "moleque" - "homossexual" -, reconhecendo não só esse registro, como a conduta esperada pelo mundo dos homens livres, qual seja, a de respeito aos homossexuais, quando evita termos que possam assumir sentido pejorativo.

Logo a seguir, ocorre a explicitação do modo como se resolvem os conflitos na cadeia: primeiro o "debate" (em que se destaque o uso da palavra como primeira instância), depois, não resolvida a situação, pode-se partir para a agressão $^{2}$, com direito a

${ }^{2} \mathrm{O}$ que parece ser uma espécie de reprodução dos mecanismos judiciários (testemunho, veredicto, punição) aparece na narrativa de André como modo predominante de regulação dos conflitos entre os presos: "Quando tem uma confusão todo mundo quer ver, saber se é um irmão da quebrada, um companheiro. Pra tentar trocar uma idéia antes, fazer um debate, saber quem tá certo, quem tá errado" (p. 18). Esse modo de 
desdobramentos (quem fica desmoralizado precisa reverter aquela desvantagem momentânea para não fazê-la perpetuar-se). Na história de André, Coelho (o preso responsável pela descoberta de que o "moleque do Barba" era estuprador) e Barba primeiro tentam "trocar idéia" para resolver a situação. Depois discutem e partem para a briga. Como Coelho "levou a pior", viu-se obrigado a, conforme as regras do cárcere, reagir: "aquilo não podia ter acontecido, ele ia ficar desonrado dentro do presídio" (p. 18).

Ao comentar o episódio entre Barba e Coelho, Du Rap afirma, em um primeiro momento, que "foi negligência dos funcionários", como a reclamar uma ação eficaz do Estado capaz de conter a confusão que levaria à barbárie; em um segundo momento, parece querer reafirmar o etos prisional, indicando que aquela era uma questão a ser resolvida internamente e que, portanto, prescindiria da interferência dos carcereiros:

"Não existia [naquele momento] confronto entre os presos. Houve aquele do Barba com o Coelho e acabou. Os funcionários... Foi negligência dos funcionários. As pessoas que são responsáveis pela segurança, na hora que o pavio queima, na hora que a bomba explode, deixam você a pé, deixam você sozinho. (...) Os funcionários quiseram intervir, nós não deixamos. Treta de ladrão é treta de ladrão. É preso contra preso e já era. Acho que todo mundo sabe disso. As regras do presídio são essas, polícia pra um lado e preso pro outro. É o respeito" (pp. 18-19).

A interdição aos funcionários integra a separação existente entre as partes - desse reconhecimento derivam o respeito e bom convívio, em uma subversão clara do papel dos carcereiros, o de proteger os presos e zelar pelo bom funcionamento do presídio - função reclamada momentos antes por André. A ambigüidade desse trecho revela, por um lado, a expectativa de um dever-ser do mundo dos homens livres, em que funcionários de presídio comportam-se de modo a evitar a selvageria, por outro lado, ao perceber a impossibilidade de efetivação de um comportamento já visto como impraticável, André reafirma o modo de

conduzir as desavenças no presídio já havia surgido em Diário de um detento, notadamente no episódio em que Márcio, irmão de Jocenir, chega à prisão sob ameaça de outros presos (ver Capítulo 1). 
regulação dos próprios presos, na obediência à lei da prisão (“As regras do presídio são essas").

Pouco adiante, André comenta: "Todo mundo sabe que dentro da cadeia a gente tem que se defender contra a opressão. $O$ preso não vai ficar ali esperando ser massacrado" (p. 19). A aniquilação é percebida por André como uma possibilidade real, mesmo se sob a tutela do Estado - visto por ele como "opressão", em uma atualização do uso feito anteriormente de "eles" ou "sistema".

Os valores sustentados se fizeram valer quando, suspeitando da iminente invasão, os presos começaram a se proteger: "Todo mundo procurou ficar próximo - 'Cadê fulano, cadê beltrano?', todo mundo se procurando. Um preocupado com a segurança do outro, dos companheiros da quebrada, seu irmão, seu cunhado, primo, parceiro - se acontecer alguma coisa a gente tá todo mundo junto" (p. 19). Aqui, além da preocupação com o grupo, a tentativa de amparar os mais próximos. São vizinhos, parentes, parceiros, o que não pode deixar de ser percebido como um indício da sordidez do perfil penitenciário brasileiro, em que as pessoas se reencontram na cadeia, seja porque vêm de uma mesma família, seja porque moram em um mesmo bairro e, claro, muitas vezes, na cumplicidade da contravenção.

À medida que avança a narrativa do horror, a presentificação da situação-limite fazse entrever, assim como a necessidade de interlocução, solicitando ao que o escuta que "imagine" a cena inimaginável: "Você imagine mais de dois mil companheiros presos em situação de pânico. Tentando se defender, escapar da morte. Você escuta um tiro, o sentimento é de pânico" (p. 19).

Ao relatar a proximidade da morte, diz: "Naquele momento você faz uma retrospectiva da sua vida" (p. 20) - perceba-se que ele não diz "naquele momento eu fiz". André mostra a incapacidade de fazer "passar" o evento traumático, ao mesmo tempo em que tenta aproximar o interlocutor de fora do sentimento da catástrofe à espreita ("você").

É o início da invasão. Note-se a recorrência do emprego do "você", a necessidade de documentar (ao enumerar as celas em que se deram os eventos), a repetição de "morrer" (em que se destaque "gente morrendo", a sinalizar que não eram bichos) e a condição aviltada em que isso se dava (escondendo-se, debaixo da cama, fora de sua cela) ${ }^{3}$ :

\footnotetext{
${ }^{3}$ Em “Uma voz sobrevivente”, Bruno Zeni comenta essa passagem.
} 
"Na hora do tumulto, qualquer buraco mais próximo você tá entrando a maioria dos companheiros que morreram não estava na própria cela. Vi vários companheiros morrendo do meu lado. Gente morrendo. No terceiro andar, morreu muita gente dentro de uma mesma cela. Do 84-E até o 78-E morreram todos e a maioria nem era daquelas celas. Eram todos amigos que estavam só se escondendo. Morreram debaixo das camas, dentro dos banheiros, se escondendo. Tem companheiro que tava de roupa, morreram de roupa, rendidos, antes da polícia mandar todo mundo ficar nu" (p. 21).

Em seguida, a dificuldade de ordenar cronologicamente o relato, a percepção de que estar vivo era um "milagre", o horror de ter se escondido entre cadáveres, companheiros brutalmente assassinados na sua frente, e as repetições da mesma cena:

"Teve um momento que eu apaguei ali no chão, embaixo dos cadáveres. Foi um milagre o que aconteceu. Tinham vários companheiros mortos e eu fiquei ali embaixo dos corpos. A polícia atirava pelos guichês das celas. Eles colocavam o cano da metralhadora nos guichês e disparavam. $\mathrm{Eu}$, encolhido numa cela, escutando tiro pra tudo quanto era lado. A gente escutando ${ }^{4}$. É metralhadora? É fuzil? Não parava, aquele barulho. Chegavam no guichê, a janelinha da porta da cela, e metralhavam. O barulho aumentou até a nossa porta. Um cano apareceu no guichê. Eu vi quatro companheiros caírem do meu lado e me joguei também” (p. 21).

A categoria "sobrevivente", à qual André alude com freqüência, presente inclusive no título do livro, confunde-se com a presença de Deus:

"Nisso teve um companheiro que praticamente salvou a minha vida. Sou grato a ele. Ele também é sobrevivente. Hoje ele é pastor. Essa baionetada que eu tomei no meio da testa, a primeira foi nele, no

\footnotetext{
${ }^{4} \mathrm{O}$ embaçamento sinestésico dos sentidos - ele olha e escuta - também se faz notar no relato: "Eu olhei para trás e só ouvi gritos de horror, gemidos. Tropeçava em cadáveres, levantava” (p. 22).
} 
corredor. Ele me encobriu e acertaram o olho dele. Ele já tinha problema em um olho e acertaram o outro olho dele, ficou cego do outro olho. Teve outro companheiro que era crente, saiu com a Bíblia na mão, deram tiro em cima dele, mas ele conseguiu escapar” (p. 22).

A provação, a cegueira que leva, paradoxalmente, ao encontro da luz divina são motivos constantes no relato de André e aludem ao texto bíblico, como se o enfrentamento da morte tivesse sido tal que fizesse André acreditar que ali sua sobrevivência fosse um atestado da existência de Deus. Daí inclusive o acento na atitude sacrílega dos policiais, que nem sequer respeitaram a Bíblia.

Em sua narrativa dos "terríveis lances, obscuros para todo o sempre", André se vê compelido a justificar algumas atitudes que tomou ("Foi a única alternativa"), como quem explica que apenas se animalizando (ao jogar-se no meio dos corpos dos companheiros assassinados) ele teria alguma chance de sobreviver: "Do terceiro pro segundo andar, a cena era horrorizante: aquele monte de gente caída, e você ali em pânico. No segundo andar, numa distração deles, a gente se jogou no meio dos $\operatorname{corpos}^{5}$ que estavam ali no corredor. Foi a única alternativa" (p. 23).

Novamente, percebe-se a necessidade de fazer ver ao interlocutor-de-fora a covardia, ao mesmo tempo em que duvida da capacidade de apreender a cena. A humilhação sofrida é tal que André, em novo baralhamento dos sentidos, diz não sentir frio, apesar de nu e da temperatura hostil, mas apenas querer esquecer a dor (que nem sequer afirma sentir):

"Você imagina? Os caras encapuzados e você indefeso, nu como veio ao mundo. Nós só fomos ver o rosto de alguns policiais de noite,

\footnotetext{
${ }^{5} \mathrm{O}$ quadro formado pelas imagens de cadáver, deformação, sangue, urina e fezes lembra, como já sugeri, o final de Os sertões. Só que agora narrado por quem sobreviveu ao massacre: "Tô ali, deitado, vários companheiros sangrando do meu lado, urinando, cheiro de fezes... Olhava pro lado e via companheiros rasgados de metralhadora, cara estrebuchando, braços tremendo em cima de mim. Eu estava em estado de choque" (p. 24); "Vi cara ser mutilado por cachorro na minha frente" (idem); "Começamos a lavar o pavilhão, puxando com rodo aquele monte de sangue. Pedaço de carne, pedaço de companheiro seu, pedaço de ser humano ali no meio da água misturada com sangue, sangue de vários homens" (p. 25). Francisco Foot Hardman, em seu ensaio "Tróia de Taipa: Canudos e os irracionais", explora a presença fantasmagórica do episódio de Canudos na história recente (mas não só) do país: "quantas Canudos são massacradas por ano nas favelas, delegacias, ruas e ermos desse Brasil?" ("Tróia de Taipa: Canudos e os irracionais", p. 129).
} 
quando já tava todo mundo rendido e eles começaram a entrar nos barracos $^{6}$ e quebrar televisão, quebrar rádio. Tava chovendo, a gente sentado no pátio, nu, frio. Mas eu nem sentia frio, eu só queria esquecer a dor" (p. 25).

A impossibilidade de esquecimento vem junto à lembrança de que tudo aconteceu na data de seu aniversário, data de seu (re)nascimento. Como aparece em "Free Style", o emprego de "isso" parece sinalizar a impossibilidade de nomear o que houve. Prevalece o sentimento de impotência e de revolta:

"Ninguém nunca vai tirar isso da minha mente. Tem companheiros que ficaram traumatizados, não gostam nem de lembrar. Eu mesmo, até hoje eu tenho pesadelos com isso. Às vezes eu me vejo naquele dia, lembro de como começou, um amigo de cela me falando, alguém dizendo:

— Ô, André, hoje é seu aniversário, mano! Segunda-feira eu vou embora, vou mandar um presente pra você aí, de lá de fora.

Esse amigo morreu na minha frente, tomou mais de 18 tiros de metralhadora na minha frente. Vi o cara caído e não podia fazer nada. (...)

O que aconteceu no Carandiru foi uma crueldade. Nenhum ser humano merece aquilo. Estar num sistema qualificado como o pior do mundo e sair de lá morto... É um pedaço da minha vida e eu tenho que estar aberto para falar disso. Foi um fato que aconteceu e está escrito na história do país. Acho que Deus tinha um propósito na minha vida, um propósito em me tirar daquele lugar, como na vida de muitos companheiros que também sobreviveram" (pp. 25-27).

Desse último excerto, gostaria de reter alguns pontos:

André constantemente retoma a narrativa do companheiro que seria solto poucos dias depois, mas que foi morto no Massacre. Percebe-se a dificuldade em lidar com a sua

\footnotetext{
${ }^{6} \mathrm{O}$ emprego de "barraco" para designar a cela sugere que a "linguagem da cadeia" (nos termos do próprio André) incorpore a visão estereotipada que se atribui à prisão como uma grande favela (aqui entendida como habitação precária reservada ao que o senso comum reconhece como escória da sociedade ou como "os irracionais" - ver F. F. Hardman, op. cit.).
} 
sobrevivência e a morte do rapaz, o que contribui para a necessidade de narrar repetidas vezes o episódio, em homenagem ao companheiro assassinado.

Estar no "sistema", como André se refere ao sistema penitenciário, mais precisamente, o paulista, visto como "o pior do mundo", é em si um castigo. A tentativa de aniquilá-los é a duplicação do castigo ("e sair de lá morto"). A idéia é a de um sofrimento dobrado: ele e os outros presos já viviam como animais e nem a dignidade mínima de sobrevivência lhes foi garantida.

André, nesse fragmento, parece responder ao discurso que tende a condená-los porque presos, chamando a atenção para o fato de que eram, antes de tudo, seres humanos: "nenhum ser humano merece aquilo".

Outra vez, ele se mostra imbuído de uma missão ("eu tenho que estar aberto para falar disso", grifo meu). Aproveita para inscrever o fato como real e como pertencente à história do país - e nesse sentido nos torna cúmplices do que houve.

Mais uma vez, Du Rap celebra a presença de Deus (várias vezes evocado), a realização de um milagre, tanto com ele (singulariza-se: é a sua história), como com outros (os que sobreviveram - aqui, nota-se movimento de ampliação do discurso). A necessidade é de narrar a sua história, mas também o que houve com os outros. A idéia da provação divina refaz-se aqui, como se, tendo sobrevivido, precisasse louvar a existência de Deus.

Curiosamente, essa preocupação em contar a história também dos outros é o que parece aproximar Bruno e André em seus - chamemos assim - "projetos de narrar": André precisa fazê-lo na condição de sobrevivente; Bruno precisa fazê-lo porque se sente no dever de narrar o que ouviu, de "dar rosto" aos 111 mortos.

Jeanne-Marie Gagnebin, em artigo intitulado "Memória, história, testemunho", propôs que:

"uma ampliação do conceito de testemunha se torna necessária; a testemunha não seria somente aquele que viu com os próprios olhos (...). Testemunha também seria aquele que não vai embora, que consegue ouvir a narração insuportável do outro e que aceita que suas palavras revezem a história do outro: não por culpabilidade ou por compaixão, mas porque somente a transmissão simbólica, assumida apesar e por causa do sofrimento indizível, somente essa retomada 
reflexiva do passado pode nos ajudar a não repeti-lo infinitamente $(\ldots)^{\prime \prime}$.

Nesse sentido, talvez seja possível comungar da perspectiva de Gagnebin e alargar o sentido de testemunha a Zeni.

V.

"Uma voz sobrevivente" é o nome do ensaio, de autoria de Bruno Zeni, que fecha o livro. Como já salientei, Bruno, a julgar pelo prefácio, não parecia considerar seu texto final como parte integrante da matéria narrativa de Sobrevivente André du Rap. Tal exclusão precisa ser compreendida, parece-me, pelo que revela: em primeiro lugar, tentativa de preservar como matéria a história, as cartas, as fotos, os depoimentos de André e de seus amigos, sinalizando que, pesadas todas as possíveis escolhas suas, é André o autor do livro. Em segundo lugar, ao não incorporar o seu ensaio como parte do livro propriamente, Zeni fica autorizado a tecer comentários sobre ele (ainda mais quando se leva em conta que a autoria, assim vista, era de André e, portanto, era possível escrever sobre a história de André).

Interessam-me esses dois aspectos imbricados um ao outro: ao apartar o ensaio do livro, Bruno confere autoria a André e, afastando-se dela, pode escrever sobre o resultado obtido. Como fiz em relação às outras seções analisadas, passo à descrição do ensaio:

Logo de início, Zeni sugere que "experiência" e "presença" são vistas como fatores importantes de legitimação e dignificação do relato. Aproveita para apontar qual o objetivo do livro: "somar à história do massacre mais uma narrativa" (p. 199). Ora, já se percebe aqui o que será confirmado ao longo do texto: as filiações críticas de Bruno, que, na melhor tradição benjaminiana, preza a história feita de histórias, bem como valoriza a experiência.

A crítica à violência (a partir da Escola de Frankfurt) perpassa o ensaio, assim como o elogio do trabalho de memória, a percepção dos mecanismos de poder (a partir de Foucault) - Bruno mobiliza seu repertório crítico para interpretar a obra da qual é co-autor. Observem-se, por exemplo, os subtítulos conferidos a algumas das seções do ensaio, todos eles em clara incorporação de um discurso crítico que condenaria com toda a veemência o que houve naquele 2 de outubro de 1992, em São Paulo: "Dar rosto aos 111 e contar as

\footnotetext{
${ }^{7}$ Jeanne-Marie Gagnebin, op. cit., p. 93
} 
suas histórias", "Memória e evocação", "Testemunho e representação", "Os corpos dóceis".

Quando, por exemplo, comenta o cinismo dos agentes envolvidos na invasão ao presídio, ou quando trata da ação de entidades ligadas aos Direitos Humanos e do trabalho de artistas e escritores que criaram a partir do Massacre, Bruno parece revestido de preocupação política, sem descuidar de suas dimensões (necessariamente atreladas) sociológicas e estéticas. Um excerto em que comenta o comportamento do grupo de rap Racionais é bastante emblemático: "Eles se recusam, por exemplo, a participar de programas de auditório, atitude que certamente os preserva da massificação homogeneizante, que iguala tudo no simulacro de realidade da $T V$, tão bem executado no Brasil” (p. 201, grifos meus). À postura francamente política, junta-se o vocabulário de inspiração frankfurtiana e pós-estruturalista, o que se confirma no decorrer do texto, tanto no que toca à sugestão ${ }^{8}$, como de modo explícito ${ }^{9}$.

Tendo feito o trabalho de recuperação da sua memória do Massacre e do modo como se viu tocado por ele, Bruno conta como conheceu André e como nasceu o livro. Faz a análise de alguns aspectos da narrativa de Du Rap, como o tempo ("O tempo da ação é circular, não obedece linearmente ao desenrolar dos acontecimentos”, p. 207), o léxico (“'Horrível' é certamente pouco: talvez por isso André use a palavra 'horrorizante' - uma palavra deformada, assim como a situação vivida", p. 208) e a linguagem de modo geral (como quando comenta o uso do termo "cão" - "Vocês vão ver o que é o cão" - por parte dos policiais invasores: "É o real hipertrofiado, é a impossibilidade absoluta de abstração, a aniquilação da capacidade de figurar, fabular ou sonhar - a amortização da linguagem, sua redução ao que ela tem de mais cru: uma tautologia e uma literalidade sem brechas”, p. 208).

\footnotetext{
${ }^{8}$ Observe-se, por exemplo, esta passagem em que deixa clara a intenção de seu projeto inicial em dar nome aos que morreram: "O número 111, com todo o seu poder de ícone, se prestava então a uma dupla função: conferia uma violenta força de identidade ao episódio, fazendo do Massacre um emblema da nossa barbárie, mas também cristalizava a condição anônima daqueles que haviam sofrido a ação de extermínio. (...) as vítimas do Massacre tinham virado número" (p. 203).

${ }^{9}$ Exemplo disso é quando, tendo parafraseado o argumento de "O narrador", de Walter Benjamin, comenta: "A memória de André a respeito do Massacre me parece ser capaz de exercer essa função de nos aproximar a todos, tecendo na sua narrativa uma história que é sua, mas também daqueles que morreram" (p. 206).
} 
Zeni faz questão de compreender aquilo que venho chamando de etos prisional, quando, por exemplo, chama atenção para a preocupação de André com o fato de que vários companheiros tenham morrido "fora do xadrez".

Depois de listar outros assuntos narrados por Du Rap e que contribuiriam para mostrá-lo não como um "bandido", Bruno sentencia:

"A história de André antes e depois do Massacre dá concretude àquilo que julgo ser fundamental para compreender o absurdo daqueles posicionamentos (...) que defendem a violência policial contra a população carcerária: sua vida não se reduz à condição de presidiário ou de 'ladrão'; José André de Araújo, assim como todo e qualquer homem preso, não é um número nem uma besta" (p. 211).

Aqui, parece evidente que a narrativa de André também tem, para Bruno, a função de mostrá-lo sem o estigma do ex-presidiário, a que André faz referência diversas vezes daí talvez a escolha em publicar as suas cartas, as fotografias que o mostram à frente de vários projetos sociais na periferia de São Paulo, o testemunho dos aliados que confirmam que André é um sujeito digno.

Em seguida, Bruno atribui importância à condição de sobrevivente de André, que, como tal, precisa narrar para que os fatos não se repitam: "As lembranças de André du Rap também estão, de forma inequívoca, delineadas por sua função social exercida aqui e agora. A necessidade de contar a história do Massacre para que ela não se repita (...) vem de sua condição de sobrevivente" (p. 210). Nessa condição, aproxima-o, fazendo a mediação não estabelecida por André, da comparação com o Holocausto. Quando, por exemplo, comenta proximidades com a experiência-limite dos campos de concentração, faz ressalvas:

"Na fita em que gravou sozinho, (...) André compara o Massacre do Carandiru ao Holocausto e ao Vietnã. Ainda que as comparações pareçam desmedidas - e o recurso tentador de chamar o Massacre do Carandiru de 'O Holocausto brasileiro' seria diluir as particularidades de cada um dos genocídios, empobrecendo a ambos -, a comparação dá 
o que pensar, especialmente em relação à dificuldade em elaborar simbolicamente uma experiência traumática, ponto cervical de toda a literatura de testemunho do Holocausto e do debate crítico e ético que a envolve" (p. 212).

As citações que vêm como desdobramento da mediação feita são especialmente reveladoras e se coadunam ao arcabouço teórico delineado ao longo do ensaio - Zeni recupera os estudos feitos a partir dos testemunhos da Shoah e, em esforço analítico, tenta compreender em que medida são úteis para a narrativa de André. Essa sua busca aparece quando articula a linguagem de Paul Celan à "fala fraturada de André du Rap" (p. 214) e comenta que: “A opção pela manutenção das arestas da narrativa oral busca conservar as marcas do seu trauma, identificadas na forma do seu relato, e que corriam o risco de se diluir se procurássemos consertar ou reescrever o seu depoimento" (p. 214). Explicita aqui, portanto, os princípios críticos que nortearam suas escolhas no momento de dar forma ao $\operatorname{livro}^{10}$.

Chegando ao fim, reafirma seus propósitos: "Este livro se pretende uma peça de resistência, dentro de um sistema que tem por norma excluir e massacrar, para que nada de semelhante ao que se fez no Carandiru em 1992 volte a acontecer” (p. 218). A urgência em narrar para que nada parecido ao Massacre aconteça é formulada em termos muito próximos aos dos sobreviventes dos campos de extermínio da Segunda Guerra - o que não deve ser visto com espanto, uma vez que Bruno assume as referências teóricas que balizam seu ensaio, notadamente, mas não apenas, os filósofos frankfurtianos e pensadores do dever-de-memória pós-Holocausto ${ }^{11}$, aqueles que pesquisam formas de representação em tempos de catástrofe.

Valendo-se da contribuição de Michel Foucault (em seu estudo sobre as prisões francesas - Vigiar e punir) e de Roberto Schwarz (especialmente de sua tese sobre as

\footnotetext{
${ }^{10}$ Isso fica ainda mais evidente quando Bruno faz menção a um ensaio em que Jeanne-Marie Gagnebin, a partir das reflexões de T. Adorno e M. Horkheimer, escreve que: "a mancha do Holocausto impõe uma reflexão ética e moral que acompanha nossas criações estéticas” (p. 218).

${ }^{11}$ Observe-se, como exemplo, este fragmento de autoria de Shoshana Felman: "Aquilo em que consiste a violência do Holocausto - a própria essência do apagar e do aniquilar - não é tanto a morte em si, mas o fato ainda mais obsceno de que a própria morte não faz diferença, o fato de a morte ser radicalmente indiferente: todos são colocados num mesmo plano, pessoas morrem como números, não como nomes próprios. Em oposição a esse nivelamento, testemunhar é, precisamente, engajar-se no processo de reencontrar seu nome próprio, sua assinatura" ("Educação e crise, ou as vicissitudes do ensinar", pp. 64-65).
} 
“idéias fora de lugar" - Ao vencedor as batatas), sugere, no que parece ser o ponto central de seu ensaio, que, se na França as penas pararam de incidir sobre os corpos, no Brasil, esse sistema persiste: "as penas que incidem sobre os corpos da população carcerária [prémoderna, segundo Foucault] continuam atuando no ventre do inchado e abarrotado sistema carcerário brasileiro" (p. 215), o que se comprovaria, segundo a percepção de Bruno, na manutenção da tortura nas prisões do país.

A minha insistência no "rastreamento" da filiação crítica de Bruno Zeni tem certa razão de ser. No início deste capítulo, sugeri que a forma final do livro talvez fosse responsabilidade de Bruno, em um difuso compartilhamento de autoria com André. Feito o percurso, expostos os procedimentos que Zeni assume como escolhas suas, a questão poderia ser dada como encerrada. Mas eis que se torna mais complexa: ao atribuir a autoria a André, o que faz tanto textualmente como ao eximir seu ensaio final da condição de parte da matéria que compõe o livro, Bruno torna-se capaz, mesmo se momentaneamente, de olhar para Sobrevivente André du Rap como se não lhe pertencesse, embora evidentemente seja também seu. Nesse momento, analisa o livro à luz dos mesmos autores que contribuíram para a forma final de Sobrevivente André du Rap. As referências procedem: tratam da impossibilidade de narrar causada pelo trauma e a urgência narrativa daí advinda, para render homenagem aos que morreram e para que o que houve não se repita. Nesse sentido, o livro é, como disse Bruno, uma peça de resistência.

Interessa-me, no entanto, olhar para o que se desdobra daí: um livro que tanto interna quanto externamente aponta para uma dupla autoria. O que resulta desse encontro e se conforma em livro é igualmente a junção de duas experiências pessoais e sociais díspares. Se a história é a de André, a forma parece adequada aos valores professados por André, quais sejam, os valores da cadeia, que André toma como seus mesmo em liberdade. Assim, a forma corresponderia, como tenho sugerido, aos modos de sociabilidade do cárcere. Mas como entender a presença do jornalista e literato que, conhecedor das pesquisas sobre violência, trauma e memória, inequivocamente contribui para conformar o texto $^{12}$ da maneira que julga corresponder ao modo de ser de André?

\footnotetext{
12“"Eu fiz questão de colocar o massacre, que seria o clímax, primeiro; porque acho que é forte e é atual, mas também porque eu acho que é a condição, a identidade dele: ele se considera o sobrevivente" (Folha de $S$. Paulo, 09/09/02, op. cit.).
} 
De um lado, as necessidades, as marcas de oralidade, o senso de missão, as repetições, além das cartas, dos depoimentos e das fotos, tudo enfim que envolveria o etos da cadeia e também um certo modo de André ver o mundo. De outro, o desejo imperioso de Bruno de dar nome aos 111, de dar a sua contribuição para que o 2 de outubro de 1992 não se repita - o que é também a maneira como parece enxergar o mundo. São ambos, como se vê, desejos convergentes. O modo de formalizá-lo, por meio da narrativa da história de André, é igualmente um anseio comum. Como sugerido acima, Bruno é imbuído de um desejo político de narrar de modo a não negar a identidade de André, de modo a não estigmatizá-lo (ele troca $\operatorname{cartas}^{13}$, dá valor à escrita, tem relações amorosas, sofre), a contribuir para não perpetuar a imagem de "número ou besta" que parece envolver os presidiários. E para fazê-lo, mobiliza o que conhece, tal qual André quando escolhe as fotos, as cartas, os amigos que gostaria de ver publicados ou quando, no "Free Style", retoma episódios já narrados nos momentos de conversa gravada com Bruno, sinalizando o que deve permanecer na edição da sua história.

Se se considerar o livro com um todo, sem excluir os dois textos de Bruno (o que apresenta e o que encerra o volume), tampouco desprezar as notas de rodapé, ele se torna mais complexo, porque passa a permitir a percepção da formalização de algumas impossibilidades objetivas do quadro social brasileiro.

Sobrevivente André du Rap, sendo a convergência de duas urgências narrativas de origem diversa, traz essa dualidade quando adota uma forma que é híbrida. O livro não é simplesmente uma transcrição das entrevistas (além do "Free Style", há as fotos, as cartas, os depoimentos), não é apenas uma autobiografia (a presença de Bruno é inequívoca), tampouco uma biografia (o que se poderia sugerir pela presença de Zeni, se ele falasse por André, o que não se confirma). É, sim, um livro escrito a quatro mãos em que se fazem notar as contribuições de cada um deles para dar forma à história de André.

Bruno responsabiliza-se pela edição, jornalista que é, e pelo ensaio, que deve levar em conta as particularidades das lembranças de quem viveu a possibilidade real do extermínio - e para tanto constrói estratégias formais de linguagem que mobilizam as

\footnotetext{
${ }^{13}$ Ainda na entrevista à Folha de S. Paulo, Bruno comenta sobre as cartas: "Essas cartas são o único lugar no livro em que tem, de fato, a escrita dele; o resto é a nossa conversa. E acho que elas, de um jeito um pouco desarrumado, com lacunas, conferem materialidade à história dele. São o registro do que ele sentia na época; o depoimento é a memória dele, com tudo o que ela tem de mais rico: a memória refaz o que aconteceu e deixa muita coisa de fora, não é? É inevitável” (Folha de S. Paulo, 09/09/02, op. cit.).
} 
pesquisas feitas com os sobreviventes da Shoah, bem como o que reconhece como a contribuição dada pela Teoria Crítica para o narrar após Auschwitz, revelando a sua filiação como estudioso da literatura. Procura fazê-lo de modo a não recusar a condição de sobrevivente de André nem a sua própria condição: esclarece o que julga ser necessário em notas de rodapé, um recurso do discurso acadêmico-científico, que não pertence ao ambiente da prisão. É claramente um modo de não se fazer notar - tal qual o pesquisador mas que acaba por revelá-lo como também autor daquele modo de narrar a história de André.

André, por sua vez, parece ter interesse no uso da nota de rodapé porque, assim como a presença de Bruno, ela contribui para atestar que o que ali está sendo narrado de fato aconteceu - as notas de rodapé afinal têm esta função: amparam o que acaba de ser escrito.

Resulta daí um livro ambivalente não apenas em sua adesão ao discurso externo e interno à cadeia (dimensão evidentemente presente), mas também na dupla autoria de sujeitos com trajetórias distintas e que trazem para a linguagem essas diferenças. Por um lado, desponta o discurso articulado, legitimado, acadêmico. Por outro, percebem-se as marcas de oralidade, a insuficiência vocabular - daí os neologismos - para dar conta do evento traumático, a sintaxe interrompida, a necessidade de transformar o livro para ser fiel aos ditames da cadeia, aos quais ainda se reporta. Ainda, essa escrita mostra-se leal aos que o ajudam ou ajudaram, dando-lhes rosto e palavra (nas fotos e nos depoimentos) - e nesse sentido aqui também André faz valer os valores da cadeia. O discurso de André atesta o seu pertencimento àquele ambiente, o que se percebe na ambígua relação que estabelece com o título-estigma de ex-presidiário, como também na inclusão das fotos, inclusive a da capa, em que ele está dentro do presídio, ou mesmo, logo no início do livro, na reprodução dos contatos fotográficos de seu rosto (cujas cicatrizes seriam rememoradas no texto como marcas da violência de que foi vítima).

Essa dupla autoria que revela suas condições de produção, sem mascarar os dois sujeitos que falam e de onde falam ${ }^{14}$, mas, ao contrário, apostando nas suas contradições como formadoras do livro, configura-se como traço de originalidade desse volume em

${ }^{14}$ A respeito do papel daquele que transcreve o testemunho latino-americano e seu estatuto problematizado pela teoria que a ele se dedica, ver o artigo "Este corpo, esta dor, esta fome", de João Camillo Penna, op. cit. 
relação aos demais. Ao mesmo tempo, a fotografia ao final (Du Rap e Zeni juntos) pode ser lida como uma aposta inusitada de que o senso de fratria que parece reger os valores de André é ali compartilhado com Bruno. No entanto, é preciso salientar que a vida prisional é tão coerciva que, mesmo com as intervenções de Bruno, há certas estruturas frasais de André que expõem o que aparece também nos outros livros aqui estudados, como procuro mostrar. 


\section{Capítulo 3 (ou "Sou o que resulta daí")}

I.

Memórias de um sobrevivente é o livro de estréia de Luiz Alberto Mendes. Depois desse, vieram Tesão e prazer: memórias eróticas de um prisioneiro (2004) e Às cegas (2005). Mendes é, sem dúvida, o mais bem-sucedido desse grupo de escritores egressos da prisão e é aquele cuja escrita mais repercutiu: autor de duas peças e de, segundo conta, 5 livros inéditos, sua escrita tem atraído a atenção da crítica acadêmica, que lhe dedicou artigos, dissertações e monografias. ${ }^{15}$ Assina, desde 2002, coluna na revista mensal Trip. Seu Memórias de um sobrevivente, de acordo com ele, vai virar filme ${ }^{16}$.

Encarcerado por cerca de trinta anos, é também, do grupo aqui analisado, o escritor com mais tempo de prisão. Seu contato com a literatura, segundo Sérgio Adorno, o "ponto de inflexão que torna o [seu] livro distinto dos demais" ${ }^{17}$, se deu na cadeia, em episódio narrado nas Memórias e por ele sempre evocado em entrevistas.

O "Professor", como era conhecido na Casa de Detenção, deve sua "descoberta" ao escritor Fernando Bonassi (autor do prefácio do livro), que, em 1999, ministrou oficinas de literatura e organizou um concurso literário do qual o conto "Cela-forte", de Mendes, foi o vencedor.

O lugar de destaque que ocupa não é, decerto, à toa. Seu primeiro livro, publicado pela prestigiosa editora Companhia das Letras (assim como o seria seu As cegas) ${ }^{18}$, já apontava para um domínio da escrita e das estruturas narrativas, visível nas suas quase 500 páginas.

Memórias de um sobrevivente, assim como Diário de um detento e Sobrevivente André $d u$ Rap, conta a história de Mendes enquanto esteve preso, mas, ao contrário do livro de Jocenir e de André du Rap, não se limita a isso, recua aos anos de infância, às primeiras

\footnotetext{
${ }^{15}$ Ver, especialmente, de Márcio Seligmann-Silva, "Novos escritos dos cárceres: uma análise de caso. Luiz Alberto Mendes, Memórias de um sobrevivente"; e, de Andrea Saad Hossne, "Autores na prisão, presidiários autores. Anotações preliminares à análise de Memórias de um sobrevivente"; bem como dissertação de Adauto Locatelli Taufer, Do factual ao ficcional: memória, história, ficção e autobiografia nas Memórias de um sobrevivente, de Luiz Alberto Mendes (UFRGS); e a monografia de Luciana Araújo Marques, De dentro: escritos da periferia e da prisão (Faculdade Cásper Líbero).

${ }^{16}$ Ver entrevista feita por Mauro Ventura com Mendes em 30/03/2008, na Revista O Globo.

${ }^{17}$ Sérgio Adorno, “A ciência da tortura", Jornal de resenhas, 12/02/2002.

${ }^{18}$ Tesão e prazer: memórias eróticas de um prisioneiro foi editado pela Geração Editorial, que é também a casa pela qual foram lançados, entre outros, Pavilhão 9, de Hosmany Ramos, e Vidas do Carandiru, de Humberto Rodrigues, que será objeto do Capítulo 4 da Tese.
} 
transgressões, insiste na relação (conflituosa) com o pai e (amorosa) com a mãe. Procurando entrelaçar sua história à do país, narra o início da vida criminosa ainda garoto, as passagens pelo Recolhimento Provisório de Menores (RPM), os assaltos, as relações amorosas, as idas-e-vindas nas delegacias, convivendo, nos terríveis anos 70, com a tortura - "uma instituição no Brasill", em suas palavras -, com a corrupção de policiais, com a crueldade dos próprios presos. Condenado a quase 100 anos de prisão, vai do desespero por se ver "enterrado" tão jovem (tinha 19 anos) ao alento da descoberta dos livros, como ele gosta de frisar. O livro termina, e seus anos de cadeia, não. Quando publicado, em 2001, Mendes continuava preso. Só sairia três anos mais tarde, a tempo de lançar, na condição de homem livre, seu Às cegas, a continuação de suas memórias.

Memórias de um sobrevivente, além de seus 23 capítulos, tem também um prefácio, escrito por Bonassi, e epílogo do próprio Mendes, duas epígrafes - uma de Sartre, outra de Brecht - e é dedicado aos filhos. Inexistem aqui, ao contrário do que se viu nos outros livros já analisados, reprodução de cartas, espaço para companheiros, glossário ou fotografias. Há, sim, a dedicatória, o que não constitui particularidade de uma escrita do cárcere, embora também faça parte dela, e as duas mencionadas pequenas epígrafes.

Sua não adesão à transformação do livro em espaço compartilhado pelos companheiros de prisão poderia ser vista como seu desejo de se tornar um autor, para o que mobiliza tudo aquilo que reconhece como próprio de um romance e como próprio de um autor de romances. Mendes não se apropria do livro para diferenciá-lo e dar conta das particularidades das formas de sociabilidade do cárcere. Nesse sentido, seu livro está mais próximo do que já se reconhece como tal, o que, talvez, seja fruto de sua maior familiaridade com esse objeto.

Sem, no entanto, poder escapar à prisão, sua prosa é aderente a dois registros distintos, que não se coadunam em nova organização espacial do livro, materialmente falando, até porque, a julgar pelo que conta, tornou-se leitor voraz, capaz de reconhecer - e por que não? - aderir à disposição previamente dada.

Apesar de se distanciar em aspectos vários dos outros livros escritos a partir do cárcere, Memórias de um sobrevivente não recusa a Mendes a condição de presidiário. Ali estão, como nos outros livros analisados, além da adesão dobrada ao regrário dos homens 
livres e dos homens encarcerados, a comparação com o Holocausto ${ }^{19}$; o conhecimento do código penal ${ }^{20}$; a explicação das gírias da cadeia $^{21}$; a imagem da prisão como inferno ${ }^{22}$; os episódios de tortura; a solidariedade ${ }^{23}$; a precariedade material resolvida com engenho ${ }^{24}$; a precisão nas datas ${ }^{25}$; o respeitoso epíteto dedicado aos outros presos: "companheiros de sofrimento"; a preocupação em apresentar o espaço ${ }^{26}$; a incorporação do etos marginal e da

\footnotetext{
${ }^{19}$ A respeito do "bondão", carro que fazia o transporte dos presos do Carandiru ao fórum: "Parecia aqueles carros com escapamentos para dentro em que os nazistas transportavam os judeus" (p. 271).

20 “Agora já sabia que não ficaria preso muito tempo. Como primário em condenações, na minha primeira condenação receberia sursis automaticamente" (p. 335). "Não podíamos ser pegos. Estávamos em flagrante de latrocínio, o pior dos crimes, eu sabia" (p. 362). "Não bateriam mais [em Bala, seu companheiro] porque, em menos de vinte e um dias, a lei dizia que ele teria que ser apresentado ao juiz, após auto de flagrante" (p. 397).

${ }^{21}$ No livro de Mendes, percebe-se o desejo de explicar também o que ele reconhece como pertencente a um ambiente diferente do de seu eventual público leitor - não apenas da cadeia, mas dos bairros pobres. Essa percepção não vem sem certo sarcasmo (e neste caso seria apenas um comentário, e não uma explicação): "Numa brincadeira de taco (beisebol de pobre), tomei uma paulada no olho" (p. 29).

${ }^{22}$ Sobre o DEIC (Departamento Estadual de Investigações Criminais), onde foi torturado: "O medo era o instrumento mais utilizado e aproveitado naquela sucursal do inferno" (p. 300).

${ }^{23}$ A solidariedade dos presos com ele e com os companheiros torturados aparece, por exemplo, em: "Os companheiros de xadrez nos deram banho, lavaram nossas feridas, alimentaram-nos e nos colocaram em um canto, em cima de várias cobertas" (p. 383).

24 "O fogão era um tijolo com ranhuras e, dentro das ranhuras, uma resistência dessas que transformam energia elétrica em calor. Era proibido, resultava até em castigo. Mas na prisão quase tudo era proibido e permitido ao mesmo tempo. Dependia de não deixar o guarda ver, ou, dependendo do guarda, de comprálo" (pp. 404-405). A precariedade material vencida com a astúcia se acentua quando está no "castigo": "Bolamos um esquema. Precisávamos de linhas de costurar bola e duas pilhas pequenas. O Ênio agora estava na faxina e ficava solto, faria a ponte para nós. No dia seguinte, pedimos para ir ao médico, encontramos Ênio e armamos as coordenadas. À noite, fiz o teste. Joguei do meu guichê a pilha com linha na janela da galeria do quarto andar. Ênio, já alerta, amarrou o que pedíamos. Consegui trazer tudo até minha cela e dali distribuí para os outros" (p. 420).

25 "No dia 27 de abril de 1973", Mendes foi transferido para a Penitenciária do Estado.

26 "O pavilhão era assustador. As velhas paredes descascadas de várias camadas de tintas davam um ar de deterioração aos corredores. Aquilo parecia um velho navio encalhado, morrendo, enferrujado, com suas luzes nas janelinhas. Portas de carvalho cheias de trincos e rangidos de castelos mal-assombrados. A cela, em seu interior, trazia as paredes inscritas, em baixo relevo, de cima a baixo; um mundo de nomes e identificações. Tudo era impregnado de mais de cinqüenta anos de sofrimento de várias gerações de presos. Era tudo fantasmagórico, amedrontador. Sentíamos qual estivéssemos entrando em um cemitério, e as celas eram os túmulos" (p. 425).
} 
cadeia $^{27}$; os comentários sobre o "sistema"28; a necessidade da experiência para legitimar a $\operatorname{escrita}^{29}$; o reconhecimento do ler-e-escrever como indícios de prestígio na prisão ${ }^{30}$.

Algumas particularidades de sua escritura precisam ser anunciadas: ao ampliar o arco temporal de suas memórias para além do tempo de prisão, Mendes imprime interesse a seu livro, uma vez que é possível observar a trajetória do menino que vira bandido e que se recupera pelos livros. Além disso, ele faz questão de articular sua vida às transformações por que passavam a cidade e o país: é assim que se acompanham as mudanças na cidade de São Paulo e os tempos sombrios da ditadura do início dos anos 1970 - o que torna seu livro o registro de um tempo feito pelo olhar inusitado de quem passou a maior parte desses anos encarcerado.

O público-alvo também é fator de particularização da sua escrita e da sua posição como autor. Se nos dois livros anteriormente analisados era possível perceber uma intenção ambivalente no tocante a quem aquela escrita, afinal, se dirigia, no de Mendes, o alvo assumido é outro: sua literatura não seria para seus pares $^{31}$ (desenvolvo esse ponto no último item deste capítulo).

Interessa-me pensar no modo como se dá, nas Memórias de um sobrevivente, a oscilação do olhar do narrador. Não me refiro aqui apenas à adesão ao mundo dos homens livres ou ao ambiente da cadeia. Para além da dúplice adesão, aqui presente e à qual dedicarei análise mais adiante, desperta-me a atenção o uso que Mendes faz dos tempos verbais: a oscilação ganha outra dimensão quando associada à inflexão de sua trajetória, não por acaso associada às letras. Mendes escreve após rever seu percurso e suas escolhas. Sua escrita só pode ser compreendida a partir dessa conversão: há um antes (e um jeito de

\footnotetext{
27 "Eu precisava me manifestar. Era a lei do crime. (...) [Se não agisse] teria que calar, baixar a orelha, porque esse era o costume, o código criminal" (p. 409).

28 "Num país em que o desemprego é parte do esquema para manter os salários baixos, o artigo 59 do código penal é um absurdo inominável. No momento em que alguém é mandado embora do emprego, já está infringindo as disposições legais desse artigo. Mais trinta dias e poderá, inclusive, ser apanhado por ter sido desempregado. Além de ficar sem o emprego, ainda vai preso" (p. 232). "Éramos a escarradeira do mundo. Jamais houvera qualquer preocupação em nos reeducar. Tudo era vingança social e contenção" (p. 451).

29 "Quem conhece a muquirana, sabe a força do que estou dizendo" (p. 123).

30 "Fui deixado de lado porque já era um dos mais velhos aqui e porque sabia ler e escrever, quando quase todos eram analfabetos. Muitos pediam que eu escrevesse cartas para mães, namoradas. Fazia até poesia para enfeitar. Dessa maneira, fui saindo do sufoco total que vivera por seis meses" (p. 150).

31 “Os caras podem até me enquadrar, mas eu faço literatura. Uma literatura que é para todo mundo, não só para a periferia" (Folha de S. Paulo, 20/08/2005).
} 
olhar o mundo prévio) e um depois (de onde vem a mirada mais próxima da atual). Está-se diante de um narrador que se mostra em sua compreensão pretérita e presente (no livro, já pretérita, uma vez que entre o fim da escrita e sua publicação transcorrem cerca de 10 anos).

Decerto, se se aceita a premissa de transformação pela escrita, a autopercepção refeita pelo novo olhar apareceria também nos outros livros vistos neste trabalho, mas a dimensão aqui é outra: ao percorrer sua vida de menino a homem feito, a narrativa de Mendes acompanha as motivações de seu narrador-protagonista-autor a cada época. Esse olhar que desliza por entre os anos dá-se a perceber no trato verbal, que se revela construção particular, porque, mesmo revisto, esse olhar não é indulgente consigo. Ao fazer se si uma imagem complexa, nuançada, constrói personagem que o distancia de seus pares.

Tem-se, então, a história do menino, do adolescente, do jovem, que achava que o mundo lhe devia algo e ao qual respondia com violento desprezo, como também a do adulto redimido, que não nega seu passado, ao contrário o assume em seu paroxismo (assassinato, roubo, drogas etc.), mas reivindica novo estatuto para si. Para tanto, contribui a construção de um personagem muitas vezes vil (embora a esse traço acompanhem as fragilidades contingentes). Exatamente porque revê a sua conduta, de que a existência do livro é prova cabal, Mendes pode narrar a si dessa forma.

Neste capítulo, discuto a construção, em Memórias de um sobrevivente, do personagem Luiz Alberto Mendes; o modo como, no trato verbal, na oscilação do olhar, na assunção de certa inescrupulosidade aliada ao receio, revela-se redimido sem negar sua condição; e, finalmente, o estatuto de autor que reivindica.

\section{II.}

"Dona Eida, minha mãe, dizia que até os seis anos eu era um santo. Meu pai, seu Luiz, dizia que eu era um débil mental" (p. 13) - é assim que Mendes começa a sua história. De chofre o leitor é exposto à brutalidade de sua relação com o pai e ao condescendente trato que sua mãe lhe dispensava.

Não demora muito para que o menino associe a existência de regras ao pai opressivo $^{32}$, que o surrava ao mais leve tropeço de conduta. Para escapar ao pai, refugiava-

${ }^{32}$ Mendes chega a, mais adiante, associar o pai a policiais que o torturaram: “(...) deram-me uma sacola para carregar, e fui levado a uma salinha no mesmo corredor. (...) Quando tiraram o conteúdo da sacola é 
se na casinha da cachorra, que o lambia "qual [ele] fosse mais um de seus inúmeros cachorrinhos" (p. 14). A primeira infância em que se via mais à vontade com os animais parece um prenúncio (armado narrativamente) para o processo de bestialização a que seria submetido em suas várias passagens por reformatórios e prisões.

Nos capítulos que dedica à infância, procura construir a imagem de um menino desregrado, insubmisso. Há um olhar pouco complacente consigo mesmo, que, de resto, perpassa o livro, embora assumindo facetas diferentes. Ao se referir ao seu nascimento, por exemplo, Mendes conta que, nas duas primeiras vezes em que a mãe engravidou, a avó patrocinou os abortos. Até que, na terceira vez, Dona Eida teria usado o dinheiro para comprar um armarinho de cozinha. Dali nasceu Luiz Alberto. A idéia de uma origem acidental acentua o lado gauche que parece querer construir para si como personagem.

Essa tendência só se acentua. Observe-se, à guisa de exemplo, este gênero de formulação, impensável nos dois outros livros já analisados: "aos dez anos já era um ladrãozinho bastante bem-sucedido e oportunista". Ou então: "Com onze anos já comprava minhas relações. Não sabia conquistar amigos" (p. 31).

Há, no cultivo dessa imagem de escritor maldito, à la Jean Genet (ao qual, não por acaso, foi comparado $\left.{ }^{33}\right)$, também, um elemento que o diferencia ${ }^{34}$. Não há tentativa de negar os crimes que cometeu, nem de justificá-los; ao contrário, associa-os a sua busca pela felicidade, que, para ele, tinha estreita relação com a possibilidade de consumo ("eu queria viver, e viver significava ter dinheiro, muito dinheiro para fazer o que se gosta", p. 344).

Percebe-se, nesses capítulos iniciais, o que já sugeri: além de evidenciar as transformações por que passa, o olhar aproxima a experiência narrada (quando recupera as

que percebi que carregava os instrumentos de tortura. Ali estavam as ataduras, as cordas de náilon, os fios, os cacetes e a máquina de choques. Recordou-me meu pai mandando que eu buscasse a cinta para ele me bater" (p. 385). A relação ambígua com o pai, guardadas as proporções, vai ser reproduzida com seus algozes, quando, mesmo depois de espancado, afirma: "De repente, transformaram-se em seres humanos. Riram de mim, estavam com pena do meu estado físico e mental, notei até compaixão em seus olhos. Levaram-me a um bar, pagaram-me uma média com pão com manteiga e conversaram amistosamente comigo. E eu gostei deles naquele momento. Inexplicavelmente, eu até os perdoaria, caso não soubesse que aquela manifestação de humanidade era passageira" (p. 395).

${ }^{33}$ Ver artigo de A. Hossne (op. cit.), que, embora não os compare diretamente, discute os meios de legitimação de ambas as escritas.

${ }^{34}$ Imagem presente não só em seus livros, mas também nas entrevistas que concede: "Em Estação Carandiru, do Drauzio Varella, aquelas conversas não têm sentido. Nas histórias, todos eles têm uma justificativa para estar ali. Eu falo: 'Fiz, gostava de fazer, mereci estar preso'. Não faço uma literatura salvacionista. Meu pai era alcoólatra, me batia, mas mesmo assim eu deveria ter me saído bem. Sou um produto de mim mesmo" (Revista O Globo, 30/03/2008, op.cit.). 
sensações e os desejos de então) e se distancia dela (quando salienta que aquilo se dava naquele momento).

Aos doze anos, em sua primeira detenção, já se mostra atento aos códigos dos que pertencem ao mundo do crime, quando recusa, "apesar do frio enorme", uma blusa que outro garoto quis the oferecer: "Meu medo era do que ele viria cobrar depois" (p. 35).

Como também não demora em aderir à norma. Quando tira a carteira de trabalho, ainda menor de idade, acredita-se "homem" (p. 40), em momento de clara valorização do trabalho como indicador de status. Começa a trabalhar como office-boy em um escritório, onde fica durante oito meses.

A dupla adesão de Mendes aos códigos dos homens livres, em momento de reconhecimento da norma, por um lado, e às regras de conduta do mundo do crime e da cadeia - nas Memórias de um sosbrevivente, entendida como qualquer espaço de detenção -, não se dá como nos outros livros analisados. Ele mostra sua aderência hesitante como personagem de sua história: em alguns momentos de sua trajetória, achava que se corrigiria, em outros, tinha clara a intenção de permanecer na vida criminosa. Em Mendes, a percurso é incerto, pendular, e depende, para existir como tal, de um olhar, transformado, que o revisite.

Ainda muito jovem, o desejo de ser visto como malandro, em nova oscilação de conduta, aqui reelaborado de modo crítico no momento da narração ${ }^{35}$ :

"Para eles [os outros meninos] eu já era malandro (e esse era um título que eu queria muito), sujeito esperto a ser respeitado. Adorei o jeito reverente como me tratavam! Gostei mesmo daquilo, deu-me enorme prazer! (...) Queria me mostrar mais malandro ainda, aproveitando a oportunidade para formar minha nova identidade de vez. O prestígio era fundamental" (p. 49).

\footnotetext{
${ }^{35}$ A elaboração crítica aparece em vários momentos, sendo constitutiva do livro. Observe-se, por exemplo, este trecho à página 189, em que comenta como pensava aos dezoito anos: "Estava condicionado a me defender sempre, em qualquer tempo. Sentia que o mundo e as pessoas só me prejudicaram e fizeram sofrer. Não era bem assim, mas era assim que eu via, destacava apenas o que me ferira, valorizava apenas o meu sofrimento, que se fodesse o dos outros. Imaginava não conhecer bondade nem amor" (pp. 189-190, grifos meus).
} 
Nesse trecho, o narrador reforça suas aspirações junto ao grupo de meninos freqüentador da Praça da República e seu desejo de ganhar status, já, contudo, alcançado. Essa necessidade expressa com todas as letras de ampliar o respeito que detinha é um olhar não só retrospectivo, o que pode parecer uma banalidade em um livro de memórias, mas revisitador - no sentido de que Mendes procura expor as razões que, na época, o moviam e acentuar o que via, então, como importante.

Logo começa a freqüentar o Snake, um bar na Galeria Metrópole. Novamente, constrói uma imagem depreciativa, se observada com olhos dos homens livres, a respeito de si e de seu bando:

“Éramos vândalos da pior espécie, aquela que destrói pelo prazer de destruir. Cagávamos nas mesas das casas; cortávamos estofamentos, cortinas, quadros; quebrávamos vasos, bibelôs, estatuetas, televisores, móveis; rasgávamos tudo o que fosse papel etc. Sei lá por quê, mas ao ver coisas bonitas, coloridas, delicadas, o instinto destruidor vinha à tona. (...) Colocava toda a minha raiva, meu ódio naquela atividade destruidora" (pp. 59-60).

Nesse excerto, nota-se o olhar que revisita e perscruta o passado, mas que não o encobre. Repare-se na ausência de subterfúgios quando, para dar conta do perfil destruidor do grupo, recorre ao rude "cagar", que contribui para ampliar o não embotamento do leitor. À virulência da ação destruidora, ele opõe o desconhecimento exato das razões para aquilo, bem como a evocação de "coisas bonitas, coloridas, delicadas".

Muito cedo nas ruas, muito cedo começa a incorporar, como visto acima, o etos malandro, que lhe garantirá a sobrevivência no RPM, nas delegacias e nos presídios por que passaria:

"Aos poucos, fui introjetando o ambiente violento, até modificando meu jeito um tanto meigo e infantil. Fazia parte de tudo aquilo já. Se não fosse pequeno, talvez estivesse abusando dos menores, como faziam os grandes. (...) A moral estava na bunda, e a minha era o meu tesouro" (p. 129). 
A assunção de que, tivesse compleição distinta, agiria com covardia, aproveitandose de outros menores, é formulação característica desse personagem para quem a “introjeção" (note-se o emprego do termo de origem psicanalítica) da violência era responsável por fazer com que o menino antes doce fosse capaz de atos torpes. Fazer parte de "tudo aquilo" implicava agir em conformidade com ditames vis aos quais, aos olhos dos homens livres, não se espera que crianças adiram. Quando opta por mostrar-se dessa maneira, Mendes, por um lado, assume-se desalinhado pelo ambiente hostil em que vivia, por outro, justamente porque escreve sobre isso, com o distanciamento só permitido pelo preciso manejo das palavras, amplia sua revolução pessoal.

Esses momentos alternam-se com aqueles em que Mendes parece querer viver na "ordem":

“Aprender coisas era algo fascinante para mim. Além disso, de repente já era um rapaz. Desejava freqüentar bailes, festas, namorar, viver como um rapaz normal, quando saísse dali [ $\left.\begin{array}{ll}d o & R P M\end{array}\right]$. Queria paz e tranqüilidade, viver como um sujeito de minha idade vivia" (p. 136).

Aos poucos, à medida que as intenções de se guiar pela norma arrefecem, assume a transformação em um "animalzinho mau, agressivo e perigoso" (p. 150). Ainda sobre essa passagem pelo Recolhimento Provisório de Menores, onde era alvo constante de surras dos guardas e dos próprios meninos, conta que:

"Todas as minhas boas intenções de trabalhar, viver com meus pais numa boa, foram se evaporando na medida exata dos dias que ia passando no inferno. Julgava-me traído, roubado, e pensava que não merecia tudo o que passara" (p. 154).

Observe-se o verbo que escolhe para dar conta de seus sentimentos à época: julgarse. O emprego desse termo, que significa "ter-se por", implica distanciamento que fica mais evidente se, à guisa de exemplo, fosse substituído por "havia sido" traído, roubado - o efeito seria por completo outro, e o olhar revisitado de Mendes aderiria ao ponto de vista de 
outrora, o que não ocorre. Dizer que se acreditava traído é em tudo diferente de afirmar-se traído - e Mendes não cai nessa armadilha e, nisso reside, como procuro mostrar adiante, sua particularidade.

Quando, depois de mais de um ano no RPM, é transferido ao Instituto de Menores de Mogi-Mirim, percebe a existência do que venho mencionando existir na cadeia, qual seja, um conjunto de regras rígidas, cunhadas pelos próprios meninos, às quais era dever obedecer. Segundo ele, o "famoso proceder":

"Ali havia, já de modo dominante, o famoso proceder. Conjunto de normas que eram mais fortes que as leis oficiais do Instituto e que nos governavam, implacavelmente. Um sujeito sem proceder era cagüete, veadinho, desprezado, sem direito a tomar atitude de homem com quem mexesse com ele. E uma das regras do proceder era que cada um arcasse com as conseqüências de seus atos. Seria extrema falta de proceder, e portanto colocar-se à execração pública, deixar que outros apanhassem por culpa nossa" (p. 159).

Ao mesmo tempo em que queria ser malandro, bandido, cada vez mais se afastando da possibilidade de retorno à vida familiar, mostra-se reticente quanto a assumir inteiramente a identidade marginal. Por exemplo, quando se recusa a tatuar-se: "Os companheiros enchiam-se de grosseiras tatuagens. Jamais fizera alguma, não queria ficar marcado de modo algum” (p. 189). A tatuagem, como os outros livros a partir do cárcere dão a saber, é uma marca importante entre os presos, muitas vezes sinalizando o crime cometido $^{36}$.

Aos 18 anos, Mendes pensa como um preso: "Todos os meus parâmetros eram de prisão. Em tudo eu pensava apenas como um preso" (p.189). Embora, novamente, aparecessem as oscilações: "Meu pensamento era nunca mais roubar nem me meter em trapalhadas. Todas as idéias anteriores de revolta, assaltos, aventuras, diante da possibilidade de ser livre, sumiam como que por encanto. Agora era maior de idade. Se fosse preso, era cadeia mesmo" (p. 199).

\footnotetext{
${ }^{36}$ Ver, particularmente, Vidas do Carandiru, em que Humberto Rodrigues dedica um capítulo à análise das tatuagens, qual um glossário corporal. Discuto isso no Capítulo 4.
} 
O que parece é que não se está diante de um personagem plano, cujo caminho foi trilhado sem titubeios. Em liberdade, exibe a vontade de criar laços:

"Senti a maior vontade de começar uma nova vida, namorar uma garota séria, casar, produzir filhos e ter paz, amor e tranqüilidade. Percebi na Sílvia [a cunhada] um amor e uma devoção a meu irmão, que me deu inveja dele. Queria ter alguém assim, apaixonada por mim” (p. 209).

Porém, novamente, a resolução dura pouco: “Já não procurava mais documentos e muito menos emprego. Descambava para o crime. (...) Jamais cheguei a tirar os documentos" (pp. 220-221). Atente-se, nesse trecho, à escolha de “descambar", cuja acepção é, em relação às normas, necessariamente negativa, como a convergência do olhar do Mendes menino e adulto, ambos cônscios do desvio.

Vê-se, então, obrigado a mentir à mãe a respeito de uma rápida passagem pela prisão:

"Sabia que era necessário mentir. Ninguém com mais de trinta anos podia entender minhas verdades, justificava. Para mim, meus motivos justificavam os meios plenamente, e pronto. Precisava de capital para financiar a vida que gostava de levar, e todos os meios me eram lícitos e permitidos. Não tinha culpa se os outros haviam nascido antes e se apossado de tudo o que havia. Competia-me buscar minha parte. Afinal de contas, eles não eram, de modo algum, melhores que eu. Pensava assim, imaginando-me com toda a razão do mundo" (p. 226).

A reflexão a posteriori sobre as razões que alegava na época é importante para que se perceba que o amplo arco temporal de que Mendes dá conta traz uma imagem de si reelaborada. Mendes escreve "Ninguém com mais de trinta anos podia entender minhas verdades", numa muito provável alusão à música de sucesso na época "Com mais de trinta" 37 . Além disso, escolhe "justificava", deixando claro que esse era seu modo de ver as coisas à época. Acentua o perfil impaciente e juvenil quando reitera "e pronto". O exagero,

\footnotetext{
${ }^{37}$ Marcos Valle, Garra, de 1971.
} 
também próprio à gente moça, aparece em "todos os meios me eram lícitos e permitidos", formulação neste caso que vai além da retórica. O ressentimento de então também se faz sentir com seu "não tinha culpa se os outros haviam nascido antes e se apossado de tudo o que havia". O narrador termina o parágrafo enfatizando, por meio do emprego (aqui como ao longo do excerto) do pretérito imperfeito: era esse o modo como pensava - a sinalizar, como se preciso fosse, que não adere mais a esse discurso.

Quando se acompanha a trajetória de Mendes, percebe-se, em primeiro lugar, um narrador distanciado temporal mas não afetivamente daquelas ações e que, portanto, pode circunstanciá-las, mas não escamoteá-las. Ele matiza temporalmente sua percepção, tornando-se dois, por meio do uso do tempo verbal. Em segundo lugar, nota-se a hesitação, que torna seu livro mais intricado, entre aderir definitivamente ao "mundo do crime" e optar por uma vida menos arriscada e também mais aborrecida. ${ }^{38}$

\title{
III.
}

À medida que a narrativa avança, o personagem e o trato verbal se tornam mais complexos:

\begin{abstract}
"Nos últimos tempos, minha cabeça mudara muito. Tinha a ver com tudo o que vivera nas prisões. Estava mais calculista, mais violento, prepotente, mais duro e até cruel. Já pouca coisa me importava. Já não me preocupava se tivesse que atirar em alguém. Atiraria agora, sem vacilar. Achava que personificava o crime" (p. 313).
\end{abstract}

O distanciamento temporal, resultado do uso do pretérito mais-que-perfeito e do imperfeito, parece, por um lado, suavizar a postura desumana (por exemplo, ele "estava", não está mais), por outro, ao indicar como pensava àquela época, Mendes não tenta maquiar o que foi - no que se faz respeitar se se levam em conta as regras da cadeia. Revela-se transformado, o que é inequivocamente bem visto de acordo com os valores dos homens livres. Em um único momento parece atualizar seu ressentimento, precisamente quando diz "Atiraria agora, sem vacilar". Embora o advérbio remeta, no contexto, ao

\footnotetext{
${ }^{38}$ Mendes é o único, entre os autores estudados neste trabalho, que assume o fascínio exercido pelo crime.
} Jocenir e Rodrigues dizem-se inocentes, presos indevidamente. André assume certos delitos, mas não aquele pelo qual foi preso. Mas em nenhum momento diz-se seduzido pela vida criminosa. 
passado, é dúbio o suficiente para sugerir a atualidade do ódio, de resto, negada ao longo da história.

Depois de ter se apresentado como criminoso, afirma:

"No fundo, paradoxalmente, eu não era nada disso. Continuava a ser o menino assustado consigo mesmo, medroso e só, de sempre. Carente, profundamente angustiado e agora tenso para conseguir manter a imagem que queria que cultivassem de mim. (...) Queria fama também, sair nos jornais, ter a polícia sempre em estado de alerta por minha causa. (...) Ainda havia um ódio crescente em mim. Não sabia ao certo como, mas todo malandro que fosse metido a bandidão ia se dar mal em minhas mãos. Ia fazer meu nome de bandido em cima deles. E mataria quantos fosse preciso para sustentar tal posição" (p. 314).

A apresentação de si, oferecida como paradoxal, reforça que, por um lado, a imagem é a de alguém que se desprotege ao admitir as fraquezas, a solidão, a necessidade de afeto e atenção. Por outro, diz ele, "continuava a ser" - a indicar uma característica, também um elo com os valores do mundo dos homens livres, que não pode admitir como completamente rompida, porque é preciso que a transformação pelos livros seja crível (fazendo valer o domínio das estruturas narrativas). Em outras palavras: é preciso pôr em evidência que havia, nele, a possibilidade - àquela época ainda distante, ainda remota - de reinserção. Nesse sentido, a escrita de Mendes parece armar narrativamente as possibilidades de reinvenção de seu narrador-personagem, de modo a deixá-lo verossímil na história.

Depois de preso, sob acusação de latrocínio, é submetido a várias sessões de tortura no DEIC. Neste excerto, Mendes revela o alívio em saber que seria transferido para a casa de Detenção, mesmo tendo a certeza de que passaria o resto da vida preso:

"Era terrível, mas eu estava contente com isso [ir para a Casa de Detenção], por mais incrível que possa parecer. Queria era sair daquele inferno [o $D E I C]$. Cadeia não me fazia medo. Agora eu já pensava em não sair mais. Ficaria preso pelo resto de minha vida. Faria da prisão 
meu mundo. Que ninguém se atrevesse a atravessar meu caminho que eu trucidaria. Nada mais importava. E eu só tinha dezenove anos" (p. $395)$.

Atente-se, novamente, ao emprego dos tempos verbais. No primeiro período, quando afirma que "era terrível", faz uso do imperfeito do indicativo, mantendo-se nesse mesmo tempo verbal em seguida: "eu estava contente com isso". Comenta "por mais incrível que possa parecer" - ao lançar mão do presente do subjuntivo ("possa"), e não do mesmo modo verbal no pretérito ("pudesse"), aponta que, diante da brutalidade, o espanto permanece, não sofre transformação.

Adiante, afirma que "agora [ele] já não pensava mais em sair". Novamente, ele se vê às voltas com o advérbio que torna presente a ação descrita, mas que pode ser apenas um indicador de que "naquele instante" era assim que Mendes se percebia. As últimas frases são construídas de modo a expressar eloqüentemente a barbaridade da nova condição. "Que ninguém se atrevesse a atravessar meu caminho" - repare-se que ele não emprega "atreva", o que atualizaria a perspectiva cruel ("que eu trucidaria") que, no entanto, não é mais a sua. Para silenciar o parágrafo e seu $20^{\circ}$ capítulo, escreve: "E eu só tinha dezenove anos". Esse comentário, uma reflexão a posteriori, sugere a percepção dolorosa daquilo em que o jovem Mendes havia se transformado; há aqui o lamento, próprio de um olhar que revisita a trajetória.

O discernimento quanto à situação em que se encontrava vem pouco depois:

"Até que, em agosto de 1972, assinamos o último papel. Era o ciente da decretação de nossa prisão.

Estávamos presos, ilegalmente, desde 18 de maio, passáramos três meses de torturas intensas, agora tudo terminara. O sofrimento havia sido o máximo, envelhecêramos: com exceção do Alemão, estávamos todos com cicatrizes e marcas no corpo e na alma. Ficariam para sempre. Algo fora destruído em nós. Pelo menos o que ainda nos restava de humanidade, pureza e inocência. Agora éramos cobras criadas. O ódio em nós era o mais virulento possível. 
Estávamos cientes de que aqueles que nos barbarizaram o fizeram em nome de uma sociedade. Uma sociedade que nos repelia, brutalizava, segregava, e que quase nos destruía. E o pior: uma sociedade que precisava dessas monstruosidades para se manter. A tortura era uma instituição social” (p. 400).

Note-se aqui a estrutura repetida nos dois últimos parágrafos: “estávamos presos"; “estávamos cientes”, que sugere gravidade e pesar. Olhe-se particularmente para esta última construção: "estar ciente" é estar a par, ter conhecimento, tomar consciência (das brutalidades feitas com ele e seus comparsas). Recupere-se: eles vinham de assinar um documento declarando "estar cientes" de sua prisão, mas na verdade "estavam cientes" da violência a que vinham sendo submetidos sob a tutela do Estado. Mendes usa o mesmo termo - "ciente" - que já havia empregado no primeiro parágrafo em seu sentido substantivo ("o ciente": a assinatura que se apõe a documentos). O substantivo "ciente", comumente associado ao universo jurídico, é subvertido, sem que, com isso, se recuse sua outra acepção, igualmente dicionarizada, em seu uso adjetivo. Mendes aponta o caráter violento e falso - uma vez que ele e seus companheiros estavam presos havia meses - do substantivo, sob o qual a covardia estatal se amparava. Nesse sentido, ele não precisa lançar mão de neologismos, porque, conhecedor da língua, é capaz de, em seu uso culto, revolvê-la. ${ }^{39}$

Lê-se adiante que: "Exigiram que ficássemos nus. Um homem nu perde não sei quanto em porcentagem de sua dignidade. É o método mais usado nas prisões para intimidar, desmoralizar o preso e quebrar sua resistência” (p. 424).

Antes de passar ao próximo item, deve-se examinar, ainda que brevemente, esse trecho. A narrativa da ação é feita no pretérito perfeito (“exigiram”), ação acabada que é, mas, quando comenta a relação entre nudez e dignidade, Mendes escolhe o presente do indicativo, porque parece ainda acreditar nessa vinculação e a apresenta, aos olhos de seu narrador, como ainda aviltante.

\footnotetext{
${ }^{39}$ Uso semelhante é feito neste trecho, em que Mendes se mostra impregnado das regras da prisão: “eu já tinha na cabeça os valores da prisão, estava livre, mas preso por aqueles valores aprendidos no juizado e reforçados na cadeia" (p. 346, grifos meus). Aqui, "preso" se opõe a "livre", porque indicaria a condição de Mendes (detido ou liberto), mas ele o emprega para referir-se a um estado - ter incutido regras que valeriam mesmo quando em liberdade.
} 


\section{IV.}

Como disse no início deste capítulo, há no livro de Luiz Alberto Mendes a aderência ao etos da cadeia. Ponderei que ela não vinha só, mas se articulava a um olhar lançado sobre o que Mendes tinha sido e o que passara a ser no momento da escrita do livro. Comentei também que não há, em seu livro, uma disposição formal de elementos não comumente associados ao livro como objeto. Nesse sentido, ao não ceder espaço aos aspectos tomados de empréstimo à sociabilidade do cárcere, faz uso do livro na forma usual entre os homens livres ${ }^{40}$.

Observe-se mais de perto a adesão de Mendes ao etos prisional:

"O Coroa, com sua inteligência, havia descoberto um meio de colocar a erva para dentro da prisão. Viria no meio das coisas de uso pessoal e comestíveis que as pessoas de fora colocavam em nome deles. Havia descoberto um objeto em que era fácil colocar a droga e que passava pela revista dos guardas sem despertar suspeitas" (pp. 405-406).

Ao não revelar o objeto que serviria à entrada da droga no presídio, Mendes reitera o compromisso com os companheiros e, nesse sentido, faz valer a regra que condena tratar de assuntos internos à prisão fora de seus domínios.

Sua adesão não é inconteste quando diz respeito aos valores, e não exatamente ao regrário, da prisão. Neste excerto, por exemplo, revela certa tibieza de caráter (se olhada pela ótica prisional), quando, depois de matar um homem [Toninho Magrelo, que o assediara] a sangue-frio, sente falta da mãe: "Foi difícil a solidão, cheguei a chorar várias vezes e ainda querer minha mãe. Os anos haviam se passado, e eu ainda era um menino querendo sua mãe" (p. 420).

Como se vê, ao, momentaneamente, recusar a virilidade ${ }^{41}$ que acompanharia o assassino (aqui, vista sob a ótica da cadeia, que permite e louva esse gênero de vingança), percebe-se que não há propriamente um julgamento moral, não há remorsos pela ação, o

\footnotetext{
${ }^{40} \mathrm{O}$ que não impede que os homens livres, vistos como elementos de legitimação, também possam conferir ao livro apropriado de maneira diversa o estatuto de livro.

${ }^{41}$ A esse respeito, ver, de Márcio Seligmann-Silva, "Novos escritos dos cárceres: uma análise de caso. Luiz Alberto Mendes, Memórias de um sobrevivente".
} 
que, sim, indicaria a adesão ao etos do mundo exterior. Mendes simplesmente sente-se só e, ao fazê-lo, recusa o discurso que acompanha o etos do cárcere para revelá-lo insuficiente a sua percepção e sensação.

Um episódio central nas Memórias é quando Mendes é mandado à cela-forte, regime em que o prisioneiro fica sem ver a luz do dia, privado de qualquer contato com os outros presos, bem como de quaisquer objetos, mesmo os mais indispensáveis como roupa, colchão, cobertor. Na cela-forte, Mendes conhecerá Carlão. Sobre esse preso, o leitor já havia sido informado do seguinte:

"Havíamos chegado [à Penitenciária do Estado] em má época. A leva que viera [ da casa de Detenção] antes de nós havia aprontado coisas jamais vistas na Penitenciária. O Carlão e o Jamil, atiçados por alguns presos mais velhos que dominavam a política da cadeia, haviam dado uma rupa ali recente. Saíram, cada um com uma faca na mão, matando e esfaqueando aqueles do pavilhão indicados como cagüetes e informantes. Mataram três e feriram uma meia dúzia.

Jamais ocorrera algo assim na Penitenciária. Fora chocante para $o$ diretor, para os guardas e até para os presos" (p. 427).

Carlão é, portanto, na primeira menção que lhe é feita, descrito como personagem que beira a psicopatia (até mesmo aos olhos brutalizados dos detentos). Uma vez na celaforte, Mendes é amparado por Carlão, que se lhe mostra extremamente solidário. $\mathrm{Nu}$, passando frio, Mendes não conseguia dormir e temia enlouquecer. Carlão, condenado a cinco anos naquele regime, conhecedor dos seus meandros, ajuda-o a comunicar-se pelo encanamento e a obter ilegalmente objetos que minimizassem o seu sofrimento. No oitavo dia, Mendes, já completamente debilitado pelo frio (o castigo consistia em deixar o preso nu os primeiros dez dias de cela-forte), consegue um colchão, mantas e roupas. Ao narrar esse momento, comenta:

"Estava feliz: o frio já era! Carlão poderia dormir tranqüilo, pouco dormira desde que eu chegara ali. Devo-lhe um favor de valor inestimável, impagável. Muitas vezes me acalmou, me ouviu. Em todos 
os momentos que o procurei, encontrei-o sempre disposto a me ouvir e apaziguar. Pode ter matado vários (e matou mesmo), mas para mim foi sempre um grande companheiro" (p. 434).

A última sentença é bastante iluminadora: "pode ter matado vários" (admite a infração ao código dos homens livres), enfatiza esse reconhecimento com o que vem entre parênteses - "e matou mesmo" -, até porque não pode ser acusado de encobrir o fato e ser, por isso, tachado de faltar com a verdade, infração grave no código de conduta dos presos. Em seguida, Mendes defende Carlão e, concomitantemente, a si mesmo: "mas para mim foi sempre um grande companheiro". Note-se que o uso da conjunção adversativa "mas" reforça o conhecimento do código dos homens livres, indicando implicitamente que aquele era um comportamento condenável, ao mesmo tempo em que sugere que, na prisão, a realidade se impõe de modo a rever o julgamento passível de ser feito pelos homens livres.

Sua adesão ambivalente aos dois códigos aparece ainda em outro episódio envolvendo Carlão:

"Quinta-feira era dia de fazer barba, cabelo e tomar banho. Os guardas do Choque abriam as celas, passávamos pelo barbeiro, que raspava nossa cabeça e cara, e entrávamos numa ducha. Numa dessas quintas, que eram como dias de festa para nós, uma vez que saíamos da cela, tomávamos um ar e nos víamos, o Choque nos soltou, e fomos para a ducha. Fiquei no último boxe, como era meu costume, o Carlão ficava em frente. Preso é assim mesmo: cada um estabelece um canto e se acostuma a fazer uso sempre desse mesmo local. Acaba por se sentir proprietário de seus espaços preferidos, e é, de certo modo, respeitado nisso. Cada um estabelece seu território.

Tomava banho quando vi Carlão apanhar uma faca colocada na parte de baixo do boxe dele. Já fiquei em suspense. Enxagüei o corpo rapidamente, enxuguei-me e já fui saindo. Sabia quem ele iria pegar. Não queria assistir. A gente nunca sabe o que pode acontecer em casos assim. Não é bom ficar perto, no mínimo, podemos ser envolvidos como testemunhas, e testemunha não é bem-vista na prisão" (pp. 438-439). 
Mendes revela saber quem seria a vítima de Carlão (“Sabia quem ele iria pegar”), mas, por uma adesão ao código do cárcere, não o diz - parecendo sinalizar que há coisas que não devem "sair da cadeia". Explica, em seguida, a sua pressa em se retirar do lugar onde haveria a confusão provocada por Carlão, revelando ao leitor externo por que não seria bom testemunhar aquela cena. Nesse ponto, mostra como havia introjetado a lógica prisional, embora não a naturalize no momento em que escreve, já que acredita precisar justificar sua atitude ao leitor que não compartilha os mesmos códigos.

Repare-se, ainda, que o verbo conjugado na primeira pessoa do plural acentua sua inclusão em um grupo (o dos detentos), assim como o pretérito imperfeito revela o caráter rotineiro das ações narradas, ampliando a familiaridade com aquele universo. $\mathrm{O}$ comentário, no entanto, é feito no presente do indicativo ("Preso é assim mesmo [...] cada um estabelece seu território"), empregado para tratar do modo como os homens quando presos se relacionam com aquele espaço, comentário possível apenas pelo seu conhecimento do ambiente. O mesmo acontece nas linhas finais do segundo parágrafo, quando ele recorre ao presente do indicativo para enunciar a norma de conduta a ser seguida: "A gente nunca sabe o que pode acontecer..."; "Não é bom ficar perto...", “testemunha não é bem vista na prisão".

Preocupação constante na literatura produzida a partir do cárcere é a descrição espacial. Assim como não se conhecem as regras dos presos, a rotina de um presídio, não se conhecem as celas e os outros espaços nos quais circulam e aos quais não podem escapar. A escrita prisional é uma narrativa também confinada espacialmente. A declaração de que cada um escolhesse um canto ressignifica os espaços.

V.

Luiz Alberto Mendes faz o elogio da ilustração quando narra o momento de sua transformação pelos livros. Se se reconhece transformado pela experiência da leitura, sabe que nem por isso deixa de trazer a dolorosa vivência do cárcere, resultado da falência dos ditames esclarecidos. Assim, admite duas experiências aparentemente opostas e consegue trazer essa dualidade não resolvida para sua escrita. 
Assim como Jocenir e André du Rap, Mendes reconhece que se dirige a um interlocutor de fora: "Ali [na prisão] tudo era pagar. (...) A comida não era distribuída, era paga. 'Pagar um sapo' era fazer uma ameaça" (p. 414). Logo depois: "Estava ocorrendo uma rupa (morte ou esfaqueamento de várias pessoas de uma vez só) no pavilhão 9” (p. 415). As gírias da cadeia aparecem, no livro de Mendes, já atreladas a um comentário, a uma observação que deixe seu autor distanciado daquela linguagem, embora a conheça profundamente.

Apenas nas páginas finais, Mendes irá tratar de sua aproximação com os livros, da transformação que provocaram, dos interesses a partir dali despertos. Por nove meses encerrado em uma cela-forte, descobriu, graças a Carlão, que a situação de incomunicabilidade geral era usualmente driblada pelos companheiros com um sistema de conversas pelo encanamento das privadas. Em uma dessa conversas, sempre à noite, quando os guardas não poderiam surpreendê-los, fala a Henrique, que viria a ser o responsável por revelar em Mendes o gosto pela leitura:

"Henrique tinha o rosto parecido com os dos antigos patrícios romanos. Estava preso havia cinco anos e tinha muitos outros pela frente. Era assaltante de bancos e estava com quatro latrocínios. Fora um dos maiores assaltantes de São Paulo e era muito respeitado por isso. Era uma pessoa boa, extremamente generosa e despojada. Meu maior e melhor amigo de toda a minha vida. O cara parecia aqueles nobres cavaleiros da Idade Média, estava sempre a tomar o partido dos mais fracos e humildes. Estava na cela-forte porque tentava ajudar o Claudinho, seu amigo de infância, a resolver uma questão que nada tinha a ver consigo [ambos haviam tentado matar outro preso, Jorginho].” (p. 438)

Nota-se, logo de início, o emprego de uma construção peculiar - "estava com quatro latrocínios" - para apontar que o amigo havia sido sentenciado por quatro desses crimes. Mendes lança mão de jargão prisional e também faz menção ao etos próprio àquele ambiente quando afirma que "era muito respeitado por isso" - em que "isso" se refere a ser 
um dos maiores assaltantes de São Paulo. Essa é ainda a esfera de valores em jogo - a do verdadeiro bandido. Em seguida, desfia as qualidades de Henrique: bom, extremamente generoso e despojado. Aqui, podem viger tanto os valores do mundo dos homens livres como, a depender das circunstâncias, também os dos presos. "Tomar o partido dos mais fracos e humildes" aparece também em chave positiva, se sob o ângulo dos homens livres, e não necessariamente do da prisão. Ainda que a humildade seja uma qualidade bem-vista pelos presos, Mendes não a exalta em seu livro, como fazem os outros escritores que escrevem a partir do cárcere.

Em seguida, Mendes comenta a razão de Henrique estar na cela-forte: havia tentado matar outro preso - o que é (ou ao menos deveria ser) inadmissível segundo a conduta dos homens livres, mas, na ótica dos presos, absolutamente pertinente, a depender das razões alegadas pelo preso perseguidor (neste caso, não reveladas). Nesse trecho, alguns detalhes são igualmente reveladores. Ao leitor, resta a informação de que Henrique "estava na celaforte porque tentava ajudar o Claudinho, seu amigo de infância, a resolver uma questão que nada tinha a ver consigo". A razão para a cela-forte era, portanto, ter ajudado (nesse sentido, ele é solidário, o que é positivamente visto não importa sob qual ângulo) seu amigo de infância Claudinho (os laços afetivos são amplamente valorizados, como costumam ser também fora da prisão, inclusive sobrepondo-se muitas vezes às leis do Estado) a resolver uma questão (aqui não nomeada; ele havia feito menção ao crime no parágrafo anterior, antes de iniciar sua descrição afetiva de Henrique). Essa não nomeação é em si reveladora da incorporação do etos prisional, em que há coisas sobre as quais se pode falar, outras que não são mencionáveis e pertencem definitivamente ao ambiente da cadeia. Essa questão, salienta Mendes, "nada tinha a ver consigo" - daí seu desprendimento, sua generosidade, configurados como valores positivos. Mas, se vista em chave invertida, ou seja, quando se sabe que ajudar alguém significava matar outra pessoa, não há positivação possível no mundo dos homens livres, e Mendes parece aderir ao etos prisional.

Ainda sobre Henrique:

"O novo amigo falava em livros, contava-me romances que lera, falava em poesia, filosofia, um monte de coisas novas para mim. Foi a 
primeira pessoa no mundo, fora minha mãe, em quem depositei minha confiança total e irrestrita.

As histórias dos livros que contava eram extremamente fascinantes e belas. Ensinou-me a valorizar livros, a querer conhecê-los todos. Agora ansiava sair do castigo para começar a ler aquelas histórias de que ele falava. Era poeta, e eu também quis ser poeta. Prometeu ensinar-me” (p. 438).

A descoberta dos livros - ou ainda nesse momento o imenso desejo de lê-los funciona, segundo conta, como motor para se manter são em situação de extrema violência como a da cela-forte. $\mathrm{O}$ grau de amizade que atribui a sua relação com Henrique é tal que o admite como, além da mãe, o único em quem seria capaz de depositar sua confiança. Notese que a relação se estabelece no ambiente prisional (àquela época ainda mais violento e, sobretudo, menos regulado pelos próprios presos do que nos dias de hoje), no qual cada detento deveria estar sempre alerta para não ser surpreendido por um desafeto. Portanto, a relação de confiança se dá em ambiente de constante desconfiança. Henrique, conta Mendes, o ensina a valorizar livros e a querer conhecê-los - o que talvez pudesse ser lido como pertencente à racionalidade dos homens livres, que prezariam, ao menos em teoria, a ilustração e a instrução como formas de escapar à destruição e à violência. A ambigüidade se mostra quando se considera que ambos - Mendes e Henrique - estavam submetidos ao cruel e irracional castigo da cela-forte por terem matado (no caso de Mendes) ou tentado matar (no que concerne ao seu amigo) outros presos, obedecendo à lógica do cárcere e sendo, por isso mesmo, absolvidos pelos companheiros. Mendes estava agindo corretamente (sob a ótica dos outros presos) ao matar Toninho Magrelo, que queria estuprá-lo e fazer dele "mulher de cadeia"; assim como Henrique e Claudinho provavelmente (sobretudo se levado em conta o prestígio de que gozava Henrique) veriam sua ação ser aprovada se tivessem tido êxito na morte de Jorginho.

O livro, portanto, pode ser a salvação (e a declaração de atribuir a mesma confiança à mãe - o apelo à ordem - e ao amigo que o insere no mundo dos livros não pode ser desprezada), mas a dignidade dentro do ambiente não tem relação com esse objeto. Para salvar-se, é preciso agir em conformidade com as condutas ali expressas. O livro, dessa 
maneira e nesse contexto, aparece como dispensável e pouco familiar, e apenas tangencia a vida no cárcere.

Depois de nove meses de cela-forte, Mendes vai para o regime de observação (que o obriga à permanência em uma cela, agora com janelas, sem direito a sair para o pátio, mas podendo conversar com outros presos). Faz, então, algumas considerações sobre a experiência:

"A cela-forte era uma relação muito estreita com a morte. Muitos se suicidaram ali. (...) Há momentos na vida de um preso em que ele não acredita que exista nada além da prisão. Mesmo vendo a rua pela janela, aquilo parece mais um quadro apenas. Rua é ficção, ilusão" (pp. 442-443).

Comentários como esse são formulados ao longo o livro - eles apontam para o desconhecimento do leitor quanto àquele ambiente, àquela experiência traumática, o que contribui para afirmar que seu público-alvo não contempla os detentos nem tampouco os jovens que flertam com a marginalidade (desejo, no entanto, expresso em Memórias de um sobrevivente e Diário de um detento). Daí a necessidade de reforçar o que não pode ser compreendido. No caso específico de Mendes, esse traço ganha ainda maior relevo porque sua relação com o mundo exterior, supostamente mais letrado, parece se pretender mais efetiva. Almeja - e tem - o estatuto de escritor, conhecedor do cânone literário, como faz questão de ressaltar ao nomear os muitos autores lidos na prisão, mas está indelevelmente ligado à experiência prisional, o que o atrela parcialmente a códigos normalmente diversos dos do mundo letrado.

Mais uma vez, percebe-se que o cerceamento espacial tem implicações sobre um sistema de referências emocionais. Um espaço - que é sinônimo de um castigo - estabelece vínculo com a morte. Mesmo a perspectiva da liberdade, dado o caráter coercivo do espaço carcerário, é vista como falseadora. Aqui, a "amplitude" - negativa - da experiência prisional, que conforma um jeito de (passar a) ver o mundo, revela-se agudamente. 
O interesse pela leitura e pela escrita, esboçado nas conversas com Henrique na cela-forte, ganha contorno mais visível ao sair de lá. A primeira missão de que se incumbe é escrever, com o auxílio do novo amigo, uma carta à mãe, com quem não se encontrava havia dois anos.

No dia seguinte ao de sua saída da cela-forte, Mendes recebe de Henrique "uma pilha de livros, cadernos com poesias e textos dele, papéis, canetas, a carta-rascunho para minha mãe e uma carta dele mesmo". É quando toma contato com a materialidade da escrita, o que acaba por determinar o seu desvio de percurso. Esforça-se para obter novos e mais livros e, para isso, recorre ao auxílio de companheiros que não liam, mas que poderiam solicitar volumes ao bibliotecário da prisão (ele ainda estava em castigo, no regime de observação).

Mendes retoma os estudos, começa a trocar correspondência ${ }^{42}$, a partir do contato com um sujeito que dirigia o "Círculo dos Missivistas Amigos", e lê. Aos poucos, revela, a escrita e a leitura passam a ocupar enorme espaço em sua rotina:

"O crime, a malandragem, a idéia que perseguira desde a infância, de ser bandido, malandro, foram se afastando do meu foco de visão. Agora aquilo era muito pouco para mim, diante dos horizontes que divisava. A cultura, o aprendizado, levavam-me a fazer uma releitura do mundo. Havia um lado melhor, e eu queria pertencer a ele. Claro, a cultura do crime que assimilara desde a adolescência ainda era, de certa forma, dominante em mim, mesmo que então não conseguisse perceber. Estava no meu sangue, nos meus ossos, demoraria a vida toda para conseguir um certo equilíbrio com a cultura social" (p. 469).

No trecho, Mendes revela-se constitutivamente ambivalente: reconhece-se transformado pela experiência da leitura e do conhecimento livresco, que tem em alta conta, mas sabe que nem por isso deixa de trazer a dolorosa vivência que se liga à "cultura do crime". Assim, admite-se como fruto de duas experiências aparentemente opostas e

\footnotetext{
${ }^{42}$ A troca de correspondência, como já se afirmou aqui, é uma atividade a que muitos presos se dedicam e constitui ponto importante de sociabilidade com o mundo exterior. Além disso, como foi visto nos Capítulos 1 e 2, constitui um modo de aproximação com a escrita.
} 
consegue trazer essa dualidade para sua escrita por meio daquilo que caracterizei como olhar revisitado.

Salta aos olhos, ainda, o que vinha se esboçando no livro, e que aqui pode ser delineado com maior nitidez: o uso dos tempos verbais para estabelecer o que era, no que se transformava naquele momento, no que pensava enquanto se transformava e no que pensa quando escreve suas memórias. Observe-se: as idéias de criminalidade esmaecem naquele momento. Novamente, "agora" se impõe como advérbio ambivalente (era-o na época; pode sê-lo também no momento da escrita). Especialmente, aponta para o que não sabia então, mas sabe quando escreve - a "cultura do crime" era dominante nele. Quando afirma que "demoraria a vida toda para conseguir um certo equilíbrio com a cultura social" (que aqui pode ser entendida como a do mundo dos homens livres), sugere que o seu oposto - a cultura do crime, como diz - ainda faça parte de si.

Mendes não recusa sua condição de presidiário naquilo que há de mais radical, se se estabelecer a perspectiva dos homens livres: ele afirma ainda carregar a cultura do crime - e nesse sentido sua redenção não estaria completa. Essa complexidade da imagem que cria para si e que, no limite, o torna um personagem de si próprio é talvez o que melhor o defina.

O epílogo de Memórias de um sobrevivente foi escrito em 2000, pouco antes da sua publicação. Havia ali, entre a redação do livro e a daquela palavra final, um intervalo de quase 10 anos e, em relação aos eventos narrados, 20 anos. "Estou preso, como sempre" - é a frase que abre a cena final de seu livro.

\footnotetext{
"Somo agora quarenta e sete anos de idade, cumprindo vinte e sete anos de prisão. Consegui escapar duas vezes e fui recapturado em ambas, poucos meses ou dias após as fugas. Nos últimos vinte e sete anos, não consegui ficar nem cem dias solto, com fugas e tudo. (...)

Continuo condenado a um montão de anos de prisão, sem perspectivas de quando vou sair, como sempre" (p. 470).
}

Chama atenção, nesse trecho, a recorrência da menção ao tempo de prisão e do emprego da expressão "como sempre". Essa construção contribui para o sentido de gravidade desejado: a de um homem encarcerado a maior parte da sua vida. Conta então 
que chegou a cursar um ano de direito na PUC de São Paulo ${ }^{43}$, que passou dois anos em regime semi-aberto, que casou, que tem dois filhos. Mendes revela que perdera os pais havia pouco e que a sua intenção era "escrever sempre e para sempre". Curiosamente, a mesma expressão que usa de modo redentor (a escrita, sugere, é uma saída) é empregada para indicar o tormento de se ver encerrado numa prisão por toda a vida.

Ele recupera suas expectativas com a publicação das Memórias de um sobrevivente:

"A intenção do livro não foi a de ter uma mensagem. Não tenho essa pretensão. Apenas escrevi para ter uma seqüência que permitisse que eu mesmo entendesse o que havia acontecido realmente. Pois, afora poucos momentos em que estive no comando de minha existência, a maior parte da minha vida transcorreu em uma roda-viva, descontrolada e descontínua. Eu queria ordenar momentos e acontecimentos, ações e reações, para ver se entendia um pouco dessa balbúrdia que foi a minha vida" (p. 476).

A explicitação de que não há de sua parte uma tentativa de conferir a seu livro um caráter exemplar também se mostra importante na sua narrativa. Ao contrário da maior parte dos volumes escritos a partir da prisão, Memórias de um sobrevivente não traz possíveis lições da trajetória de seu autor. Em suas próprias palavras: "Sou de opinião que os fatos, a vida, falam por si mesmos e não carecem de explicações, e sim, tão-somente de narração acurada. As conclusões e ilações, sem dúvida, são pessoais”.

Como já mencionei, Mendes dirige-se a um público que seja capaz de inseri-lo de vez, capaz de alçá-lo à categoria de escritor. Ele depende desse reconhecimento, como deixa claro, ainda no epílogo, quando diz que "Para ele [o escritor Fernando Bonassi, responsável pela publicação de seu livro], eu já sou escritor. Eu ainda espero a publicação deste livro para me considerar como tal” (p. 474). A sua trajetória absolutamente peculiar deve ser, segundo seu desejo, entendida assim: é a partir dessa singularidade que ele se transforma em escritor. Apresentando-se como leitor de Dostoiévski, Henry James e Hegel, é como exceção que deseja ser visto. Por isso, provavelmente, seu livro não tenha

\footnotetext{
${ }^{43}$ Esse período é desdobrado em seu Às cegas, de 2005.
} 
fotografias dos companheiros, não tenha glossário, não seja dedicado aos aliados, mas tenha epígrafe de Sartre e Brecht.

Enquanto para André e Jocenir o livro precisa ser devidamente apropriado para dar conta de suas histórias, para que seja de fato um meio de expressão, Mendes, que conta ter passado vinte anos debruçado em livros, sugere não precisar disso para manejá-los - tratase de um objeto que já lhe é próximo - e nesse sentido aproxima-se de um grupo ao qual quer pertencer.

Persiste, como procurei mostrar, a adesão ambivalente, que ora age em conformidade com o etos da prisão, ora com o mundo exterior (aquele que, da cadeia, lhe parecia uma ficção). Como diz no epílogo: "Há também o fato de que, boa ou ruim, esta é a minha história. Quer dizer: sou o que resulta dai'”44, leia-se: é, como já anunciado, um escritor, sim, mas que passou a vida na prisão, sendo torturado, surrado, humilhado pelas forças do Estado e por outros presos, e que compartilhou os códigos do crime e do cárcere.

\section{VI.}

Ao longo do capítulo, procurei salientar que a palavra de Mendes se destaca das demais em função de um olhar que, percorrendo a própria trajetória, se reinventa. Para tanto, lança mão de um trato elaborado do aspecto verbal. Ao fazê-lo, diferencia o que reconhecia como justo (aos olhos do menino travesso, do adolescente que delinqüia, do jovem bandido) daquilo que, no momento da escrita, considera ainda correto. Não há, ao contrário do que possa parecer à primeira vista, um julgamento moral. Mendes, por meio de seu narrador, em sua tentativa de compreensão, lança olhar condolente mas não benevolente às ações de tempos remotos.

Essa imagem criada de si sugere um personagem que, ao procurar mostrar-se revolvido pela experiência da escrita e da leitura, é capaz de expressar sem tantos senões as covardias, as fragilidades, tudo o que parece reconhecer como capaz de conferir complexidade a um homem, mas também a um personagem que não seja plano. Nesse sentido, mais do que os outros autores a partir do cárcere, consegue questionar a imagem solidificada do bandido.

\footnotetext{
${ }^{44}$ Formulação muito próxima é feita também por André Du Rap e já discutida neste trabalho: "Mas eu não tenho vergonha de ser ex-presidiário, não. É a minha história. (...) é a história de cada um, ninguém se livra dela, ninguém tem outra pra contar" (p. 106).
} 
Se, por um lado, cria um olhar em retrospecto, preocupado em recuperar sua mundividência de épocas passadas, por outro, Mendes, para tanto, faz isso a partir de uma linguagem cultivada, portanto, revista. Observe-se este trecho:

"A felicidade para nós eram armas, carros velozes, mulheres fáceis, droga, bebidas e curtição. Significava liberdade para fazermos o que aprendêramos no juizado e nas ruas, como o mais significativo para uma vida. Sermos bandidos era a glória. O nosso poder parecia infinito dentro do carro, com as armas. Tudo era nosso. Era só descer e tomar. Se tudo o que tinha significado estava nas mãos dos outros, nada mais justo que fôssemos tomar nossa parte. Por que tudo para eles e nada para nós? Cabia-nos buscar nossa parte da maneira como aprendêramos a buscá-la. Todos eram iguais a nós. Estávamos justificados se matássemos, roubássemos. Quem se interpusesse no caminho que seguíamos em busca de nossos objetivos, merecia morrer. Nada mais correto. Tudo o mais parecia irrelevante" (pp. 371-372).

Logo de início o leitor sabe qual o significado de felicidade para Mendes e seus companheiros. Seus objetos de desejo eram, majoritariamente, ilícitos. Associa-os à liberdade e a tudo que aprendera nos institutos voltados para proteção dos menores perceba-se a crítica, sutil, às instituições (eles aprendem nos juizados; o modo como aprenderam é violento). Reconstruindo suas impressões de então, mostra como tentava justificá-las de modo a considerá-las justas a seus fins, de resto, louváveis: a busca pela felicidade.

Olhando o excerto com atenção, depara-se com, para além do assunto tratado, uma escrita castiça, em que se privilegiam os tempos e modos verbais literários como o maisque-perfeito ("aprendêramos") e o pretérito imperfeito do subjuntivo ("fôssemos", "matássemos", "interpusesse"). Vê-se, também, o infinito flexionado, a omissão de sujeito já expresso anteriormente - todos usos próprios a quem domina a língua vernácula. $\mathrm{O}$ uso culto da língua a serviço da narração de tempos em tudo distantes desse mesmo uso acentua, na prosa de Mendes, a sua ambivalente posição. 
O trabalho de composição de Mendes continua. Se se joga luz sobre as construções sintáticas, por exemplo, vê-se que, nos momentos em que recupera mais expressamente formulações de antanho, os períodos são curtos e inexistem subordinações ("Tudo era nosso"; "Era só descer e tomar"). Suas formulações escapam, nesse sentido, ao estabelecimento das relações de sentido além daquelas imediatamente à mão na época e que parecem convergir, inequivocamente, à violência e à pobreza (como se dissessem: eu sou igual a eles - eu posso ter o que é deles; eu apanhei - eu bato).

A essas formulações ("Tudo era nosso. Era só descer e tomar"), segue-se outra, que transforma o mote paratático. Agora, o narrador recupera a formulação de antes, conferindo-lhe sentido a partir do uso da conjunção ("se"), que exigirá, para o estabelecimento de sentido, o verbo no imperfeito do subjuntivo: "Se tudo o que tinha significado estava nas mãos dos outros, nada mais justo que fôssemos tomar nossa parte".

Percebe-se nesse trecho, mas também ao longo do livro, uma concepção elaborada do registro culto da língua, que servirá para, sem subterfugir à condição de presidiário e de criminoso, mostrar Mendes como capaz de regeneração pela escrita e apto a ser considerado um autor. As instâncias de legitimação da escrita, a começar pela editora, reconhecem a capacidade particular que Mendes exibe de controle narrativo e lingüístico.

A oscilação do olhar, em Memórias de um sobrevivente, dá-se também em relação aos códigos reconhecidos como internos à cadeia (e em seu livro também à vida delinqüente) e externos a ela. A criação de um olhar distanciado, pelos anos e pela leitura, das ações passadas se revela em modo especialmente intricado nesse livro de Mendes porque, por mais que procure recuperar as inquietações de tempos outros, apenas a partir do conhecimento que obteve no cárcere mas que não pertence ao cárcere é que foi capaz de formalizá-lo dessa maneira. Se não transige com o que então reconhecia como modo de ser e de escrever daqueles que queria atingir, sua redenção e possibilidade de reinserção dependem de um uso da língua e de instâncias legitimadoras reconhecidas por e pertencentes àquelas mesmas pessoas. Resulta daí essa prosa encrespada de Luiz Alberto Mendes. 


\section{Capítulo 4 (ou "Vivo em dois mundos simultaneamente")}

I.

Vidas do Carandiru, de Humberto Rodrigues, foi publicado em 2002 pela Geração Editorial. Rodrigues, um publicitário de 67 anos, já havia se apresentado ao público que acompanhava a produção emergente das cadeias quando teve seu conto "O futuro a Deus pertence" publicado na coletânea Letras de liberdade ${ }^{45}$.

Seu livro em muito se aproxima dos outros aqui analisados. Estão lá as críticas ao sistema penitenciário, a narrativa do cotidiano e a descrição do espaço prisional, a valorização da experiência, a nomeação dos que lhe são ou foram caros e solidários, as imagens do inferno para melhor definir a experiência numa instituição total, o conhecimento da lei, a salvação pela escrita, a adesão ambivalente ao código de conduta do cárcere - assim como o formato híbrido, a criação de um leitor-em-texto (o "narratário" de tempos idos) claramente externo àquele ambiente.

As singularidades do livro de Rodrigues, no entanto, não tardam a se fazer sentir: além de escrito por um homem de quase 70 anos (“A maioria dos homens com minha idade está pensando em aposentar-se. Eu pensava em como iria reiniciar”, diz ele logo no início), Vidas do Carandiru é o único livro do conjunto aqui analisado que não reivindica a experiência própria já no título. O "diário" de Jocenir, as "memórias" de Luiz Alberto Mendes, a foto de André du Rap na capa de seu livro assumindo o título de "sobrevivente" - todos eles, a seu modo, apontavam para a própria história. Humberto Rodrigues não se furta a fazê-lo, mas não desde o início: a sua história está lá, mas estão também as narrativas das vidas de alguns companheiros de prisão.

Outro aspecto que o distingue dos demais escritores do cárcere tratados neste trabalho é a sua peculiar trajetória: formado em publicidade, segundo conta, havia trabalhado em multinacionais, sempre ocupando cargos de chefia, recebendo altos salários

\footnotetext{
${ }^{45}$ Trata-se de livro de autoria coletiva, fruto de concurso literário feito nos presídios paulistas. Traz, como todos os outros, certas especificidades que mereceriam análise, como a opção por apresentar, para cada um dos participantes, o número de seu prontuário (a fim de que, diz a nota do Editor, os leitores pudessem escrever-lhes), uma fotografia sua e um pequeno perfil. Acompanha cada texto um posfácio de autoria de alguém que venha do mundo dos "homens livres", aí incluídos escritores - como Ignácio de Loyola Brandão, Fernando Bonassi, Ruy Castro -, jornalistas, figuras ligadas aos movimentos de defesa dos presos, juristas e um cantor que já esteve preso, Lobão.
} 
- até que, por razão que não chega a revelar, abre mão dessa vida e passa a viver com dificuldades. É nessas circunstâncias que é preso.

A formação, uma vez na cadeia, lhe garante certos "privilégios" institucionais primeiramente, um trabalho na burocracia do presídio, depois, como professor - e entre os presos $^{46}$. Se Jocenir, André du Rap e Luiz Alberto Mendes preconizam nova posição entre seus pares em função da escrita, Rodrigues também o fará: Vidas do Carandiru mobiliza, com insistência, um certo conhecimento livresco que o diferenciaria dos companheiros. Há reprodução de poemas, citações e epígrafes à exaustão em cada uma das muitas partes de seu livro. Isso será determinante ao modo como constrói uma imagem de si em seu livro, mas também nos arranjos formais que daí resultam, como tento mostrar adiante.

Dividido em várias seções (cada uma com outras tantas subseções), Vidas do Carandiru obedece, grosso modo, à seguinte estruturação: uma parte inicial (composta pelo prefácio assinado pelo jurista Ives Gandra Martins; pelos agradecimentos; e por considerações iniciais, às quais acresce a reprodução do famoso poema "If", de Rudyard Kipling); a parte mais propriamente narrativa (que compreende a sua história prisional; um caderno de fotos com legendas que remetem a trechos do livro; e as histórias de 12 companheiros de Carandiru); uma parte final (em que constam considerações sobre o sistema penitenciário, problemas e soluções; uma "mensagem" final; a publicação do poema "Desejo", de Victor Hugo); e uma espécie de anexo, em que se dedica a explicar o que significam vários vocábulos "da cadeia" ("Glossário") e muitas das tatuagens feitas pelos presos ("Tatuagens").

As reflexões que proponho estão centradas no seu "diário", nas histórias de dois de seus companheiros e no "anexo".

\section{II.}

A parte que chamei de "propriamente narrativa" supõe dois esforços de seu autor: a narrativa da sua detenção e dos seus dias de prisão ("O futuro a Deus pertence") e as 12 histórias de companheiros seus. Nesta parte, atenho-me à narrativa da sua própria história.

\footnotetext{
${ }^{46}$ Um sinal disso é quando, tendo se submetido a uma seleção da Funap (Fundação de amparo ao preso) para tornar-se monitor de $2^{\circ}$ grau no presídio, teme não ser aprovado: "Resta agora aguardar o resultado da seleção. Se eu for reprovado, vai ser um vexame, pois sou tido como intelectual. Afinal, em terra de cego..." (p. 110).
} 
Apesar de, na apresentação do livro, vir à frente da história de seus companheiros, essa seção parece ter sido pensada como publicável depois da recolha das vidas alheias. Rodrigues revela ter tido dúvidas quanto a narrar a sua própria vida, o que condiz com a perspectiva de observador externo que assumirá como meio para aliviar a sua condição de detento. "O futuro a Deus pertence (minha história)" compõe-se de quatro momentos assim enunciados: "Prisão súbita", "A chegada ao Carandiru", "Ironia e injustiça" e "Meu diário", quando a narrativa obedece, como sugere o título, a uma observação regular do dia-a-dia na cadeia. Um momento importante é quando escreve seu registro cotidiano da prisão.

Na primeira entrada do diário, em 5 de julho de 2000, quando chega ao Carandiru (transferido do Depatri), lê-se:

\begin{abstract}
"Vamos para o pátio do Pavilhão II e somos encaminhados até a rouparia (estou com a habitual roupa dos presos em DPs: de camiseta, short e sandálias), para receber uma calça de brim bege, cujo uso, daqui por diante, será obrigatório.

Em seguida somos levados, sempre em fila indiana, para a barbearia e nossas cabeças são raspadas de forma tragicômica, e assim nos sentimos mais presidiários ainda. Depois, tiramos a célebre fotografia de lado e frontal. E após preenchermos as planilhas com as nossas impressões digitais e algumas fichas burocráticas, ganhamos um número de prontuário. O meu é 171.511” (p. 49, grifos meus).
\end{abstract}

Fazendo uso do presente do indicativo, Rodrigues aproxima sua narrativa do registro diário. Revelar o ritual faz com que ele e seus novos companheiros se sintam "mais presidiários ainda", a partir de um corte de cabelo que ajuda a identificar os detentos. Além disso, informa ao leitor as diferenças entre o vestuário do "preso de DP" e do presídio: se lá imperavam o short, a camiseta e o chinelo, a mudança para o Carandiru se faz notar na inconfundível "calça bege" (celebrizada no rap de Jocenir e Mano Brown, para quem o Carandiru era "o país das calças bege"). Há, na narrativa de Rodrigues, espaço para a ironia, quando fala em "célebre fotografia de lado e frontal" - marca facilmente reconhecível (mesmo por parte de um leitor externo à cadeia) dos procedimentos de detenção. Como fará nos contos dedicados à história de seus companheiros, informa o 
número do prontuário, de modo a revelar a assimilação de uma identidade que lhe é conferida pelo sistema penitenciário. Ao tratar das roupas, do corte de cabelo e informar o número do prontuário, Rodrigues marca o ritual de passagem, apresenta-se como um presidiário. O número do prontuário é pouco revelador para os externos ao sistema - ele só faz sentido lá dentro, não só porque inexistente como registro do lado de fora, mas porque determina a identificação de alguém em função do seu crime. Essa tensão, já vista na análise dos outros livros, entre operar a narrativa de modo a ora falar aos seus pares na cadeia, ora àqueles que desconhecem por completo aquele ambiente está presente no diário de Rodrigues, mas de forma bastante particular.

É preciso lembrar que a "forma-diário", embora não rara em textos de teor autobiográfico, repõe a questão de "para quem se escreve". A publicação do diário, justificada pelo autor como uma espécie de caderno de campo (em que ele seria o pesquisador, observador do dia-a-dia da cadeia - segundo Rodrigues, a tarefa que se impôs tornaria menos penosa a temporada no inferno), é elucidativa porque inscreve essas notas em forma de diário numa espécie de etnografia da cadeia, o que, por um lado, o afastaria daquele universo, por outro, supõe o seu conhecimento, a sua empatia, a tentativa de compreender o pesquisado - e é aqui que reside talvez o elemento mais perverso, ainda que óbvio, nesse olhar ambivalente: Rodrigues era também detento. Ele constrói suas observações de modo a mostrar-se surpreendido pelo que se lhe apresenta, como os rituais iniciáticos de uso do uniforme, corte de cabelo, número de prontuário, mas é ele quem passa por aquilo. Aludindo, implicitamente, ao conhecimento que os leitores de fora podem ter da prisão (a célebre fotografia remete a notícias de jornais ou filmes policiais), lançando mão de adjetivos que ironizam o relato, Rodrigues não escapa à própria condição: um homem na terceira idade, com trajetória absolutamente distinta à da grande maioria da população do Carandiru, mas que estava preso.

$\mathrm{Na}$ entrada de dois dias depois, de 7 de julho de 2000, nomeia os companheiros de cela e revela o que cada um supostamente fez:

"Os companheiros são: Pedrinho (32), simpático e extrovertido, era traficante e foi preso com sua companheira. Ela já saiu e ele ainda tem uma caminhada pela frente de mais dois anos. O outro é o Fábio, um 
'pipoca' (preso novato) de 23 anos. Coitado, é totalmente analfabeto.

Foi preso porque estava com o irmão quando este foi roubar um carro.

Trabalha na cozinha como lavador de pratos. Finalmente, o Mohamed (38), um libanês introvertido e revoltado com a prisão, jura que é inocente. (...) Como sempre a solidariedade prevaleceu e me emprestaram lençol, fronha e travesseiro" (p. 51, grifos meus).

A cada mudança de cela ou de setor de trabalho, Rodrigues procederá da mesma forma que aqui: nomeará os companheiros de "xadrez", informando sua idade (entre parênteses) e seu delito, e tecendo comentários sobre cada $u^{47}$. Também exaltará, como aqui, a enunciada solidariedade entre os presos - não circunstancial mas constante ("como sempre"). Nesse trecho, apesar de não deixar de se postar como observador privilegiado daquela circunstância, elogia os valores dos detentos e os nomeia, dando-lhes singularidade, conferindo-lhes identidade que, embora referida ainda aos crimes, aos delitos, ultrapassa a dos prontuários. Esse posto de pesquisador reaparece aqui - e ao longo de todo o livro, culminando no "Glossário" - na necessidade de explicação das gírias da cadeia. Elas vêm sempre entre aspas e são seguidas de parênteses explicativos: ““pipoca' (preso novato)”. Aqui, não há dúvida de que seu leitor esperado é o do mundo além-das-grades.

A necessidade de tradução das gírias, como do cotidiano, da conduta e dos valores, perpassa o diário:

47 A estrutura se repete: "No setor onde estou trabalhando tenho quatro companheiros: o Paulo Alberto (40), encarregado do setor, simpático e inteligente (meio nervoso). Dizem que, na rua, era um grande falsificador. O Garrincha, preso 'piolho' (veterano), beirando os 50 anos, bonachão, está aqui pela segunda vez, e o Otavinho (22). Para ele, eu daria liberdade na hora. É um bom menino, que vai ser pai em breve. Finalmente, o Paulo Elias (40), que é uma figura carismática, vaselina e simpático. Pena que é viciado em crack" (pp. 51-52, 8/7/2000).

"Mudei para o X 200. Agora, os meus companheiros são: o Paulo Alberto (a quem fico devendo este favor), o João (32), um rapaz simples (parece o Tintin, aquele das histórias em quadrinhos), excaminhoneiro, que se envolveu em tráfico de drogas, e um negro nigeriano (35), que tem um nome muito complicado e o apelido de Naná, traficante internacional, que está sempre sorrindo" (p. 56, 8/8/2000).

"Tenho três companheiros, o Valter (56), condenado a 8,8 anos por homicídio: num momento de ciúmes, matou a esposa e já está amargando a prisão há 6,7 anos. Ninguém imagina como ele (uma pessoa simples) foi capaz dessa atitude. Tem o Jaime (37), um pequeno equatoriano, simplório, que foi preso por tráfico de drogas, está aqui há 1,4 ano, aguardando sentença, e finalmente o Crescêncio (44), que está condenado a 14 anos e já pagou 11. Condenado por três tentativas de homicídio e diversas agressões. Agora está mais calmo, é um homem humilde e simples, introspectivo, que se tornou um religioso evangélico bastante dedicado à sua igreja. Fica na sua e não perturba ninguém.” (p. 99, 23/3/2001).

"Novo companheiro no 'barraco'. A exemplo do Marcelo, que já se foi, também é italiano. Seu nome é Marco (47), preso por tráfico internacional" (p. 116, 21/5/2001). 
“'Bonde' é um termo que usamos para designar a transferência de presídio, que normalmente é solicitada pelo preso. Esse tipo de transferência é solicitada por quase todos os presos do Carandiru, que é considerado um depósito de presos. (...) 'Bonde louco' já é bem diferente: acontece quando somos transferidos sem aviso prévio. Acordamos de manhã, o Agente de Segurança aparece na porta do 'barraco' e avisa que temos de descer e nos encaminhar para o transporte, que nos levará para destino ignorado. É uma espécie de castigo, que pode acontecer a qualquer um. (...) Vamos só com a roupa do corpo: a calça, camiseta e um calçado. Não dá tempo nem podemos pegar os nossos pertences, quando muito conseguimos levar a escova de dentes. (...) Fico temeroso e pensando que se isso acontecer comigo e eu não puder pegar os originais de meu livro, vou ficar muito louco, como o bonde. Ainda bem que mais da metade dos originais já está com meu irmão e meu sobrinho." (pp. 114-115, 11/5/2001)

Nesse trecho, percebe-se que, mesmo quando usa a primeira pessoa do plural, Rodrigues põe-se como observador distanciado. Ele imprime um tom próximo ao didático no intuito de relatar situações em que se usam as palavras e expressões mencionadas. As observações mais propriamente pessoais dizem respeito ao livro, àquela altura já bastante adiantado, justamente o que o diferencia dos demais presos.

Rodrigues dedica boa parte do diário a esse relato - em formato de anotações - do dia-a-dia da cadeia, de suas normas de funcionamento. Explica como funciona o horário de visitas (regras da instituição), como se deve proceder quando elas estão no presídio (regras dos próprios detentos, mas absolutamente necessárias ao bom funcionamento institucional), a economia local, com tabelas de conversão em que uma moeda equivale a um maço de cigarros de determinada marca. Como revela neste trecho, quando diz o que fará com os $\mathrm{R} \$$ 100 que recebeu do irmão: "São os próprios presos que lavam nossas roupas. Cada três peças custam uma moeda, que é representada por um maço de cigarros Hollywood. Também vou poder pagar a faxina do 'barraco', que custa dez maços mensais para cada 
companheiro que mora na mesma cela" ${ }^{48}$. Note-se aqui que opõe "presos" a "nós", como a sinalizar que trata de presos específicos, aqueles que fazem trabalhos "domésticos", o que não era o seu caso. $O$ trecho é significativo para perceber as hierarquias existentes na prisão e a necessidade de construir seu lugar a partir da moeda.

Rodrigues revela também aquilo que não é tolerado pelos presos: "O pior é que ele [Paulo Elias] já está devendo para os traficantes. Esse proceder aqui na cadeia acaba em morte" (p. 53); "Dizem que o infeliz [preso morto por outros detentos] havia desrespeitado a esposa de um companheiro no dia de visitas. $\mathrm{O}$ desrespeito à visita quase sempre é fatal” (p. 85). Mantém-se, nessas escolhas, fiel a sua proposta de descrever a prisão. Isso aparece até mesmo quando as regras esbarram na sua própria conduta:

\begin{abstract}
"Como estou sem nada para comer, os 60 reais que arrumei vão servir para comprar alguma coisa (miojo, cigarros, mandar lavar algumas roupas e pagar a faxina do 'barraco'). Estou devendo $\mathrm{R} \$ 20,00$ a um companheiro, que pretendo pagar ainda hoje. Ficar devendo aqui na cadeira não é muito recomendável" (p. 72, 12/12/2000) ${ }^{49}$.
\end{abstract}

A quantia a que alude, obtida com a venda dos seus exemplares de Letras de liberdade lhe permitirá maior dignidade na cadeia (de acordo com todos os códigos, mas também com os códigos prisionais - afinal, esse dinheiro servirá para saldar uma dívida, nada recomendável em ambientes como aquele). Nesse trecho, Rodrigues, ao mesmo tempo em que insiste nas aspas, como a sinalizar que reconhece a todo tempo a impropriedade do uso de certas palavras, mostra-se refém de um modus operandi próprio à prisão: não quer correr o risco de dever naquele ambiente.

Percebe-se do mesmo modo a introjeção do etos prisional quando conta que brigou com o sujeito que substituiu Paulo Elias na cela, mas não revela o porquê. Aqui, como foi visto em trechos de Diário de um detento, Sobrevivente André du Rap e Memórias de um sobrevivente, impera uma adesão inconteste ao "proceder" da cadeia.

\footnotetext{
48 p. $59,11 / 9 / 2000$.

${ }^{49}$ Note-se que a estrutura se repete: narra uma dada situação e, em função dela, vai revelando aos poucos o modo de se comportar na cadeia.
} 
Faz parte do diário - ou do seu caderno de campo - o outro lado do "proceder", já aqui mencionado: a amizade possível entre os detentos ("Quando tenho oportunidade de sair do meu setor de trabalho um pouco mais cedo, passo no X-602, aquele que tem 40 ladrões. Deixei lá bons companheiros e vou bater um papinho com eles”, p. 108), como quando, na última entrada do diário de mais de ano de Carandiru, chega o seu alvará de soltura. Além de nomear aqueles que, de fora, o ajudaram, menciona a reação dos companheiros à boa nova:

"A notícia logo se espalhou pelo pavilhão, como um rastilho de pólvora. Em dois minutos, o salão térreo estava cheio de companheiros e alunos. Fui aclamado, abraçado e jogado para o ar, com uma alegria que demonstrava que o sofrimento é capaz de criar amizades fortes e duráveis, que transcendem o coração. Foi um momento apoteótico. (...) Quando cheguei ao enorme e pesado portão principal, vi com emoção o funcionário manuseá-lo e ouvi o seu barulho que na entrada foi tétrico e agora é uma música celestial. (...)” (pp. 142-143, 18/10/2001).

A construção da imagem da notícia da sua libertação correndo rápido como um "rastilho de pólvora" é especialmente bonita, sobretudo quando se leva em consideração o abuso de chavões de que Rodrigues costuma se valer ${ }^{50}$ - inclusive nesse trecho, quando fala em "transcendem o coração". Para além disso, o excerto elogia os laços fraternos em ambiente hostil como aquele.

Uma parte considerável de seu diário é dedicada à escrita: a decisão de participar do concurso literário que haveria no presídio, a publicação do conto afinal selecionado, o desejo de escrever um livro. Quando trata da escrita, deixa entrever algumas de suas concepções acerca da literatura, do livro e do ofício do escritor:

\footnotetext{
${ }^{50}$ Hélio Schwartsman, em resenha elogiosa a Vidas do Carandiru, faz ressalvas nesse sentido: "O texto é um pouco repetitivo e com alguma freqüência resvala na pieguice, o que provavelmente é um problema comum a todo o gênero literatura de prisão. $\mathrm{O}$ autor também abusa das epígrafes, espalhando-as por todos os cantos do livro. São pequenos defeitos que não chegam a comprometer o conjunto, cuja força, insisto, reside na vivacidade das histórias" ("Vidas do carandiru: instantâneos expõem o sistema prisional brasileiro", Folha de S. Paulo, 21/12/2002).
} 
"Depois de alguns dias pensando e meditando sobre o assunto, resolvi encarar o desafio de escrever um livro. A crônica que escrevi para o concurso literário, apenas sete páginas de sulfite datilografadas, estou transformando em uma história, na qual procuro, nos mínimos detalhes, transportar o leitor para a experiência mais dramática de minha vida. Posteriormente, pretendo escrever algumas histórias de meus companheiros e finalmente complementar com esse diário, tudo autêntico, mostrando o dia-a-dia de um grande presídio, seus dramas, alegrias e tristezas. (...) Pretendo também inserir algumas fotos e ilustrações elaboradas pelos próprios presos. Aqui temos alguns que têm esse dom. O Leno é um deles e já se prontificou a colaborar. (...) Sei que as palavras formam os fios com os quais tecemos nossas experiências e, pelo que vislumbro, elas não serão poucas. Acredito que consiga um livro de pelo menos 200 páginas. Afinal, parece que minha caminhada será um pouco longa. Não posso deixar-me consumir pela revolta, amargura e desespero. O objetivo de escrever este livro há de me ajudar bastante. O desafio é apreciar as coisas boas da vida, em vez de ficar reclamando. (...) Enquanto não conhecemos o inferno, não há paraíso que sirva” (p. 56, 15/8/2000).

Rodrigues intenta, com a escrita, "transportar o leitor para a experiência mais dramática de $[$ sua $]$ vida". Para isso, antevê a necessidade de narrar sua história "nos mínimos detalhes". Sua narrativa, à qual acrescentaria fotos e ilustrações, quer-se “autêntica". O que se percebia nos livros até agora analisados é dito textualmente aqui: a escrita do cárcere pretende-se verdadeira, porque falsear a experiência é romper com os valores tomados para si no cárcere, é desmerecer o sofrimento (seu e dos outros), é ignorar os mortos. A necessidade de um relato fiel está presente, em menor ou maior grau, nesses livros. É preciso inspirar a compaixão do leitor, daí ter de transportá-lo à experiência dramática de sua vida - o encarceramento. Mais uma vez, depara-se com o espectro da incredibilidade e a necessidade de mobilizar recursos vários para se fazer crível: as fotos (documentos) e as ilustrações feitas pelos próprios presos - que ele não chega a incluir de fato em seu volume. Junte-se a isso o informe do seu número de prontuário, a reprodução de excertos de seu alvará de soltura, o conhecimento das gírias locais (“Glossário”) e das 
tatuagens características ("Tatuagens"), e se percebe o mosaico de referências que ancora a narrativa do cárcere. Quando mobiliza aspectos oficiais (prontuário, alvará de soltura etc.), ao mesmo tempo em que aceita a identidade de detento que lhe é designada pelo Estado (a fim de "comprovar" sua passagem pelo sistema penitenciário), utiliza-se dela para relatar os desmandos daquele ambiente (ou seja: vale-se da regra do algoz para lhe apontar o dedo e mostrar os excessos e abusos cometidos naquele lugar). Quando escolhe reproduzir fotos daquele ambiente e desenhos feitos por seus moradores, parece insistir na certificação de sua passagem por lá - agora, acionando os meios extra-oficiais dos detentos (paradoxalmente, como mostram estudos sobre a prisão, as regras dos presos são fundamentais à manutenção da ordem e, nesse sentido, interessam ao sistema penitenciário). Os mínimos detalhes a que alude Rodrigues confeririam a exatidão almejada pelo escritor. Essa "estética" do cárcere é configurada de algum modo no trecho acima. Além disso, chama atenção a imagem que tem da construção de um livro. Para Rodrigues, ele deve ser extenso, deve dar espaço aos companheiros, deve trazer fotos. Ao afirmar essa idéia de seu livro, lança mão de vocabulário mais atrelado ao registro culto ("vislumbro"), no que termina por se distinguir de seus pares.

Para além de alguns procedimentos conformadores dessa escrita, aparece aqui - o que também aproxima Rodrigues do time de escritores egressos do cárcere já tratados neste trabalho - a percepção de que a escrita poderia "salvá-lo" da assim chamada "experiência mais dramática de $[s u a]$ vida”. Isso aparece na própria idéia do diário, depois reproduzido no livro, como também na redação do conto para o concurso e, uma vez decidido que faria um livro, na transformação das histórias dos companheiros em contos ${ }^{51}$. A relação com a escrita passa a ocupar a maior parte das entradas de seu diário. Ele faz comentários sobre o concurso, sobre o livro que dele resultou (reunião com editor, número de exemplares, lançamento, resenhas elogiosas ao seu conto etc.) e, principalmente, sobre o processo de pesquisa e criação:

\footnotetext{
51 "Já terminei a terceira história e estou sempre animado para escrever a seguinte. (...) Refiz a história 'Seus dois amores' mais de três vezes. Tive que fazer a história baseada apenas no processo que meu companheiro forneceu. Ele disse 'se vira e não põe o meu nome; alguns detalhes eu forneço depois'. Como tenho os sábados e domingos com folga, passo esses dias escrevendo. Já não estou me sentindo um preso, mas um pesquisador escrevendo um livro. Não fosse o desconforto do 'barraco' atual, tudo estaria bem” (p. 70).
} 
"No pátio fico analisando meus companheiros e indagando a mim mesmo como será o meu primeiro personagem. Para tanto, procurei conhecer outros pavilhões. É difícil, pois precisamos de autorização para visitá-los. Conheci os pavilhões VIII e IX. A diferença que existe entre eles e o II, onde estou alojado, é a mesma que existe entre a Avenida Paulista e a Praça da Sé. Os Pavilhões VIII e IX têm uma população bem maior e mais heterogênea. Nas suas galerias encontramos gêneros alimentícios, refrigerantes, sabão, pentes, isqueiros. As galerias são pequenas feiras, sempre se encontrando muitas coisas para comprar. Tudo custa o dobro do preço da rua e não tem nada que necessite de geladeira. Aqui no presídio não entram eletrodomésticos, mas, com gorjetas, consegue-se quase tudo. O aparelho de TV entra legalmente, mas é uma burocracia danada, e aqui dentro não podemos negociá-la em hipótese alguma" (p. 58, 10/9/2000).

Nesse trecho, Rodrigues parte da observação de seus companheiros, prestes a se transformarem em personagens da sua história, para chegar à do espaço e da economia doméstica do presídio. Porta-se novamente como pesquisador, valoriza a necessidade da experiência - ele precisa conhecer os outros pavilhões para tratar deles, para ter contato com outros e mais detentos que lhe sirvam de personagens -, estabelece comparações com o mundo externo (quando menciona a Avenida Paulista e a Praça da Sé), numa clara eleição de leitor preferencial, para então mencionar aspectos demográficos e econômicos do presídio. Trata-se de um espaço que não se dá a conhecer para quem é de fora. A função de Rodrigues, neste sentido, passa a ser também a de o apresentar aos leitores. É preciso que eles compreendam, para melhor alcançar a vida no cárcere, como são os pavilhões, como são seus moradores, como é a vida lá (o que se compra, o que não se vende, o que é permitido e o que é interdito, o que é cumprido, o que é burlado). Como é uma vida fechada mas comum (não é um claustro individual), própria a uma instituição total, que disciplina seus habitantes, explorar o espaço e o cotidiano é fundamental para falar da sua vida e da dos seus personagens.

Repare-se ainda no modo como constrói seu depoimento no diário: o "para tanto" que inicia seu segundo período retoma, ao estabelecer nexos consecutivos, aspectos do 
discurso de pesquisador, apontando, em seu relatório, as impossibilidades de acesso a todas as fontes desejadas. A escolha vocabular é igualmente digna de nota: ao optar pelo verbo “alojar" para se referir ao pavilhão onde está preso, Rodrigues nuança a própria condição. Para ele, não apenas a escrita é uma saída para o estatuto de presidiário, mas também o é o modo como em boa parte do texto constrói sua imagem - a de um pesquisador, a de alguém que se mantém, portanto, a uma distância mínima daquele universo ${ }^{52}$. Ele também é, pois, um personagem de sua história.

Aos poucos, o livro assume uma centralidade tal no seu dia-a-dia que tudo aquilo por que passa é elaborado para ser narrado. Neste excerto, de 21 de dezembro de $2000-$ dia do seu aniversário, esclarece -, ele conta que vai depor no fórum da Barra Funda. Rodrigues, como André du Rap, Jocenir e Mendes, também se queixa das condições de transporte e do modo como são tratados os presos ("Parece que somos os piores bandidos do mundo. Será... talvez... quem sabe? Se continuarmos a ser tratados dessa forma, é provável", p. 75), mas o foco está mesmo no livro: "De tempo em tempo, eu perguntava as horas para o guarda, que acabou brincando comigo, perguntando se eu ia viajar, mas era apenas para fazer esse relato" (p. 75); "O meu depoimento foi exatamente o resumo da história que escrevi ('Ironia ou injustiça'), tudo na ponta da língua, pois já a tinha escrito e reescrito" (p. 76).

As suas ações passam a ser intermediadas pela perspectiva de torná-las matéria escrita - daí seu alívio quando, em fins de fevereiro de 2001, depois de mega-rebelião nos presídios paulistas, descobre que seus originais escaparam à destruição. É como se, com isso, preservasse a sua história e a nova identidade (apartada da que sofreu a rebelião).

\footnotetext{
52 “Aos sábados e domingos, como não tenho visitas, passo o fim de semana lendo ou escrevendo. Minha grande frustração é não ter a história de um companheiro para escrever. Fico perdido no tempo e no espaço, como hoje, primeiro domingo de um novo ano. Como alternativa, fico pensando em escrever sobre o dia-adia do presídio, mas isso é rotineiro demais. Minha meta é a espontaneidade das histórias dos meus companheiros e evitar coisas abstratas e subjetivas. No entanto, será que possuo capacidade literária para levar a bom termo esse objetivo? Essa é uma pergunta que constantemente está em meu pensamento. Enfim, escrever este livro foi a melhor alternativa que eu poderia ter encontrado para enfrentar tudo do que estou participando. É um escapismo da solidão, da burocracia, da rotina, da disciplina e do imprevisto. Por tudo isso, invadiu-me uma necessidade tal pelo trabalho a que me propus, que dele passei a precisar como se fosse uma droga. Um fator que compensa o tempo que passarei aqui. Espero que esse tempo todo não seja inútil. Tempo perdido. Acho que tal coisa não existe. (...) Sei que tudo que estou passando servirá para o futuro. Será? Quem sabe? Sei que vale a pena sonhar e sonho. Vivo em dois mundos simultaneamente, já me habituei a não permitir que este ambiente se torne parte de minha vida emocional, ele não é importante. Talvez agora, por estar escrevendo este livro, eu tenha algum interesse. Quando escrevo, não me sinto um preso, apenas um pesquisador que está escrevendo uma obra" (p. 79, grifos meus).
} 


\section{III.}

Em Letras de liberdade, o livro que resultou do concurso de que Rodrigues participou, os contos e crônicas que o compõem são sempre precedidos por foto do autor, ilustração feita por outro detento, e uma espécie de ficha cadastral em que constam nome; informação sobre cor da pele e dos olhos; eventuais sinais particulares; estado civil; data de nascimento; naturalidade; grau de instrução; profissão; apelido (ou "vulgo", como aparece no livro); unidade prisional em que cumpre a pena; data de entrada; número do prontuário; indiciação e condenação. Rodrigues, em Vidas do Carandiru, quando vai contar as histórias dos seus companheiros de prisão, informa os mesmos dados (ou parte deles) antes de iniciar a narrativa propriamente.

Isso tem maior relevância se se leva em conta que, quando o faz, recorre à formatação oficial proposta pelo livro de que é co-autor (Letras de liberdade), mas que partiu de iniciativa do sistema penitenciário pelo qual se sente injustiçado e que fará questão de denunciar ao final de Vidas do Carandiru. Rodrigues, nesse sentido, mobiliza o que reconhece como próprio à narrativa prisional: se em Letras os contos dizem respeito à vida marginal ou à vida na prisão - Rodrigues pretende fazer o mesmo, só que não a respeito da própria história (já o fez), mas das dos companheiros -, parece-lhe natural explorar os recursos que estão à mão. Assim, sempre que dispõe destes dados, Rodrigues fornece nome, apelido, cor de pele e de olhos, prontuário, condenação de seus personagens. Essa escolha é em si reveladora do formato que o livro assume: seu autor não hesita em se apropriar do formato "oficial" quando precisa contar a história de outros prisioneiros, embora, ao contrário do que poderia supor o arrolamento de dados burocráticos, não dispense a seus amigos um olhar acusatório, mas, antes, compassivo. Se ao longo do livro Humberto Rodrigues denuncia o sistema penitenciário, é a ele que recorrerá (ou àquilo que ele oferece) quando desejoso de escrever sobre as trajetórias alheias. Nesse sentido, assume o posto de pesquisador e de observador privilegiado (quando aceita o olhar oficial sobre os detentos), mas também se assume em sua condição circunstancial de detento quando procura explicar as razões que levaram um ou outro ao crime, sugerindo, generosamente, que, não apenas no que lhe diz respeito, a situação de delinqüência pode ser explicada por vários fatores. O olhar compassivo alcança a todos. 
De modo geral, as narrativas contadas em "As histórias de meus companheiros" dizem respeito à vida, antes de sua chegada ao Carandiru, de cada um dos doze homens que escolhe como personagens. Em alguns casos, sobretudo quando o personagem em questão é reincidente, a história pode tratar também do período de encarceramento. Mas necessariamente as narrativas versam sobre o que causou a detenção ${ }^{53}$. Além disso e da "ficha cadastral", trazem uma epígrafe (no início) e uma citação (no final). Quando aparecem, os dados burocráticos, aos moldes de uma ficha criminal, vêm acompanhados de um comentário seu. Quando não há dados criminais e cadastrais, é apresentado um texto (em itálico, de modo a se diferenciar da história de fato) em que faz comentários mais extensos sobre o companheiro cuja história irá contar, divulga a forma como se conheceram, se eram próximos etc.

Aqui, vou me ater a duas histórias - uma delas, a bem da verdade, é um poema escrito pelo preso que seria personagem de uma narrativa de Rodrigues, mas que, ao final, preferiu ele mesmo escrevê-la. A primeira narrativa é sobre um preso chamado Rubens Lima da Silva; e o poema é de autoria de Antônio Donizetti.

\section{III.1.}

Leva o título "Uma alma nobre" a narrativa que Rodrigues dedica a Rubens Lima da Silva. A história vem precedida de uma epígrafe, que faz as vezes de um ensinamento moral de auto-ajuda ("Devemos medir o serviço não pelas cousas feitas, mas pelas dificuldades vencidas"). Ao revelar o número do prontuário de Rubens, o narrador faz um comentário a respeito do tempo de prisão do personagem ("depois que ele chegou, já passaram por aqui mais de 90.000 presos", p. 197) e conta que o "Rubinho" era um preso sem faltas, infrações: "Como ladrão foi exemplar, como preso também tem um procedimento exemplar" (p. 197). A frase ilustra o que venho tentando mostrar desde o Capítulo 1 deste trabalho. Quando escreve "como ladrão foi exemplar", quer dizer que obedecia aos códigos da malandragem ${ }^{54}$ e foi incapaz de burlá-los, ainda que o fizesse se for tomada por parâmetro a lei do Estado. Quando preso, o que o faz exemplar é não ter

\footnotetext{
${ }^{53}$ Nesse sentido, essas narrativas lembram muito algumas das histórias contadas pelo médico Drauzio Varella em seu best-seller Estação Carandiru, espécie de livro inaugural dessa safra de narrativas do cárcere.

${ }^{54}$ Emprego "códigos da malandragem" aqui para designar um conjunto de princípios a ser seguido pelos chamados "marginais" e que pauta a convivência daqueles que "estão no crime".
} 
faltas, não cometer infrações - mas agora não se trata da lei da malandragem, mas da lei do Estado, afinal, é a partir da ficha de prontuário (a que Rodrigues tem acesso por ter trabalhado no setor) que chega a essa conclusão. As esferas se confundem se se pensar que, neste caso, as faltas, mesmo se para a direção do presídio, estão ligadas, obviamente, ao cumprimento das leis estatutárias, mas também a acertos de conta entre os próprios presos, portanto, à lei dos presos. O fato de ser um preso cujo procedimento é visto como exemplar desvela o emaranhado existente entre a esfera oficial, da direção do presídio, e a não oficial, dos presos - uma dependendo da outra para seu bom funcionamento.

O caráter exemplar aqui é ambíguo, porque Rubinho é cumpridor da lei dos presos e da lei dos que os mantêm nessa condição - leis que, teoricamente, não coincidiriam. Percebe-se, uma vez mais, como as formas de sociabilidade, os modos como se entrelaçam as esferas oficial e não-oficial, contribuem para a narrativa a partir do cárcere.

A narrativa se constrói de modo a evidenciar que o caminho delinqüente não é sem dúvidas, sem idas e vindas ou percalços de toda ordem. Nesse sentido, Rodrigues lança um olhar compassivo sobre aquele universo ${ }^{55}$. Conta o narrador que, quando Rubinho havia decidido que "nunca mais faria um assalto", foi preso: "Mais uma vez se via jogado em uma cela escura e infecta, miserável. Justamente agora que tinha resolvido parar definitivamente com o crime" (p. 201). Rodrigues explora, aqui como em outras histórias, uma certa sina perversa que paira sobre esses homens. A idéia de que, a despeito de qualquer intenção de mudar de vida, a vida criminosa era inescapável - ou melhor, uma vez "no crime", difícil dele esquivar-se.

Apenas no fim da história o narrador revela que Rubinho era um sobrevivente ao Massacre de 1992:

"De suas lembranças, poderia contar muitas histórias, sem dúvida, mas a mais trágica o mundo inteiro ficou sabendo: foi o massacre que

\footnotetext{
55 “'Como qualquer obra que leve o título 'Vidas...', o texto de Rodrigues se inscreve na tradição inaugurada por Plutarco no primeiro século da Era Cristã. Mais do que relatar as histórias de seus companheiros presos - os acontecimentos que os conduziram à cadeia -, o autor pretende apreender-lhes as vidas, revelar algo de suas existências morais.

O termo 'existência moral' pode parecer paradoxal aqui, afinal, os biografados não são exatamente varões de Plutarco. Ao contrário, a maioria cometeu crimes bastante graves, que podem incluir homicídio. É curiosa a cumplicidade que se estabelece entre Rodrigues e seus companheiros" (Hélio Schwartsman, "Vidas do carandiru: instantâneos expõem o sistema prisional brasileiro", Folha de S. Paulo, 21/12/2002).
} 
aconteceu em 2 de outubro de 1992, aqui no Carandiru. Afirma que são imagens que jamais esquecerá, com a morte de centenas de seus companheiros e rios de sangue escorrendo pelas escadas das galerias, com presos e funcionários correndo para todas as direções, tropeçando nos cadáveres espalhados por toda parte. Lembra com pavor e tristeza da tropa de choque avançando com tiros e rajadas de metralhadoras. Nada interrompia o avanço de soldados com seus capacetes e escudos, fortemente armados, cães policiais latindo e atacando os presos indefesos. Era um delírio total. Dos que conseguiam correr, poucos escaparam dos golpes de baionetas e dos tiros desferidos por policiais. O pesadelo era mais real do que nunca.

Recorda também que lavaram de sangue o Carandiru para apresentarem uma lista dos 111 mortos. Quem viu e sentiu essa crueldade, que repercutiu pelo mundo inteiro, sabe que foi muito mais. Ele viu os cadáveres empilhados e até hoje não acreditou no que presenciou. (...) Essa é uma chaga da história prisional brasileira, que entre outras não se apagará por muito tempo.

Nessa altura, o Rubinho pára, pensa e diz: 'Sabe, chega, não quero me lembrar de mais nada." (p. 202).

Na leitura do relato não escapam as semelhanças com as lembranças de André du Rap - lá expandidas e repisadas, aqui resumidas e organizadas por um narrador que lhe é solidário mas não sofreu o massacre ${ }^{56}$. Está aqui a imagem, realmente dantesca, dos rios de sangue, como a dos cadáveres espalhados e empilhados; está aqui reiterada a impossibilidade de esquecimento aliada à impossibilidade de crença no que houve; estão novamente os cães latindo e atacando, e a tropa de choque atirando a esmo; está novamente posto em dúvida o número oficial dos mortos - negado pelos que, de fato, viveram a

\footnotetext{
${ }^{56}$ A exemplo do que ocorre em "Pavilhão 9", incluído no livro homônimo de Hosmany Ramos, em que a história narrada é a de Milton Marques Viana, sobrevivente ao Massacre de 1992. Trata-se de uma narrativa de 50 páginas que conta a experiência de Viana na prisão, em particular, a do 2 de outubro de 1992. Hosmany conta que escreveu a história a pedido de Viana, que conheceu na Penitenciária de Avaré. $\mathrm{Na}$ construção dessa narrativa - e destoando do restante do livro -, Hosmany, cujo narrador assume a primeira pessoa do singular, formata seu texto aos padrões que tem sido aqui analisado: fotografias (do autor com Viana e, ao final, um pequeno caderno de fotos com imagens terríveis do massacre), número de prontuário de Viana, citação, nomes dos companheiros, reprodução da lista oficial dos 111 mortos, assim como a denúncia dos descalabros do sistema penitenciário e a necessidade de não deixar o episódio cair no esquecimento, e a percepção de que escapar da morte traz-lhe uma enorme responsabilidade ("missão").
} 
situação. A voz do narrador parece se impor à do sobrevivente quando nomeia o episódio de "chaga" da história prisional, em denúncia dos desmandos do sistema penitenciário.

Quero me ater a dois comentários mais. "O pesadelo era mais real do que nunca" é construção singular porque sugere que os pesadelos sejam em certa medida reais. Quando formula dessa maneira, Rodrigues, talvez dando voz a Rubens, talvez conferindo à história do amigo a sua impressão do cárcere, sugere que a vida na cadeia seja sempre um pesadelo e que a invasão que resultou no Massacre seria um pesadelo ainda pior - o real aqui serve de medida de intensidade: um pesadelo mais real é o mesmo que uma situação ainda pior.

Rodrigues escreve: "Era um delírio total". Há aqui um uso ambíguo do termo “delírio", uma vez que se presta a dupla interpretação, que, no entanto, não exclui uma a outra: que os policiais fortemente armados e acompanhados de seus cães lançavam-se ao ataque tomados de excitação, arrebatamento, como que agiam de modo absolutamente insensato, desatinado.

Esse uso dobrado do termo, no entanto, não é o mesmo a que Rodrigues recorre quando se serve do discurso oficial. A gravidade do relato não o permitiria - parece mais a irrupção do pesquisador que tenta postar-se no lugar do observado, aqui, o policial, mesmo que sem lhe dar razão.

O olhar compassivo que não lança ao policial ele dedica ao seu protagonista, a cuja história dá o título "uma alma nobre". Depois de narradas as muitas contravenções de Rubens, Rodrigues escreve:

“Agora, a surpresa! Os leitores devem estar imaginando que o Rubinho é um bandido com todas as suas características, mal-encarado e truculento.

Ledo engano.

Ele tem feições delicadas, 1,65m de altura, pesa 65 quilos, é meio barrigudinho, educado e prestativo. Bem caracterizado, passa por Papai Noel. É benquisto por todos os seus companheiros e já cumpriu mais de dez anos de prisão.

É professor nas lições da vida. Embora não tenha feito nenhuma faculdade, é diplomado. Durante sua carreira criminosa, levou seis 
facadas, quatro tiros (que acertaram) e fugiu de delegacias de polícia cinco vezes.

Seus companheiros, que foram mais de 25 durante a sua vida no crime, estão todos mortos.

Ele afirma que tinha uma doença incurável, mas garante que através do Evangelho hoje está curado.

Atualmente é coordenador geral das sete capelas católicas do presídio, e sua maior preocupação é a evangelização de seus companheiros. Se tem festa aqui no Pavilhão II, onde está alojado, lá está o Rubinho providenciando as bandeirolas e fazendo o bolo, às vezes com dois metros de comprimento. Se for preciso uma pintura nas galerias, é sempre Rubinho quem cuida. Quando meus óculos se quebraram, foi o Rubinho quem, por intermédio da Pastoral, arrumou um novo par. Para ajudar na manutenção da família, ele faz diariamente doces de leite, pudins de pão e salgados na capela do Pavilhão II, que vende para todos nós. Vende até fiado. Não bebe e não fuma. (...)” (p. 203).

A descrição que faz de Rubens tem em vista desfazer a possível ou provável imagem que o leitor tem ou teria dele. Sugere o que pode ter sido dado a imaginar ao leitor depois de todas as peripécias narradas: "Os leitores devem estar imaginando que o Rubinho é um bandido com todas as suas características, mal-encarado e truculento". Ao estereótipo do bandido ("bandido com todas as suas características"), ele apresenta um homem de feições delicadas, baixo, "barrigudinho" (note-se o diminutivo afetivo) - em oposição ao "mal-encarado" do bandido ideal - e educado e prestativo, em oposição ao "truculento". Para separar as duas imagens de Rubinho, um parágrafo de uma única e curta frase, em que mobiliza expressão popularizada ("Ledo engano").

Insiste na caracterização bondosa do personagem, apesar de seu passado no crime, das fugas, facadas e tiros, quando o compara à figura de Papai Noel. No rol das boas qualidades de Rubinho, estaria ter cumprido mais de dez anos de prisão. Há um pressuposto nessa última idéia: se o antigo bandido já cumpriu dez anos, está pagando sua "dívida com a sociedade" e mereceria um voto de confiança (essa seria a percepção do mundo exterior). Mas, sobretudo, se passou dez anos preso, não conquistou inimizades e 
ainda é comparável a Papai Noel, dignifica-se aos olhos dos presos e do sistema penitenciário.

Aos poucos, revela a conversão de Rubinho à igreja, o trabalho junto à pastoral, lançando mão vez por outra de lugares-comuns como "professor nas lições da vida", sempre de modo a construir para um leitor externo uma imagem positiva de seu personagem. Ao temível delinqüente da imaginação do leitor, o regenerado no cárcere (mas não pelo cárcere, o que é em tudo diferente), a alma nobre de Rubinho.

\section{III.2.}

"Hoje estou aqui" começa com um comentário sobre a formação da maioria dos detentos para destacar uma exceção - Antonio Donizetti, com quem Rodrigues trabalhou no Núcleo de Educação do Carandiru. Conta Rodrigues que, apesar das suas insistências, ele nunca quis the contar a sua história e sempre adiava a narração. Até que Antonio apareceu com uns papéis e lhe disse: "Eu não posso contar a minha história, mas tenho esta poesia, que escrevi nos momentos de solidão e meditação. Se você achar interessante, fica no lugar da minha história". Rodrigues afirma que, depois desse dia, ele sumiu, sem deixar rastro. Comenta: "Nunca vi uma poesia retratar tão bem o seu autor. E resolvi incluir a poesia de um preso neste livro. Aqui dentro também se faz poesia” (p. 251). Em seguida, reproduz o poema ${ }^{57}$.

O poema de Donizetti apresenta estrutura mais narrativa do que lírica. Ao longo dele, impõem-se um verso que funciona como refrão principal ("Hoje eu estou aqui...") e uma expressão-gíria que funciona como refrão de apoio ("Cada um, cada um") -, conferindo-lhe certa estrutura rítmica musical. Percebe-se a intenção de rimar alguns versos entre si e internamente (constante-instante; vi-aqui; lamentos-arrependimentos; é-mulher; correram-sobreviveram; forte-filhotes; lá-lugar-tamanduá; Bradock-Robocop; [sei] lá[deixa pra] lá; acreditar-lugar; lá-dar-gostar; for-dispor), mas não há constância nem regularidade na sua execução. ${ }^{58}$

\footnotetext{
${ }^{57}$ Ver Anexo.

${ }^{58}$ A métrica irregular de seus versos e a inconstância de rima afastariam o poema de Donizetti de uma letra de rap, apesar da existência de um refrão ("Hoje estou aqui") e de o tema (comentários sobre um determinado espaço e situação; uma certa misoginia) pertencer aos topói possíveis do rap.
} 
Provavelmente, é Rodrigues quem acrescenta ao poema de Donizetti algumas notas de rodapé que se prestam ao esclarecimento dos termos "onça" e "tamanduá", reconhecidos aqui como gírias do ambiente prisional (tanto que têm espaço garantido no "Glossário"). Vale a nota de que, nos seus próprios textos, Rodrigues lança mão das aspas e parênteses para sinalizar uma gíria e sua explicação. Aqui, como é texto alheio, usa o recurso notadamente acadêmico das notas de rodapé.

Assim como "selva" é o termo escolhido para se referir ao mundo exterior ("a selva lá fora"), as imagens de animais glosam o mote dado logo no início ("Preso como se fosse um bicho") e funcionam na determinação de alguns comportamentos próprios à cadeia: cobras, piolhos, percevejos, onças, tamanduás, camaleões, leões etc., e variantes verbais como "crocodilar" ("crocodilagem") e "engolir sapos". Quando o sujeito lírico se diz um "animal frio e calculista", assume-se bestializado, mas adere ao termo a adjetivação inteligente, que pareceria colocá-lo no posto de "bandido como deve ser".

A animalização pode ser também recuperada afetivamente - seus filhos são "filhotes", e as namoradas, "gatinhas". Aqui, o "como se fosse" um bicho é assumido, mas deturpado positivamente. Mais uma vez, parece aceitar o estigma (prisioneiro $=$ bicho), mas manejá-lo como convém.

O poema recorre a certos modos verbais mais sofisticados, como o presente do subjuntivo ("Talvez seja"), mas também a fórmulas desgastadas para garantir coesão pela repetição e ênfase ao que vinha sendo dito: "vida esta", "objetivo este", "estruturas essas", "justiça esta", ou "os mesmos" (como sujeito da oração). Trata-se de linguagem própria ao direito, o que sugere certa incorporação - já vista neste trabalho - de estruturas formais próprias às instâncias jurídicas, aqui, empregadas para colocá-las em xeque. Ao mesmo tempo, podem estar sendo usadas porque vistas como sinalizadoras de prestígio.

A estrutura mais narrativa que lírica aparece também em formulações que procuram estabelecer enfaticamente a coesão naquela história: "é como eu já disse anteriormente".

Os ditos populares ("Firme e forte"; "suando a camisa"; "liberdade não se ganha, se conquista") e as referências a Deus ("graças a Deus", "com fé em Deus"), costumeiramente presentes nas narrativas do cárcere, adquirem corpo no poema de Donizetti.

O sujeito lírico remete, ainda, a personagens de filmes de ação (Indiana Jones, Bradock e Robocop) para deles se distanciar ("dentro do meu peito não existe aço") e 
reivindicar o estatuto de um animal "normal" como outro qualquer. O "animal frio e calculista" passa a ser um animal ordinário: não há mais nada que possa distingui-lo dentro da cadeia.

A oposição criada entre "aqui" e "lá" circunscreve o espaço textual de onde fala e cuja referencialidade evidente é a prisão. A “aqui”" associam-se o inferno, "este lugar” ou “onde cobra engole cobra" - inexiste a nomeação do lugar, o que há é sua descrição espacial e comportamental. É preciso que outro, no único momento em que lança mão do travessão como recurso narrativo para indicar o discurso direto, dê nome ao aqui e o circunscreva a "cadeia de segurança máxima".

Tampouco o "lá, ou "lá fora", é digno de nomeação: ele é a selva onde estão os seus “filhotes", mas é também onde está a "liberdade". São, portanto, os dêiticos - marcadores permeáveis - que marcam a oposição entre mundo interior à prisão e o mundo externo a ela. A esperança de "um dia estar lá" e o "lá" tornar-se "aqui" é a tônica do poema e, me parece, de onde vem sua especificidade. "Aqui" e "lá" só se determinam pelo contexto de enunciação e, precisamente por isso, apontam para seu caráter contingente. Por meio do jogo entre "aqui" e "lá", reitera a expectativa de sair do "aqui" inominável e chegar ao "lá".

O sujeito lírico reconhece, ainda, algumas condutas da cadeia e formula algumas considerações desesperançadas sobre o cárcere. Ao construí-las, em mais um valimento de características mais propriamente narrativas, Donizetti emprega conjunções com vistas ao estabelecimento de sentido das ações narradas. Predomina o "mas", que expressa, na maior parte das vezes, ora resignação, ora esperança em relação à idéia à qual se opõe. Nesse ir-evir de expectativas, elabora o que se quer um "retrato" da vida na prisão.

A escolha de Rodrigues por publicar o poema de um companheiro inscreve-se na lógica própria a boa parte da produção literária feita a partir do cárcere: dar espaço para a expressão alheia. Assim, fortalece a sua própria vontade de construir um retrato fiel à prisão, necessariamente um mosaico de vozes.

\section{IV.}

Antes de dar início ao seu glossário, Rodrigues escreve: "Quando se é preso, um dos fatores que nos causam espécie é o vocabulário utilizado nas cadeias, com termos muito característicos. É fácil perceber que algumas gírias são incorporadas à nossa cultura. 
Significados que conseguem traduzir de forma única o sentido das questões sociais. São muitas. Aqui estão as mais conhecidas.” (p. 271, grifos meus)

Atente-se ao modo como Rodrigues se apresenta: inicialmente, é um preso não acostumado às gírias da cadeia, é alguém que, apesar de detido, não pertence àquele universo (que, não raro, está associado ao universo periférico). Assim, é aos presos estranhos àquela linguagem que as gírias causam espécie. Duas linhas abaixo, Rodrigues fala em "nossa cultura", qual seja, a dos homens de fora da prisão. Nos dois casos, ele se posta como o observador distanciado, o pesquisador que, pouco reconhecendo o mundo que visita, precisa lançar mão das aspas para sinalizar que identifica aquele termo como estranho à linguagem que lhe seria própria. Investigando o cárcere, é capaz de compreender o sentido daquelas gírias e indicá-lo nos parênteses que acompanham todos os termos não claramente constituintes da linguagem culta de onde parte o pesquisador.

O glossário que constrói reúne de tudo um pouco: há vocábulos já dicionarizados, outros que não pertencem a um dialeto peculiar à prisão, mas, sim, ao falar da periferia paulistana (atestado nas letras de rap com que boa parte dessa literatura tanto flerta). $\mathrm{O}$ projeto de Rodrigues de construir um A-Z de termos usados na cadeia deve ser entendido como uma tentativa de, ao mesmo tempo em que se mostra conhecedor dos códigos lingüísticos da prisão, reiterar seu pertencimento ao mundo letrado, capaz de distinguir a prisão do além-grades. Ao fazê-lo, parece, mais uma vez, querer ser visto antes como o pesquisador do que como o delinqüente, sobre quem paira o estigma de presidiário.

Algo parecido acontece quando Rodrigues se dedica à exposição das tatuagens que os presos carregam no corpo. A esse respeito, escreve, antes de passar à decifração dos sinais: "Há uma coisa que os presos, em sua maioria, adoram. É o uso das tatuagens. Normalmente, elas são feitas na cadeia de forma rudimentar. (...) São consideradas como códigos secretos. São feitas na palma da mão, ao lado do polegar e normalmente não são reveladas" (p. 291). 
292 圈 VIDAS DO CARANDIRU

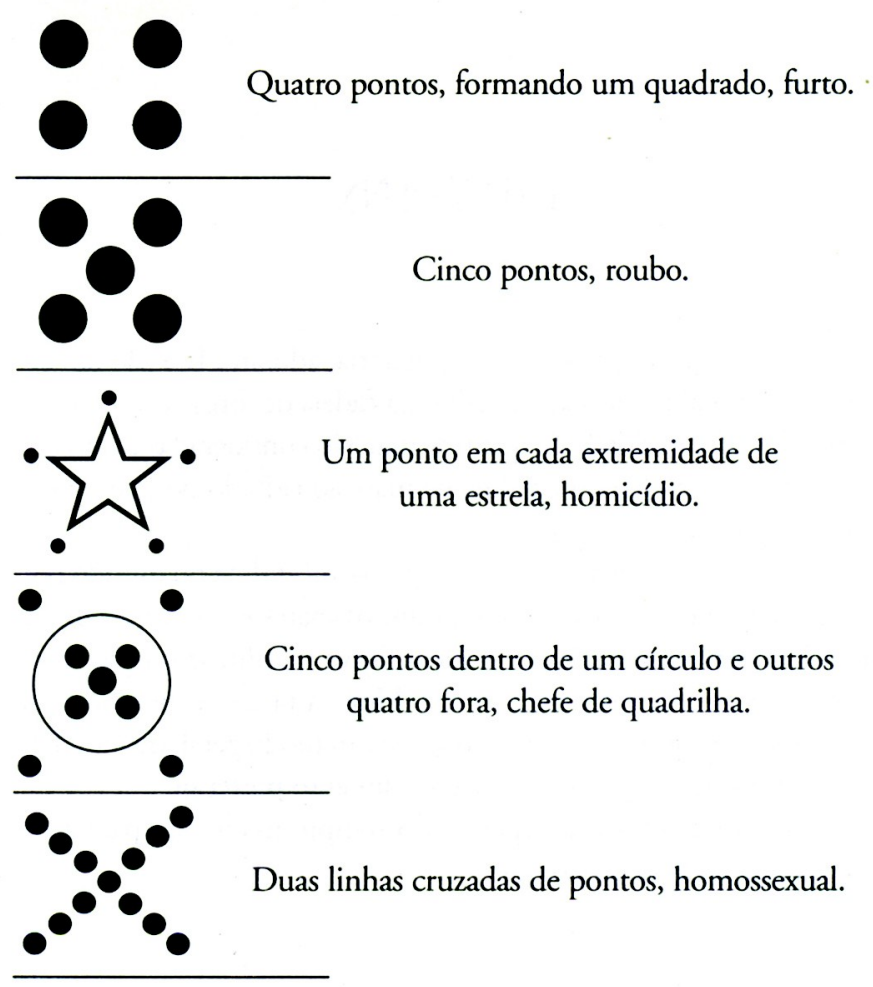

Há outros desenhos usados em outros lugares, principalmente no braço:

Uma borboleta - fugitivo

Coração com flecha - desilusão amorosa

Âncora - esperança e segurança

Cruz de Caravaca - bandido de alta periculosidade

Folha (usada na perna esquerda) Ogum - Corpo fechado e muitos outros.

Já de início, Rodrigues aparta-se do grupo quanto ao apreço pelas tatuagens (os presos adoram, mas isso não o inclui). Ao distanciamento mais evidente, acresce outro, mais sutil, perceptível não mais por uma questão de gosto (os presos adoram; ele não), mas por uma recusa em partilhar os códigos secretos que as marcas no corpo comportariam: "são consideradas" é, em tudo, diferente de "consideramos" - sobretudo porque, 
recorrendo à voz passiva, incorre em elipse (quem as considera afinal?), que se desvela pelo contexto (os que adoram as tatuagens consideram-nas como códigos secretos). A forma como constrói seu afastamento do universo observado (e vivenciado) reitera a ambigüidade ostentada ao longo do livro. Rodrigues é capaz de dissertar sobre os códigos secretos, mas não é um seu usuário. Esse movimento de recusa à identidade prisional assume o paroxismo nessa seção, quando Rodrigues afirma que as tatuagens são vistas como códigos secretos, normalmente não revelados, ao mesmo tempo em que se põe a destrinçar seus sentidos aos quais só teve acesso em função de uma identidade que partilhou com aqueles homens - a de presidiário ${ }^{59}$. Ele só pode postar-se como conhecedor privilegiado do cárcere porque lá esteve como encarcerado, e não, ao contrário do que assumidamente constrói, como visitante. É na qualidade de interno àquele mundo que tem acesso às suas regras e aos seus valores.

Os limites para a sua identificação com tudo aquilo que o cerca ficam claros quando suspende os laços fraternos em nome do projeto do livro - que já vinha tomando a cena no próprio livro. Para dar conta da experiência na prisão, repleta de leis e códigos de conduta tão rígidos quanto específicos àquele ambiente, precisa recusá-la, mesmo se momentaneamente. Ao fazer conhecer o significado dos sinais, verdadeiros estigmas corporais, revela o que não poderia ser divulgado - nesse sentido, descumpre os princípios do cárcere. É capaz de fazê-lo de modo a impor distância ainda maior quando, depois do trecho acima citado, constrói uma pequena mas muito significativa digressão: “A prática da tatuagem é muito antiga: foi difundida no mundo por navegadores que (...) dominavam os mares e o seu uso; desde então, era visto como tabu, pois identificava marinheiros (que eram tidos como arruaceiros e malfeitores)" (p. 291). O modo como mobiliza um certo conhecimento livresco, ao qual volta e meia recorre, contribui para afastá-lo daquele universo. Ainda que pouco rigoroso nas informações que alardeia, Rodrigues se vale delas

\footnotetext{
${ }^{59}$ A esse respeito, escreve Seligmann-Silva: "De resto, é importante lembrar a questão das tatuagens que desempenham um papel central na cultura carcerária. Os policiais lêem, por exemplo, as tatuagens de André du Rap como sinal de que ele é 'matador de polícia' (Du Rap, 2002, p. 109). Assim como Kafka descreve a máquina da colônia penal como uma executora que mata ao escrever o código infringido no corpo do infrator (nas suas costas), do mesmo modo Negrini narra que nas prisões as leis violadas são muitas vezes inscritas sobre o corpo do detento. A tatuagem viola, por sua vez, a lei mosaica que proíbe a inscrição sobre a pele. No universo onde a lei impera do modo mais radical a contravenção está em toda parte. De resto, nas tatuagens vemos marcas escritas sobre a pele que fazem parte da tentativa do prisioneiro reconstruir seu ser despedaçado pela violência." (Márcio Seligmann-Silva, "Violência, encarceramento, (in)justiça: memórias de histórias reais das prisões paulistas”, op. cit., p. 10).
} 
para acentuar seu não pertencimento à prisão, onde a forma de conhecimento por excelência é a experiência ${ }^{60}$.

A opção, no entanto, ao contrário do que poderia parecer, termina por aproximá-lo do conjunto de autores cuja matéria narrativa vem da experiência carcerária.

V.

Ao longo de seu Vidas do Carandiru, Humberto Rodrigues põe em prática um desejo anunciado: distanciar-se da condição de preso a partir da assunção da identidade de pesquisador. Procura, nesse sentido, escapar da dolorosa percepção de que sua história, tão distante da da maioria dos presos, tivesse sofrido inflexão tão significativa. De publicitário bem-sucedido passara a, já em idade avançada, detento do Carandiru.

A escrita, que o afastaria do universo prisional, passa a ser a prioridade no seu diaa-dia, guiando suas ações e preocupações. Transformar o vivido em texto alcança, em seu livro, dimensão ética bastante expressiva. Postando-se como observador privilegiado do cárcere, em função de suas habilidades adquiridas na vida pregressa ao aprisionamento, Rodrigues parece querer afastar-se de vez da imagem de presidiário e livrar-se do estigma que a acompanha.

Por outro lado, o autor, mesmo na condição reivindicada de pesquisador (em um "como se" próprio à ficção), amolda o seu texto, o seu fazer narrativo, ao formato que venho tentando esboçar neste trabalho. A história de Rodrigues antes de chegar à prisão não é suficiente para fazer com que escape à nomeação dos companheiros, à denúncia do sistema penitenciário, à adoção dos códigos de conduta e dos valores ali dominantes, como nos outros livros aqui analisados, ainda que cada um deles, a partir de suas especificidades, o faça em graus próprios e, por isso mesmo, variados. Rodrigues tampouco soube, na tentativa de livrar-se da identidade prisional, escapulir das fotografias (que só não aparecem, no corpus visto nesta tese, em Memórias de um sobrevivente), dos agradecimentos, do espaço concedido aos companheiros de aflição e mesmo dos lugares-

${ }^{60}$ A valorização da experiência como fonte de conhecimento aparece em vários momentos do diário de Rodrigues: "Quando recebemos um 'jumbo', ficamos como crianças, nossos olhos brilham de alegria. Só não sabe disso quem nunca passou por essa experiência" (p. 57, 21/8/2000). "Para escapar da insônia, chego a fazer uma retrospectiva de tudo o que passei, que ninguém sabe, porque ninguém passou por mim" (p. 139, 17/10/2001). 
comuns (que, em Vidas do Carandiru, ao contrário do que ocorre em Diário de um detento, são constantes e muitas vezes, justamente por isso, não dão novos sentidos ao texto).

Claro está que Rodrigues tem razoável domínio das formas consolidadas e respeitadas, lançando mão, em boa parte do texto, de modos verbais e escolhas lexicais mais sofisticados e de uso mais raro naquele meio. Assim como seus enunciados são muitas vezes construídos em estruturas sintáticas de certo apuro. Não se pode ignorar que o excesso de citações (muitas delas, a bem da verdade, parecem extraídas de livros do gênero) revela pertencimento a ambientes mais letrados do que a média. Todos esses artifícios parecem estar a serviço da reivindicação não só de um espaço de autoria (ser autor é, para ele como para os outros três escritores estudados, a possibilidade de escapar), mas de uma autoria que o singularize em definitivo, a partir do domínio do que compreende como próprio das estruturas de prestígio. Assim, tornar-se autor é a chance de recomeçar aos 67 anos - mas é também a de apresentar-se como alguém que só por acaso está naquele ambiente, mas que não pertence a ele, no sentido de que não é esperado que alguém com as suas qualificações ali esteja. A singularização viria, portanto, por meio não apenas da transformação em autor, mas da transformação em autor extremamente diferenciado, em outras palavras, da restituição de sua condição de homem de outra esfera.

Isso posto, a persona de pesquisador vem a calhar porque, uma vez assumida, não falseia a proclamada realidade, já que, com ela, Rodrigues não esconde a situação de preso e condenado. O fato de precisar dela para manter-se são inspira a compaixão do leitor, já tocado pela avançada idade do autor-narrador. A distância, derivada dessa escolha, que ora assume para com seus companheiros, condói (quando parece ser a única válvula de escape para um homem aprisionado) também porque reveladora da necessidade de fugir ao estigma $^{61}$ que acompanha os presos.

Nesse sentido, a escrita passa a funcionar de modo semelhante ao que identificou Erving Goffman em seu Estigma: notas sobre a manipulação da identidade deteriorada: "O indivíduo estigmatizado pode, também [entre outras], tentar corrigir a sua condição de maneira indireta, dedicando um grande esforço individual ao domínio de certas áreas de

\footnotetext{
${ }^{61}$ O termo "estigma" é aqui empregado em conformidade com o estudo homônimo de Erving Goffman: “(...) usado em referência a um atributo profundamente depreciativo, mas o que é preciso na realidade é uma linguagem de relações e não de atributos. Um atributo que estigmatiza alguém pode confirmar a normalidade de outrem, portanto ele não é, em si mesmo, nem honroso, nem desonroso" (p. 12).
} 
atividade consideradas, geralmente, como fechadas, por motivos físicos e circunstanciais, a pessoas com o seu defeito" (p. 19). O domínio da escrita sugeriria o desejado não pertencimento de Rodrigues ao ambiente prisional, uma chance de esquivar-se da condição prisional. Daí o recurso das notas de rodapé, das citações e das epígrafes (demonstrando familiaridade com a cultura letrada e pretensa erudição).

No entanto, quando mobiliza fotografias e dados documentais, como a se proteger da fantasmal descrença que acompanha a literatura feita a partir da prisão, reporta-se novamente à identidade que mais facilmente identifica-se com a prisional. É, afinal, assim que estão construídas as narrativas de Letras de liberdade, livro que fez parte de uma iniciativa oficial do sistema penitenciário e do qual Rodrigues participou. Essa mesma adesão se faz perceber quando Rodrigues valoriza a experiência e a aponta como única possibilidade para quem escreve sobre o cárcere ${ }^{62}$.

Trata-se, contudo, do mesmo autor que se regozija no seu conhecimento livresco. Esse aparente pertencimento a dois diferentes mundos e códigos parece-me ser, na verdade, ainda com Goffman, um desdobramento do estigma:

“(...) o estigma envolve não tanto um conjunto de indivíduos concretos que podem ser divididos em duas pilhas, a de estigmatizados e a de normais, quanto um processo social de dois papéis no qual cada indivíduo participa de ambos, pelo menos em algumas conexões e em algumas fases da vida. O normal e o estigmatizado não são pessoas, e sim perspectivas que são geradas em situações sociais durante os

\footnotetext{
${ }^{62}$ Logo no início de seu livro afirma: "Se alguém sem essa experiência tiver a pretensão de escrever um livro sobre as histórias de um preso, sua vida ou mesmo o dia-a-dia de um presídio, olharei esse livro com incredulidade" (p. 11). Nesse sentido, assemelha-se muito à formulação de Graciliano Ramos em suas Memórias do cárcere, quando se aborrece com o amigo José Lins do Rego, que resolvera escrever sobre a prisão: "O indivíduo livre não entende a nossa vida além das grades, as oscilações do caráter e da inteligência, desespero sem causa aparente, a covardia substituída por atos de coragem doida. Somos animais desequilibrados, fizeram-nos assim, deram-nos almas incompatíveis. Sentimos em demasia, e o pensamento já não existe: funciona e pára. Querem reduzir-nos a máquinas. Máquinas perras e sem azeite. Avançamos, recuamos - nem sabemos para onde nos levam. Zanguei-me com José Lins. Por que se havia lançado àquilo? O admirável romancista precisava dormir no chão, passar fome, perder as unhas nas sindicâncias. A cadeia não é um brinquedo literário. Obtemos informações lá fora, lemos em excesso, mas os autores que nos guiam não jejuaram, não sufocaram numa tábua suja, meio doidos. Raciocinam bem, tudo certo. Que adianta? Impossível conceber o sofrimento alheio se não sofremos. O começo do livro de José Lins $[$ Usina] torturava-me. Quase desejei ver o meu amigo preso. Recusei a afirmação de que a presença dele não nos interessava. Se ele estivesse conosco, jogaria no papel com firmeza as nossas almas aflitas, a morte a pingar, dias, meses, em porões, em cárceres úmidos” (p. 215, grifos meus).
} 
contatos mistos, em virtude de normas não cumpridas que provavelmente atuam sobre o encontro" (pp. 148-149).

Compreendido como relacional, o estigma fornece uma pista alentadora para a interpretação da literatura feita a partir do cárcere e, aqui particularmente, daquela feita por Humberto Rodrigues em seu Vidas do Carandiru. As personas assumidas por Rodrigues (preso e pesquisador) parecem trazer os papéis sociais que ele desempenha.

Sugiro que a disposição material desses livros, bem como o modo como a matéria narrativa é enformada sejam indícios de que as narrativas do cárcere brasileiro tragam as marcas dos modos de sociabilidade daquele ambiente, em que se reconhece a condição de preso mas se almeja outro estatuto (nos casos aqui analisados, de escritores). Quando narrada, a história de cada um desses sujeitos, uma vez submetida às constrições e constrangimentos próprios à instituição prisional, tende, por um lado, a ser disciplinada quando lança mão dos recursos documentais e oficiais (número de prontuário, fotografia, reprodução de documentos e toda sorte de provas que atestem a passagem do autor por aquele mundo), por outro lado, igualmente constrita e constrangida pelos arreios da representação do que seja boa literatura, em um diálogo claramente estabelecido com o mundo de fora, além-das-grades, a história desses homens aponta para possibilidades futuras. 


\section{Capítulo 5 (ou "Neste mundo fora do mundo")}

\section{I.}

Nos 4 primeiros capítulos, procurei, na apresentação de cada um dos livros que compõem a pesquisa, apontar para algumas de suas similitudes formais, temáticas e materiais. É necessário, ainda, recuperar essas semelhanças e discuti-las como próprias de um ambiente que se ancora na coerção. Algumas questões impuseram-se desde o início do trabalho - e merecem agora ampliação.

A escrita prisional parece destinar-se a dois interlocutores distintos: os pares na prisão (mesmo quando não de modo explícito, simplesmente por esses autores não romperem em seus textos com os valores e condutas previstos, numa incorporação de um etos prisional) e os leitores do mundo exterior (nesse sentido, a escrita molda-se a um universo de expectativas do que seja visto como um - bom - livro, ou seja, aquele que satisfaça, segundo certa compreensão, os requisitos necessários para ser considerado pelos outros e por seus próprios autores como tal). Isso aparece na escolha lexical, na estruturação frasal, na recorrência de expressões retificadoras, parênteses, notas de rodapé; na dedicatória, nas fotografias, na reprodução de documentos (sentenças, prontuários etc.), nos agradecimentos, no espaço para a escrita de outros; na necessidade de denúncia dos maus-tratos sofridos na prisão, nas considerações sobre a justiça, nas descrições do espaço, dos costumes, dos valores e das condutas da prisão.

A perscrutação dos livros mostrou que, variando o grau e a recorrência, essas questões apareciam em todos os volumes analisados. Se o fato de esses homens escreverem sobre a própria situação era algo relativamente inédito nas letras nacionais, chamava ainda mais atenção o modo como o faziam: a hibridez desses livros no que diz respeito aos aspectos acima mencionados.

A produção literária surgida da prisão parece estruturar-se em função do confinamento a que eram submetidos seus autores, o qual engendra uma sociedade fechada em si (ainda que reportada ao mundo exterior). Recuperavam-se naquela hibridez os modos de sociabilidade do cárcere, como sustentei nos capítulos anteriores a este. Nesse sentido, não se pode ignorar que a prosa produzida na cadeia é feita a partir dos constrangimentos sofridos por quem está em reclusão, participando, forçadamente, de um ambiente fechado, 
de obrigatória proximidade física com outros homens ${ }^{63}$. Nesse ambiente, é preciso rapidamente reconhecer as regras de funcionamento a fim de garantir a própria sobrevivência. Há uma necessidade de assimilação dos códigos e valores muito particulares que são não só norteadores como definidores da convivência forçada. A prisão teria um modus operandi, segundo as narrativas aqui analisadas, semelhante ao da sociedade de corte, tal qual pensada por Norbert Elias, porque pautado por um etos próprio e definidor da sobrevivência. ${ }^{64}$

Do universo prisional, ao contrário do que ocorre na corte, não se pode escolher participar. O constrangimento, aqui, é coerção física: a violência moral é também física. A prisão funcionaria como uma corte às avessas: não se está diante de uma elite que pauta comportamentos aos cortesãos, não se está na ponta da pirâmide, mas no que pode haver de mais basilar do terceiro estado: homens infratores que ditam regras para outros tantos infratores.

Mas cabe a esse universo o que o sociólogo afirma logo a seguir:

"Tais normas não podem ser esclarecidas a partir de um mistério encerrado no peito de grande número de homens singulares; elas só podem ser esclarecidas em conexão com a figuração específica que os muitos indivíduos formam conjuntamente, e com as interdependências específicas que os ligam uns aos outros" ${ }^{35}$.

\footnotetext{
${ }^{63}$ Em livro feito após o Massacre de 1992, Elói Pietá e Justino Pereira afirmam: "A falta de privacidade é um dos principais problemas do presídio. É impossível alguém conseguir ficar sozinho por um segundo sequer. Como alguém que tivesse as pálpebras cortadas, o detento está condenado a sempre ver o outro, a não esquecer jamais da condição em que se encontra" (Pavilhão 9: o massacre do Carandiru, p. 19, grifos meus).

${ }^{64} \mathrm{Na}$ sociedade de corte, afirma Elias, “(...) encontramos um outro sistema social de normas e valores, cujos mandamentos são obrigatórios para os indivíduos" (Norbert Elias, A sociedade de corte, p. 85). Uma razão pela qual talvez se devesse usar com parcimônia a análise de Elias é de que a sociedade de corte se pauta por uma racionalidade pré-burguesa, e os presos são, em sua maior parte, reflexo da consolidação da sociedade burguesa. No entanto, uma vez dentro da prisão, a lógica que passa a imperar, embora com fundamentos econômicos rudimentares, já que é proibida a circulação de dinheiro nos presídios, é a das coerções de interdependência que podem render maior ou menor prestígio e poder. Ainda que assim não fosse, a análise de Elias debruça-se em sociedade que, a exemplo da prisional, fecha-se em si.

${ }^{65}$ Idem, ibidem.
} 
Essas interligações que produzem "códigos e comportamentos originais" 66 está na base das relações prisionais, de uma "sociedade" fechada em si, mas que, para existir, precisa reportar-se ao mundo exterior. Se na corte a existência dos não-cortesãos servia, pela diferença, para confirmar a distinção dos cortesãos, na cadeia o mundo exterior é que é visto como sinal de privilégio. Se, como pretendi mostrar nos capítulos anteriores, a escrita produzida a partir da prisão retoma os modos de sociabilidade do cárcere, é preciso entender como esse "modo específico de dependências recíprocas" se configura na escrita produzida a partir de um ambiente coercivo.

Na prisão, a rede de relações se dá entre os próprios presos - respeitadas hierarquias várias -, entre os presos e os funcionários (aqui entendidos como todos aqueles que possam ser vistos como sinônimo de manutenção da ordem - incluem-se, portanto, os guardas dos presídios, os carcereiros, os policiais, os funcionários de fóruns etc.), entre os presos e seus familiares/ visitantes.

Nas narrativas estudadas, encontram-se situações que tratam na maior parte do tempo da relação entre os próprios presos (quando estes se debruçam sobre a vida na prisão), mas também tratam da relação que os detentos entretêm com os funcionários, notadamente aqueles que não fazem parte do funcionamento da cadeia ou do presídio, mas os guardas responsáveis pelo transporte até os fóruns, a tropa de choque, ou estafe de algum modo ligado ao sistema judiciário: os psicólogos (responsáveis por pareceres que podem amainar a pena), advogados, juízes etc. As narrativas são especialmente queixosas com aqueles funcionários que não estão no ambiente da cadeia, mas que, de alguma forma, contribuem para que a permanência de seus autores lá se dê em condições custosas emocional e fisicamente ${ }^{67}$.

Uma prosa que surge do confinamento em grupo impõe-se como uma escrita que não pode escapar à dimensão coletiva do que se narra, mas que pleiteia a especificidade em um ambiente sem possibilidade para isso. Arma-se daí uma prosa que reivindica em sua forma a tensão que a constitui.

\footnotetext{
${ }^{66}$ A expressão é de Roger Chartier na introdução que fez a $A$ sociedade de corte: "Formação social e habitus: uma leitura de Norbert Elias", p. 93.

${ }^{67}$ "Em frente a um juiz gordo, cheio de empáfia, decerto julgando-se parceiro de Deus no julgamento dos míseros presos subumanos, fui réu confesso" (Luiz Alberto Mendes, Memórias de um sobrevivente, p. 336).
} 
Ao longo deste trabalho, viu-se que a chegada ao ambiente prisional supunha um ritual de iniciação. Este se dava tanto pela via oficial, com a raspagem dos cabelos, a indicação da obrigatoriedade do uso do uniforme, do seguimento de horários e regras, como - mais importante - pela via extra-oficial, a dos presos. A aprendizagem do regrário prisional (ditado pelos próprios encarcerados) requeria de um preso novato uma observação atenta e discreta dos à sua volta. Essa iniciação é sociologicamente semelhante ao processo de curialização descrito por Elias e comentado por Chartier:

“(...) a vida de corte requer dos que nela participam propriedades psicológicas específicas, que não são comuns a todos os homens: é o caso da arte de observar os outros e de se observar a si próprio, a censura dos sentimentos, o domínio das paixões, a incorporação das disciplinas que regulam a civilidade. Uma tal transformação não modifica apenas as maneiras de pensar, mas toda a estrutura da personalidade, a economia psíquica que Elias designa por um termo antigo, o Habitus. O processo de curialização é também um processo de remodelação da afetividade (...) que submete o homem de corte a uma rede apertada de autocontroles automáticos que refreiam todos os impulsos espontâneos, todos os movimentos imediatos. Este habitus inédito produz uma forma de racionalidade inteiramente específica, dita höfische Racionalität (Racionalidade de corte), que deve adequar exatamente cada conduta à relação onde ela se inscreve e adaptar cada comportamento à finalidade que ele deve permitir". ${ }^{6}{ }^{8}$

Interessa-me, portanto, discutir o modo como a racionalidade prisional $^{69}$ se inscreve numa forma própria. Parto, para tanto, de uma premissa já aqui explicitada e que retomo apenas para fins de clareza - a de que os modos de sociabilidade do cárcere inscrevem-se na literatura produzida a partir daquele ambiente.

\footnotetext{
${ }^{68}$ Roger Chartier, op. cit. p. 113.

${ }^{69}$ Veja, a esse respeito, o que se lê nas Memórias de um sobrevivente: "Todos os meus parâmetros eram de prisão. Em tudo eu pensava apenas como um preso" (p.189); "eu já tinha na cabeça os valores da prisão, estava livre, mas preso por aqueles valores aprendidos no juizado e reforçados na cadeia” (p. 346). Ou em Sobrevivente André Du Rap: "A sociedade aqui fora é totalmente diferente do nosso mundo, do mundo que você vive atrás das grades” (p. 186).
} 
A sociabilidade do cárcere supõe um entrelaçamento do que, ao longo deste trabalho, chamei de condutas e dos valores prisionais. Uns diferem-se dos outros por formarem as primeiras um conjunto de regras imposto pelos e aos detentos ${ }^{70}$; e os segundos, por pautarem uma junção de traços compartilhados. Às vezes condutas e valores têm limiar de difícil determinação. Podem se sobrepor, como quando são narradas cenas cujo desfecho, porque envolveria a revelação de detalhes da dinâmica prisional, é omitido: trata-se da explicitação de uma regra (há coisas sobre as quais é preciso silenciar, porque são próprias da cadeia) e de um valor (não se deve dizer aos de fora as coisas próprias ao cárcere $\left.^{71}\right)$.

Trata-se, portanto, de condutas e valores próprios ao universo prisional, mas que, para existir, dependem da expectativa de "estar-fora" daquele ambiente. Os textos reportam-se a todo tempo ao que chamei de "mundo além-grades", revelando a ambivalência própria à condição de encarcerado ${ }^{72}-\mathrm{e}$, no que me interessa mais propriamente, à escrita produzida a partir do cárcere.

Os laços que constroem na prisão e que formarão os valores partilhados são, segundo Erving Goffman, próprios às instituições totais, onde os "internados" desenvolvem um processo de confraternização que funcionará como modo de apoiarem-se mutuamente e resistirem a um sistema que os forçou à intimidade. Lá, “(...) tendem a desenvolver-se um

\footnotetext{
${ }^{70}$ Luiz Alberto Mendes, em seu Memórias de um sobrevivente, conta que, já no Recolhimento Provisório de Menores (RPM), havia uma conduta a ser seguida:"Ali havia, já de modo dominante, o famoso proceder. Conjunto de normas que eram mais fortes que as leis oficiais do Instituto e que nos governavam, implacavelmente. Um sujeito sem proceder era cagüete, veadinho, desprezado, sem direito a tomar atitude de homem com quem mexesse com ele. E uma das regras do proceder era que cada um arcasse com as conseqüências de seus atos. Seria extrema falta de proceder, e portanto colocar-se à execração pública, deixar que outros apanhassem por culpa nossa" (p. 159).

${ }^{71}$ A idéia de que alguns aspectos da vida prisional devem permanecer velados, enquanto outros podem ser desvendados aos leitores de fora, inclui-se numa hierarquia própria à dinâmica prisional. Saber o que pode ser dito faz parte das disposições adquiridas pelos presos no processo de socialização naquele ambiente (para usar a idéia de Pierre Bourdieu) e determinará seu real pertencimento ao grupo. Quando, como fez Humberto Rodrigues ao revelar o significado das tatuagens dos detentos, esse pacto é rompido, compromete-se a lealdade (um valor caro) ao grupo. Por outro lado, quebrar esse laço pode marcar o limiar com o "além-grades", na tentativa de catapultar-se como autor.

72 "Para o internado, o sentido completo de estar 'dentro' não existe independentemente do sentido específico que para ele tem 'sair' ou 'ir para fora'. (...) [as instituições totais] Criam e mantêm um tipo específico de tensão entre o mundo doméstico e o mundo institucional, e usam essa tensão persistente como uma força estratégica no controle de homens" (Erving Goffman, Manicômios, prisões e conventos, pp. 23-24).
} 
sentido de injustiça comum e um sentido de amargura contra o mundo externo, o que assinala um movimento importante na carreira moral do internado"73.

O modo de sociabilidade precisa ser entendido, portanto, como um sistema que, mediado em texto, supõe o que chamei de olhar duplo, que ora se volta para dentro da prisão, ora para fora dela, mas muita vez para os dois a um só tempo (como em Memórias de um sobrevivente). Esse olhar duplo se constrói em diversas camadas.

A primeira delas é a própria situação da escrita: é preciso manter-se leal à conduta prisional (daí o caráter silencioso da narrativa em muitos momentos), mas não a ponto de tê-la como regra única - afinal, do reconhecimento, por parte de quem escreve a partir da prisão, da existência de uma normatividade além-muros prisionais é que depende a sua possibilidade de reinserção.

A segunda camada pode ser vista quando os narradores dos livros aqui discutidos relatam situações em que seguiram à risca o regrário do cárcere, mas o fazem de modo a sinalizar que reconhecem a burla aos preceitos do mundo exterior e, com isso, reivindicam o pertencimento a ele.

$\mathrm{Na}$ escolha das estruturas sintáticas (mais ou menos orais), do léxico (mais ou menos formal) e na necessidade de traduzir certos termos ou expressões, percebe-se um terceiro nível, mais propriamente ligado à forma, em que esses autores, a partir da introjeção do que seja uma boa escrita, revelam seu pertencimento e não pertencimento ao que, afinal, é uma condição circunstancial - a de encarcerado.

Finalmente, no tocante à materialidade do livro, vê-se, na maior parte dos volumes analisados, a inclusão de seções que criam uma espécie de padrão: agradecimentos, caderno de fotografias, reprodução de documentos. Aqui, parece estar em jogo a credibilidade da narrativa. Como se seus próprios autores partissem do pressuposto de que não seriam críveis, numa mobilização do estigma, a que já aludi a partir do livro homônimo de Goffman, a que estão expostos muitos daqueles cuja narrativa é de teor testemunhal. ${ }^{74}$

\footnotetext{
${ }^{73}$ Manicômios, prisões e conventos, p. 56.

${ }^{74}$ Como aponta Beatriz Sarlo em seu Tempo passado: cultura da memória e guinada subjetiva: "Todo testemunho quer ser acreditado, mas nem sempre traz em si mesmo as provas pelas quais se pode comprovar sua veracidade; elas devem vir de fora" (p. 37).
} 
No caso dos escritores saídos dos presídios paulistas, como já disse aqui, em sua grande maioria, provenientes das camadas mais pobres da população, a sua palavra já é duplamente desacreditada, pela origem e pelo delito cometido. A necessidade de ampararse de formas variadas, mas que remetem às estruturas jurídicas ${ }^{75}$, para poder ser lido pelos "não-iguais", disputa espaço com o compartilhamento do livro com o seu "grupo-deiguais" ${ }^{76}$ (outros detentos), mas também os amigos, vizinhos etc.

A título de exemplo, observe-se um trecho de Memórias de um sobrevivente: "Ali [na prisão] tudo era pagar. A semântica do verbo pagar era bastante interessante por ali. Tudo o que nos era fornecido pela cadeia trazia uma idéia de pagamento. A comida não era distribuída, era paga. 'Pagar um sapo' era fazer uma ameaça” (p. 414).

O comentário de Luiz Alberto Mendes é sobre a particularidade do uso de um determinado verbo dentro da cadeia. Ao fazê-lo, alterna dois registros facilmente identificáveis: um mais coloquial e impreciso ("ali tudo era pagar"); outro mais culto, em que alude a um termo de caráter técnico, ou científico, ou ainda lingüístico ("semântica"), e, em seguida, recorre a uma construção mais complexa como a voz passiva analítica ("tudo o que nos era fornecido pela cadeia"). $\mathrm{O}$ olhar do narrador, ao mesmo tempo em que revela sua proximidade com o mundo prisional (conhece suas gírias e o momento exato de empregá-las, a ponto de dissertar a respeito), distancia-se dele porque é capaz de assumir uma ótica que estranha o uso do verbo "pagar", o que não ocorreria se estivesse inteiramente absorvido pelo pólo prisional.

Nesse sentido, assume-se como um interno, mas, quando, ao fazê-lo, não deixa de estar referido aos padrões sintáticos e lexicais legitimados pelo mundo exterior, revela o caráter contingente de sua condição de encarcerado. A sua presença numa instituição total (e, como sugere Goffman, a própria existência da instituição total) só se dá como tal porque há a perspectiva de sair de lá. A literatura feita a partir do cárcere inscreve na sua construção a dinâmica relacional própria a uma instituição coercitiva ou, para retomar Foucault, "onidisciplinar"

\footnotetext{
${ }^{75}$ Observe-se, por exemplo, a indicação do número do prontuário (ver, especialmente, Vidas do Carandiru), a remissão às datas de prisão e soltura, a inclusão de fotos dentro do presídio (conferir Sobrevivente André Du Rap).

${ }^{76}$ A expressão é de Goffman. Ver Estigma, op. cit., p. 48.

${ }^{77}$ Vigiar e punir, p. 211. Ainda Foucault: "Esse 'reformatório' integral prescreve uma recodificação da existência bem diferente da pura privação jurídica de liberdade e (...) da simples mecânica de representações com que sonhavam os reformadores (...)" (idem, ibidem).
} 
Dessas escolhas derivaria uma construção destacada do personagem-narrador. Como procurei mostrar nos quatro primeiros capítulos, sobretudo nas análises de Memórias de um sobrevivente e de Vidas do Carandiru, na identificação de construção sintática, lexical e estilística de suas frases, já é possível notar a criação de uma "imagem de si”, mesmo quando não escreve explicitamente sobre $\mathrm{si}^{78}$. Quando a constroem, os escritores estudados revelam, por um lado, ter em conta uma expectativa de leitor ${ }^{79}$ que não os outros presos, uma vez que mobilizam, ao que parece, um conjunto de percepções referidas ao mundo exterior. São indícios de determinada apreensão do livro como objeto ${ }^{80}$. Aquilo que mobilizam, em função da incorporação do que seja o leitor externo à cadeia, pode contribuir para que o que ali se conta seja aceito como crível ${ }^{81}$. Assim como as práticas sociais se moldam, a escrita também o fará. Os livros de que trato articulam a imagem que têm de seus leitores e a imagem que seus leitores fazem de alguém que escreve a partir da prisão - ajustando-as a fim de produzir uma escrita que seja confiável e faça sentido a quem é de fora - à necessidade de não desfazer a imagem que seus autores sustentam entre os companheiros de prisão.

Por outro lado, como também já se discutiu aqui, esses autores não perdem a dimensão de que também escrevem para seus pares (embora em níveis variados: Diário de um detento e Sobrevivente André Du Rap trazem marcas mais claras disto), quando a sua

\footnotetext{
${ }^{78}$ Aproprio-me aqui do raciocínio de Ruth Amossy em "Da noção retórica de ethos à análise do discurso", p. 9.

${ }^{79}$ Não estou considerando, como sustentava H. R. Jauss, que "a história da literatura é um processo de recepção e produção estética que se realiza na atualização dos textos literários por parte do leitor que os recebe, do escritor, que se faz novamente produtor, e do crítico, que sobre eles reflete" ( $A$ história da literatura como provocação à teoria literária, p. 25), nem tampouco sugiro que o horizonte de expectativa (passível de reconstrução) de qualquer desses livros possa "determinar seu caráter artístico a partir do modo e do grau segundo o qual ela produz seu efeito sobre um suposto público" (idem, p. 31, grifos meus). Não há, ainda, como pretendia Jauss, posteridade a ser considerada (os livros todos são recentes, publicados nesta década), mas, sobretudo, neste trabalho não se dirá que a qualidade desses livros tem relação com o efeito produzido por cada um deles. No limite, é possível atribuir a este aspecto o interesse que despertam, mas não que venha daí o seu valor. Interessa aqui pensar o texto à luz das práticas sociais prisionais, que, justamente por envolverem o vislumbre de liberdade, têm no mundo exterior um eixo de construção. Interessa-me mais pensar numa formação social constritora que produz um discurso específico - ou, nas palavras de Chartier: "Numa formação como esta [sociedade de corte], a construção da identidade de cada indivíduo situa-se sempre no cruzamento da representação que ele dá de si mesmo e da credibilidade atribuída ou recusada pelos outros a essa representação" (Roger Chartier, op. cit., p. 112).

${ }^{80}$ Veja o que traz a esse respeito Vidas do Carandiru: "Acredito que consiga um livro de pelo menos 200 páginas" (p. 57) e "Meu avô, que era advogado e poliglota, sempre afirmava: livro que é livro tem que ter um número de páginas que proporcione a ele ficar em pé sozinho. E eu não posso decepcioná-lo" (p. 58).

81 "O orador adapta sua apresentação de si aos esquemas coletivos que ele crê interiorizados e valorizados por seu público-alvo" (Ruth Amossy, "O ethos na intersecção das disciplinas: retórica, pragmática, sociologia dos campos", p. 126).
} 
narrativa assume caráter exemplar, ou, ao menos, mostra-se leal às condutas e aos valores do cárcere, quando cede espaço a companheiros, quando faz questão de nomeá-los ou colocar seus retratos, quando cala a respeito de determinadas práticas, quando critica o sistema penitenciário e as más condições de cumprimento da pena, quando sustenta que para escrever sobre a cadeia é preciso ter estado lá ${ }^{82}$.

A escrita prisional assume uma dimensão ética quando se espera dela (e parece ser esta a aposta de seus autores) que transforme a percepção a respeito daquele que a produz e do ambiente de onde provém.

Um texto de teor autobiográfico ${ }^{83}$ como os quatro livros aqui analisados precisa construir uma elaboração da própria existência e trajetória em que é necessário determinar quais os eventos importantes, quais os comentários a incluir - disso resultando uma imagem a respeito de quem narra e é personagem daquela história. Constrangidas pela experiência prisional, de que precisam dar conta, que precisam narrar, essas histórias convergem em traço determinante, o do estigma - ou de uma escrita estigmatizada.

Em todos os textos analisados nesta tese aparece, de modo mais ou menos explícito, a questão do estigma que carrega um ex-presidiário.

Em Sobrevivente André Du Rap, está lá: “Antes de eu ser preso, eu era o André. Eu era o André que estudava, que trabalhava, eu tinha a minha família. À parte as intrigas de família, eu tinha uma família. A partir do momento em que eu fui preso, eu me tornei quem? Não o André, mas o bandido" (p. 106).

\footnotetext{
${ }^{82}$ Como já sugeri aqui, este aspecto não seria uma particularidade da escrita carcerária atual, mas já estaria presente, por exemplo, nas Memórias do cárcere, em que Graciliano Ramos assume a experiência como pré-requisito básico para tratar da cadeia.

${ }^{83}$ Uso a expressão "texto de teor autobiográfico" em função das superposições de gênero que existem na literatura feita a partir da prisão. Evidentemente, até mesmo aplicando-se os termos de Lejeune, há o "pacto autobiográfico", mas não é isso o que me interessa propriamente. Parte-se dele, mas se chega a questões mais relevantes para este trabalho: aceitando que se escreva partindo da experiência, como determinadas práticas sociais se tornam texto, são elaboradas numa escrita que deve servir para alçar seus autores à categoria de escritor (tirá-los da condição prisional), mas sem que abram mão dessa circunstância, porque é em função dela que almejam mudar sua situação. Ademais, uma das características da literatura produzida recentemente é a incorporação de elementos autobiográficos, em certa medida - porque o próprio ato da elaboração escrita assim o requer - ficcionalizando-os (haja vista, para permanecer na esfera nacional, o êxito de crítica obtido pelo último livro de Cristóvão Tezza, O filho eterno, e pelo romance de estréia de Tatiana Salem Levy, A chave de casa).
} 
Assim como no livro de Jocenir, quando o narrador, depois de ter sido maltratado pelo médico do presídio, se mostra surpreso ao ser atendido por outro médico, que lhe dedicou atenção:

"Ele [o médico] não rabiscava nada no papel, tinha a cabeça erguida, e me olhava com muita atenção. Senti um nó na garganta, me veio uma vontade de chorar. Sei que não é normal, era apenas uma consulta médica, mas ser bem tratado na cadeia por gente que não está presa é algo que não ocorre todos os dias, é diferente" ${ }^{84}$.

No caso de André, o que se vê é a elaboração da situação de estigmatizado, é a reflexão sobre o próprio estigma. No trecho de autoria de Jocenir, o estigma parece estar incorporado (presos não são bem tratados pelos não-presos) e o fato de aquele com quem fala tratá-lo como um igual é que o surpreende.

Será parecido o modo como Luiz Alberto Mendes dará conta da questão, que aparece com mais freqüência nas páginas finais de seu extenso livro, quando narra sua relação com a escrita e a leitura. Nesse sentido, pode parecer paradoxal, pois ao mesmo tempo em que sugere que nunca seria nada além de um preso, tem na publicação de seu livro por uma grande editora a prova contrária. Nas suas Memórias de um sobrevivente, quando menciona a paixão por Eneida, uma moça com quem se correspondia, já na fase em que abraçou a literatura, Mendes comenta:

"Quem era eu, afinal de contas, para ter uma Princesa que, além de tudo, estava comprometida? Se não fora pelo fato de ser casada, eu era um presidiário, um bandido, excluído da sociedade para sempre. Condenado a quase cem anos de prisão, na época, em treze processos por assalto, homicídio e latrocínio. (...) A mim só restavam as portas e grades fechadas. Por mais que estudasse e me transformasse, ainda assim seria um preso" ${ }^{" 15}$.

\footnotetext{
${ }^{84}$ Diário de um detento, p. 127.

${ }^{85}$ Memórias de um sobrevivente, pp. 462-462.
} 
"Por mais que estudasse e me transformasse" - quando Mendes insiste nessa idéia, amplia o alcance do êxito obtido. Com a publicação, sabe-se que estudou, que se transformou, que foi capaz de "mudar de vida". Daí o estigma poder ser manipulado por ele de modo a the render dividendos.

Finalmente, em Vidas do Carandiru:

"Muitos leitores poderão estar se perguntando: 'O que este expresidiário pretende, abordando temas de política socioeconômica de nosso país?'. É certo. Fui preso, condenado (sem ser ouvido!) e posteriormente absolvido pelo Tacrim. Muita gente não conseguiria passar por esse crivo. Lembro os nomes de alguns. Eu passei pelo crivo e, com a dor, a vergonha e o sofrimento, ganhei muito mais maturidade e consciência do sofrimento de nosso povo" (p. 265)

Rodrigues transforma o estigma ("este ex-presidiário") quando faz da sua superação uma prova de suas qualidades. É como se sugerisse que a passagem por uma situação inédita para alguém de sua classe e condição social o tornasse muito mais sensível para as questões sociais sobre as quais falava àquela altura do livro.

Indo um pouco além, vê-se que, nas formulações de Jocenir, André e Rodrigues, estão implícitas ou explícitas as marcas de interlocução. Na pergunta de André ("eu me tornei quem?”), de Rodrigues (“O que este ex-presidiário pretende, abordando temas de política socioeconômica de nosso país?”) e de Mendes (“Quem era eu, afinal de contas, para ter uma Princesa que, além de tudo, estava comprometida?"), no comentário de Jocenir - "Sei que não é normal [chorar em uma consulta médica]". Em todas elas, parece haver uma pressuposição de que o leitor os tem como presidiários: pessoas que delinqüiram, sem direitos, definitivamente marcadas.

Sem perder a noção, cara a Goffman, de que o estigma só existe porque há os não estigmatizados, não se pode esquecer também que:

"Nos muitos casos em que a estigmatização do indivíduo está associada com sua admissão a uma instituição de custódia, como uma prisão, um sanatório ou um orfanato, a maior parte do que ele aprende sobre o seu 
estigma ser-lhe-á transmitida durante o prolongado contato íntimo com aqueles que irão transformar-se em seus companheiros de infortúnio" ${ }^{\text {. }}$.

Nesse sentido, a incorporação do estigma é resultado das coerções, do confinamento, das más condições para cumprimento da pena. Ao elaborarem a condição estigmatizada, incorporando a projeção do que os leitores provavelmente pensariam a respeito daquele comentário, pretensão, expectativa, mostram reconhecer a existência da norma, a existência daquilo que não é visto como fonte de estigma - e mais uma vez elegem como parâmetro o mundo exterior.

Outra maneira, manifesta nos livros, para evitar o estigma é a relação com os sinais físicos, como as tatuagens. Rodrigues, na seção que dedica a explicá-las, pontua, excluindo-se: "Há uma coisa que os presos, em sua maioria, adoram. É o uso das tatuagens" $"$. Mendes tampouco as defende: "Os companheiros enchiam-se de grosseiras tatuagens. Jamais fizera alguma, não queria ficar marcado de modo algum"88. A essa altura da narrativa, a contrariedade que Mendes demonstra em relação às tatuagens tem razão de ser que não a que possivelmente assumiria mais tarde - tatuar-se era, então, contribuir para a identificação dos policiais, ao passo que, quando escreve a história, não carregar uma tatuagem no corpo ajuda a livrar-se do estigma de presidiário e, nesse sentido, o distingue, ao aproximá-lo do mundo dos homens "livres".

No entanto, há que se entender a tatuagem como sinal também ambivalente, porque constrói uma identidade prisional (sobretudo quando os desenhos são reveladores dos delitos cometidos), bem-vista entre os pares, mas também tomada com receio pelos de fora do mundo prisional ${ }^{89}$.

\footnotetext{
${ }^{86}$ E. Goffman, Estigma, op. cit., p. 46.

${ }^{87}$ Humberto Rodrigues, Vidas do Carandiru, op. cit., p. 291.

${ }^{88}$ Luiz Alberto Mendes, Memórias de um sobrevivente, op. cit., p. 189.

${ }^{89}$ Repare-se no comentário que Mendes faz quando conta que um preso, selecionado para uma sessão de tortura, prefere meter a cabeça na porta de ferro da cela a ser conduzido até os algozes: "Coisa dantesca, cena estarrecedora. Retiraram-no. Jamais soube do sujeito novamente, sumiu. Nunca mais esqueço aquela poça de sangue na entrada do xadrez, acho que está fotografada para o resto da vida, como uma tatuagem" (p. 301). Mendes serve-se da idéia da "tatuagem" para sugerir a sensação terrivelmente duradoura que lhe deixou a cena "suicida". Percebe-se assim algo que procurei discutir nos outros capítulos desta tese: o vocabulário com que se constrói a elaboração da experiência se impõe a partir da observação cotidiana e é referido ao dia-a-dia prisional.
} 
A relação que André Du Rap estabelece com as próprias tatuagens em tudo difere da de Mendes e de Rodrigues. Em muitas das fotografias em que André aparece, estão visíveis os desenhos que carrega no corpo. Mas é também André o único dos autores que exibe-se dentro da cadeia, tanto na foto da capa quanto naquelas que compõem um seu pequeno registro fotográfico. É como se, a exemplo do que faz pelas palavras ("mas eu não tenho vergonha de ser presidiário não, é a minha história”), quisesse pelas imagens mostrar que, sim, esteve preso (e as fotos no Carandiru o atestam), mas que tem também outras coisas a dizer, outras histórias a contar.

Os outros autores fazem um uso bastante mais comedido de sua imagem. Não há, por exemplo, sequer uma imagem de Mendes em seu livro, o único deles que não traz fotografias. Uma imagem de Rodrigues, por sua vez, é exibida na orelha de seu Vidas do Carandiru, mas ela rompe com qualquer noção pré-construída de um presidiário. Trata-se de um homem bem-vestido, com óculos nas mãos e, no fundo, cortinas de escritório, em ambiente claro, em tudo diferente do prisional. Posa qual o pesquisador que simula ser para sua própria salvação, na sua narrativa. O livro, embora contenha um caderno de fotos tomadas na prisão, não tem imagens suas naquele ambiente. A preocupação em distanciarse da prisão, uma constante na prosa de Rodrigues, como se viu no Capítulo 4, reaparece no cuidado em não se deixar marcar, não só por tatuagens, mas também pela ausência de fotografias. Mas, como até mesmo sobre sua palavra paira o descrédito, ele se ampara em fontes documentais que comprovem que ele esteve de fato na prisão - apenas o faz de modo a deixar clara a injustiça na sua detenção e julgamento e, por conseguinte, sustenta como a prisão era um ambiente estranho a quem vinha de seu estrato social.

Em Diário de um detento, como apontei no Capítulo 1, as poucas fotos (a da capa e a das páginas iniciais) não revelam o rosto de seu autor - em ambas repete-se uma mesma situação: um homem de costas amparado nas grades olhando para fora. Não há a imagem de Jocenir como havia a de André em Sobrevivente André Du Rap.

A relação com o estigma pode aparecer das mais diversas formas - na existência e decorrente arranjo de fotografias, na assunção da tatuagem como um fator de inclusão/exclusão. Ambas as situações repõem a marca, o sinal pelo qual alguém pode ser mais facilmente identificável como pertencente a um determinado grupo (aqui, o de 
presidiários). Se, por um lado, é confortável o próprio reconhecimento em um "grupo-deiguais", por outro, essa mesma identificação acarreta enormes prejuízos à imagem.

Nesse sentido, a incorporação do estigma e a necessidade de se livrar dele remontam ao olhar duplo, que ora aponta para dentro da cadeia, ora para fora dela.

Outra forma de lidar com o estigma é, como mostrei no Capítulo 1, pela assimilação do discurso produzido pelos não-presos. É comum os presos se chamarem de "ladrão", apelido dado pelos funcionários da Casa de Detenção $0^{90}$.

A esse comportamento Goffman deu o nome de "ambivalência de identidade":

"Quer mantenha uma aliança íntima com seus iguais ou não, o indivíduo estigmatizado pode mostrar uma ambivalência de identidade quando vê de perto que eles comportam-se de um modo estereotipado, exibindo de maneira extravagante ou desprezível os atributos negativos que lhes são imputados. Essa visão pode afastá-lo, já que, apesar de tudo, ele apóia as normas da sociedade mais ampla, mas a sua identificação social e psicológica com esses transgressores o mantém unido ao que repele, transformando a repulsa em vergonha e, posteriormente, convertendo a própria vergonha em algo de que se sente envergonhado. Em resumo, ele não pode nem aceitar o seu grupo, nem abandoná-10"91.

A maneira encontrada para lidar com o estigma é, como já se sustentou aqui, mostrar aptidões, além daquelas esperadas para alguém daquele grupo, como o aludido "dom da escrita". Mas, ao fazê-lo, esses autores correm o risco de distanciar-se em excesso dos seus pares, porque, afinal, estabelecem na escrita um sinal de distinção:

"O caráter que esses porta-vozes permitem ao indivíduo é gerado pela relação que ele tem com seus iguais. Se ele se volta para o seu grupo, é leal e autêntico; se se afasta dele, é covarde e insensato. (...) Ao chamar

\footnotetext{
${ }^{90}$ Para essa formulação, ver Elói Pietá e Justino Pereira. Pavilhão 9: o massacre do Carandiru, p. 17. Nos livros estudados, nota-se a incorporação: "Alguns presos estavam endividados. Droga. Resolveram me extorquir. Diziam que eu não era bandido, nem ladrão. Não era digno de viver entre eles" (Jocenir, Diário de um detento, p. 45). Ou: "Treta de ladrão é treta de ladrão", diz André, à página 18 de seu Sobrevivente André Du Rap.

${ }^{91}$ E. Goffman, Estigma, op. cit., p. 118.
} 
a atenção para a situação de seus iguais, ele está, de uma certa forma, consolidando uma imagem pública de sua diferença como uma coisa real e de seus companheiros estigmatizados como constituindo um grupo real. Por outro lado, se ele procura algum tipo de separação, e não de assimilação, pode descobrir que está necessariamente apresentando os seus esforços militantes na linguagem e no estilo de seus inimigos. (...) Os argumentos que apresenta, a situação que examina, as estratégias que defende são parte de um idioma de expressão e sentimento que pertence a toda a sociedade. Seu desdém por uma sociedade que o rejeita só pode ser entendido em termos da concepção que aquela sociedade tem de orgulho, dignidade $\mathrm{e}$ independência" ${ }^{92}$.

A noção de estigma, no que traz de relacional, contribui para a análise da literatura produzida a partir do cárcere porque repõe a ambivalência constitutiva dessas narrativas: a necessidade de reportar-se ao mundo exterior, ao reconhecer as suas condutas e valores (e só porque se almeja estar fora a cadeia pode existir), mas sem abandonar de vez o grupo a que pertence, os valores e as condutas que imperam na prisão.

A publicação do livro deve ser vista, portanto, como uma espécie de "investidura", para usar a nomenclatura de Bourdieu ${ }^{93}$. É quando aqueles homens são investidos da condição de autor, o que significa uma passagem de condição, ainda que o que suscite a obra seja a experiência estigmatizada, qual seja, a prisional. Mas até mesmo aqui é possível compreender essa produção por um viés dobrado: se no momento em que se tornam autores, chancelados por casas editoriais, por prefaciadores e por resenhas em jornais de grande circulação ${ }^{94}$, ganham evidente prestígio, não conseguem romper inteiramente com a pecha de autor-presidiário. A experiência do confinamento aprofunda esse jogo perverso de mercado porque é, como procurei mostrar, constritora.

\footnotetext{
92 Erving Goffman, Estigma, op. cit., pp. 124-125.

93 “A investidura (do cavaleiro, do deputado, do presidente da República etc.) consiste em sancionar e em santificar uma diferença (preexistente ou não) fazendo-a conhecer e reconhecer, fazendo-a existir enquanto diferença social, conhecida e reconhecida pelo agente investido e pelos demais" (Pierre Bourdieu, $A$ economia das trocas lingüisticas, p. 99)

${ }^{94}$ Ver Bibliografia.
} 
Embora este não seja assunto que apareça nos livros com freqüência, é importante lembrar que o estigma de presidiário, como mostra a grande bibliografia sobre o assunto, é definidor para que alguém que tenha estado preso não consiga um emprego, como aponta Carvalho Filho: "Cumprida a pena, o estigma da prisão acompanha e isola o condenado. Não há perspectiva visível de emprego (...). Quanto mais tempo atrás das grades, distante da dinâmica do mundo real, mais profunda a desadaptação e mais previsível o retorno à criminalidade" ${ }^{\circ 5}$.

Torna-se, assim, ainda mais notável que, na literatura produzida a partir da prisão, uma literatura que precisa ser lida como tentativa, por parte de seus autores, de reinserção ao mundo além-grades, o estigma seja explicitado e incorporado como seu traço definidor. Com isso, a literatura feita a partir da experiência prisional incorpora a própria imagem marcada, indicadora de uma série de características desabonadoras.

\section{II.}

Em 1970, Antonio Candido publicava seu "Dialética da malandragem", em que analisava a obra de Manuel Antonio de Almeida a partir do que chamou de dialética da ordem e da desordem. Em seu ensaio, questionava: "Qual a função exercida pela realidade social historicamente localizada para constituir a estrutura da obra?". Destacando um sistema de relações entre os personagens de Memórias de um sargento de milícias, chegava à constatação de que haveria ali "a construção, na sociedade descrita pelo livro, de uma ordem comunicando-se com uma desordem que a cerca de todos os lados" ${ }^{\prime 96}$ - e também detectava "sua correspondência profunda, muito mais que documentária, a certos aspectos assumidos pela relação entre a ordem e a desordem na sociedade brasileira da primeira metade do século XIX". Para, finalmente, pontuar: "embora elementares como concepção de vida e caracterização dos personagens, as Memórias são um livro agudo como percepção das relações humanas tomadas em conjunto. Se não teve consciência nítida, é fora de dúvida que o autor teve maestria suficiente para organizar um certo número de personagens segundo intuições adequadas da realidade social'"97.

\footnotetext{
${ }^{95}$ Luís Francisco Carvalho Filho, A prisão, p. 71.

${ }^{96}$ Antonio Candido, "Dialética da malandragem", p. 36.

${ }^{97}$ Idem, p. 37.
} 
Trinta e quatro anos mais tarde, em texto inicialmente publicado em jornal de grande circulação, João Cezar Castro Rocha propôs, em função do que identifica como uma necessidade histórica, uma reformulação da expressão consagrada por Antonio Candido $^{98}$. Sugeria que, no lugar da dialética proposta por Candido, estivesse surgindo uma "dialética da marginalidade". Segundo Castro Rocha, a mudança fazia-se necessária por conta da produção então recente, que, ao invés de conciliar conflitos, expunha-os. No rol de obras que pertenceriam a esse universo, incluía alguns livros produzidos a partir da prisão (ele cita o de André Du Rap, bem como Letras de liberdade), afirmando que, junto à música dos Racionais MCs, formavam uma "poética da sobrevivência", cujo "impulso principal era testemunhar a sobrevivência em meio a condições as mais adversas, fosse no cárcere, fosse na periferia".

Além de sinalizar certa tendência a reunir em uma mesma "poética" a produção vinda da periferia e a proveniente dos presídios, até certo ponto questionável pelas razões que exponho abaixo, o ensaio de Castro Rocha revia a formulação de Antonio Candido em função do seguinte: "A dialética da marginalidade (...) tem como alvo o dilema coletivo e se caracteriza por um esforço sério de interpretação dos mecanismos de exclusão social, pela primeira vez realizado pelos próprios excluídos", enquanto, segundo o autor, a dialética detectada por Candido em Memórias de um sargento de milícias escamotearia o conflito, por meio da figura do malandro, que pendia ora para a burla, ora para a norma.

Escritos (salvo raras exceções como a de Humberto Rodrigues) por moradores das periferias e favelas, os livros produzidos a partir do cárcere guardam certa semelhança com, como sugeria Castro Rocha, os livros de Ferréz, por exemplo, quando cedem espaço a companheiros, a quem agradecem e cujas fotos incorporam, quando assumem o discurso de denúncia às desigualdades sociais. Mas a parecença pára aí. A escrita do cárcere precisa ser pensada a partir do confinamento e de uma exclusão que é também espacial, segregadora em todas as instâncias. Exatamente por isso essa escrita se inscreve em uma dinâmica ainda semelhante à descrita por Antonio Candido. Afinal, Jocenir, André Du Rap, Luiz Alberto Mendes e Humberto Rodrigues têm a pretensão de ser absorvidos pelo que Antonio Candido chamava de pólo convencionalmente positivo, ainda que a pecha de "presidiários"

\footnotetext{
${ }^{98}$ João Cezar de Castro Rocha, "Dialética da marginalidade”, Mais!, Folha de S. Paulo, 29/02/2004.
} 
os mantenha naquilo que se poderia chamar de pólo negativo, para permanecer na nomenclatura proposta por Candido.

Ao contrário, no entanto, do que acontece ao final das Memórias de um sargento de milícias, nenhum desses narradores-personagens é de fato absorvido pelo pólo positivo, mas deixa entrever o seu desejo de o ser quando publica o livro (e o agradecimento presente em boa parte desses volumes o prova textualmente ${ }^{99}$ ), almeja a investidura de autor e o reconhecimento de sua transformação. Na expectativa de "absorção" reside talvez a maior dificuldade em considerar a produção do cárcere como característica do que Rocha chamou de dialética da marginalidade. Se não se negam a expor a própria situação, esses escritores não o fazem de modo a negar o "sistema" criticado - até porque a identidade prisional depende da perspectiva de estar fora, portanto, da perspectiva (nunca de fato completada) de ser absorvido pelo que Candido chama de "pólo convencionalmente positivo".

A dialética da marginalidade - quando enclausurada - repõe-se como dialética da ordem e da desordem, em prosa construída, aí, sim, pelos próprios presos.

Em artigo dedicado às narrativas do cárcere, Eneida Leal Cunha pontuava:

“(...) as narrativas que saem dos presídios, já nos títulos, afirmam sua a sua vontade forte de inclusão no sistema literário, através do apelo a formas instituídas - as memórias, o diário, o conto de vertente autobiográfica"100.

A vontade de inclusão no sistema literário a que se refere Cunha e já aqui repisada deve ser colocada talvez de outro modo: como narrativas produzidas em circunstâncias tão específicas se apropriam de "formas instituídas"?. O debate a respeito da apropriação de formas existentes remonta à constituição da visada sociológica na literatura brasileira. Quando Roberto Schwarz, referindo-se ao romance brasileiro do século XIX, declarou, em seu Ao vencedor as batatas, que "nossa imaginação fixara-se numa forma cujos

\footnotetext{
${ }^{99}$ A percepção do privilégio da publicação aparece em muitos dos textos na forma de interlocução: "Muito lhes agradeço a atenção dispensada", diz Luiz Alberto Mendes, à página final de seu livro; "Este livro é um sonho realizado. Obrigado por tê-lo lido", afirma Rodrigues, também nas últimas linhas de seu Vidas do Carandiru.

${ }^{100}$ Eneida Leal Cunha, "Margens e valor cultural”, p. 166.
} 
pressupostos, em razoável parte, não se encontravam no país, ou encontravam-se alterados"101, supôs que a forma-romance, burguesa por excelência, teoricamente não se prestasse à realidade escravocrata brasileira. Nesse sentido, haveria um descompasso entre forma e vida social - e a capacidade de evidenciar a tensão seria o momento de maior destaque das letras nacionais, com a publicação dos romances da segunda fase de Machado de Assis.

Já se disse aqui que, nos livros produzidos a partir do cárcere, a escrita é vista como meio de (re)inserção. Também já foi mencionado que esse movimento pela legitimação da escrita se constrói por um olhar que ora se volta para dentro da prisão, ora para fora dela. Ao fazê-lo, os autores mantêm-se leais aos companheiros de infortúnio, sem descuidar do leitor externo, porque se a legitimação pode ser dada em duas vias (pelos pares, que lidimam aquela narrativa, e pelos leitores externos, quando a publicam), a inserção no “mundo exterior” só pode ser dada por aqueles que não compartem o espaço prisional.

Decorre daí uma forma híbrida, que recorre a formatos vários e que remete, por um lado, ao precário letramento da população carcerária ${ }^{102}$ (quando um livro é visto como necessariamente extenso, quando há excesso de citações), por outro, à necessidade de validar, com os instrumentos reconhecidos, a própria palavra. Quando, no entanto, valendose dessa necessidade, superpõem diário, memórias, livros de citações, ditos bíblicos, além de lançarem mão das fotografias e reprodução de documentos, esses autores não deixam de sugerir uma forma própria - que, se estou certa, deve ser lida à luz de sua situação de produção, o cárcere.

Ao apontar para a incapacidade de organizar a própria história sem escapar à experiência prisional, os autores aqui estudados revelam certa insuficiência das formas reconhecidas e estabelecidas, ainda que recorram a elas ${ }^{103}$, de modo sobreposto, por necessidade de verem sua prosa e trajetória legitimadas.

A vida social na cadeia, como já sugeri no início deste capítulo, deve ser entendida como portadora de características próprias (ao ambiente de onde essa narrativa provém e

\footnotetext{
${ }^{101}$ Roberto Schwarz, Ao vencedor as batatas, p. 35 .

${ }^{102}$ De acordo com dados da Secretaria de Administração Penitenciária de São Paulo, em 2000, 75\% dos presos tinham apenas o ensino fundamental incompleto (http://www.sap.sp.gov.br/common/vinculados.html).

${ }^{103}$ Conforme Roger Chartier, “(...) não há produção cultural que não empregue materiais impostos pela tradição, pela autoridade ou pelo mercado e que não esteja submetida às vigilâncias e às censuras de quem tem poder sobre as palavras ou os gestos" (“Textos, impressos, leituras", p. 137).
} 
do qual essa prosa não escapa), os tais modos de sociabilidade do cárcere, mas são traços que só existem porque reportados a outros, os do mundo livre, "sem grades". Nesse sentido, a exposição dos conflitos (a denúncia de torturas, maus-tratos de toda ordem) vem acompanhada de desejo de cooptação por parte do mundo das letras, que não é reportado à prisão. A oscilação que há é entre a ordem prisional (a desordem?) e a ordem exterior à prisão (a ordem) - esse movimento pendular é, como procurei mostrar ao longo do trabalho, visto na interlocução, na forma narrativa e na disposição de elementos "extratextuais".

Portanto, por um lado, a escrita prisional reatualizaria uma dinâmica social, a que Paulo Arantes chamou de "dinâmica da combinatória brasileira" 104 e que remonta ao século XIX, remodelada, aqui, pela experiência prisional. Por outro, trata-se da primeira vez que surgem, efetivamente, escritores na prisão - o que embaralha os modelos interpretativos.

Ordem e desordem, no contexto da cadeia, precisam ser esmiuçadas: quando presos, os homens que antes infringiam a lei passam a seguir a lei da cadeia à risca. Quem não a segue, segundo as narrativas que compõem o corpus desta tese, não é digno de viver naquele ambiente. O cumprimento de um estrito código de conduta é necessário para ser admitido como um do grupo, o que, em ambiente de clausura, é fundamental. Organizamse para que se pautem todos por um conjunto de procedimentos - essa parece ser a ordem reinante entre os presos. Os presos procuram cumpri-la, porque correm o risco de ter decretada a pena capital se se insurgirem contra ela ou se não a reconhecerem como legítima. Os funcionários e a direção dos presídios se beneficiam dessa norma ditada e cobrada pelos detentos: é ela quem garante certo controle dos impulsos e, portanto, a relativa paz no cárcere.

No momento em que alguns presos resolvem contar a própria história, com o intuito de escrever um livro e publicá-lo, o mundo exterior ganha contornos mais nítidos do que os das visitas que recebem, do que o dos funcionários que trabalham no presídio ou dos juízes, psicólogos que definem seu destino. O mundo exterior à prisão passa a ser visto por quem escreve a partir da prisão como uma possibilidade de, a um só tempo, ter sua história ouvida e acreditada (o que não é pouco), e reinserir-se àquela sociedade sem que tenha de esconder a vida pregressa, quando, ao menos supostamente, infringiu as suas regras.

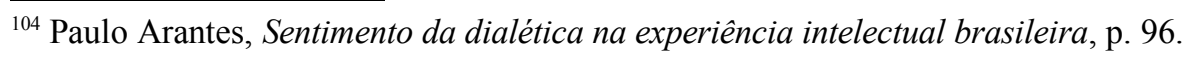


Quando a escrita-que-se-publica (é em tudo diferente da escrita das cartas, meio de comunicação bastante empregado nos presídios) é a forma escolhida para contar uma história que revela o seu autor como delinqüente, mas não apenas isso, o vislumbre de pertencimento ao "pólo positivo" (que, nas narrativas, é o equivalente a estar livre e tornarse escritor) reorienta a dialética da ordem e da desordem.

Agora, é preciso mostrar o conhecimento de normas mais específicas - literárias, gramaticais, estilísticas - para, enfim, postular uma futura e improvável inflexão na trajetória desordeira. Mas, como já muito se insistiu aqui, tendo que narrar a partir do cárcere (porque a experiência é tão aniquiladora quanto constritora), há de se respeitar certas condutas próprias àquele ambiente e não tão facilmente reconhecíveis por quem não está lá. Cria-se, portanto, a seguinte situação: o ambiente pouco cultivado das prisões brasileiras engendra livros que serão publicados por editoras reconhecidas. As histórias narradas nesses livros precisam, numa equação delicada, manter-se fiéis aos ditames do cárcere e acenar aos que estão fora dele para a possibilidade de transformação em sua carreira marginal. Mobilizam um mosaico de referências internas e externas à cadeia e o que resulta daí é algo que se destaca na produção cultural recente. 


\section{Anexo}

"Hoje estou aqui", de Antonio Donizetti

Preso como se fosse um bicho, sem ter ao menos o direito de me defender.

A carência e a solidão mexem com as minhas estruturas.

Estruturas essas que jamais pensei que um dia fossem ser abaladas.

Quem diria, heim?

Logo eu, um animal frio e calculista, capaz de planejar e arquitetar tudo o que eu possa um dia querer.

Mas a vida tem dessas coisas mesmo, são situações inexplicáveis, e com isso a gente nunca pára de aprender.

Hoje eu estou aqui...

Mas eu não deixo de sonhar um dia poder estar lá novamente.

Particularmente, não me iludo com a justiça.

Justiça esta que até o momento desconheço

Aqui é cobra engolindo cobra,

Até os veadinhos não escapam dessa corrupção.

Parece um pedágio de sobrevivência.

Hoje eu estou aqui...

Vendo e ouvindo, mas não posso fazer nada,

os meus filhotes estão lá fora.

Presos assim como eu, só que num mundo diferente.

Parceiro, o meu coração está todo riscado, sendo torturado pela solidão.

Para explicar é difícil, nem eu mesmo consigo, até eu às vezes fico perdido, é verdade.

A liberdade não se ganha, eu sei, se conquista!

Mas o que eu queria mesmo é ter uma pista de como chegar lá.

Mas é quase impossível neste lugar, porque tem muito "tamanduá".

Isso sem falar dos "piolhos" e percevejos, os mesmos dão um trabalho enorme aqui. 
Então o jogo de cintura tem de ser constante.

O inimigo está ao seu redor a todo instante, pronto para dar o bote.

Sem dó, sem pena.

Que pena! a "crocodilagem" predomina por aqui.

A carne humana é descartável.

Vejo camaleões camuflados, para que não sejam devorados também.

Hoje eu estou aqui...

Amanhã posso não estar, porque a patifaria é total.

E eu não sou nenhum Indiana Jones, Bradock ou Robocop.

Dentro do meu peito não existe aço.

Sou um animal, normal como todos os outros.

Indefeso, mas com um objetivo.

Objetivo este que poucos têm, e quem tem, guarda para si mesmo.

Poder olhar este mundo diferente, diferente como eu vejo todos os dias na televisão. Viver a vida.

E quando isso acontecer, o dia será curto.

Mas em compensação, a noite será longa.

Hoje eu estou aqui...

Vendo a imagem crítica deste lugar.

Vejo, com meus próprios olhos, lagartos e passarinhos e observo com atenção seus olhares assustados.

É simplesmente a imagem mais sincera que eu já vi.

Não quero nem procurar saber por que estão aqui.

Cada um, cada um...

Fiz de conta que nem os vi

Mas, para ser sincero, o engraçado aqui é ver um monte de leões assassinos fugindo de uma simples onça.

Por que será que os leões não enfrentam as onças?

Será que elas são mais perigosas do que eu?

Ou será simplesmente pelo fato de eles serem todos primogênitos? 
Ah, sei lá, deixa pra lá.

Hoje eu estou aqui...

Um dia, um companheiro disse-me aqui:

- Você agora está numa cadeia de segurança máxima.

No começo, não acreditei muito naquilo que meu amigo dizia.

Mas depois de engolir alguns sapos, comecei a acreditar.

Que lugar! Aqui os filhos choram e as mães não vêem.

São só lamentos, arrependimentos, mas que fazer?

É como eu já disse anteriormente:

eu vejo e ouço, mas infelizmente não posso fazer nada.

Cada um, cada um...

Fiz de conta que nem os vi.

Hoje eu estou aqui...

Com saudades das minhas gatinhas.

Saudades daqueles olhares ingênuos que me fascinavam.

É, na selva lá fora tem muito disso!

Algumas eu só aproveitei, outras só usei, você sabe como é.

Mas não consigo esquecer daquela que eu fiz mulher.

Agradeço muito pelos filhotes que me deu.

Talvez seja por isso que sobrevivo até hoje neste inferno.

Muitos não agüentaram, muitos correram,

muitos aqui não sobreviveram.

Mas graças a Deus estou de pé - Firme e forte!

Suando a minha camisa para um dia voltar para meus filhotes.

Simplesmente eles são a minha vida.

Vida esta que por aqui não vale nada.

Infelizmente esta é a linha

por onde tenho que fazer a minha caminhada.

Mas vou-que-vou, e com fé em Deus, eu ainda chego lá!

E quando isso acontecer, muitos carinhos vou lhe dar.

E se eu me sentir bem e gostar, 
pode ser quem for,

porque hoje estou aqui,

amanhã ao seu dispor. 


\section{Bibliografia}

\section{Livros da pesquisa:}

ANDRÉ DU RAP. Sobrevivente André du Rap (do Massacre do Carandiru). (coord. editorial Bruno Zeni). São Paulo, Labortexto Editorial, 2002

JOCENIR. Diário de um detento: o livro. São Paulo, Labortexto Editorial, 2001

MENDES, Luiz Alberto. Memórias de um sobrevivente. São Paulo, Companhia das Letras, 2001

RODRIGUES, Humberto. Vidas do Carandiru: histórias reais. São Paulo, Geração Editorial, 2002

Outros livros dos cárceres:

BISILliAT, Maureen (org.). Aqui dentro, páginas de uma memória: Carandiru. São Paulo, Imprensa Oficial do Estado de São Paulo/ Fundação Memorial da América Latina, 2003.

BUNKER, Edward. Educação de um bandido. São Paulo, Editora Barracuda, 2005.

DOSTOIÉVSKI, Fiodór M. Memórias da casa dos mortos. Rio, Nova Aguilar, 2004.

GENET, Jean. Diário de um ladrão. Rio de Janeiro, Nova Fronteira, 1983.

Letras da liberdade. São Paulo, WB Editores, 2000.

LIMA, William da Silva. Quatrocentos contra um: uma história do Comando Vermelho. São Paulo, Labortexto Editorial, 2001.

MENDES, Luiz Alberto. As cegas. São Paulo, Companhia das Letras, 2005. . Tesão e prazer: memórias eróticas de um prisioneiro. São Paulo, Geração Editorial, 2004.

NEGRINI, Pedro Paulo. Enjaulado: o amargo relato de um condenado pelo sistema penal. Rio de Janeiro, Gryphus, 2002.

PRADO, Antonio Carlos. Cela forte mulher. São Paulo, Labortexto Editorial, 2003.

RAMOS, Hosmany. Pavilhão 9: paixão e morte no Carandiru. São Paulo, Geração Editorial, 2001.

RAMOS, Graciliano. Memórias do cárcere. Rio de Janeiro/ São Paulo, Record, 2002.

VARELLA, Drauzio. Estação Carandiru. São Paulo, Companhia das Letras, 1999. 
WILDE, Oscar. A balada do cárcere de Reading. São Paulo, Nova Alexandria, 1997 (trad. e introd. Paulo Vizioli).

Bibliografia sobre os livros estudados:

ADORNO, Sérgio. "A ciência da tortura". Jornal de resenhas. São Paulo, Folha de S. Paulo, 12/02/2002.

CUNHA, Eneida. "Margens e valor cultural". In: Reinaldo Marques e Lúcia Helena Vilela (orgs.). Valores: arte, mercado, política. Belo Horizonte, Ed. UFMG/Abralic, 2002, pp. 159-169.

- "Narrar ou morrer (sobre vivências do sistema penitenciário brasileiro). Revista Semear 7, Rio de Janeiro, PUC-Rio, v. 1, 2002 (http://www.letras.pucrio.br/catedra/revista/7Sem_15.html)

HOSSNE, Andrea Saad. "Autores na prisão, presidiários autores. Anotações preliminares à análise de Memórias de um sobrevivente". Literatura e sociedade, São Paulo, Departamento de Teoria Literária e Literatura Comparada/ FFLCH/ USP, $n^{\circ}$ 8, 2005

MARQUES, Luciana Araújo. De dentro: escritos da periferia e da prisão. (Monografia de conclusão de curso). São Paulo, Faculdade Cásper Líbero, 2003.

MIRANDA, Ana. "Arte e crime em rota de convergência". Folha de S. Paulo, 17/03/2002.

PENNA, João Camillo. "Testemunhos da prisão: trauma, verdade jurídica e epitáfio". Letterature d'America. Ano XXVI, nos. 113-114, 2008, pp. 189-207.

SCHOLLHAMMER, Karl Erik. "Memórias de delinqüência e sobrevivência". In: K. E. Schollhammer e Heidrun Olinto (org.). Literatura e memória. Rio de Janeiro, Editora Galo Branco, 2006, pp. 137-147.

SCHWARTSMAN, Hélio. "Vidas do Carandiru: instantâneos expõem o sistema prisional brasileiro". Folha de S. Paulo, 21/12/2002.

SELIGMANN-SILVA, Márcio. "Novos escritos dos cárceres: uma análise de caso. Luiz Alberto Mendes, Memórias de um sobrevivente". Estudos de literatura brasileira contemporânea (“Literatura e testemunho"), n 27, Brasília, jan./jun. 2006, pp. $35-57$. 
. "Violência, encarceramento, (in)justiça: memórias de histórias reais das prisões paulistas". Revista de Letras, São Paulo, Unesp, v. 43, nº 2, jul./dez. 2003, pp. 29-47

TAUFER, Adauto Locatelli. Do factual ao ficcional: memória, história, ficção e autobiografia nas Memórias de um sobrevivente, de Luiz Alberto Mendes. (Dissertação de mestrado). Porto Alegre, UFRGS, 2007.

\section{Bibliografia Geral:}

ADORNO, Sérgio. "Sistema penitenciário no Brasil: problemas e desafios". Revista USP, n ${ }^{\circ}$, mar./abr./mai. 1991, pp. 65-78.

ADORNO, Theodor W. Notas de literatura I. São Paulo, Duas Cidades/ Ed. 34, 2003. - Autour de la Théorie Esthétique: Paralipomena, Introduction Première. Paris, Klincksieck, 1976. . "Crítica cultural e sociedade". In: Gabriel Cohn (org.) Sociologia. São

Paulo, Ática, s.d, pp. 76-91 . e HORKHEIMER, M. Dialética do esclarecimento: fragmentos filosóficos. Rio de Janeiro, Jorge Zahar Ed., 1985.

AMOSSY, Ruth. "Da noção retórica de ethos à análise do discurso"; "O ethos na intersecção das disciplinas: retórica, pragmática, sociologia dos campos”. In: R. A. (org.) Imagens de si no discurso: a construção do ethos. São Paulo, Contexto, 2005, pp. 9-28, 119-144.

ARANTES, Paulo Eduardo. Sentimento de dialética na experiência intelectual brasileira: dialética e dualidade segundo Antonio Candido e Roberto Schwarz. São Paulo/ Rio de Janeiro, Paz e Terra, 1992.

ARENDT, Hannah. Sobre a violência. Rio de Janeiro, Relume Dumará, 1994, pp. 13-30.

ARTIÈRES, Philippe. Le livre des vies coupables: autobiographies de criminels (1896-1909). Paris, Albin Michel, 2000.

ATHAYDE, Celso, MV Bill e Luiz Eduardo Soares. Cabeça de porco. Rio de Janeiro, Objetiva, 2005.

BARENGHI, Mario. "A memória da ofensa: recordar, narrar, compreender". Novos Estudos 73, novembro de 2005, pp. 175-191. 
BECKER, Howard S. "Biographie et mosaïque scientifique". Actes de la recherche en sciences sociales ("L'illusion biographique"). Paris, juin 1986, nº 62/63, pp. 3-29.

BENJAMIN, Walter. "Crítica da violência - crítica do poder". In: Documentos de cultura, documentos de barbárie (escritos escolhidos). São Paulo, Cultirx/ Edusp, 1986 pp. 160-175 (trad. Willi Bolle). . Magia e técnica: arte e política - ensaios sobre literatura e história da cultura. São Paulo, Brasiliense, 1994, vol. 1.

BOSI, Alfredo. Literatura e resistência. São Paulo. Companhia das Letras, 2002.

BOURDIEU, Pierre. "A ilusão biográfica”. In: Marieta de Moraes Ferreira \& Janaína Amado (orgs.). Usos e abusos da história oral. Rio de Janeiro, Ed. FGV, 2000, pp. 183-191 . A economia das trocas lingüisticas: o que falar quer dizer. São Paulo, Edusp, 1998 - "Campo do poder, campo intelectual e habitus de classe". In: $A$ economia das trocas simbólicas (introd., org. e seleção de Sergio Miceli). São Paulo, Perspectiva, 2003, pp. 183-202.

BROMBERT, Victor. La prison romantique: essai sur l'imaginaire. Paris, Librairie José Corti, 1975

CALDEIRA, Teresa Pires. "Violência, direitos e cidadania: relações paradoxais". Ciência e cultura, v. 54, $\mathrm{n}^{\circ} 1,2002$, pp. 43-46.

CANDIDO, Antonio. "Salinas no cárcere". In: Recortes. Rio de Janeiro, Ouro sobre azul, 2004, pp. 227-229.

. Literatura e Sociedade. São Paulo, T. A. Queiroz/ Publifolha, 2000

. "Dialética da malandragem". In: $O$ discurso e a cidade. São Paulo, Duas cidades, 1993, pp.19-54.

. “A verdade da repressão". Revista USP, nº 9, mar./abr./mai. 1991, pp. 27-30.

CARPEAUX, Otto Maria. “Pode um assassino escrever um bom poema?". In: Presenças. Rio de Janeiro, MEC/ Instituto Nacional do Livro, 1958, pp. 157-165. CARVALHO FILHO, Luís Francisco. A prisão. São Paulo, Publifolha, 2002. 
CASTRO, Myriam Mesquita Pugliese de. "Ciranda do medo: controle e dominação no cotidiano da prisão". Revista USP, nº 9, mar./abr./mai. 1991, pp. 57-64.

Catálogo de História Oral. Florianópolis, Universidade Federal de Santa Catarina (Curso de Pós-Graduação em História, Laboratório de História Oral), 1977.

CHARTIER, Roger. "Formação social e habitus: uma leitura de Norbert Elias"; "Textos, impressos, leituras". In: A história cultural: entre práticas e representações. Lisboa, Difel, 1990, pp. 91-119; 121-139.

CORTÁZAR, Julio. "Situação do romance". In: Valise de cronópio. São Paulo, Perspectiva, pp. 61-83.

DAMATTA, Roberto. "Pedro Malasartes e os paradoxos da malandragem". In: Carnavais, malandros e heróis: para uma sociologia do dilema brasileiro. Rio de Janeiro, Rocco, 1997, pp. 249-301.

DIAS, Ângela Maria. "Representações contemporâneas da crueldade: para pensar a cultura brasileira recente". In: Ângela M. Dias e Paula Glenadel (orgs.). Estéticas da crueldade. Rio de Janeiro, Atlântica Editora, 2004, pp. 15-23.

DUARTE, Rodrigo. "Expressão estética: conceitos e desdobramentos”. In: Rodrigo Duarte e Virgínia Figueiredo (orgs.). Mímesis e expressão. Belo Horizonte, Ed. UFMG, 2001, pp. 85-105.

EAGLETON, Terry. "De Adorno a Bourdieu”. In: Ideologia: uma introdução. São Paulo, Boitempo/ Editora da Unesp, 1997, pp. 115-142.

ELIAS, Norbert. “A individualização no processo social”. In: A sociedade dos indivíduos. Rio de Janeiro, Jorge Zahar Editor, 1994, pp. 102-125. - A sociedade de corte: investigação sobre a sociologia da realeza e da aristocracia de corte. Rio de Janeiro, Jorge Zahar Editor, 2001.

FABRIS, Mariarosaria. "Ramallah é aqui". Rodapé: crítica de literatura brasileira contemporânea. São Paulo, Nankin, agosto/2002, nº 2.

FEHÉR, Ferenc. O romance está morrendo?: contribuição à teoria do romance. Rio de Janeiro, Paz e Terra, 1997

FELMAN, Shoshana. "Educação e crise ou as vicissitudes do ensinar". In: Arthur Nestrovski e Márcio Seligmann-Silva (orgs.). Catástrofe e representação. São Paulo, Escuta, 2000, pp. 13-71. 
FERRÉZ. Capão Pecado. São Paulo, Labortexto Editorial, 2000. . Manual prático do ódio. Rio de Janeiro, Objetiva, 2003. . (org.) Literatura marginal: talentos da escrita periférica. Rio de Janeiro, Agir, 2005.

FOUCAULT, Michel. "Sobre a prisão". In: Microfisica do poder. Rio de Janeiro, Edições Graal, 1993 ( $1^{\text {a }}$ ed. 1979), pp. 129-143

. Vigiar e punir: nascimento da prisão. Petrópolis, Vozes, 1984. . "Teorias e instituições penais"; "A sociedade punitiva”. In: Resumo dos cursos do Collège de France 1970-1982. Rio de Janeiro, Jorge Zahar Editor, 1997, pp. 17-44.

. "O que é um autor?". In: O que é um autor? s.l., Passagens, 1997 - A ordem do discurso: aula inaugural no Collège de France, pronunciada em 2 de dezembro de 1970. São Paulo, Edições Loyola, 1996.

FREUD, Sigmund. O mal-estar na civilização. São Paulo, Imago, 1997.

GAGNEBIN, Jeanne-Marie. "Memória, história, testemunho". In: Stella Bresciani e Márcia Naxara (orgs.), Memória e (res)sentimento - indagações sobre uma questão sensivel. Campinas, Editora da Unicamp, 2001, pp. 85-94 . Lembrar escrever esquecer. São Paulo, Ed. 34, 2006.

GODARD, Henry. "La crise de la fiction: chroniques, roman-autobiographie, autofiction". In: Marc DAMBRE e Monique GOSSELIN-NOAT. L'éclatement des genres au XXème siècle, pp. 81-91.

GOFFMAN, Erving. Estigma: notas sobre a manipulação da identidade deteriorada. Rio de Janeiro, Guanabara Koogan, 1988. . Manicômios, prisões e conventos. São Paulo, Perspectiva, 1974

GONÇALVES, Márcia C. F. "A recusa da teoria da mímesis pelas teorias estéticas na virada dos séculos XVIII e XIX e suas conseqüências". In: Rodrigo Duarte e Virgínia Figueiredo (orgs.). Mímesis e expressão. Belo Horizonte, Ed. UFMG, 2001, pp. 289-297.

HADDAD, Galit. "Ethos prévio e ethos discursivo: o exemplo de Romain Rolland". In: Ruth Amossy (org.) Imagens de si no discurso: a construção do ethos. São Paulo, Contexto, 2005, pp. 145-165. 
HARDMAN, Francisco Foot. "Tróia de Taipa: Canudos e os irracionais". In: F. F. H. (org.). Morte e progresso: cultura brasileira como apagamento de rastros. São Paulo, Ed. Da Unesp, 1998, pp. 125-136.

HESSEN, Johannes. "O critério de verdade". In: Teoria do conhecimento. Coimbra, Arménio Amado, 1964, pp. 147-159.

JAUSS, Hans Robert. A história da literatura como provocação à teoria literária. São Paulo, Ática, 1994.

JAY, Martin. As idéias de Adorno. São Paulo, Cultrix/ Edusp, 1988.

KEHL, Maria Rita. “A fratria órfã”. In: Maria Rita Kehl (org.), Função fraterna. Rio de Janeiro, Relume Dumará, 2000, pp. 209-244.

. "O sexo, a morte, a mãe e o mal". In: Arthur Nestrovski e Márcio Seligmann-Silva (orgs.). Catástrofe e representação. São Paulo, Escuta, 2000, pp. 137-148.

LAQUEUR, Thomas W. "Corpos, detalhes e a narrativa humanitária”. In: Lynn Hunt (org.). A nova história cultural. São Paulo, Martins Fontes, 1995, pp. 239-277.

LEJEUNE, Philippe. Le pacte autobiographique. Paris, Éd. du Seuil, 1975.

LEVI, Giovanni. "Usos da biografia”. In: Marieta de Moraes Ferreira \& Janaína Amado (orgs.). Usos e abusos da história oral. Rio de Janeiro, Ed. FGV, 2000, pp. 167-182.

LEVI, Primo. É isto um homem? Rio de Janeiro, Rocco, 1988. Deber de memoria. Buenos Aires, Libros Del Zorzal, 2006

LUKÁCS, Georg. A teoria do romance: um ensaio histórico-filosófico sobre as formas da grande épica. São Paulo, Duas Cidades/ Ed. 34, 2000.

. "Narrar ou descrever". In: Ensaios sobre literatura. Rio de Janeiro, Civilização Brasileira, 1965, pp. 43-94.

MAAS, Wilma P. M. D. O cânone mínimo: o Bildungsroman na história da literatura. São Paulo. Ed. da Unesp. 2000.

MAINGUENEAU, Dominique. “Ethos, cenografia, incorporação”. In: Ruth Amossy (org.) Imagens de si no discurso: a construção do ethos. São Paulo, Contexto, 2005, pp. 69-92. . O contexto da obra literária. São Paulo, Martins Fontes, 1995. 
MARX, Karl. "Fundamentos da história"; "Fetichismo e reificacão". In: Octavio Ianni (org.) Karl Marx: sociologia. São Paulo, Ática, ano, pp. 45-61; 159-172.

MAUSS, Marcel. "Ensaio sobre a dádiva: forma e razão da troca nas sociedades arcaicas". In: Sociologia e antropologia. São Paulo, Cosac \& Naify, 2003, pp. 185-314.

MORINIÈRE, Thomas. "Les petites voies de la chanson de variétés: la révélation du charisme du chant et la démocratisation de la vocation d'interprète". Actes de la recherche en sciences sociales, $\mathrm{n}^{\circ} 168$, jun./2007, pp. 68-81.

PÉCORA, Alcir. "Querido sistema". Correio Popular, Campinas, 4/11/2000.

PENNA, João Camillo. "Este corpo, esta dor, esta fome: notas sobre o testemunho hispanoamericano". In: Márcio Seligmann-Silva (org.). História, Memória, Literatura: o testemunho na era das catástrofes. Campinas, Editora da Unicamp, 2003, pp. 299-354.

. "A língua do outro: o testemunho de Jacques Derrida". In: Rodrigo Duarte e Virgínia Figueiredo (orgs.). Mímesis e expressão. Belo Horizonte, Ed. UFMG, 2001, pp. 336-349. . "Marcinho VP (um estudo sobre a construção do personagem)". In: Ângela M. Dias e Paula Glenadel (orgs.). Estéticas da crueldade. Rio de Janeiro, Atlântica Editora, 2004, pp. 71-99.

PIETÁ, Elói e PEREIRA, Justino. Pavilhão 9: o massacre do Carandiru. São Paulo, Ed. Página Aberta, 1993.

PINHEIRO, Paulo Sérgio. "Autoritarismo e transição", Revista USP nº 9, mar./abr./mai. 1991, pp. $45-56$ (Dossiê Violência).

POLLAK, Michael e Nathalie Heinich. "Le témoignage", Actes de la recherche en sciences sociales ("L'illusion biographique"). Paris, juin 1986, no 62/63, pp. 3-29.

POUIVET, Roger. "L'épistémologie du témoignage et les vertus". Philosophie, no. 88, 1er décembre 2005. Paris, Minuit, pp. 11-27

RAMALHO, José Ricardo. Mundo do crime: a ordem pelo avesso. Rio de Janeiro, Edições Graal, 1979.

ROCHA, João Cezar de Castro. "Dialética da marginalidade: caracterização da cultura brasileira contemporânea". Folha de S. Paulo, 29/02/2004. 
ROSENFELD, Anatol. "A teoria dos gêneros". In: O teatro épico. São Paulo, Perspectiva, 2004, pp. 15-36.

. "Reflexões sobre o romance moderno". In: Texto/Contexto. São Paulo/Brasília, Perspectiva/Instituto Nacional do Livro, 1973, pp. 75-97

SAPIRO, Gisèle. "La vocation artistique entre don et don de soi"; “JJe n'ai jamais appris à écrire': les conditions de formation de la vocation d'écrivain". Actes de la recherche en sciences sociales, $\mathrm{n}^{\circ}$ 168, jun./2007, pp. 4-11; 12-33.

SARLO, Beatriz. Tempo passado: cultura da memória e guinada subjetiva. São Paulo/Belo Horizonte, Companhia das Letras/Editora da UFMG, 2007.

. "Cuando la política era joven". Punto de vista n ${ }^{\circ}$ 58, ago./1997, pp.

$15-19$.

SCHOLLHAMMER, Karl Erik. "Os cenários urbanos da violência na literatura brasileira". In: Carlos Alberto Messeder Pereira et al. (org.). Linguagens da violência. Rio de Janeiro, Rocco, 2000, pp. 236-259

SCHWARZ, Roberto. Seqüencias brasileiras. São Paulo, Companhia das Letras, 1999 . Um mestre na periferia do capitalismo: Machado de Assis. São Paulo, Duas Cidades/ Ed. 34, 2000. . Ao vencedor as batatas: forma literária e processo social nos inícios do romance brasileiro. São Paulo, Duas Cidades/ Ed. 34, 2000. . "Pressupostos, salvo engano, de 'Dialética da malandragem". In: Que horas são?: ensaios. São Paulo, Companhia das Letras, 1987, pp. 129-155. SELIGMANN-SILVA, Márcio. "Introdução"; "Apresentação da questão”. In: M. S. S. (org.). História, Memória, Literatura: o testemunho na era das catástrofes. Campinas, Editora da Unicamp, 2003, pp. 7-44; 45-58

. "A história como trauma". In: Arthur Nestrovski e Márcio SeligmannSilva (orgs.). Catástrofe e representação. São Paulo, Escuta, 2000, pp. 73-98. . "A catástrofe do cotidiano, a apocalíptica e a redentora: sobre Walter Benjamin e a escritura da memória”. In: Rodrigo Duarte e Regina Figueiredo (orgs.). Mímesis e representação. Belo Horizonte. Ed. UFMG, 2001, pp. 364-380. 
. "Do delicioso horror sublime ao abjeto e à escritura do corpo". In:

Ana Luiza Andrade et al. (org.). Leituras do ciclo. Florianópolis/ Chapecó, Abralic/ Editora Grifos, 1999, pp. 123-136.

- "As literaturas de testemunho e a tragédia: pensando algumas diferenças". In: Ettore Finazzi-Agrò e Roberto Vecchi (orgs.). Formas e mediações do trágico moderno: uma leitura do Brasil. São Paulo, Unimarco Editora, 2004, pp. $11-40$.

SOFIO, Sevérine. "La vocation como subversion: artistes femmes et anti-académisme dans la France révolutionnaire". Actes de la recherche en sciences sociales, $\mathrm{n}^{\circ} 168$, jun./ 2007, pp. 34-49.

SOUZA, Percival de. A prisão: história dos homens que vivem no maior presídio do mundo. São Paulo, Alfa-Ômega, 1977.

SÜSSEKIND, Flora. "Desterritorialização e forma literária: literatura brasileira contemporânea e experiência urbana". Revista do programa avançado de cultura contemporânea (http://acd.ufrj.br/pacc/z/ensaio/flora.htm).

VIALA, Alain. "A eloqüência galante: uma problemática da adesão". In: Ruth Amossy (org.) Imagens de si no discurso: a construção do ethos. São Paulo, Contexto, 2005, pp. 167-182.

WATT, Ian. "O realismo e a forma romance". In: A ascensão do romance: estudos sobre Defoe, Richardson e Fielding. São Paulo, Cia das Letras, 1996, pp. 11-33.

\section{Revistas}

Caros Amigos (Dossiê Literatura Marginal), ato I, ato III

Ocas: saindo das ruas. Ano 2, $\mathrm{n}^{\circ}$ 19, fevereiro/2004

Revista Cult 59. (Dossiê Vozes na prisão) julho/2002, pp. 34-44.

\section{Matérias de jornal}

"Ex-detento descreve em livro a rotina da violência". O Estado de S. Paulo, 21/02/2001 [a respeito do lançamento de Diário de um detento: o livro].

"Decidi fazer da experiência terrível algo bom". Folha de S. Paulo, 09/09/2002 [a respeito do lançamento de Sobrevivente André du Rap] 
"Sobrevivente relata massacre do Carandiru". Folha de S. Paulo, 09/09/2002 [a respeito do lançamento de Sobrevivente André du Rap]

"Livro reúne memórias de sobrevivente do Carandiru". O Estado de S. Paulo, 1\%10/2002 [a respeito do lançamento de Sobrevivente André du Rap]

"Ex-preso usa as próprias cicatrizes". Folha de S. Paulo, 20/08/2005 [a respeito do lançamento de Às cegas]. 